\author{
Н.Р. Кельчевская, С.А. Слукина, \\ И.С. Пелымская, Ф.В. Вольф
}

\title{
СОВЕРШЕНСТВОВАНИЕ СИСТЕМЫ УПРАВЛЕНИЯ БИЗНЕС-ПРОЦЕССАМИ СОЗДАНИЯ И ФУНКЦИОНИРОВАНИЯ МАЛОГО ИННОВАЦИОННОГО ПРЕДПРИЯТИЯ
}

монография

Natalya R. Kelchevskaya, Irina S. Pelymskaya, Svetlana A. Slukina, Fyodor V. Wolf

Improvement of the business process management system for the creation and operation of a small innovative enterprise

MOCKBA

КРЕАТИВНАЯ ЭКОНОМИКА

2019 
УДК 338.24

ББК 65.054

C56

\section{Рецензенты:}

Романова Ольга Александровна - доктор экономических наук, главный научный сотрудник отела региональной промышленной политики и экономической безопасности Института экономики УpO AH.

Исакова Наталья Юрьевна - кандидат экономических наук, доцент кафедры финансов, денежного обращения и кредита УрГЭУ СИНХ.

С56 Совершенствование системы управления бизнес-процессами создания и функционирования малого инновационного предприятия [Текст]: монография / Н.Р. Кельчевская, С.А. Слукина, И.С. Пелымская, Ф.В. Вольф. - М.: КРЕАТИВНАЯ ЭКОНОМИКА, 2019. $-212 \mathrm{c}$.

ISBN 978-5-91292-299-2

doi: $10.18334 / 9785912922992$

Монография посвящена совершенствованию организационно-методического обеспечения создания и управления бизнес-процессами малого инновационного предприятия.

Монография может быть полезна студентам, аспирантам, менеджерам, руководителям предприятий и практическим работниками в области управления бизнес-процессами малого инновационного предприятия.

ISBN 978-5-91292-299-2

(C) Кельчевская Н.Р., Слукина С.А., Пелымская И.С., Вольф Ф.В.,2019

(C) Оформление, дизайн обложки

ООО Издательство «Креативная экономика», 2019 


\section{ОГЛАВЛЕНИЕ}

ВВЕДЕНИЕ

9

ГЛАВА 1. ТЕОРЕТИЧЕСКИЕ И МЕТОДИЧЕСКИЕ ОСНОВЫ РЕАЛИЗАЦИИ ИННОВАЦИЙ В БИЗНЕСЕ

1.1. Содержание понятий «инновация» и «инновационная деятельность». Особенности функционирования инновационного

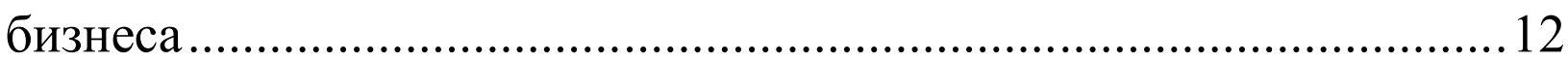

1.2. Малые инновационные предприятия.....................................223

ГЛАВА 2. АНАЛИЗ МАКРОЭКОНОМИЧЕСКИХ УСЛОВИЙ ФУНКЦИОНИРОВАНИЯ МАЛОГО ИННОВАЦИОННОГО БИЗ-

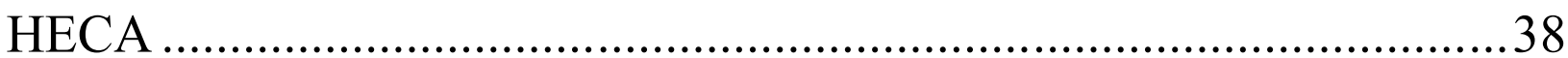

2.1. Экономико-правовая среда деятельности малых инновационных предприятий за рубежом .................................................... 38

2.2. Анализ условий ведения малого инновационного бизнеса в России: проблемы и перспективы.............................................. 48 ГЛАВА 3. ОРГАНИЗАЦИОННО-МЕТОДИЧЕСКОЕ ОБЕСПЕЧЕНИЕ СОЗДАНИЯ И ФУНКЦИОНИРОВАНИЯ МАЛОГО ИННОВАЦИОННО-ВНЕДРЕНЧЕСКОГО ПРЕДПРИЯТИЯ (НА ПРИМЕРЕ ПРЕДПРИЯТИЯ В СФЕРЕ СТОМАТОЛОГИИ)

3.1. Особенности ведения бизнеса и проблемы внедрения инноваций в сфере стоматологии 60

3.2. Элементы организационно-экономического механизма создания малого инновационно-внедренческого предприятия 66 3.3. Бизнес-процессы в деятельности малого инновационновнедренческого предприятия .77

3.4. Маркетинговый анализ целесообразности создания малого предприятия внедренческой направленности в стоматологии на базе существующей инновационной бизнес-идеи 90

3.5. Апробация организационно-экономического обеспечения создания малого инновационно-внедренческого предприятия в стоматологической сфере 
ГЛАВА 4. КОНЦЕПЦИЯ ТОТАL QUALITY MANAGEMENT (TQM) КАК ОСНОВА ЭФФЕКТИВНОЙ СИСТЕМЫ УПРАВЛЕНИЯ БИЗНЕС-ПРОЦЕССАМИ МАЛОГО ИННОВАЦИОННОГО ПРЕДПРИЯТИЯ.

4.1. Понятие качества. Природа качества.

4.2. Система всеобщего управления качеством

4.3. Инструменты управления качеством.

ГЛАВА 5. АНАЛИЗ ФУНКЦИОНИРОВАНИЯ СИСТЕМ УПРАВЛЕНИЯ КАЧЕСТВОМ. ОПЫТ ВНЕДРЕНИЯ. ПРИМЕНЯЕМЫЙ ИНСТРУМЕНТАРИЙ

5.1. Анализ мирового и российского опыта применения концепции TQM

5.2. Анализ зарубежного и российского опыта применения концепции Хосин-Канри 147

5.3. Взаимодействие инструментов в комплексе практического внедрения концепции ТQМ. 154 ГЛАВА 6. МЕТОДИЧЕСКИЙ ПОДХОД К УПРАВЛЕНИЮ БИЗНЕС-ПРОЦЕССАМИ НА МАЛОМ ИННОВАЦИОННОМ ПРЕДПРИЯТИИ НА ОСНОВЕ КОНЦЕПЦИИ ТQМ 165

6.1. Методическое обеспечение системы управления бизнеспроцессами на основе концепции ТQМ 165

6.2. Апробация методического обеспечения на предприятии 178 ЗАКЛЮЧЕНИЕ 195

БИБЛИОГРАФИЧЕСКИЙ СПИСОК 199 ПРИЛОЖЕНИЯ 207 
Монография посвящена совершенствованию организационнометодического обеспечения создания и управления бизнеспроцессами малого инновационного предприятия. Стремительный экономический рост, научные исследования в различных сферах экономической деятельности приводят к появлению принципиально новых инновационных технологий и продуктов.

Теоретическая и практическая значимость монографии заключается в расширении научных представлений об особенностях функционирования малого инновационно-внедренческого предприятия, развитии методических основ управления бизнес-процессами малого инновационного предприятии на основе концепции ТQM, что является значительным вкладом в развитие экономической науки.

Монография может быть полезна студентам, аспирантам, менеджерам, руководителям предприятий и практическим работниками в области управления бизнес-процессами малого инновационного предприятия.

Ключевые слова: бизнес-процессы, инновация, малое инновационно-внедренческое предприятие, модель управления, концепция TQM, эффективность. 


\section{Natalya R. Kelchevskaya, Irina S. Pelymskaya, Svetlana A. Slukina, Fyodor V. Wolf}

\section{IMPROVEMENT OF THE BUSINESS PROCESS MANAGEMENT SYSTEM FOR THE CREATION AND OPERATION OF A SMALL INNOVATIVE ENTERPRISE}

\section{CONTENT}

INTRODUCTION

CHAPTER 1. THEORETICAL AND METHODOLOGICAL BASIS OF INNOVATIONS IN BUSINESS

1.1. The content of the concepts "innovation" and "innovative activity". Particularities of innovative business .....................................................12

1.2. Small innovative enterprises 23

CHAPTER 2. THE ANALYSIS OF MACROECONOMIC CONDITIONS OF SMALL INNOVATIVE BUSINESS ........................38

2.1. Institutional environment of small innovative enterprises abroad ....38

2.2. The analysis of the conditions of small innovative business in Russia: problems and prospects 48

CHAPTER 3. ORGANIZATIONAL AND METHODOLOGICAL SUPPORT OF CREATION AND OPERATION OF A SMALL INNOVATIVE ENTERPRISE (ON THE EXAMPLE OF THE DENTAL FACILITY)

3.1. Particularities of doing business and problems of innovations in the dentistry

3.2. The elements of the organizational and economic mechanism for the creation of a small innovative enterprise .........................................66 3.3. Business processes in the activity of a small innovative enterprise....77 3.4. Marketing analysis of the practicality of a small dental innovative enterprise creation on the basis of the existing innovative business idea ....90 3.5. Approbation of organizational and economic support for the creation of a small dental innovative enterprise 
CHAPTER 4. THE CONCEPT OF TOTAL QUALITY MANAGEMENT (TQM) AS THE BASIS OF AN EFFECTIVE BUSINESS PROCESS MANAGEMENT SYSTEM OF A SMALL INNOVATIVE ENTERPRISE.

4.1. Concept of quality. Nature of quality

4.2. Universal quality management system

4.3. Quality management tools

CHAPTER 5. THE ANALYSIS OF THE QUALITY MANAGEMENT SYSTEMS PERFORMANCE. THE EXPERIENCE IN THE IMPLEMENTATION. THE APPLIED TOOLS

5.1. The analysis of world practices and Russian experience of the TQM concept application 142

5.2. The analysis of foreign and Russian experience in the application of the Hoshin Kanri concept

5.3. Interaction of tools in the complex of practical implementation of the TQM concept 154 CHAPTER 6. METHODOLOGICAL APPROACH TO BUSINESS PROCESS MANAGEMENT IN A SMALL INNOVATIVE ENTERPRISE BASED ON THE TQM CONCEPT .............................. 165 6.1. Methodological support of business process management system

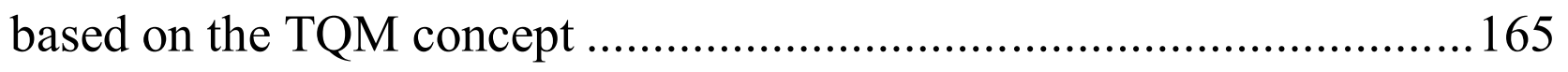
6.2. Approbation of the methodological support at the enterprise .........178

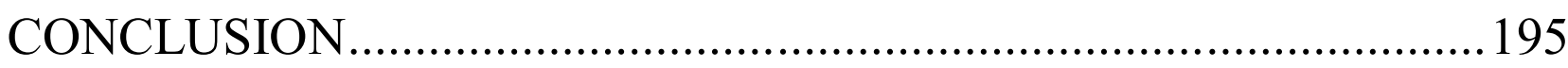

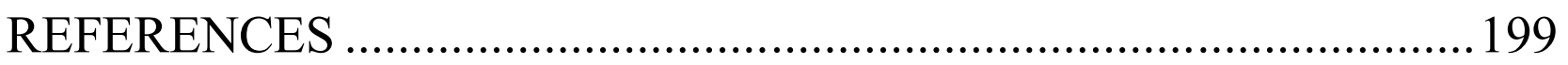

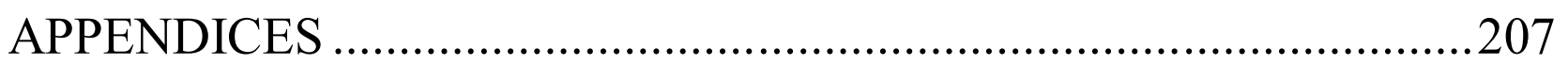


The monograph is devoted to the problem of improvement of the organizational and methodological support for the creation and management of business processes of a small innovative enterprise. Rapid economic growth and scientific researches in various economic activities lead to the appearance of the fundamentally new innovative technologies and products.

Theoretical and practical significance of the monograph includes the enlargement of the scientific notions about functioning of a small innovative enterprise and development of methodical bases of the business process management in small innovative enterprise based on the TQM concept, which is a significant contribution to the development of economic science.

The monograph might be useful to students, graduate students, managers, heads of enterprises and practitioners working in the business process management in small innovative enterprises.

Key words: business processes, innovation, small innovative enterprise, management model, TQM concept, efficiency 


\section{ВВЕДЕНИЕ}

Сегодня понятие инновации все чаще встречается в российском бизнесе. Стремительный экономический рост, не прекращающиеся исследования в различных видах экономической деятельности приводят к появлению инновационных принципиально новых технологий и продуктов. Инновационную деятельность осложняет то, что наукоемкий бизнес среди всех видов предпринимательства является наиболее сложным и наиболее рискованным.

Согласно докладу «Глобальный инновационный индекс» 2016 г., опубликованному Корнельским университетом, школой бизнеса INSEAD и Всемирной организацией интеллектуальной собственности (ВОИС), самый высокий глобальный инновационный индекс отмечен у таких стран, как Швейцария, Швеция, Соединенное Королевство и Соединенные Штаты Америки. Россия по показателю «Глобальный инновационный индекс» занимает лишь 43 место [1, с. 40]. Уровень инновационной активности в России в 2017 году по данным Росстата составил 8,4\% [2].

В настоящее время во всем мире выделен отдельный тип экономики - инновационный. Инновационная экономика (экономика знаний, интеллектуальная экономика) основана на потоке инноваций, на постоянном технологическом совершенствовании, на производстве и экспорте высокотехнологичной продукции с очень высокой добавочной стоимостью и самих технологий. Предполагается, что при этом в основном прибыль создаёт интеллект новаторов и учёных, информационная сфера, а не материальное производство (индустриальная экономика) и не концентрация финансов (капитала).

Некоторые исследователи (Э. Тоффлер, Ф. Фукуяма, Д. Белл, Дж. Нейсбитт и др.) считают, что для большинства развитых стран в современном мире именно инновационная экономика обеспечивает мировое экономическое превосходство страны, которая её создает $[3,4,5]$. 
В настоящее время в число стран с инновационной экономикой и развитым венчурным бизнесом, важнейшей составляющей инновационной экономики, входят США, Германия, Япония, Австралия, Канада, Швеция, Финляндия, Сингапур, Израиль и другие страны.

В России над теоретическими аспектами инноваций трудится ряд авторов. Тем не менее, они во многом цитируют западных ученых. Между тем, российская сфера экономики имеет свою специфику, в результате которой актуально разработать собственную модель внедрения инновационной деятельности. В литературе отсутствует систематизированное организационно-методическое обеспечение создания и функционирования малого инновационно-внедренческого предприятия.

Еще одной проблемой является выстраивание системы эффективного управления деятельностью таких малых инновационных предприятий.

Каждое предприятие, независимо от его масштаба и характера деятельности, не может обойтись без эффективного менеджмента. В начале XX века управление становится научным направлением, такого подхода требует укрупнение предприятий и изменение технологических процессов. Первые механизмы управления сразу показали свою эффективность, но со временем стали демонстрировать определенные недостатки и неспособность функционирования в новых условиях.

Во второй половине XX века Япония, освоив новые идеи менеджмента качества, благодаря усилиям доктора Э. Деминга и доктора Дж. Джурана, активно вышла на рынок с качественной и недорогой продукцией. Сами теории и концепции качества в результате их практического применения подверглись немалому изменению. Качество продукции стало конкурентным преимуществом. Это заставило пересмотреть основы менеджмента компаний. Высшее руководство компаний уже не могло просто делегировать одному под- 
разделению задачу обеспечения качества. Оно вынуждено было само возглавить работы по качеству, создавая специальные системы качества, вовлекать весь персонал компании в работы по качеству, обеспечивая при этом четкость и ясность в вопросах и прежде всего высшего менеджмента. К сожалению, российские предприятия в лице их руководителей и акционеров до сих пор не осознают в полной мере значимость перестройки существующей системы управления и внедрения систем менеджмента качества, ориентированных на TQM.

Качество выпускаемой продукции полностью зависит от участия высшего руководства компании в процессы совершенствования бизнес-процессов. Согласно исследованию профессора Э. Деминга, возникновение дефектов продукции или услуг - это проблема несовершенства управления организацией [6, с. 25]. По оценкам исследований в области совершенствования производственной деятельности, на 85-98\% от качества менеджмента зависит качество производимых товаров или услуг. Можно сделать вывод, что составляющими эффективного менеджмента являются грамотные управленческие решения, понимание компанией её целей и ценностей, а также постоянное системное совершенствование бизнес-процессов. Актуальность данной проблемы заключается в отсутствии системного подхода при формировании менеджмента компании. Отсутствие постоянства цели приводит к реорганизации процессов компании. Руководство не имеет представления, как оценить текущее состояние предприятия, возможные отклонения в бизнес-процессах. Оперативное реагирование на возникающие проблемы отсутствует, что приводит к возникновению новых дефектов.

Для осуществления эффективного менеджмента на инновационном предприятии необходима разработка методического обеспечения формирования бизнес-процессов в рамках системы управления качеством и ее внедрения на предприятии. Основой такого методического обеспечения может стать концепция TQM. 


\section{ГЛАВА 1. ТЕОРЕТИЧЕСКИЕ И МЕТОДИЧЕСКИЕ ОСНОВЫ РЕАЛИЗАЦИИ ИННОВАЦИЙ В БИЗНЕСЕ}

\section{1. Содержание понятий «инновация» и «инновационная деятельность». Особенности функционирования инновационного бизнеса}

В силу того, что инновации являются чрезвычайно сложным и многоаспектным феноменом человеческой жизнедеятельности, существует довольно много их различных трактовок и определений. Кроме этого, в настоящее время используется целый ряд терминов, которые по своей сути довольно близки по содержанию к понятию «инновация». Среди них «новшество», «нововведение», «новация» и пр.

Ряд авторов находит определенную специфику в этих терминах, в то время как другие используют их как синонимы. Но, учитывая тот факт, что в подавляющем большинстве случаев используется именно термин «инновация» и данное понятие является самым емким по содержанию, мы в дальнейшем будем использовать главным образом именно его [7]. Подробное изучение существующих определений понятия «инновация» показывает, насколько различный смысл вкладывают в этот термин авторы монографий, научных статей и учебных изданий. На отсутствие однозначности в определении инновации указывали в разное время Р.А. Фатхутдинов, В.Г. Медынский, В.И. Винокуров и другие авторы [8].

Й.А. Шумпетер - представитель австрийской школы, ввел в научный оборот термин «инновация» (от лат. innovatio - введение чего-либо нового) как новую экономическую категорию. Поэтому основой любых рассуждений относительно дефиниции «инновация» является классическое определение этого явления, предложенное данным автором. По мнению Й. Шумпетера, предметом инновации 
могут быть продукт, производственный процесс, а также организация, при условии, что они являются новыми и внедренными.

В табл. 1 представлены определения понятия «инновация».

Таблица 1

\section{Определения понятия «инновация»}

\begin{tabular}{|l|l|}
\hline \multicolumn{1}{|c|}{ Автор, источник } & \multicolumn{1}{|c|}{ Определение } \\
\hline \multicolumn{1}{|c|}{1} & \multicolumn{1}{|c|}{2} \\
\hline $\begin{array}{l}\text { Санто Б. Инновация как средство эконо- } \\
\text { мического развития, 1990, с. } 24\end{array}$ & $\begin{array}{l}\text { Инновация - это такой обществен- } \\
\text { ный, технический, экономический } \\
\text { процесс, который через практическое } \\
\text { использование идей и изобретений } \\
\text { приводит к созданию лучших по сво- } \\
\text { им свойствам изделий, технологий }\end{array}$ \\
\hline $\begin{array}{l}\text { Уткин Э.А., Морозова Н.И., Морозова Г.И. } \\
\text { Инновационный менеджмент, 1996, с. 10 }\end{array}$ & $\begin{array}{l}\text { Под инновацией (нововведением) } \\
\text { обычно подразумевается объект, вне- } \\
\text { дренный в производство в результате } \\
\text { проведенного исследования или сде- } \\
\text { ланного открытия, качественно от- } \\
\text { личный от предшествующего аналога }\end{array}$ \\
\hline $\begin{array}{l}\text { Суворова А.Л. Инновационный менедж- } \\
\text { мент, 1999, с. 15 }\end{array}$ & $\begin{array}{l}\text { Инновация - использование результа- } \\
\text { тов научных исследований и разрабо- } \\
\text { ток, направленных на совершенство- } \\
\text { вание процесса деятельности произ- } \\
\text { водства, экономических, правовых } \\
\text { и социальных отношений в области } \\
\text { науки, культуры, образования и дру- } \\
\text { гих сферах деятельности. }\end{array}$ \\
\hline $\begin{array}{l}\text { Под инновацией подразумевается } \\
\text { мент, 2002, с. 5 }\end{array}$ & $\begin{array}{l}\text { объект, внедренный в производство } \\
\text { в результате проведенного научного } \\
\text { исследования или сделанного откры- } \\
\text { тия, качественно отличный от пред- } \\
\text { шествующего аналога }\end{array}$ \\
\hline
\end{tabular}


Окончание табл. 1

\begin{tabular}{|c|c|}
\hline 1 & 2 \\
\hline $\begin{array}{l}\text { Кулагин А.С. Немного о термине «иннова- } \\
\text { ция», 2004, с. } 58 .\end{array}$ & $\begin{array}{l}\text { Инновация - новая или улучшенная } \\
\text { продукция (товар, работа, услуга), } \\
\text { способ (технология) ее производства } \\
\text { или применения, нововведение или } \\
\text { усовершенствование в сфере органи- } \\
\text { зации и (или) экономики производ- } \\
\text { ства и (или) реализации продукции, } \\
\text { обеспечивающие экономическую вы- } \\
\text { году, создающие условия для такой } \\
\text { выгоды или улучшающие потреби- } \\
\text { тельские свойства продукции (товара, } \\
\text { работы, услуги) }\end{array}$ \\
\hline $\begin{array}{l}\text { Фатхутдинов Р.А. Инновационный } \\
\text { неджмент, } 2005, \text { с. } 15\end{array}$ & $\begin{array}{l}\text { Инновация - это конечный результат } \\
\text { внедрения новшества с целью изме- } \\
\text { нения объекта управления и получе- } \\
\text { ния экономического, социального, } \\
\text { экологического, научно-технического } \\
\text { или другого вида эффекта }\end{array}$ \\
\hline $\begin{array}{l}\text { Райзберг Б.А., Лозовский Л.Ш., Старо- } \\
\text { дубцева Е.Б. Современный экономический } \\
\text { словарь, 1999, с. } 136\end{array}$ & $\begin{array}{l}\text { Инновация - нововведение в области } \\
\text { техники, технологии, организации } \\
\text { труда и управления, основанное на } \\
\text { использовании достижений науки } \\
\text { и передового опыта, а также исполь- } \\
\text { зование этих новшеств в самых раз- } \\
\text { ных областях и сферах деятельности }\end{array}$ \\
\hline
\end{tabular}

Прежде всего, различия в определениях инноваций связаны с различиями в понимании авторами предмета и объекта исследования. Так, В.Г. Медынский и др. указывают на то, что «в зависимости от объекта и предмета исследования инновации можно рассматривать: как процесс (Б. Твисс, А. Койре, И.П. Пинигс, В. Раппопорт, Б. Санто, В.С. Кабаков, Г.М. Гвишиани, В.Л. Макаров и др.); как систему (Н.И. Лапин, Й. Шумпетер и др.); как изменение (Ф. Валента, Ю.В. Яковец, Л. Водачек и др.); как результат (А. Левинсон, С.Д. Бешелев, Ф.Г. Гурвич и др.)» [9]. 
В своей статье «Понятие инноваций в современной экономической теории» Д.В. Гашко, резюмируя представленную выше классификацию, делит определения инновации на определения, понимающие под инновацией конечный результат некоторой деятельности, и определения, понимающие под инновацией некоторую деятельность, направленную на достижение определенного конечного результата [10]. На наш взгляд, это наиболее простая и при этом четко отражающая современную ситуацию классификация. Так, оценивая инновации как деятельность, «Рекомендации по сбору и анализу данных по инновациям» определяют инновации, как введение в употребление какого-либо нового или значительно улучшенного продукта (товара или услуги) или процесса, нового метода маркетинга или нового организационного метода в деловой практике, организации рабочих мест или внешних связях [11].

Согласно же Федеральному закону РФ «О внесении изменений в Федеральный закон «О науке и государственной научно-технической политике» N 254-Ф3 от 21 июля 2011 года, инновация рассматривается как результат деятельности - это введённый в употребление новый или значительно улучшенный продукт (товар, услуга) или процесс, новый метод продаж или новый организационный метод в деловой практике, организации рабочих мест или во внешних связях. В настоящее время применительно к технологическим инновациям действуют понятия, установленные в Международных стандартах в статистике науки, техники и инноваций. Международные стандарты в статистике науки, техники и инноваций - рекомендации международных организаций в области статистики науки и инноваций, обеспечивающие их системное описание в условиях рыночной экономики.

В соответствии с этими стандартами инновация - конечный результат инновационной деятельности, получивший воплощение в виде нового или усовершенствованного продукта, внедренного на 
рынке, нового или усовершенствованного технологического процесса, используемого в практической деятельности, либо в новом подходе к социальным услугам [12]. Данное определение мы и будем использовать в представленной работе.

Понятие инновация относится как к радикальным, так и постепенным (инкрементальным) изменениям в продуктах, процессах и стратегии организации (инновационная деятельность). Исходя из того, что целью нововведений является повышение эффективности, экономичности, качества жизни, удовлетворённости клиентов организации, понятие инновационности можно связать с понятием предприимчивости - восприимчивости к новым возможностям улучшения работы организации (коммерческой, государственной, благотворительной, морально-этической). «Новизна» инноваций оценивается по технологическим параметрам, а также с рыночных позиций. Сегодня описание технологических инноваций базируется на международных стандартах, рекомендации по которым были приняты в г. Осло в 1992 г. (так называемое «Руководство Осло»). Эти стандарты охватывают новые продукты и новые процессы, а также их значительные технологические изменения [11].

С термином «инновация» тесно связаны понятия «изобретение» и «открытие». Под изобретением понимают новые приборы, механизмы, инструмент, созданные человеком. Под открытием подразумевают процесс получения ранее неизвестных данных или наблюдение ранее неизвестного явления природы. В отличие от инновации, открытие делается, как правило, на фундаментальном уровне и не преследует целью получить выгоду.

Инновация - это такой процесс или результат процесса, в котором:

- используются частично или полностью охраноспособные результаты интеллектуальной деятельности; 
- обеспечивается выпуск патентоспособной продукции;

- обеспечивается выпуск товаров и/или услуг, по своему качеству соответствующих мировому уровню или превышающих его;

- достигается высокая экономическая эффективность в производстве или потреблении продукта.

Деление инноваций на конкретные группы по определенным признакам называют классификацией инноваций. В практике управления инновациями используют различные классификаторы инноваций. В зависимости от технологических параметров инновации подразделяются на продуктовые и процессные. Продуктовые инновации включают применение новых материалов, новых полуфабрикатов и комплектующих; получение принципиально новых продуктов. Процессные инновации означают новые методы организации производства (новые технологии).

По типу новизны для рынка инновации делятся на: новые для сферы экономической деятельности в мире; новые для сферы в стране; новые для данного предприятия (группы предприятий).

По стимулу появления (источнику) можно выделить:

- инновации, вызванные развитием науки и техники;

- инновации, вызванные потребностями производства;

- инновации, вызванные потребностями рынка.

По месту в системе (на предприятии, в фирме) можно выделить:

- инновации на входе предприятия (сырье, оборудование, информация и др.);

- инновации на выходе предприятия (изделия, услуги, технологии, информация и др.);

- инновации системной структуры предприятия (управленческой, производственной). 
В зависимости от глубины вносимых изменений выделяют: радикальные (базисные) инновации, которые реализуют крупные изобретения и формируют новые направления в развитии техники; улучшающие инновации, которые реализуют мелкие изобретения и преобладают на фазах распространения и стабильного развития научно-технического цикла; модификационные (частные) инновации, направленные на частичное улучшение устаревших поколений техники и технологии.

С понятием «инновации» тесно связано понятие «инновационная деятельность», также достаточно полно и глубоко исследованное в литературе, посвященной проблемам реализации инноваций.

Инновационная деятельность - это деятельность, направленная на поиск и реализацию инноваций в целях расширения ассортимента и повышения качества продукции, совершенствования технологии и организации производства. Главная предпосылка инновационной деятельности предприятия состоит в том, что все существующее стареет. Поэтому необходимо систематически отбрасывать все то, что износилось, устарело, стало тормозом на пути к прогрессу, а также учитывать ошибки, неудачи и просчеты. Для этого на предприятиях периодически необходимо проводить аттестацию продуктов, технологий и рабочих мест, анализировать рынок и каналы распределения.

Иными словами, должна проводиться своеобразная рентгенограмма всех сторон деятельности предприятия. Это не просто диагностика производственно-хозяйственной деятельности предприятия, его продукции, рынков и т.д. На ее основе руководители должны первыми подумать о том, как самим сделать свою продукцию (услуги) морально устаревшей, а не ждать, пока это сделают конкуренты. А это, в свою очередь, будет побуждать предприятия к инновациям. Практика показывает: ничто так не заставляет руководителя сосредоточиться на инновационной идее, как осознание того, что 
производимый продукт уже в ближайшем будущем окажется устаревшим [12].

Основные виды инновационной деятельности:

- подготовка и организация производства, охватывающие приобретение производственного оборудования и инструмента, изменения в них, а также в процедурах, методах и стандартах производства и контроля качества, необходимых для создания нового технологического процесса;

- предварительные производственные разработки, включающие модификации продукта и технологического процесса, переподготовку персонала для применения новых технологий и оборудования;

- маркетинг новых продуктов, предусматривающий виды деятельности, связанные с выпуском новой продукции на рынок, включая предварительное исследование рынка, адаптацию продукта к различным рынкам, рекламную кампанию;

- приобретение технологии со стороны в форме патентов, лицензий, ноу-хау, торговых марок, конструкций, моделей и услуг технологического содержания;

- приобретение овеществлённой технологии - машин и оборудования, по своему технологическому содержанию связанных с внедрением на инновационное предприятие продуктовых или процессных инноваций;

- производственное проектирование, включающее подготовку планов и чертежей для определения производственных процедур, технических спецификаций.

Инновационная деятельность выполняет следующие три функции:

- воспроизводственную; 
- инвестиционную;

- стимулирующую.

Воспроизводственная функция означает, что инновация представляет собой важный источник финансирования расширенного воспроизводства. Смысл воспроизводственной функции состоит в получении прибыли от инновации и использовании ее в качестве источника финансовых ресурсов.

Прибыль, полученная за счет реализации инновации, может использоваться по различным направлениям, в том числе и в качестве капитала. Этот капитал может направляться на финансирование новых видов инноваций. Таким образом, использование прибыли от инновации для инвестирования составляет содержание инвестиционной функции инновации. Получение предпринимателем прибыли за счет реализации инновации прямо соответствует основной цели любой коммерческой организации. Прибыль служит стимулом для предпринимателя для внедрения новых инноваций; побуждает его постоянно изучать спрос, совершенствовать организацию маркетинговой деятельности, применять современные методы управления финансами. Все вместе это составляет содержание стимулирующей функции инновации [13]. Инновационная деятельность или инновационный процесс, включает в себя восемь элементов, соединение которых в единую последовательную цепочку образует структуру инновационного процесса (рис. 1). А.Н. Цветков в 1997 г. выделил более подробную структуру инновационного процесса, представленную на рис. 2.

Началом инновационного процесса является инициация. Инициация - это деятельность, состоящая в выборе цели инновации, постановке задачи, выполняемой инновацией, поиске идеи инновации, ее технико-экономическом обосновании и в материализации идеи. Материализация идеи означает превращение идеи в товар. 


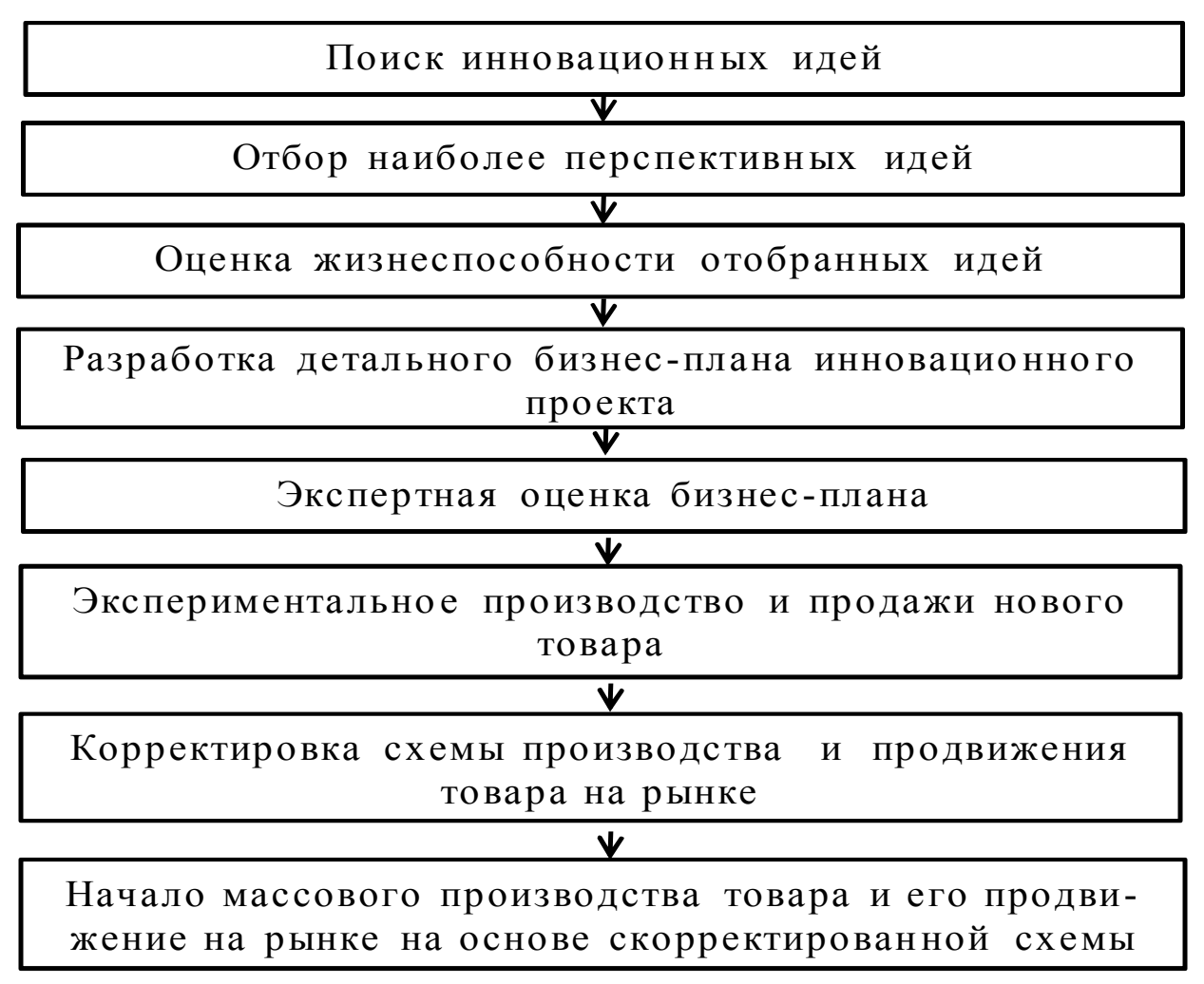

Рис. 1. Основные этапы инновационной деятельности [14]

После обоснования нового продукта проводятся маркетинговые исследования предлагаемой инновации, в ходе которых изучается спрос на новый продукт, определяется объем выпуска продукта, определяются потребительские свойства и товарные характеристики, которые следует придать инновации как товару, выходящему на рынок. Затем производится продажа инновации, то есть появление на рынке небольшой партии инновации, ее продвижение, оценка эффективности и диффузия. Продвижение инновации представляет собой комплекс мер, направленных на реализацию инноваций (реклама, организация процесса торговли и др.). Результаты реализации инновации и затраты на ее продвижение подвергаются статистической обработке и анализу, на основании чего рассчитывается экономическая эффективность инновации. Инновационный процесс заканчивается диффузией инновации. Диффузия (лат. diffusio - pacпространение, растекание) инновации, представляет собой распространение однажды освоенной инновации в новых регионах, на новых рынках [16, с. 49]. 


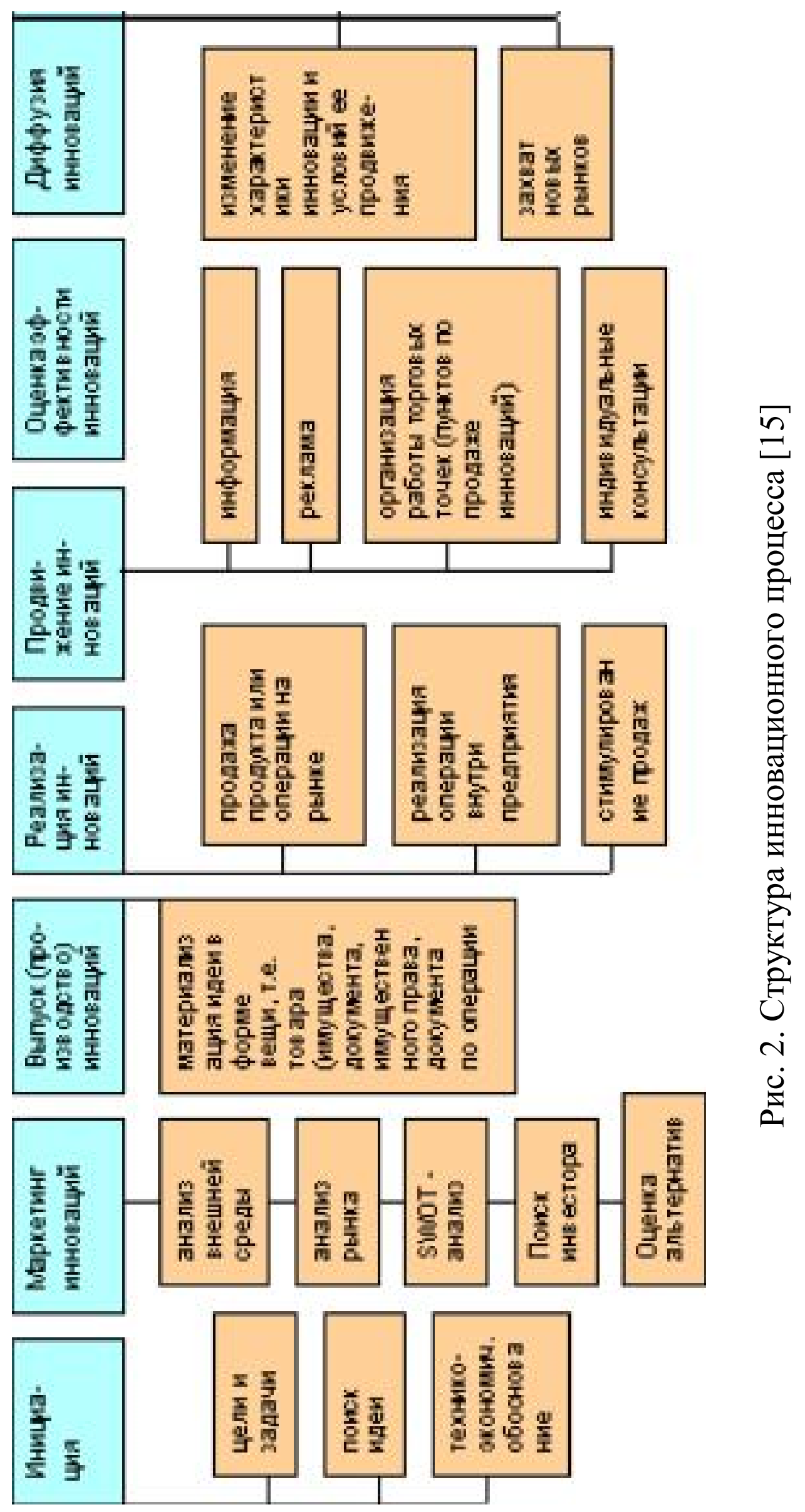




\section{2. Малые инновационные предприятия}

Малое предприятие - это организация, которая попадает под критерии определенные в законе «О развитии малого и среднего предпринимательства в Российской Федерации» [17]. К субъектам малого предпринимательства может быть отнесена любая организация, если она отвечает следующим критериям:

- суммарная доля участия в уставном капитале организации РФ, субъектов РФ, муниципальных образований, общественных, религиозных организаций, фондов не более $25 \%$;

- суммарная доля участия в уставном капитале организации иностранных организаций не более $49 \%$;

- суммарная доля участия в уставном капитале организации других организаций, не являющихся субъектами малого и среднего предпринимательства не более $49 \%$;

- средняя численность работников за предшествующий календарный год не более 100 человек;

- выручка от реализации товаров (работ, услуг) без учета НДС за предшествующий календарный год не более 800 млн руб.

Организация утратит статус субъекта малого предпринимательства, если будет превышено предельное значение:

- критерия 1, 2 или 3 - с даты, когда изменение долей в уставном капитале будет зарегистрировано в ЕГРЮЛ;

- критерия 4 или 5 в течение трех календарных лет подряд - по истечении этих трех лет, т.е. на четвертый год [17].

В 1991 г. Европейским Союзом была разработана программа TACIS (Technical Assistance for the Commonwealth of Independent States, Техническая помощь Содружеству Независимых Государств (CHГ)). Программа TACIS до 2006 года помогала разным государст- 
вам, включая РФ, в разных направлениях деятельности. Один из таких направлений было предоставление грантов на предоставление ноу-хау странам СНГ. В соответствии с правовым актов ЕС, программа TACIS определяла собственные критерии малых инновационных предприятий:

- производимая доля продукции старше трех лет не более 10\%;

- затраты на НИОКР не менее $10 \%$ в год от всех расходов предприятия;

- отгруженная доля готовой инновационной продукции не менее $30 \%$ за год.

Организации - субъекты малого предпринимательства могут вести упрощенный бухучет и составлять упрощенную бухгалтерскую отчетность, в том числе упрощенный бухгалтерский баланс и упрощенный отчет о финансовых результатах. Также малые предприятия вправе не устанавливать лимит остатка по кассе. То есть они могут накапливать деньги у себя в кассе столько, сколько захотят. Предпринимательство, предпринимательская деятельность рисковая экономическая деятельность, направленная на систематическое получение прибыли от производства и продажи товаров, оказания услуг, выполнения работ. Особое значение для понимания сущности предпринимательства имеет точка зрения американских экономистов К.Р. Макконнелла и С.Л. Брю, которые выделили четыре взаимосвязанные функции предпринимателя:

- предприниматель берет на себя инициативу соединения ресурсов - земли, капитала и труда - в единый процесс производства товаров и услуг;

- предприниматель берет на себя разработку и принятие основных решений в процессе ведения бизнеса, т.е. тех операций, которые и определяют курс деятельности предприятия, направления развития бизнеса: 
- предприниматель - это новатор, лицо, стремящееся производить новые продукты (услуги), разрабатывать новые производственные технологии или вводить новые формы организации и развития бизнеса:

- предприниматель берет на себя риск, возникающий при осуществлении предпринимательской деятельности, гак как получение прибыли для предпринимателя не гарантировано, вознаграждением за затраченное время, усилия и способности могут быть как прибыль, так и убытки. При этом предприниматель рискует не только своим временем, трудом и деловой репутацией, но и вложенными денежными средствами.

Под инновационным предпринимательством, в широком смысле, понимается процесс создания и использования в коммерческих целях технико-технологических нововведений. В основной массе инновационная предпринимательская деятельность базируется на нововведениях в сфере продукции, работ и услуг, позволяющих сформировать качественно иной рынок, содействовать удовлетворению новых, пусть даже неординарных, общественных потребностей. Инновации в данном случае служат специфическим инструментом предпринимательства. При этом стоит отметить, что не инновации как таковые являются предпринимательским инструментом, а именно направленный организованный поиск новшеств, постоянная нацеленность на них предпринимательских структур [18].

В современной литературе экономического содержания речь ведется о трех основных видах предпринимательства в инновационной сфере:

- инновационная продукция, в целях создания которой требуется постоянное и качественно новое обновление рынков сбыта выпускаемой предприятием продукции, обеспечение достаточных условий выживаемости предприятия, наращивание объемов образуемой прибыли, расширение рыночного сегмента, эффективное со- 
трудничество с уже существующей клиентурой, укрепление независимости и престижа предприятия, формирование новых рабочих мест;

- инновационные технологии, в целях эффективного использования которых требуется постоянное обновление производственного потенциала предприятия, ориентированное на увеличение производительности труда и экономичность энергетических, сырьевых и прочих ресурсов. Применение инноваций технологий предоставляет возможности увеличения объемов прибыли предприятия, совершенствование техники безопасности труда работников предприятия, проведение мероприятий по защите экологии, эффективное использование внутрифирменных информационных систем;

- социальные инновации, предполагающие планомерное улучшение социума фирмы. Использование социоинноваций дает возможность вести эффективный поиск рабочей силы на рынке, ориентировать коллектив фирмы на решение поставленных задач, укреплять доверительные отношения между сотрудниками и руководством предприятия.

Как известно, в общем случае предпринимательская деятельность проходит четыре стадии:

- активный поиск новых идей и анализ степени их реализуемости;

- формирование бизнес-плана;

- активный поиск требуемых ресурсов;

- формирование механизма управления новой фирмой.

Инновационное предпринимательство предполагает более подробное этапирование:

- разработка комплекса инновационных идей; 
- выборка более перспективной идеи;

- подробная проработка вложенного смысла и экспертная его оценка;

- детальная проработка бизнес-плана;

- экспертиза бизнес-плана;

- эксперимент по производству продукции и ее испытание в рыночных условиях;

- внесение корректив в схему производства и реализации продукции в условиях рынка;

- массированное производство инновационной продукции и ее продвижение на рынок.

В зависимости от способа организации и ведения инновационного процесса на предприятии целесообразно обозначить следующие модели инновационного предпринимательства:

- предпринимательство в сфере инноваций, основанное на внутренней организационной системе (то есть инновационная идея, а затем и продукт или технология, формируется и реализуется внутри фирмы ее специализированными структурными подразделениями с помощью планирования и мониторинга их взаимосотрудничества по инновационному проекту);

- предпринимательство в сфере инноваций, основанное на внешней организационной системе (то есть путем заключения контрактов, когда заказ на формирование и реализацию инновационного продукта или технологии расходится между сторонними предприятиями);

- предпринимательство в сфере инноваций, основанное на внешней венчурной организационной системе (то есть с использованием венчуров, когда предприятие для внедрения инновационного 
проекта учреждает дочерние венчурные фирмы, требующие привлечения дополнительных сторонних средств).

Наиболее используемой в условиях российской экономики является вторая модель предпринимательства в области инноваций, предполагающая размещение предприятием своего заказа на выработку инноваций, их дальнейшее освоение своими силами. Таким образом, в этом случае не предусмотрена выработка комплексных заказов «под ключ» и их дальнейшая реализация. Нечастое использование первой модели инновационного предпринимательства свидетельствует о недостаточном потенциале внутрифирменных научно-исследовательских и опытно-конструкторских работ. Следует отметить, что все три вышеупомянутые виды предпринимательства в сфере инноваций базируются на создании и освоении новейших разновидностей продукции (работ, услуг), изготовлении, разработке ценностей и благ. То есть основной принцип инновационного предпринимательства заключается в создании и производстве научнотехнической продукции, работ и услуг, информационных поводов, интеллектуальных ценностей [19].

Малые инновационные предприятия - это предприятия, разрабатывающие и внедряющие в производство наукоемкие технологии и изделия. Малые инновационные предприятия (МИП) выступают в качестве связующего звена между наукой и производством.

Существуют различные организационные формы малого инновационного предпринимательства. Малое инновационное предпринимательство связано с процессами формирования новых фирм в рамках старых компаний, созданием и функционированием рисковых фирм, разработкой и реализацией инкубаторных программ.

Универсального определения МИП не существует. Более того, в зарубежной практике используются различные варианты названий для такого рода организаций: инновационное малое предприятие (innovative SME), высокотехнологичная фирма (high technology firm), фирма новейшей технологии (new technology-based firm (NTBF), 
фирма, основанная на использовании знаний (knowledge-based firm), «эксплерент» - «фирма-новатор, которая сознательно идет на значительный риск, а получение прибылей от продажи новых товаров и технологий ставит в зависимость от одаренности интеллектуалов, работающих в фирме, и их неординарных плодотворных идей, предложений» и т.д.

Малые инновационные предприятия - это относительно новые хозяйствующие субъекты в сфере рыночной экономики, характеризующиеся независимостью и адаптивностью, призванные выполнять задачи по структурной перестройке производства, по расширению международного научно-технического сотрудничества и росту престижа страны в мире на основе разработки, освоения и реализации нововведений (прежде всего принципиально новых) и созданию обстановки восприимчивости к различным инновациям [13].

Среди организационных форм малого инновационного предпринимательства Г.В. Ушаков, А.Г. Ушаков в своем руководстве выделяют: новые фирмы в рамках старых компаний, венчурные фирмы - рискофирмы, инкубаторные программы и сети малых фирм Мы считаем, что одной из самостоятельных форм инновационных предприятий следует также считать инновационно-внедренческие предприятия.

Новые фирмы в рамках старых компаний представляют собой прогрессивный метод образования молодых компаний. Если в 1970-е и начале 1980-х годов новые компании на Западе создавались в основном инженерами и учеными, уходившими из фирм, то в настоящее время корпорации сами субсидируют организацию новых фирм для того, чтобы предотвратить уход ведущих работников, сманиваемых ищущими таланты вкладчиками рискового капитала. Они же позволяют привлечь на работу в свою корпорацию специалистов из других фирм. 
Способ действия «материнских» компаний заключается в принятии на себя всех финансовых вопросов молодых фирм, что позволяет материнской компании стать владельцем до 80\% новой фирмы (остальное - в руках сотрудников-основателей). В бухгалтерских книгах новая фирма может числиться как филиал, но фактически является отдельной компанией со своим советом директоров. Однако убытки от ее деятельности в начальном периоде развития могут вноситься в бухгалтерские книги материнской компании. В то же время субсидирующая компания не может получить 100\% прибылей фирмы-новичка, т.к. она не принадлежит ей полностью.

Некоторые компании, организовавшие внутри своей структуры новую фирму, делают ее своей полной собственностью. В подобном варианте сотрудники - основатели молодой фирмы обычно получают право приобретения в течение ряда лет акций по льготной цене. По истечении нескольких лет материнская компания - держатель контрольного пакета акций получает возможность выкупать акции, принадлежащие сотрудникам-основателям, которые получают определенные доходы от прироста капитала.

Следующей организационной формой малого инновационного предпринимательства является венчурная рискофирма, которая представляет собой организацию, создаваемую для реализации инновационного проекта, связанного со значительным риском.

Создание рискофирмы происходит следующим образом. Группа людей, располагающих оригинальной идеей, но не имеющих средств для ее осуществления, вступает в контакт с инвесторами (венчурными фондами). Этот контакт осуществляется через посредника: руководителя мелкого предприятия, который должен быть компетентен не только в научно-технической сфере деятельности, но и в области производства и реализации продукции (если идея связана с организацией производства). Как руководитель будущей рискофирмы он обеспечивает частичное финансирование проекта и ру- 
ководит рядом направлений деятельности в течение 3-7 лет, вплоть до того момента, когда рискофирма передает через продажу акций ведение дел более мощной финансово-производственной группировке, если достигнутый уровень развития требует расширения масштабов производства.

По оценке экономистов, в 15\% случаев рисковый капитал полностью теряется; 25\% рискофирм несут убытки в течение более длительного времени, чем предполагалось первоначально; 30\% рискофирм дают весьма скромную прибыль, но в 30\% случаев успех позволяет в течение всего нескольких лет многократно перекрыть прибылью все вложенные средства. Например, доходы фондов рискового капитала в США в среднем в 10-20 раз превышают сумму вложенного капитала.

Многие высокотехнологичные российские организации строят свою стратегию выживания на основе инкубаторных программ и представляют собой фирмы-инкубаторы. Данные фирмы являются еще одной организационной формой малого инновационного предпринимательства. Под фирмой-инкубатором понимают организацию, создаваемую местными органами власти или крупными компаниями с целью выращивания новых компаний. Фирмы-инкубаторы создаются для сдачи в аренду вновь организуемым компаниям за невысокую плату служебных помещений и предоставления им на льготных условиях ряда услуг, включающих возможность получения консультаций у экспертов по управленческим, техническим, экономическим, коммерческим и юридическим вопросам.

Фирмы-инкубаторы существуют трех типов:

- бесприбыльные фирмы, являющиеся самыми многочисленными. Они создаются, как правило, при поддержке местных органов власти. Взимаемая ими арендная плата с фирм-арендаторов обычно на 15-50\% ниже среднего уровня. Бесприбыльные фирмы- 
инкубаторы субсидируются местными организациями, заинтересованными в создании рабочих мест и экономическом развитии региона. Арендаторами могут быть промышленные фирмы, исследовательские, конструкторские и сервисные организации;

- ориентированные на получение прибыли - частные организации, общая численность которых постоянно увеличивается. В отличие от бесприбыльных фирм фирмы-инкубаторы второго типа, как правило, не предлагают сниженных тарифов на услуги, но они позволяют арендаторам, предоставляя им широкий спектр услуг, платить только за те, которыми арендатор фактически воспользовался;

- филиалы высших учебных заведений - оказывают наиболее эффективную помощь компаниям, собирающимся осуществлять разработку и выпуск технологически сложных изделий. Арендная плата может быть достаточно высокой, но она включает возможность пользоваться институтскими лабораториями, техническим обслуживанием, вычислительной техникой, библиотекой, иметь контакты с преподавателями.

Продолжительность пребывания в рамках фирмы-инкубатора ограничивается обычно тремя годами. Считается, что по истечении этого срока компания-арендатор должна достигнуть такой степени самостоятельности, которая позволит ей выйти из фирмыинкубатора. Укрепившие свои позиции в рамках фирмы-инкубатора, мелкие рисковые фирмы затем скупаются материнской компанией, которая организует на их базе новые исследовательско-конструкторские, опытно-экспериментальные и производственные подразделения. Создание фирм-инкубаторов является одной из форм поддержки инновационного процесса.

Первые бизнес-инкубаторы в России были рассчитаны в основном на поддержку прикладных технологий. Однако в дальнейшем, по мере накопления опыта работы, планируется все больше внима- 
ния уделять поддержке инновационных организаций. При этом, учитывая зарубежный опыт, предполагается финансировать инновационную деятельность за счет других направлений работы бизнесинкубатора и его малых оргструктур. Главным звеном инновационной политики компании являются научно-исследовательские подразделения [20].

Инновационно-внедренческая фирма - предприятие межотраслевого характера, созданное с целью реализации заключительной стадии научно-производственного цикла освоения новой продукции или внедрения существующей инновационной технологии. Данное предприятие выступает в качестве совершенно нового самостоятельного юридического образования, не относящегося к какой-либо компании. Предприятие имеет схожие черты с рискофирмой. Целью данной фирмы является освоение и практическое внедрение одного или нескольких инновационных проектов, в том числе при поддержке государства.

Отличительной особенностью данного предприятия является реализация только части инновационного цикла. Таким образом, инновационно-внедренческие предприятия не только самостоятельно внедряют инновации в стоматологическую пркатику, но и взаимодействуют с собственниками технологий, а также владельцами производств с открытием с третьими лицами дочерних предприятий, работающих по проектам, либо передачей части прав на реализацию инноваций с целью более эффективного внедрения этих инноваций в реальную практику.

Коммерциализация инновации - процесс превращения инновации в рыночный товар с целью извлечения прибыли. Процесс коммерциализации инноваций является ключевым этапом инновационной деятельности, в результате которого происходит возмещение затрат разработчика (или владельца) инновации и получение им прибыли от своей деятельности. 
Рассмотрим процедуру коммерциализации инноваций.

Создание новшества является конечным результатом любого инновационного процесса, однако важно еще до окончания разработок начать процесс коммерциализации [21, с.7]. Процесс коммерциализации можно представить в четыре этапа.

На первом этапе осуществляется поиск проекта в соответствии с критериями, предъявляемыми субъектами коммерциализации, происходит экспертиза проекта с точки зрения возможности его коммерциализации [22]. Анализируется потребность общества в инновационном продукте, востребованность у конечных потребителей в определенном сегменте, потенциал разработки, показатели экономической эффективности проекта (срок окупаемости, NPV, IRR), эффективность внутреннего использования. На основании проведенных исследований осуществляется отбор инноваций [23]. Поскольку только малая часть инновационных предприятий обладает необходимым объемом собственных средств для финансирования, второй этап характеризуется поиском инвестиций для внедрения инновационного продукта.

Третий этап является наиболее важным, поскольку здесь происходит распределение и юридическое закрепление прав на интеллектуальную собственность. В случае отсутствия предусмотренного законодательством оформления прав, новшество может быть свободно скопировано или зарегистрировано другими лицами. Важность распределения и закрепления прав объясняется еще и тем, что, кроме разработчика, в процессе коммерциализации принимают участие и другие субъекты: частные или государственные инвесторы, венчурные фонды, «бизнес-ангелы», кредитные учреждения. Учитывая интересы каждого из участников, закрепление прав на результат интеллектуальной деятельности является единственным возможным механизмом внедрения инновационных продуктов в реальный промышленный сектор. 
Четвертый этап коммерциализации включает в себя собственно внедрение инновации в производство, возможные дальнейшие коррективы и доработки. Таким образом, завершается процесс коммерциализации, на рынке появляется новый продукт, все участники начинают получать прибыль по обратной цепочке от предприятийпроизводителей до разработчиков. Особо важным является выбор способа коммерциализации, выделяют три основных:

- самостоятельный вывод продукта на рынок и прохождение всех вышеперечисленных этапов коммерциализации. В результате прибыль можно получать, сдавая инновационное оборудование в лизинг или оказывая инжиниринговые услуги, если инновации связаны с модернизацией производства;

- переуступка части прав на инновацию представляет собой продажу лицензии, что позволяет получать стабильную прибыль в виде роялти, также возможно продвижение инновационного продукта за счет средств лицензиата;

- полная передача прав на инновацию, предусматривающая продажу всех прав на инновационный продукт, что позволяет получать единовременно значительный доход, однако после продажи предприятию необходимо сменить сферу деятельности, поскольку прав на результат интеллектуальной деятельности оно больше не имеет [24].

Обсудим основные проблемы в коммерциализации инноваций.

На сегодняшний день процесс коммерциализации инноваций сталкивается со значительным рядом трудностей, которые препятствуют укреплению коммерциализации. К их числу можно отнести:

- необоснованную политику в области продаж, закупок и использования инновационных технологий; 
- выявление и выделение инноваций из многочисленных вариантов, составляющих суть проекта;

- нормативно-правовое обеспечение;

- оценку значимости инноваций для воспроизводства новых технологий и материалов, для их последующей коммерциализации;

- конфиденциальность инноваций;

- реализацию инновационных продуктов не только внутри страны, но и за ее пределами;

- обеспечение желаемых результатов предприятий и создателей инноваций с последующей коммерческой и промышленной реализацией;

- финансовое обеспечение;

- организационное обеспечение.

При выпуске готового товара на открытый рынок в течение первых двух лет необходимо пристальное внимание. Постоянный мониторинг позволит выявить и вовремя исправить все неточности. Основным показателем данного мониторинга служит выполнение объемов продаж, быстрое распространение среди потенциальных покупателей, что в результате помогает предпринять оперативные действия по снижению риска неокупаемости продукта.

Основные проблемы, приводящие к коммерческой неудаче, стоит разделить на внутренние и внешние. К внешним относятся причины, возникающие от неправильного восприятия потребителя окончательного продукта. В качестве основного фактора стоит выделить отсутствие отличительной характеристики от товара уже имеющегося на рынке, новый товар может не отвечать потребностям потребителей. Также есть опасность в выборе неправильной стратегии развития, что можно определить опросом потребителей. В качестве внутренних причин стоит выделить: 
- некачественное управление, характеризующееся недостаточной изученностью рынка, контроль бюджета, использование рискованных стратегий;

- отсутствие заинтересованности менеджеров. В основном данная характеристика основана на недостаточной заинтересованности менеджеров во введении нового товара на рынок. Многие менеджеры считают, что не стоит тратить ресурсы на новшества при стабильном доходе от уже существующего ассортимента. Также одним из слабых показателей в данной сфере считается достижение лишь краткосрочной прибыли;

- низкие темпы разработки новшества. На сегодняшний день в условиях ежедневного технологического развития жизненный цикл товара сокращается. При промедлении введения нового продукта на рынок стоимость разработки возрастает. Также возникает опасность во введении данного либо схожего инновационного товара на рынок другим предприятием;

- несистемный подход к разработке нового товара. Основой любого инновационного предприятия является оценка, реализация нового продукта. Небольшие фирмы поддерживают связь с клиентами для последующего изучения их потребностей при создании и нового продукта. Естественно, при увеличении компаний связи с потребителями ослабевают, что влечет за собой слабое изучение рынка;

- контроль и управление при разработке нового товара. Крупные предприятия, как правило, разобщены. Отделы по производству, сбыту, анализу, производству подчиняются разным менеджерам, в результате каждый отдел ставит перед собой цели, необходимые не только в рамках всей организации, но и в рамках каждого отдела. В итоге происходит слабый обмен информацией, разобщение интересов отделов. В связи с этим во многих крупных компаниях инновационные проекты закрываются, так и не успев реализоваться. 


\section{ГЛАВА 2. АНАЛИЗ МАКРОЭКОНОМИЧЕСКИХ УСЛОВИЙ ФУНКЦИОНИРОВАНИЯ МАЛОГО ИННОВАЦИОННОГО БИЗНЕСА}

\section{1. Экономико-правовая среда деятельности малых инновационных предприятий за рубежом}

Анализ западной литературы позволил получить представление о европейском подходе к созданию инноваций. Тройной кризис в Европе отрицательно сказался на бизнес-инновациях и НИОКР. Выход на рынок инновационных предприятий в Европе был затруднен, а рисковый капитал иссяк. Инвестиции в инновации пострадали из-за нестабильных рыночных условий и макроэкономической ситуации. Во времена неопределенности мало компаний увеличивают расходы на НИОКР и проводят инвестирование в инновации. Это особенно актуально для малых и средних предприятий (МСП), которые являются основой европейской экономики. Они представляют 99,8 \% всех предприятий в ЕС. За последние пять лет МСП создали около 85\% новых рабочих мест и обеспечили две трети общей занятости в частном секторе в ЕC.

В странах ЕС инновации контролируются и поддерживаются Европейской Комиссией (European Commission). Европейская комиссия рассматривает МСП и предпринимательство как ключ к обеспечению экономического роста, инноваций, создания рабочих мест и социальной интеграции в ЕС. В последнем информационном сообщении о политике (июнь 2014 года) изложены приоритеты Европейской комиссии в области инноваций. В этом контексте Генеральный директорат по внутреннему рынку, промышленности, предпринимательству и МСП:

- поддерживает инновационное развитие в приоритетных областях и на малых и средних предприятиях, в основном в рамках фонда Horizon 2020; 
- способствует широкой коммерциализации инноваций в ЕС, включая государственные закупки для инноваций, дизайн для инноваций, политику инноваций на стороне спроса, инновации в государственном секторе и социальные инновации;

- разрабатывает отраслевую политику для модернизации промышленной базы ЕС и ускорения освоения на рынке ключевых стимулирующих технологий, таких как инновации на рабочем месте;

- контролирует эффективность инноваций и их внедрение для выявления изменений, которые требуют изменений в политике. Ключевые методологии включают Европейские табло инноваций, Иннобарометры, Обсерватория бизнес-инноваций;

- улучшает регуляторные условия для инноваций с помощью мер для стартапов, предпринимательства, доступа к финансам, цифровой трансформации, единого рынка, интеллектуальной собственности и стандартов;

- поддерживает развитие и сотрудничество кластеров для стимулирования инноваций МСП.

В центре деятельности Комиссии находится Европейский закон о малом бизнесе (SBA), который обеспечивает всеобъемлющую политику МСП для ЕС и стран ЕC. SBA продвигает принцип «сначала подумай о малом» и продвигает предпринимательский дух среди граждан Европы.

Комиссия продвигает предпринимательство через План действий по предпринимательству, поддерживает обучение предпринимательству и предоставляет инструменты поддержки для начинающих предпринимателей. Приоритетом Комиссии является обеспечение того, чтобы предприятия могли полагаться на благоприятную деловую среду и максимально эффективно использовать трансграничную деятельность, как на едином рынке ЕС, так и за его пределами. Комиссия содействует коммерциализации и внедрению инноваций 
через программу Horizon 2020, Европейские структурные и инвестиционные фонды (ESIF), а также Европейский фонд стратегических инвестиций (EFSI).

«Horizon 2020» - это самая крупная программа исследований и инноваций в ЕС, на которую в течение 7 лет (с 2014 по 2020 годы) будет выделено около 80 млрд евро финансирования ЕС в дополнение к частным инвестициям, которые будут привлекать эти деньги. Он обещает больше прорывов, открытий и «первых мировых достижений», предлагая отличные идеи из лаборатории на рынок [26].

Новые европейские структурные и инвестиционные фонды (ESIF) выделят около 110 миллиардов евро на инновационную деятельность, информационно-коммуникационные технологии, конкурентоспособность малых и средних предприятий (МСП) и низкоуглеродную экономику. Регионы должны разработать стратегии умной специализации до получения финансирования ESIF для проектов в области инноваций. Этот процесс должен позволить регионам сосредоточить свои инвестиции на своих сравнительных преимуществах. Инвестиционный план для Европы направлен на оживление инвестиций в стратегические проекты в Европе, чтобы деньги доходили до реальной экономики. Инвестиционный план будет разработан Европейским фондом стратегических инвестиций (EFSI), чтобы помочь ускорить восстановление экономики и стимулировать инвестиции и рост в Европе.

Кроме централизованной поддержки стран ЕС, куда входят 28 государств: Австрия, Бельгия, Болгария, Великобритания, Венгрия, Германия, Греция, Дания, Ирландия, Испания, Италия, Кипр, Латвия, Литва, Люксембург, Мальта, Нидерланды, Польша, Португалия, Румыния, Словакия, Словения, Финляндия, Франция, Хорватия, Чехия, Швеция и Эстония, - в каждой из этих стран организованы национальные системы по поддержке развития инноваций. В данной работе изучение инновационной активности каждой из 
перечисленных стран в частности не представляется возможным. Страны-члены ЕС существенно отличаются как по государственному устройству, так и устройству своих экономико-правовых структур. В связи с этим процессы инновационного развития в каждой из этих стран протекают по-разному, характеризуясь своими темпами, масштабами и конкретными формами организации [27].

Для всех стран ЕС в последнее десятилетие прослеживается тенденция по созданию центров содействия трансферу и коммерциализации технологий в виде технологических (научных) парков и других инновационных образований. Создание технологических (научных) парков, в меньшей степени технополисов, в ЕС стало одной из важнейших составляющих государственной научно-технической политики, направленной на стимулирование инновационной активности, а также ускорение и облегчение структурной перестройки хозяйства на наукоемкую основу в большинстве стран-членов [28]. Общим для всех стран ЕС является также разработка государствами благоприятной среды для малого инновационного бизнеса, в особенности в виде организации налоговых льгот и выгодных кредитов для реализации НИОКР на предприятиях.

Рассмотрим развитие инноваций в США. В США также организована высоко децентрализованная и разнообразная инновационная система, включающая субъекты, в том числе ветви федеральных и региональных правительств, государственных учреждений, университетов, частный сектор, а также некоммерческие и посреднические организации. Система сочетает высокий уровень НИОКР (с фундаментальными исследованиями, финансируемыми, в частности, федеральными правительственными учреждениями) и сильную ориентацию на прикладное применение и рынок.

Федеральное правительство США оказывает поддержку инновациям через развитие инфраструктуры и рассматривает регулирующие меры, такие как режим интеллектуальной собственности, 
регулирование финансовых рынков и межштатную коммерцию. Федеральное правительство также спонсирует как фундаментальные, так и узкоспециализированные исследования, ориентированные на конкретные потребности исполнительных органов, причем на НИОКР в оборонной сфере приходится более половины всех федеральных расходов на НИОКР.

В инновационной системе США задействованы многочисленные и разнообразные субъекты из правительства, научной области, частного сектора и некоммерческих организаций.

Большинство инноваций в США осуществляется частной промышленностью. Частный сектор провел 71\% исследований и разработок в США в 2006 году, из которых 76\% составляли разработки, $20 \%$ - прикладные исследования, и только 4\% были фундаментальными исследованиями (Национальный совет по науке, 2008). Инновационная политика, кроме содействия НИОКР, также выделяет средства на разработку дизайна инновационных продуктов, технологические и организационные изменения, оборудование и программное обеспечение, обучение и маркетинг. Нет точных оценок всех инвестиций США в инновации, но они составляют значительно большую долю, чем показано данными по НИОКР. Среди фирм частного сектора инновации внедряются несколькими способами, включая через цепочки поставок, лицензирование интеллектуальной собственности и движение человеческого капитала между компаниями и другими типами учреждений. Есть большой и продвинутый сектор венчурного капитала для поддержки высокотехнологичных стартапов.

Нормативно-правовая база США в целом предрасположена к инновациям, в том числе поощряя новаторов рисковать и получать выгоды, связанные с инновациями. Инновации сосредоточены в трех областях: интеллектуальная собственность, налоговая политика и закупки. Интеллектуальная собственность управляется посредством офиса США по патентам и товарным знакам (US Patent and 
Trademark Office). В 2006 году в это подразделение поступило 440000 заявок на патенты и было одобрено более 196000 патентов, почти половина из которых выдана иностранным фирмам. В том же году было подано более 354000 заявок на товарные знаки. Большинство патентов принадлежит компаниям, причем менее 2\% патентов на полезные ископаемые принадлежит университетам. В США есть три типа патентов: на полезную модель, дизайн и оборудование. Патенты на бизнес-методы рассматриваются аналогично другим областям патентной экспертизы [29]. Налоговый кредит на НИОКР является основным фискальным инструментом (за исключением грантов или займов) для стимулирования НИОКР в частный сектор. Федеральный налоговый кредит (R\&E) изменялся много раз, но базовая структура предусматривает четыре вида налоговых льгот: обычный исследовательский кредит, альтернативный дополнительный исследовательский кредит, кредит на фундаментальные исследования и кредит на исследования в области энергетики. Первые три типа предложений предусматривают 20\%-е погашение расходов на НИОКР от базовой суммы, в то время как кредит на исследования в области энергетики заключается в погашении государством до 20\% платежей, осуществляемых предприятиями некоммерческим организациям за исследования в области энергетики.

Существует много национальных программ, которые стимулируют инновации в промышленности посредством прямого финансирования и технической помощи. Большинство из этих программ ориентированы на малый бизнес и многие из них находятся в университетах [30]. Одной из основных федеральных программ по финансированию НИОКР в малом бизнесе является Программа инновационных исследований малого бизнеса (SBIR), созданная еще в 1982 году. Одной из основных ценностей SBIR является развитие малого бизнеса в США. В соответствие с указами правительства США, в рамках данной программы одиннадцать федеральных агентств ежегодно выделяют бюджет на исследования и разработки 
в размере 100 млн долл. (77 млн евро), но не меньше, чем 2,5\% от своего бюджета для финансирования НИОКР в организациях, участвующих в SBIR [48]. Программа передовых технологий (Advanced Technology Program ATP) была создана в 1988 году для решения проблемы отсутствия совместной программы исследований и разработок между правительством и сферами экономической деятельности в стране, что ставило США позади Японии и других стран (Национальные Академии, 1999). Программа «АТР» предлагает соответствующие федеральные средства в коммерциализации технологий компаниям, занимающимся прикладными исследованиями в области технологий с высоким уровнем риска. По состоянию на 2005 г. фонд «АТР» выделил 70 наград на общую сумму 2,3 млрд долл. США (1,8 млрд евро), которые были распределены в частной промышленности. Большинство наград присуждается малым высокотехнологичным фирмам в таких областях, как электроника и фотоника; информационные технологии; передовые технологии, материалы и биотехнология. С момента своего создания АТР подвергалась значительной критике, в том числе от республиканских членов Конгресса и нынешней администрации, что это ненужное вмешательство правительства в аспекты инновационного процесса, которые лучше обрабатывается частным сектором. Закон США о Конкуренции (Публичный закон 110-69), подписанный 9 августа 2007 года, упразднил АТР.

Тем не менее, этот закон также направлен на стимулирование инноваций и использует многие принципы программы АТР. Индустриально-университетские центры кооперативных исследований (IUCRC) и инженерные исследовательские центры (ERC) - две инициативы Национального научного фонда (NSF) которые связывают образование, промышленность и исследовательские миссии. Оба проекта ориентированы на области исследований, важные с позиции коммерции, а также преследующие академический и образовательный интерес. 
По состоянию на 2007 год насчитывается 55 центров IUCRC, которые размещаются в отдельных университетах или сетях университетов. Более семисот фирм также являются членами этих центров (включая небольшое число правительственных учреждений и некоммерческие организации). NSF предоставляет начальные средства, чтобы помочь в создании этих центров, затем покрывает административные и другие расходы ежегодными выплатами в размере 50000 долл. США (38 400 евро) сроком на пять лет. Центры могут подать заявку на вторую пятилетнюю награду, после чего они должны быть самоокупаемыми. Также центры получают от 300000 долл. США (230 300 евро) ежегодно наличными за счет взносов членов частного сектора. Средний годовой бюджет IUCRC составляет 1-2 млн долл. (0,8-1,2 млн евро) [31]. Программа ЕRC была организована в 1985 году для поощрения создания университетских промышленных консорциумов вокруг областей исследования с высоким риском. ERC стремится стимулировать междисциплинарные командные подходы и отраслевые ориентации в инженерном образовании. NSF поддерживает каждый центр ERC в течение одиннадцати лет (при условии интенсивных проверок каждые три года) с выделением до 2 млн долл. в год. По состоянию на 2007 год насчитывается 20 центров ERC.

В 1950-х годах была создана Федеральная администрация малого бизнеса США (SBA), чтобы помочь малому бизнесу через предоставление финансовой и деловой помощи. Его программы предлагают кредиты для малого бизнеса, гарантии по кредитам, венчурный капитал, помощь при бедствиях, кредиты, предоставление необходимой информации, управленческую помощь и защиту. SBA делает доступным акционерный капитал для малых предприятий с заемными средствами по выгодным ставкам. Программа содействия торговле США (ТАА) была создана в 1974 году, чтобы помочь мелким и средним производителям преодолевать конкуренцию со стороны импорта. С годовым финансированием в размере около 10 млн долл. 
США (7,7 млн евро), эта программа предоставляет услуги производителям через сеть из 12 центров. Дальнейшее расширение центров произошло в начале 1990-х годов через Департамент Оборонных фондов США в рамках Федеральной программы реинвестирования технологий. Последующее финансирование из гражданского бюджета Министерства торговли США сформировало программу «МЕР», которая администрируется Национальным институтом стандартов и технологий в министерстве торговли США. Сегодня «МЕР» состоит из сети из 60 центров и более 300 местных офисов во всех 50 штатах. Они укомплектованы более 1000 профессиональными специалистами, как правило, с предшествующим производственным опытом.

Большинство центров оказывают практическую помощь с бизнес-услугами, системами качества, производственными системами, информационными технологиями, человеческими ресурсами, инжинирингом и разработкой продукции. Программа «МЕР» получает около 100 млн долл. США (76,8 млн евро) в год. Еще одним направлением деятельности на федеральном уровне является межотраслевое развитие человеческих и институциональных возможностей для инноваций. Эти действия происходят по всей стране, а также в отдельных отстающих штатах. В то время как человеческий капитал признан фундаментальным ресурсом в национальной инновационной системе, функционирование начального, среднего и высшего образования высоко децентрализовано среди пятидесяти штатов, тысяч местных школьных советов и самих учебных заведений. Обучение в государственных колледжах и университетах контролируется и в значительной степени финансируется на государственном уровне со значительной институциональной автономией, в то время как частные университеты имеют независимые уставы [32].

С 2008 года государственное финансирование НИОКР в сфере бизнеса США сократилось, главным образом, из-за сокращения 
бюджетов на оборону, в последнее время больше внимания уделяется прямой поддержке НИОКР и инноваций в бизнесе. В декабре 2015 года налоговый кредит на исследования и эксперименты был продлен и стал постоянным. В течение следующих нескольких лет большая доля инвестиций в НИОКР США, осуществляемых посредством конкурентных грантов, будет направляться малым предприятиям и консорциумам под руководством малого бизнеса. Технологические консалтинговые услуги/программы расширения были введены в 2013 году с акцентом на производство и новые фирмы, возникающие в результате достижений фундаментальных исследований. Правительство США продолжает предлагать расширение кредитных гарантий и механизмов распределения рисков, особенно в секторе чистой энергии.

В поддержку общенациональных усилий по объединению промышленности, университетов и федерального правительства для инвестирования в новейшие технологии, которые создадут рабочие места высокого качества, в бюджете на 2016 год было предусмотрено 2,9 млрд долл. США на федеральные исследования и разработки в области передовых технологий. В рамках этого конверта девять национальных сетей институтов инноваций в сфере производства получают более 600 млн долл. США в виде федеральных инвестиций и более 1,2 млрд долл. США в виде нефедеральных инвестиций. К январю 2017 года создано шесть дополнительных институтов для расширения передовых производственных технологий и процессов. Эти инвестиции позволят расширить исследования и разработки в области инновационных производственных процессов, передовых промышленных материалов и робототехники. И они дополнят текущие усилия по поощрению предпринимательства и улучшению переходов от открытия к рынку [33]. Тем не менее, в США организован комплексный подход к разработке инновационной политики и разработке программ, что долгое время приводило ее к мировому лидерству по инновационному развитию. 


\section{2. Анализ условий ведения малого инновационного бизнеса в России: проблемы и перспективы}

Малый инновационный бизнес в России в большей степени регулируется государственными органами, являясь фактором экономического развития страны на мировой арене. В России, как и в других странах, для поддержки инноваций введена национальная инновационная система. Структура национальной инновационной системы состоит из следующих элементов:

- государственной инновационной политики, направленной на стимулирование инновационной деятельности;

- производственного сектора (большие, средние и малые компании);

- сферы научно-исследовательских и опытно-конструкторских работ (НИОКР) и образования;

- сектора посредников, обеспечивающего трансфер инноваций (инновационные центры, брокеры и др.);

- инфраструктуры инновационной деятельности (технопарки, технополисы, бизнес-инкубаторы, центры трансфера технологий и т.д.);

- институциональных структур (финансовые институты, «бизнес-ангелы», страховые компании) [34].

В осуществлении стратегии инновационного развития Российской Федерации в период вплоть до 2020 года существенная значимость отводится малому инновационному предпринимательству. Выделены приоритетные направления развития науки и техники, куда входят энергосберегающие технологии и энергоэффективность, космические технологии, атомная промышленность, стратегические информационные технологии и медицина (в том числе стоматология). Исследования показывают, что небольшие современные компании разрабатывают более половины, а в сверхтехнологичных сек- 
торах экономики основную часть инноваций, но при этом имеют значительные недочеты, препятствующие их наиболее результативному функционированию.

Малые предприятия, вовлеченные в создание инноваций, имеют существенные преимущества, при этом организационно-правовая структура в РФ, специфика сфер экономической деятельности, экономическое развитие страны и прочие факторы приводят к трудностям функционирования малого инновационного бизнеса, выливающимся в недостатки таких предприятий (табл. 2).

Таблица 2

Преимущества и недостатки малых инновационных предприятий

\begin{tabular}{|c|c|}
\hline Преимущества & Недостатки \\
\hline $\begin{array}{l}\text { 1. Быстрое принятие решений и эластич- } \\
\text { ность управления }\end{array}$ & $\begin{array}{l}\text { 1. Трудности получения финансиро- } \\
\text { вания и кредитования }\end{array}$ \\
\hline $\begin{array}{l}\text { 2. Стремительная адаптация к рыночным } \\
\text { условиям }\end{array}$ & 2. Большая степень риска \\
\hline $\begin{array}{l}\text { 3. Незначительный уровень накладных за- } \\
\text { трат и потребностей в начальном капитале }\end{array}$ & $\begin{array}{l}\text { 3. Высокийуровень рыночной конку- } \\
\text { рентной борьбы со стороны крупных } \\
\text { компаний }\end{array}$ \\
\hline $\begin{array}{l}\text { 4. Вероятность непосредственного контак- } \\
\text { та с покупателем }\end{array}$ & $\begin{array}{l}\text { 4. Трудность коммерциализации но- } \\
\text { вых товаров и технологий }\end{array}$ \\
\hline $\begin{array}{l}\text { 5. Относительно более высокий оборот } \\
\text { денежных средств }\end{array}$ & $\begin{array}{l}\text { 5. Незначительная степень распреде- } \\
\text { ления рабочей силы }\end{array}$ \\
\hline $\begin{array}{l}\text { 6. Вероятность осуществления творческой } \\
\text { возможности и независимость при приме- } \\
\text { нении технологических ноу-хау в изготов- } \\
\text { лении }\end{array}$ & таток данных \\
\hline $\begin{array}{l}\text { 7. Значительная степень информированно- } \\
\text { сти о степени рыночного спроса }\end{array}$ & $\begin{array}{l}\text { 7. Низкий уровень мастерства ме- } \\
\text { неджеров в управлении предпри- } \\
\text { ятием }\end{array}$ \\
\hline $\begin{array}{l}\text { 8. Заменяемость сотрудников из-за про- } \\
\text { стой структуры отделов }\end{array}$ & $\begin{array}{l}8 . \quad \text { Нацеленность инноваций } \\
\text { на незначительные категории поку- } \\
\text { пателей }\end{array}$ \\
\hline 9. Источник новых рабочих мест & \\
\hline
\end{tabular}


Сегодня ключевыми трудностями функционирования и формирования малого инновационного бизнеса считаются:

- недостаток личных денежных средств у малых предприятий;

- необходимость национальной помощи;

- большая цена нововведений [35].

Государственная поддержка малого инновационного бизнеса имеет прямые (финансирование) и косвенные (налоговые и таможенные льготы) методы. Все они в определенной степени реализованы сегодня в России. Среди прямых методов стимулирования инноваций стоит выделить бюджетное и внебюджетное финансирование. К бюджетному финансированию относятся субсидии, гранты, а к внебюджетному банковские кредиты, собственные средства, специализированные и благотворительные фонды и т.д. Субсидии малому бизнесу - это один из востребованных и эффективных способов поддержки малого инновационного предпринимательства в России.

Субсидии представляют собой бюджетные денежные средства, которые предоставляются предприятиям на безвозмездной и безвозвратной основе с целью возмещения затрат предприятия, полученных в результате деятельности в научно-инновационной сфере. Субсидии предоставляются субъектам инновационной деятельности на условиях, что они будут рассматриваться как часть денежных средств на погашение кредита кредитным организациям или как возмещение части расходов на приобретение основных средств для производства инновационной продукции. К достоинствам субсидий относят возможность отбора проектов и поощрение социально значимых проектов или проектов с положительным внешним эффектом. Недостатками же можно назвать сложность отбора инновационных проектов и наличие рисков незаконного присвоения субсидий [36].

Размер субсидий регулируется на федеральном и региональных уровнях в соответствие с разработанными целевыми программами 
при поддержке министерств. Чаще всего размер субсидии составляет до 70\% от произведенных затрат предприятия, связанных с производством инновационной продукции (товаров, работ, услуг), после их документального подтверждения, но не более 500 тыс. рублей на один субъект инновационной деятельности в течение календарного года. На практике федеральные и региональные целевые программы имеют весьма скромный масштаб и систематически не выполняются [37]. Одним из основных способов стимулирования малого инновационного бизнеса в настоящий момент является выдача грантов предприятиям на конкурсной основе по приоритетным направлениям их деятельности в сфере инноваций.

Под грантами подразумеваются денежные средства, предоставляемые безвозмездно и безвозвратно как юридическим, так и физическим лицам на осуществление конкретных научных, научно-технических программ и проектов, инновационных проектов, проведение конкретных научных исследований на условиях, предусмотренных грантодателями. Государственные гранты, которые может получить предприятие в малом инновационном бизнесе можно разделить на два вида:

- инновационные и научно-технические - выделяются на инновационные и научно-технические разработки и их внедрение;

- гранты для некоммерческих неправительственных организаций - выделяются для решения значимых социальных и общественных задач.

Финансирование грантов осуществляется посредством государственных бюджетных средств, также прослеживается тенденция по привлечению внебюджетных средств из частного сектора экономика. Использование средств грантов должно подтверждаться отчетом, в котором должны присутствовать финансовый отчет, смета и прочее. Конкурсы на выдачу грантов осуществляют фонды. Грантодатели в лице государственных образований и в некоторых случаях сто- 
ронних частных организаций после осваивания предприятием средств гранта и реализации инновационного проекта могут потребовать неисключительное право на оформленные патенты, долю в бизнесе или же предоставить грант на безвозмездной основе. Цель грантообразующих фондов - поддержка фирм, занятых в инновационной сфере. Фонды проводят конкурсы и по их результатам предоставляют помощь юридическим лицам в виде субсидий и грантов на безвозмездной и возмездной основе. В России в настоящий момент работают более 100 грантообразующих фондов, поддерживающие как физических лиц в лице ученых и исследователей при поддержке вузов, так и юридических лиц в лице предприятий, peaлизующих проекты и исследования научной и инновационной направленности. Интерес для малого инновационного бизнеса представляют последние, самыми крупными из которых являются «Фонд содействия развитию малых форм предприятий в научно-технической сфере», «Фонд Сколково».

В Екатеринбурге и Свердловской области действуют «Екатеринбургский центр развития предпринимательства» и «Свердловский областной фонд поддержки предпринимательства», которые также поддерживают малый инновационный бизнес. В России совокупный объем грантов, выделяемых в 2017 году на исследования и разработки, составил более 100 млрд руб., из которых более 60\% выделяются предпринимательскому сектору. При этом больше половины этих средств расходуются впустую. Возможно, причиной нерационального распределения средств грантов является отсутствие возможности заложить личный интерес работников предприятия при осваивании средств грантов в виде стимулирующей заработной платы [38].

В последнее время все большее значение для стимулирования деятельности по созданию и внедрению инноваций приобретает инфраструктура инновационной деятельности. При участии и под- 
держке государства появился целый ряд новых форм организации инновационной деятельности, которые сегодня составляют основу инновационной инфраструктуры. К ним относятся технопарки, инновационно-технологические центры, инновационно-промышленные комплексы. Все они были созданы при прямом финансовом участии государства. К инновационной инфраструктуре можно также отнести наукограды, хотя они создавались еще в советское время для решения преимущественно оборонных задач.

Основным механизмом государственной поддержки технопарков на сегодня является софинансирование развития инженерной, транспортной и другой инфраструктуры строящихся объектов. По информации Мининформсвязи, инвестиции из федерального бюджета в строительство технопарков в 2007 г. составили 2 млрд руб. Столько же вложено из бюджетов регионов, в которых создаются пилотные проекты. На 2019 год насчитывается более 100 частных и государственных технопарков в 65 субъектах РФ [39].

Еще один вид инфраструктуры, который стал развиваться в России с начала 90-х гг., - это технологические инкубаторы. Инкубаторы представляют собой структуры, которые обычно являются частью технопарка и организуются для того, чтобы обеспечивать благоприятные условия малым инновационным фирмам на самых ранних, рисковых стадиях развития их проектов, когда еще сложно определить вероятность успеха.

В России технологические инкубаторы практически не получили развития. На сегодняшний день в высокотехнологической сфере созданы только три такие структуры: Международный технологический бизнес-инкубатор (IBTI) в Москве, а также основанные при его участии аналогичные подразделения в Нижнем Новгороде и Томске. Все они были созданы на зарубежные средства [40]. Наряду с прямыми мерами государственного регулирования инновацион- 
ной деятельности в России, большое значение имеют методы ее косвенного стимулирования.

Кредитование инновационных проектов в России не распространено среди банков, т.к. они, в основном, дают кредиты на высокорентабельные и быстро окупающиеся проекты и нехотя сотрудничают с технологическими компаниями, у которых высокие риски кредитования, длительные сроки окупаемости и отсутствие дохода или его низкий уровень на начальных этапах работы проекта. В связи с этим большинство банков отказываются финансировать такие компании без государственной поддержки.

В современной практике России участие государства в кредитовании сводится к субсидированию с целью предоставления государственных гарантий по обязательствам предприятия. Правительство РФ предоставляет бюджетные субсидии для уплаты процентов по кредитам субъектам инновационной деятельности денежно-кредитным организациям. Также государственная финансовая поддержка осуществляется в виде беспроцентного кредитования или кредитования по льготным процентным ставкам. Так, ставка по кредиту для юридических лиц находится в диапазоне 20-22\%, а для инновационных компаний составляет в среднем 7,5\% годовых.

Государство может выдавать госгарантии по кредитам либо облигационным займам, привлекаемых на осуществление инновационной деятельности, банкам с целью обеспечения исполнения обязательств по возврату кредита по результатам отбора на основании постановления Правительства Российской Федерации № 1016 от 14 декабря 2010 г. и № 1017 от 14 декабря 2010 г.

С целью стимулирования инновационной деятельности, модернизации, развития предприятий и поддержки малого и среднего бизнеса была создана государственная корпорация «Банк развития и внешнеэкономической деятельности (Внешэкономбанк)». На данный момент Внешэкономбанк участвует в реализации 66 инноваци- 
онных проектов, в следующих видах промышленности: обороннопромышленный комплекс, авиастроение, медицинская техника и фармацевтика, ракетно-космический комплекс, электронная промышленность, двигателестроение. Сейчас доля инновационных проектов в общем кредитном портфеле банка составляет $34,5 \%$. По состоянию на сентябрь 2015 года Внешэкономбанк принял решение о финансировании 47 инновационных проектов общей стоимостью порядка 1,3 трлн руб., размер участия ВЭБа - более 605,2 млрд руб. [57].

Еще одним слаборазвитым инструментом стимулирования в нашей стране является венчурное финансирование, под которым понимают инвестирование денежных средств в инновационные и высокорискованные проекты с целью получения максимальной прибыли. Инвесторы осуществляют свою поддержку компании либо через вложение денежных средств в акционерный капитал открытых или закрытых обществ в обмен на долю в нем, либо через предоставление инвестиционного кредита сроком от 3-7 лет. Чаще всего используют комбинированный метод, когда часть средств инвестируют в акционерный капитал, а другую предоставляют как кредит на беспроцентной основе либо с процентной ставкой на 2-4\% выше средней лондонской межбанковской ставки предложения. Чтобы снизить риск, инвесторы часто сами участвуют в управлении предприятием, входя в Совет директоров.

Венчурное финансирование, в отличие, от банковского кредита имеет ряд преимуществ, во-первых, его можно получить без гарантий и залогов, если успех проекта достаточно велик, во-вторых, участие инвесторов в развитии компании, в-третьих, дает возможность частным предприятиям развить свои смелые идеи и проекты и, наконец, дает возможность получить большую прибыль от результатов деятельности и создать новый рынок. 
Как правило, венчурное финансирование осуществляется через венчурные фонды, в России их общее количество приближается к 80, а самыми крупными из них являются «РосНано», «Фонд ВТБ» и Российская венчурная компания». Государственные заказы играют не маловажную роль для развития инновационных предприятий, так как формируют первоначальный спрос на их продукцию. Так, в рамках государственной политики в области инноваций была разработана федерально-контрактная система (ФКС) и государственно-частное партнерство. В России государственный заказ является самым эффективным инструментом стимулирования инноваций, т.к. $70 \%$ всех товаров приобретается государством и государственными компаниями, а 5\% всей продукции, закупаемой субъектами РФ, входят в перечень инновационных товаров.

В 2018 году Россия впервые включена в отчет о рейтинге EIS наряду с другими странами БРИКС, а также Австралией, Канадой, США, Южной Кореей и Японией в рамках сравнительного анализа уровня инновационного развития ЕС с глобальными конкурентами. EIS-2018 включает 27 индикаторов (рис. 3), характеризующих рамочные условия развития НИС, инвестиции в инновации и связанные с ними виды деятельности, инновационную активность организаций, её прямые и косвенные эффекты [41].

Позиции России по отношению к инновационному развитию стран Европейского союза по методологии Европейского инновационного индекса 2018 (European Innovation Scoreboard, EIS) определил Институт статистических исследований и экономики знаний (ИСИЭЗ) НИУ ВШЭ. Согласно оценкам по сокращенному набору показателей (16 из 27), Россия отнесена к категории стран с относительно низким по сравнению с ЕС уровнем инновационного развития (рис. 4). Расчеты по полной методологии EIS выводят Россию на 25-е место среди стран, оцениваемых в EIS-2018. Ее показатели вы- 
ше значений Болгарии, Венгрии, Греции, Латвии, Македонии, Польши, Румынии, Сербии, Словакии, Турции, Украины и Хорватии [63]. Российская Федерация предпринимает активные меры по стимулированию инновационной деятельности, но в среднем по сферам экономической деятельности продукции пока лишь 10\% предприятий заняты в инновационном секторе. Эти показатели значительно ниже, чем в ряде других стран, в связи с этим встает необходимость изучения опыта зарубежных стран и развитие собственных инструментов стимулирования инновационной деятельности. Но стоит иметь в виду, что в мире не существует идеальной модели стимулирования и прежде всего стране нужно обращать внимания на свои экономические возможности по осуществлению тех или иных мероприятий.

При создании предприятия инновационно-внедренческой направленности, в том числе и в стоматологии, следует использовать все вышеперечисленные механизмы поддержки инноваций. К сожалению, в отличие от промышленно развитых стран ЕС и США, в России недостаточно развита косвенная поддержка инноваций в виде налоговых стимулов и льгот, сохраняется приоритет прямой государственной поддержки. Между тем, кредитование для развития НИОКР под низкую процентную ставку имеет силу, что следует активно использовать. 


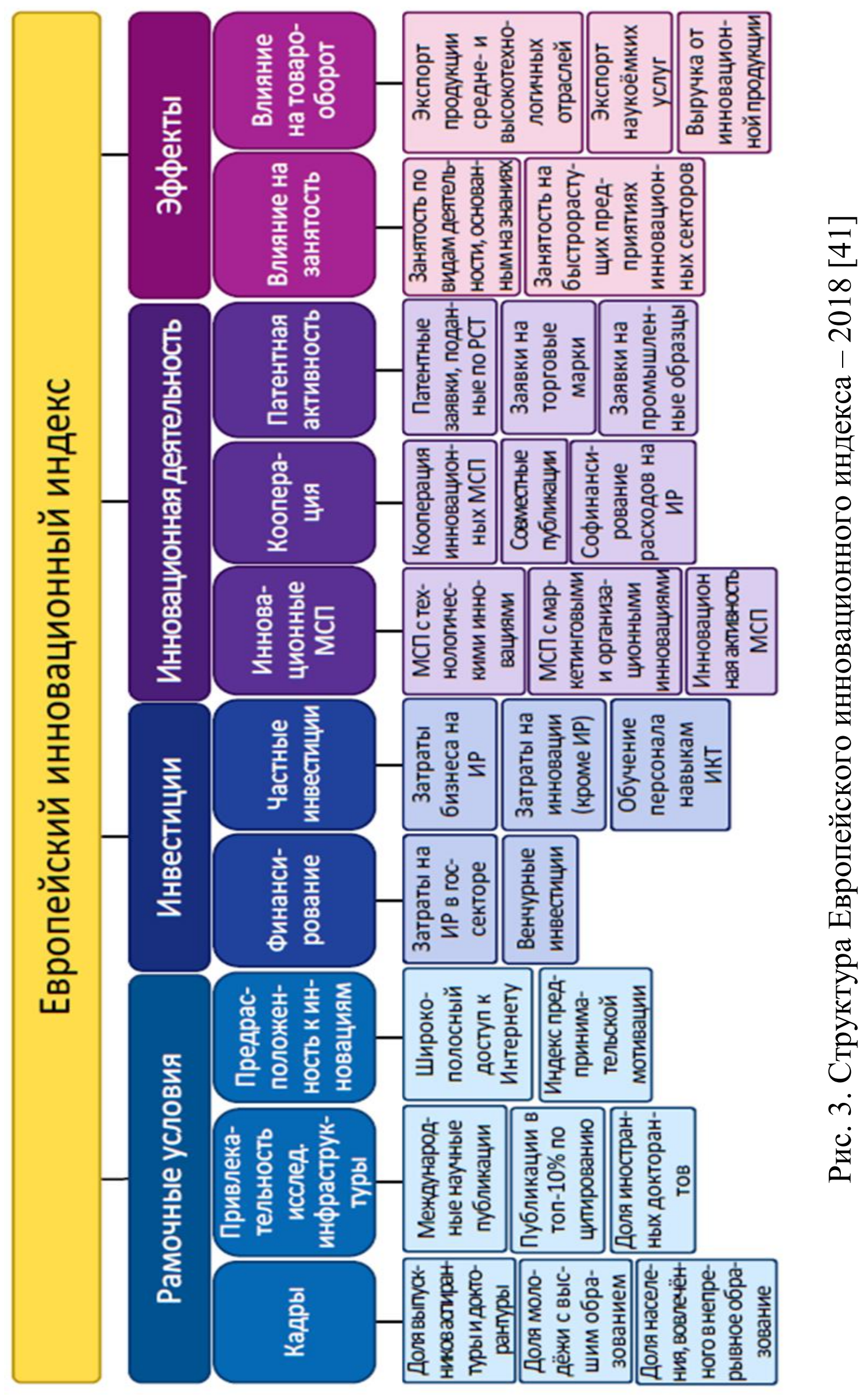



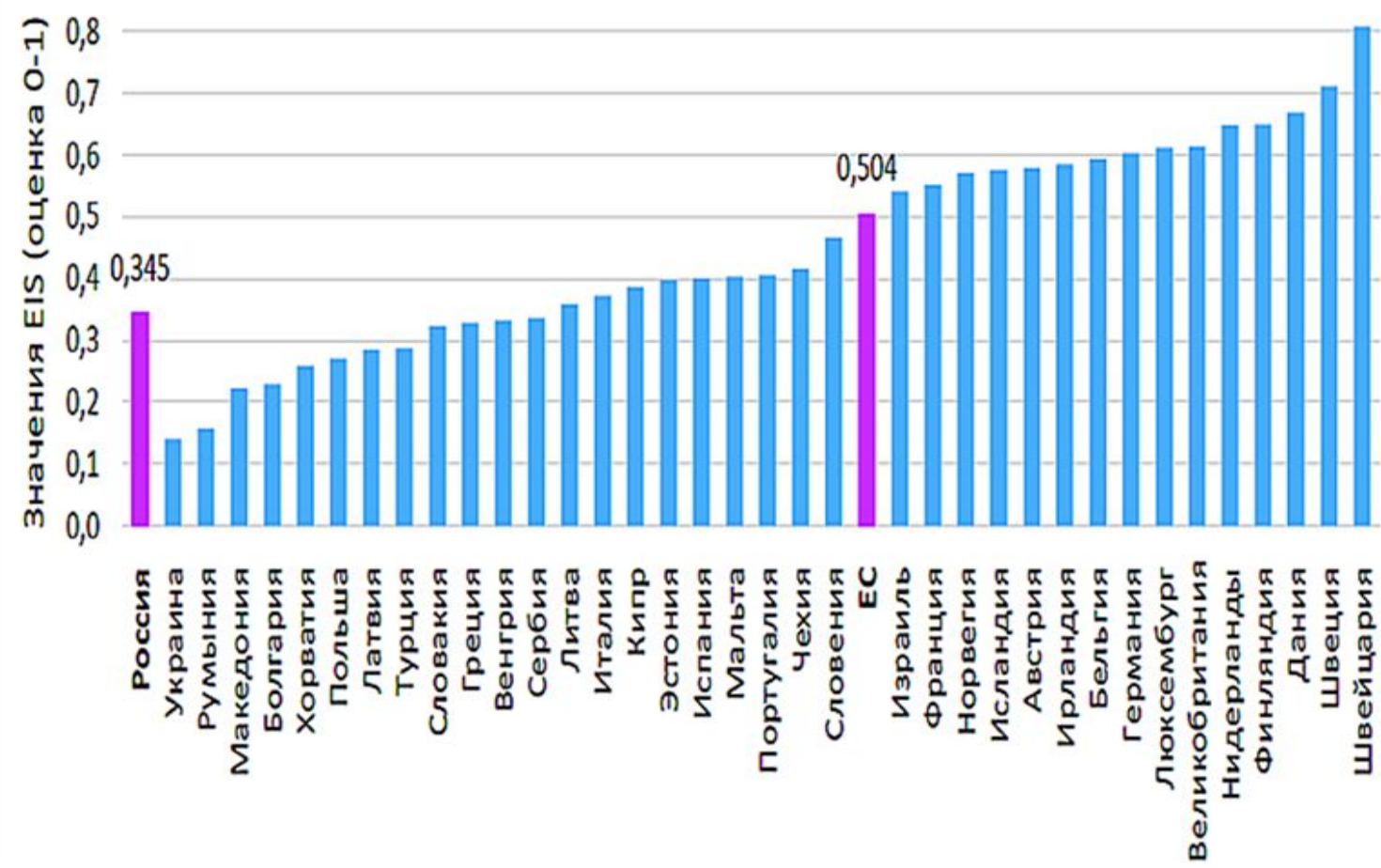

Рис. 4. Европейский инновационный индекс - 2018 России и стран Европы [41]

Среди грантообразующих фондов целесообразно обратиться за помощью в «Фонд содействия развитию малых форм предприятий в научно-технической сфере», «Фонд Сколково», а также использовать возможности региональных государственных фондов, в частности «Екатеринбургский центр развития предпринимательства» и «Свердловский областной фонд поддержки предпринимательства». Как показывает практика, венчурное финансирование имеет определенные риски на начальных этапах реализации инновационных проектов в виде интересов компаний, которые выделяют средства на проекты. Государственные заказы также один из инструментов, который может помочь. Требуются корректировки законодательно-правовых баз для дальнейшего развития методов косвенного стимулирования развития инноваций в Российской Федерации аналогично западным странам. Тем не менее, в России достаточно благоприятная среда для малого инновационного бизнеса и при правильной организации работы на предприятиях, вовлеченных в малый инновационный бизнес, проекты инновационно-внедренческой направленности имеют все шансы на успех. 


\section{ГЛАВА З. ОРГАНИЗАЦИОННО-МЕТОДИЧЕСКОЕ ОБЕСПЕЧЕНИЕ СОЗДАНИЯ И ФУНКЦИОНИРОВАНИЯ МАЛОГО ИННОВАЦИОННО-ВНЕДРЕНЧЕСКОГО ПРЕДПРИЯТИЯ (НА ПРИМЕРЕ ПРЕДПРИЯТИЯ В СФЕРЕ СТОМАТОЛОГИИ)}

\section{1. Особенности ведения бизнеса и проблемы внедрения инноваций в сфере стоматологии}

В данном разделе организационно-методическое обеспечение создания малогно инновационного предприятия будет описываться на примере малого инновационно-внедренческого предприятия, создаваемого в сфере стоматологии. В этой сфере выделяются рынки собственно стоматологических услуг, а также рынки материалов, оборудования и инструментов. Речь пойдет о рынке стоматологических материалов.

Анализ развития бизнеса в сфере материального обеспечения стоматологии затруднен из-за весьма ограниченного доступа к экономической и финансовой информации о предприятиях, работающих в этой сфере. Как правило, это небольшие компании, имеющие юридическую форму закрытого акционерного общества или общества с ограниченной ответственностью. Такие фирмы не обязаны публично размещать данные о своем развитии. Помимо этого, в целях оптимизации налогообложения и защиты бизнеса от недружественных захватов и поглощений компании имеют сложные юридические структуры, в некоторых случаях включающие несколько аффилированных между собой юридических лиц.

В результате, для оценки реальных объемов производства и продаж необходимо располагать консолидированными данными о всей группе компаний, составляющих конкретный бизнес. Последнее обстоятельство еще более затрудняет количественные оценки в данной области предпринимательской деятельности. Исключение 
составляют предприятия, имеющие юридическую форму открытых акционерных обществ, которые обязаны публиковать информацию о результатах своей деятельности, структуре собственности, существенных сделках и т.д. Однако таких предприятий в данной сфере предпринимательской деятельности немного. По нашим приблизительным подсчетам, доля отечественных стоматологических сегодня составляет не более $10 \%$ от общего объема применяемых в стоматологии материалов.

На рубеже 80-90-х годов XX века в России имело место неудовлетворительное положение в сфере материально-технического обеспечения стоматологии. Выпускавшиеся советской промышленностью стоматологические инструменты и материалы были низкого качества. Кроме того, имел место дефицит даже этих низкокачественных предметов и средств труда врачей-стоматологов. В конце 80-х годов ХХ века в России потребность по многим медицинским инструментам, включая стоматологические, удовлетворялась на 15-30\%. Поэтому в начале постсоветского периода в России остро стояла задача обеспечения сферы стоматологии качественными стоматологическими инструментами, оборудованием и материалами. Эта задача была решена двумя путями:

- массовым импортом современного оборудования, инструмента и материалов;

- созданием частным бизнесом производства стоматологических инструментов и материалов внутри страны.

Отсутствие на рынке качественных отечественных стоматологических материалов и инструментов и дороговизна импорта стимулировали в 90-е годы создание в сфере стоматологии целого ряда частных предприятий, часть из которых успешно развилась, обеспечила частичное импортозамещение по стоматологическим материалам и инструментам. Примером таких компаний являются ООО «ВладМиВа» (г. Белгород), производственный комплекс «Аверон» (г. Ека- 
теринбург), группа компаний «Русимплант» (г. Москва), ООО «РусАтлант» (г. Москва) и др.

Среди стоматологических услуг выделяют четыре базовых направления: терапевтические, хирургические, ортодонтические и ортопедические услуги.

Ортопедические услуги (зубное протезирование) по нашим подсчетам занимают около $30 \%$ от общего объема услуг. При этом доля ортопедических услуг растет с появлением сегодня эстетических конструкций в виде керамических виниров, накладок, которые заказывают, в том числе, молодые пациенты, желающие «преобразить» свою улыбку.

В настоящее время основным материалом для зубного протезирования в России является металлокерамика (70\% рынка), которая состоит из металлического каркаса и облицовочного слоя керамики. Остальные 30\% - это более дорогие безметалловые материалы, состоящие полностью из керамики, к которым относится и диоксид циркония (20\%). Между тем, процент безметалловых материалов растет и к 2020 году будет составлять до 50\% работ. Безметалловые контструкции являются элементом цифровой стоматологии. Их изготовление представляет собой технологию Cad-Cam, включающую в себя цифровое моделирование конструкций (Computer-AidedDesign) и их последующее фрезерование (Computer-Aided-Manufacturing) из специальных заготовок, чаще всего в виде стандартных керамических дисков 98 мм в диаметре $[42,43]$.

Среди отечественных производителей керамики сегодня функционирует новосибирский завод ЗАО «Нэвз-Керамикс», который производит в том числе и керамические Cad-Cam заготовки для стоматологии в небольшом количестве. В конце 2017 года на стоматологический рынок официально вышла девелоперская компания Sun Development со своим проектом «Циркон Керамика». Компания хочет производить из японского сырья циркониевые заготовки для 
Cad-Cam оборудования. Сегодня эти предприятия стараются расширять свою долю на российском рынке, однако, процент импортной продукции во много раз превышает отечественные аналоги. Так, среди зарубежных фирм, выпускающих большую долю по керамическим материалам, занимают фирмы 3M ESPE (США), Ivoclar Vivadent (Германия), Sirona Dental (Германия), изготавливающие керамику премиум класса, а также множество китайских фирм.

В последние два десятилетия российская медицинская промышленность развивалась в условиях жесткой конкуренции, которая осуществлялась с двух сторон. С одной стороны, на рынок России ввозится большое количество высококачественной дорогой продукции, произведенной в странах ЕС, США, Японии и продукции в среднем ценовом сегменте, произведенной в Южной Корее. Эти товары в основном приобретаются частным сектором стоматологического бизнеса. С другой стороны, в последние годы на российский рынок начался массовый ввоз дешевой продукции из Китая и Бразилии, которая начала оказывать давление на российских производителей на их традиционном рынке - поставках для государственных лечебных заведений. Таким образом, развитие технолгий в стоматологии тормозится иностранными конкурентами.

Второй проблемой, связанной с низкой долей отечественных стоматологических материалов, является полная незаинтересованность промежуточных покупателей продукции - стоматологических клиник и лабораторий, так как многие владельцы данных структур также активно занимаются торговлей стоматологическими материалами и имеют свои личные интересы по продвижению конкретной продукции. Доктора, которые работают в клиниках, регулярно ездят на учебу, в том числе и за рубеж, при этом везде фигурируют лишь иностранные бренды.

Укрепляют позиции иностранных продуктов и рекомендации стоматологических ассоциаций, крупнейшими из которых являются 
«СтАР» и «Ассоциация Цифровой Стоматологии». Сами ассоциации внушают конечному потребителю - пациенту, что иностранные материалы и оборудование являются залогом высокого качества. Более того, владельцы крупнейших клиник и лабораторий, чаще всего состоят в этих ассоциациях, таким образом, и персонал в этих клиниках и лабораториях не имеет возможности работать с отечественными производителями. В результате стоматологический рынок представляет из себя нечто вроде сетевой структуры, где всем активно навязываются западные ценности.

Законодательством установлено обязательное сертифицирование отечественной медицинской продукции. К медицинским изделиям относится все, что применяется в медицине: изделия, оборудование, медицинские аппараты, их программное обеспечение, лекарства и прочее. Стоматологическое оборудование и материалы также относятся к медицинским изделиям. Действие любого медицинского изделия направлено на восстановление здоровья человека. Медицинские изделия - это особый вид продукции, соответствие установленным стандартам которой проверяются очень строго и с большей тщательностью. Сертификация медицинских изделий начинается с предварительной проверки технической документации на сертифицируемое медицинское оборудование. Техническую документацию производитель обязан предоставить самостоятельно. Клинические и лабораторные испытания - это следующий этап, по которому проводится сертификация медицинских изделий. Испытания показывают насколько та или иная продукция медицинского назначения соответствует нормам и стандартам, которые были установлены в России относительно продукции здравоохранения.

Стандартизация и сертификация медицинских изделий служат пропуском для выхода продукции на рынок. На основе лабораторных испытаний и протоколов испытаний орган по сертификации выдает разрешительные документы: сертификат соответствия, декла- 
рацию о соответствии, регистрационное удостоверение Минздрава России и др. На практике сертифицирование отечественной стоматологической продукции оказывается достаточно сложным процессом, не исключающим коррупционных составляющих. Гораздо проще получить сертификат на ввоз импортной стоматологической продукции.

Инновационный бизнес в стоматологии сегодня требует активной организационной государственной поддержки. Необходимо наметить важнейшие цели инновационной политики государства. Это может быть и расширение российского участия на международном рынке инноваций, и защита государственного права на интеллектуальную собственность, созданную на государственные же деньги, и формирование рабочих мест в наукоградах; наращивание налоговых поступлений от коммерциализации научных результатов. Приоритеты определят стратегию и тактику участников рынка инноваций. На основе действующих инновационных субъектов малого и среднего бизнеса, имеющих международный опыт работы на рынке технологий, можно формировать крупные маркетингово-инновационные центры в целях продвижения инноваций в России, которые должны выработать механизм расширения присутствия России в том числе и на международном инновационном стоматологическом рынке.

Статистические данные свидетельствуют о вариации доли инновационного бизнеса в структуре российского малого предпринимательства от 1,4\% до 3,5\%. Инновационных предприятий в Российской Федерации много, но лишь порядка $15 \%$ из них могут называться инновационными. Подавляющее большинство фирм утратило свою настоящую инновационную составляющую.

Важная проблема - кадровое обеспечение предпринимательства в сфере инноваций. Российские реалии свидетельствуют о недостаточности опыта и знаний у менеджеров, продвигающих инноваци- 
онные продукты на рынке. До сих пор российская наука не избавлена и от «утечки мозгов». Особо остро стоит проблема инфляции. Известно, что за последние времена обозначились качественные улучшения в данном отношении, но на инновационном предпринимательстве сильно отображается всякое изменение. Любой из инновационных циклов протекает приблизительно от трех до пяти лет, а в течение этого времени первоначальный бизнес-план вдруг оказывается морально устаревшим. Постоянные изменения не позволяют предсказать, например, расходы производства.

\section{2. Элементы организационно-экономического механизма создания малого инновационно-внедренческого предприятия}

Традиционно высокотехнологичными считаются сферы экономической деятельности с большими затратами на НИОКР: более 4\% дохода. Среднетехнологичные предприятия тратят от 1 до 4\%. Доля НИОКР менее 1\% характерна для низкотехнологичных сфер деятельности, таких как, например, текстильные или пищевые производства.

Фирмы «традиционных» сфер экономической деятельности долго развивались, и в результате их работы появились установленные стандарты, традиционные методы и привычные знания, связанные как с продуктами, так и с бизнес-процессами. Большинство этих сфер находятся на поздних фазах своих производственных жизненных циклов. Это, пожалуй, одна из самых важных причин их сложной конкурентной позиции: основные технологии и процедуры, используемые в производстве, хорошо известны и часто могут быть легко скопированы конкурентами (в том числе иностранными), имеющими более низкие издержки.

Именно поэтому в сфере отечественной стоматологии, которая по своей активности, по нашему мнению, входит в состав традиционных сфер экономической деятельности, прослеживается тенден- 
ция к развитию зарубежных продуктов с сокращением издержек в себестоимости.

Нами выделены следующие причины низкого уровня развития инноваций в сфере отечественной стоматологии:

- дефицит финансовых ресурсов на развитие новых продуктов;

- инертность в сфере осуществления нововведений;

- неразвитость системы маркетинговых исследований;

- неразвитость инновационно-ориентированных подразделений на предприятиях;

- отсутствие рыночных возможностей внедрения;

- отсутствие на предприятии персонала необходимой квалификации;

- недостаточная эффективность стратегической маркетинговой функции;

- низкая диверсификация;

- неразвитость системы поиска и обработки внешнего знания;

- сфокусированность предприятий на оказании стоматологических услуг [44].

Наиболее важным фактором, способствующим активизации инновационной деятельности предприятий в сфере стоматологии, является появление товаров высокой степени рыночной новизны, которые являются старым товарами для прежних рынков, но новыми для данного, нового рынка. Появление таких товаров не только ужесточает конкурентную обстановку, но и основывает новое направление для улучающих инноваций.

Перспективным инструментом в развитии инноваций в стоматологии является межотраслевой и патентный поиск инновационных идей. 
Малые инновационные фирмы (эксплеренты) - технологические лидеры в зарождающихся сферах экономической деятельности, открывающие новые сегменты рынка, развивающие новые производства, повышающие наукоемкость и конкурентоспособность производства и тем самым способствующие формированию новых технологических укладов.

В стоматологии в связи со всем вышесказанным, нужны не просто инновационные предприятия, а инновационно-внедренческие, предметом деятельности которых будет именно внедрение инноваций в деятельность остальных участников стоматологического рынка. Так как в сфере стоматологии такие предприятия являются новыми по своей структуре, необходимо проработать организационно-методические вопросы их создания и функционирования.

Малое инновационно-внедренческое предприятие в стоматологии - самостоятельная форма предприятий, занимающаяся инновациями. Специфика предприятия - содействие развитию сферы стоматологии посредством распространения инноваций не только с их самостоятельным развитием, но и с возможностью частичной передачи прав на эти инновации. Остальные формы инновационных предприятий находят инновационные идеи и реализуют их самостоятельно. Данная форма развития инноваций, на наш взгляд имеет недостатки, связанные с высоким риском гибели инновации ввиду ограниченных возможностей таких предприятий. В связи с этим мы предлагаем более мобильную форму организации развития инноваций. Концептуальная схема работы предприятия представлена на рис. 5.

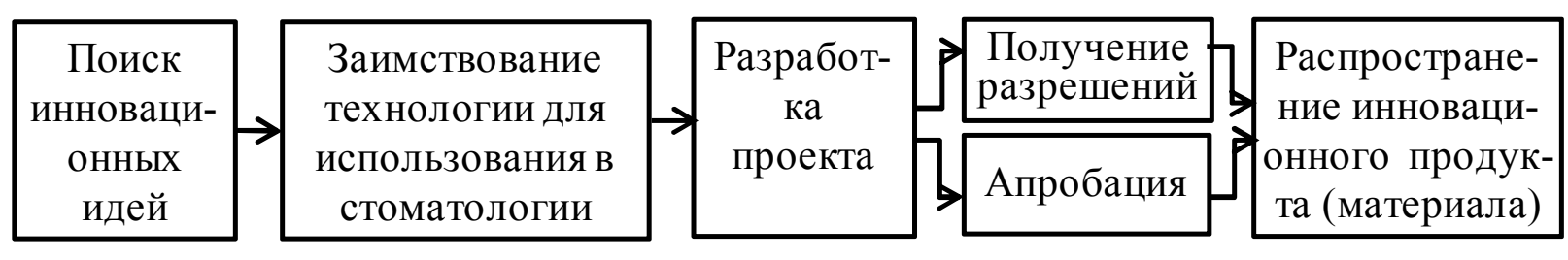

Рис. 5. Концептуальная схема работы инновационно-внедренческого предприятия 
Предлагаемое малое инновационное предприятие в сфере стоматологии будет иметь организационно-правовую форму ООО, в соответствие с законодательством РФ, уставной капитал которого разделен на доли. Причина выбора формы ООО на малом инновационном предприятии - наличие нескольких учредителей, имеющих собственные средства для возможности функционирования предприятия на начальных этапах его деятельности. Благодаря данной организационно-правовой форме в состав предприятия возможно включать другие юридические лица, необходимые для реализации инновационных проектов.

Процесс создания предприятия включают в себя три последовательных этапа. Первым этапом является регистрация ООО, включающая в себя такие мероприятия, как наименование ООО, указание видов экономической деятельности по ОКВЭД 2, выбор системы налогообложения, разработка устава компании, изготовление круглой печати ООО, получение кодов статистики, открытие банковского счета, получение лицензий, приобретение онлайн-кассы и др. Среди лицензий необходимо получить лицензию на производство медицинской техники и оборудования, а также в идеале на стоматологическую практику (для более эффективной апробации реализуемых на предприятии инноваций).

Второй этап создания предприятия представляет его подготовку к работе. В него входят подготовка, ремонт имеющегося (поиск) помещения для работы; покупка необходимого оборудования; набор и обучение персонала; организация бухгалтерского учета; поиск и организация производственных мощностей. С основным помещением для малого инновационного предприятия необходимо определиться также на этапе регистрации ООО. Параллельно со вторым этапом проходит третий этап, связанный с определением организационной структуры предприятия. Предложена функциональноматичная организационная структура для инновационно-внедренческого предприятия, которая будет подробно раскрыта далее. 
Четвертым этапом создания предприятия является непосредственно его начало работы. В процессе работы малого инновационного предприятия в сфере стоматологии предполагается его расширение с арендой или покупкой дополнительных площадей, дополнительной покупкой необходимого оборудования и получения необходимых дополнительных лицензий, связанных с реализацией выбранных инновационных идей, заключение договоров на производство со сторонними предприятиями.

На этапе подготовки видов деятельности по ОКВЭД 2 наиболее важным является заявление максимально большего количества видов деятельности, так как предполагается разнонаправленная работа предприятия в сфере стоматологических инноваций.

По мере функционирования и развития предприятия для более эффективного продвижения инноваций предлагается организация совместных дочерних предприятий с третьими лицами в виде собственников ноу-хау, производителей, а также крупных потребителей (зуботехнических лабораторий, торговых стоматологических домов, крупных сетей стоматологических клиник). Таким образом, инновационно-внедренческое предприятие трансформируется в сетевую компанию, представляющую собой холдинг с дочерними предприятиями, каждое из которых сфокусировано на конкретном инновационном проекте или направлении. Таким образом, происходит пятый этап создания и развития предприятия, связанный с развитием организационной структуры инновационно-внедренческого предприятия. Для дочерних предприятий, работающих по инновационным проектам, предлагается линейная организационная структура. Организационная структура инновационно-внедренческого предприятия, в подчинении которого находятся созданные на базе его дочерние предприятия, работающие по инновационным проектам, представлена на рис. 6. Соучастие партнеров в реализации проектов с организацией дочерних предприятий обеспечивает компании дополнительные возможности за счет имеющихся у партнеров активов. 


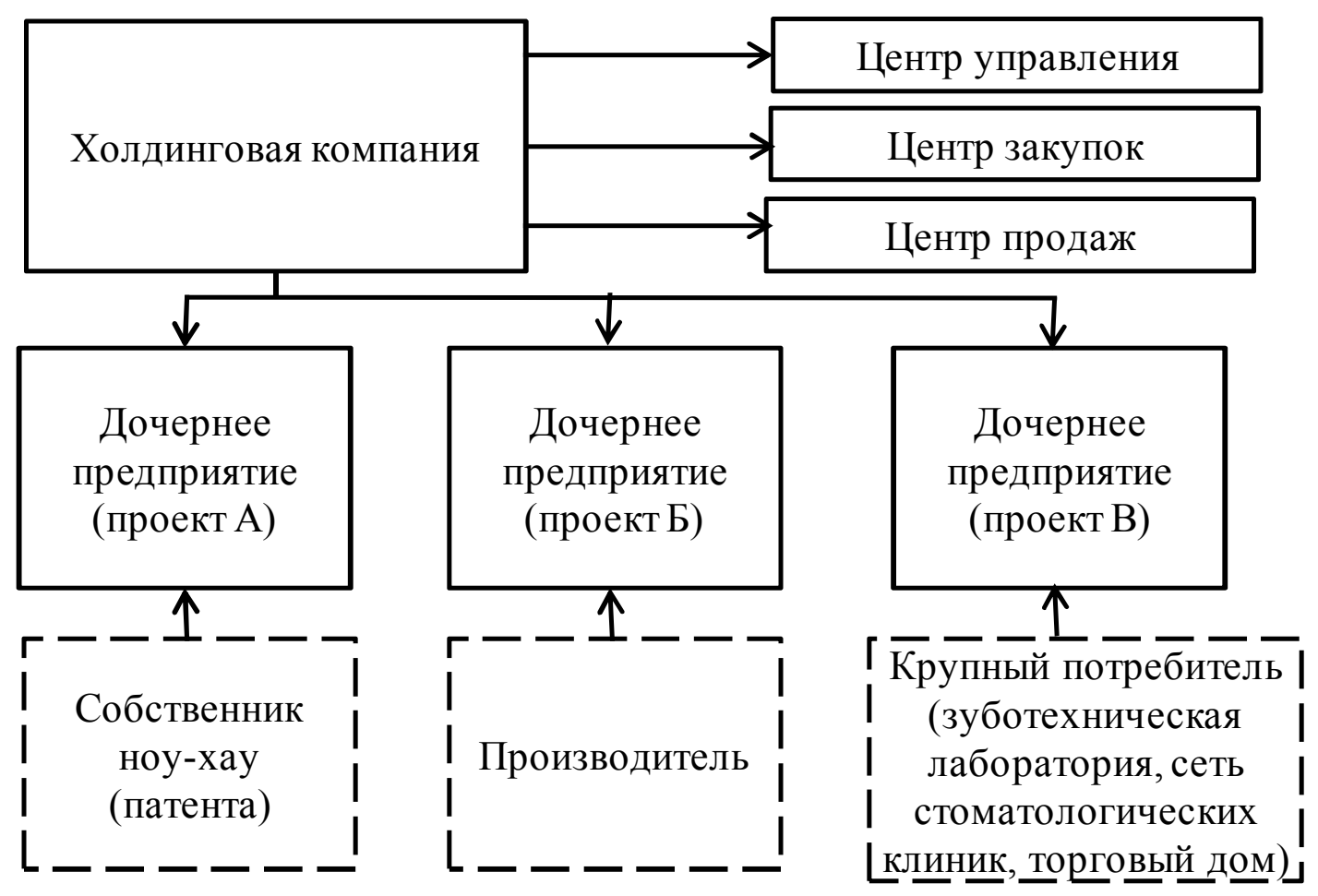

Рис. 6. Организационная структура инновационно-внедренческого предприятия

Этапы создания и развития инновационно-внедренческого предприятия представлены в виде схемы на рис. 7.

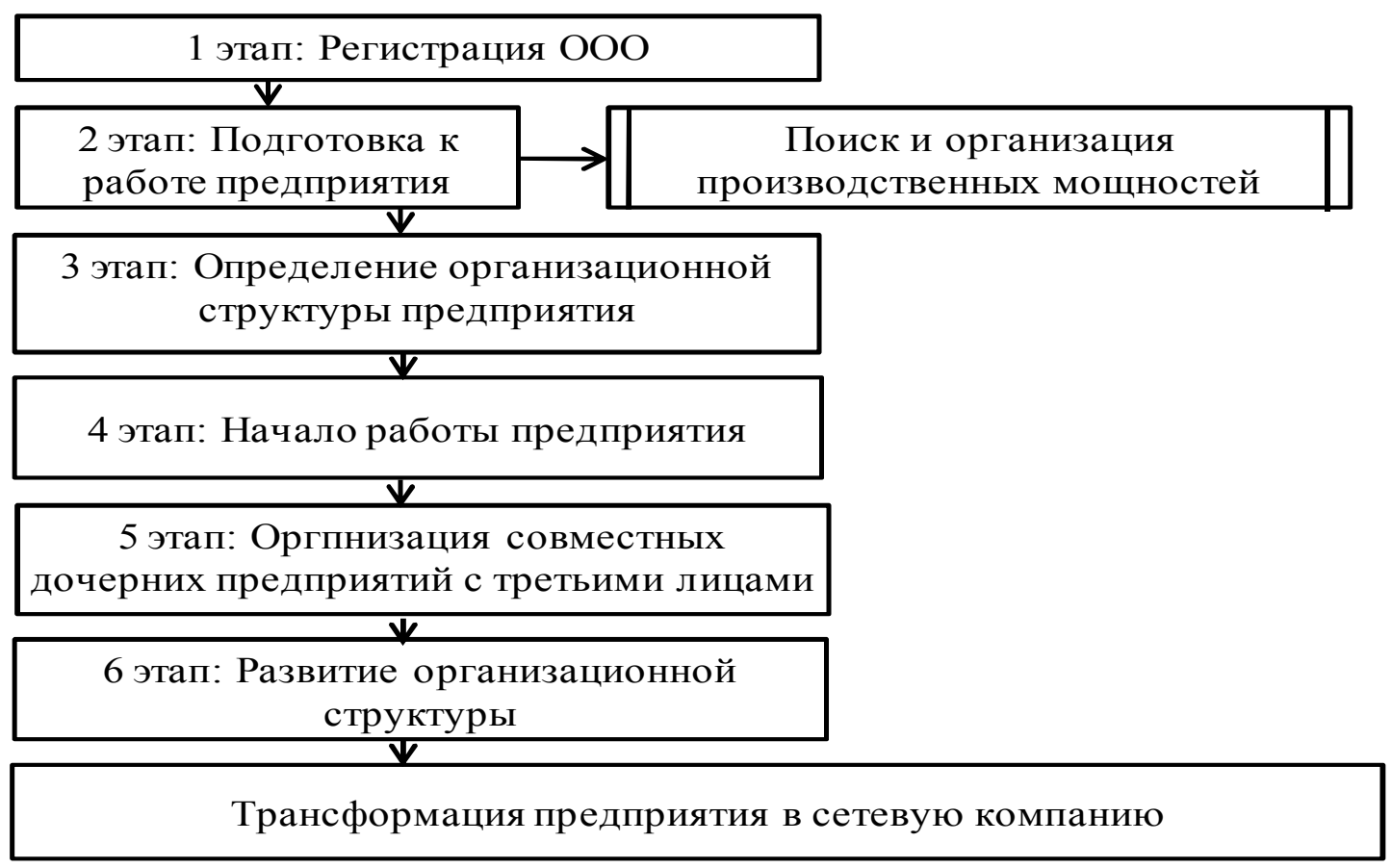

Рис. 7. Этапы развития инновационно-внедренческого предприятия 
Множество разнообразных организационных структур инновационных предприятий, встречающихся в реальной практике, можно свести к нескольким видам, предусматривающим различные варианты распределения ответственности, выполняемых функций и работ, специализации и кооперирования. Различают функциональный, тематический и смешанный виды организационных структур инновационных предприятий.

Для малого инновационно-внедренческого предприятия в сфере стоматологии нами предложена функционально-матричная организационная структура, как наиболее эффективно использующая ресурсы (рис. 8). Данная организационная структура приемлема для холдинговой компании, в которую в будущем трансформируется малое инновационно-внедренческое предприятие по мере развития проектов на созданных совместно с третьими лицами дочерних предприятиях. Дочерние предприятия, находясь в подчинении у холдинговой компании, будут иметь более простую линейную организационную структуру с минимальным количеством сотрудников и отделов, необходимых лишь для функционирования проекта (рис.9). Их цель - выполнять задания от холдинговой компании, связанные с производством инновационных продуктов и т.д.

Из предложенной на рис. 8 схемы организационной структуры инновационно-внедренческого предприятия совет учредителей является высшим органом, контролирующим работу директора компании, решающим, куда направлять часть чистой прибыли, а также занимающийся поиском средств финансирования предприятия. Директор компании, находясь в прямом подчинении у совета учредителей, занимается поиском финансирования предприятия из внешних источников (грантообразующие фонды, кредиты), а также руководит подсистемами, сформированными на предприятии. В каждой подсистеме назначается старший специалист, руководящий деятельностью остальных специалистов, при этом он работает наравне с другими специалистами в своей подсистеме. Каждая инно- 
вационная идея представляет собой проект, за которым закрепляется руководитель со стоматологическим образованием для знания особенностей данной сферы. Специалисты из подсистем, привлеченные к работам по инновационным проектам, не подчиняются полностью руководителю проекта, а действуют в рамках двойного подчинения (подчиняясь также старшему специалисту из подсистемы). На руководителя проекта возлагаются обязанности квалифицированного руководства творческими инновационными процессами и ходом выполнения работ по проектам, а организацию реализации всех этих решений обеспечивают руководители подсистем (старшие специалисты).

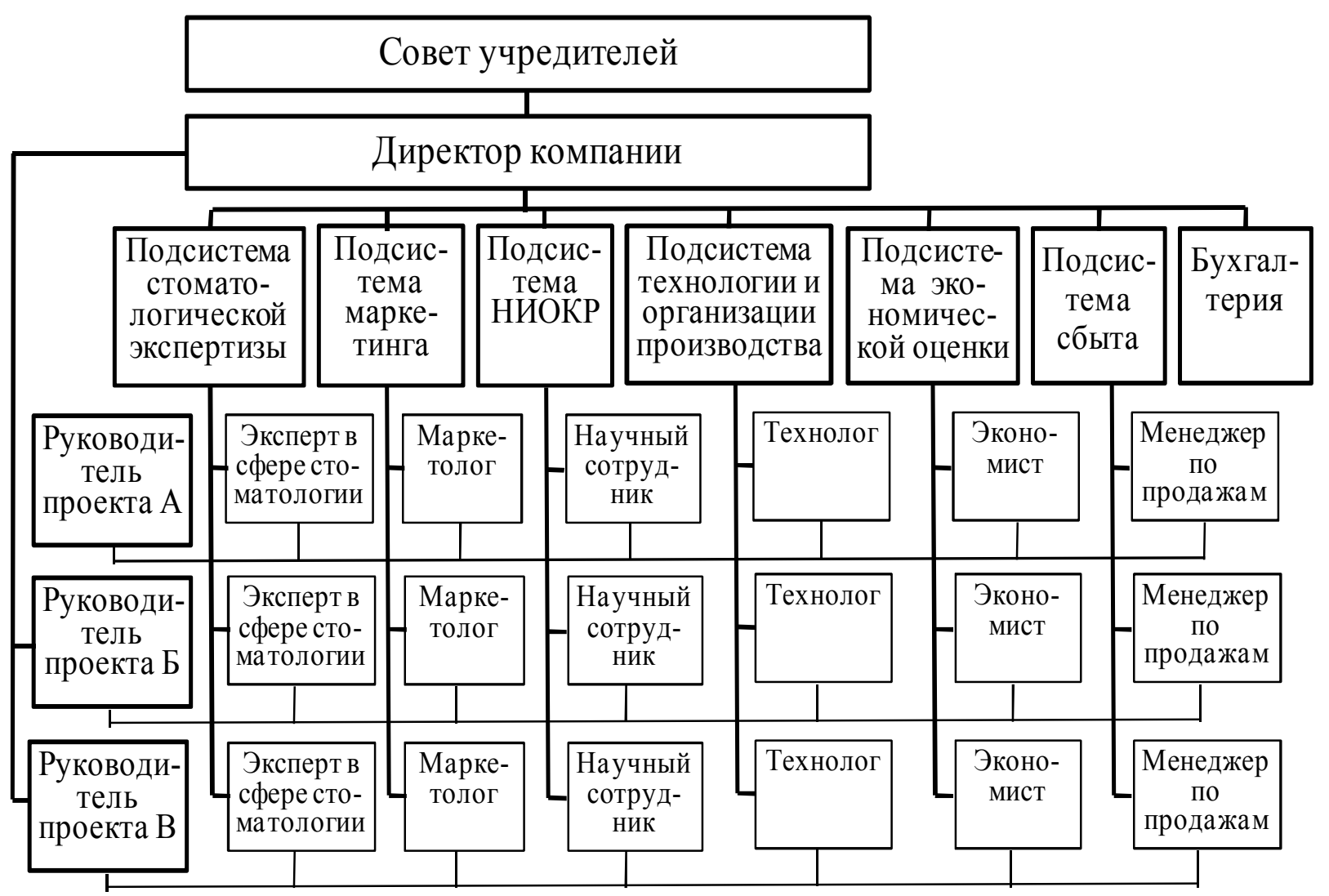

Рис. 8. Функционально-матричная организационная структура работы инновационно-внедренческого предприятия

Подсистема по стоматологической экспертизе включает в себя штат экспертов в области стоматологии, занимающихся поиском и отбором инновационных идей и стоматологических разработок. 


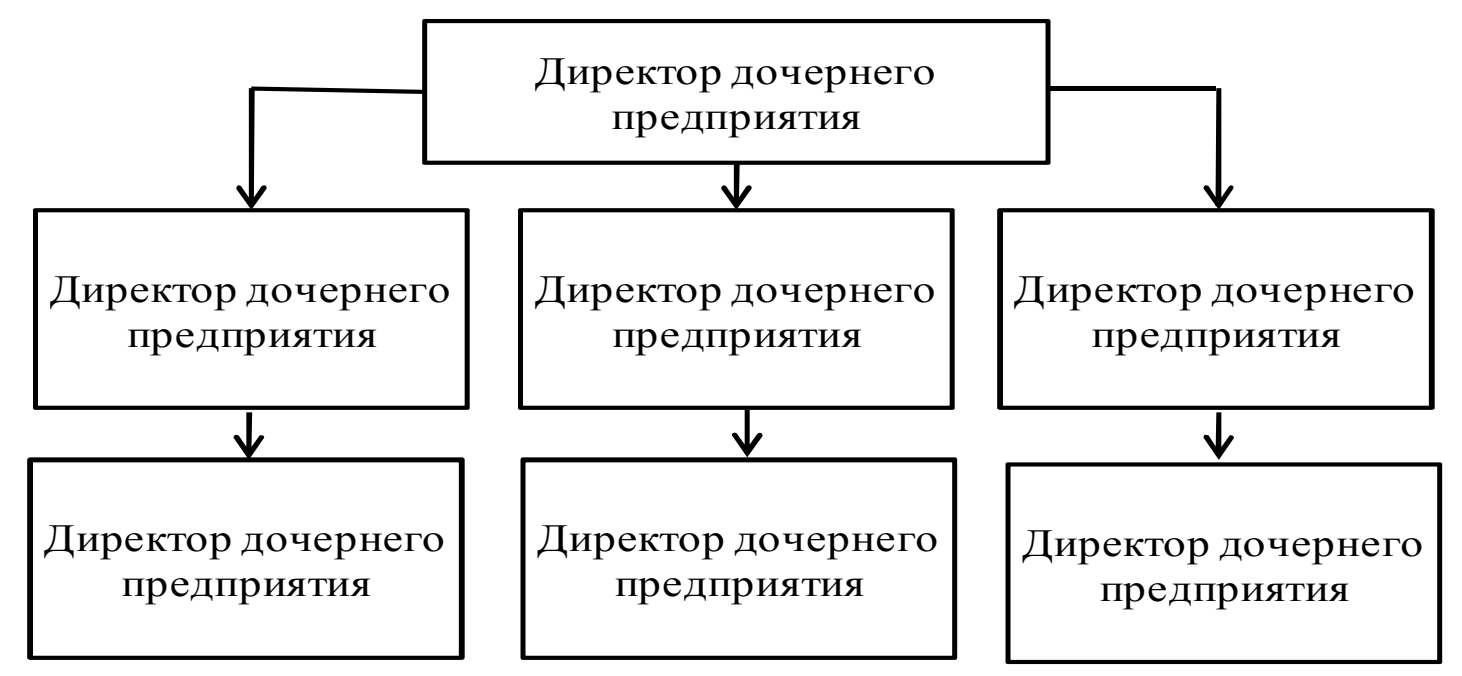

Рис. 9. Линейная организационная структура работы инновационно-внедренческого предприятия

Подсистема по маркетингу включает в себя штат маркетологов и занимается маркетинговыми исследованиями, исследованием рынка стоматологии, бенчмаркингом, исследованием мотивов поведения потребителей, проводит маркетинговую разведку, а также занимается интернет-маркетингом.

Подсистема НИОКР включает в себя штат научных сотрудников (из сферы стоматологии, прикладного материаловедения и др.), выполняющих совокупность работ, направленных на получение новых знаний и практическое применение при создании нового изделия или технологии. Специалисты из этой подсистемы также проводят патентный поиск и готовят документы для сертификации продукции.

Подсистема по технологиям и организации производства включает в себя штат технологов, который готовит соединение всех элементов производственного процесса в единый процесс, обеспечивает их рациональное сочетание и взаимодействие в целях достижения социальной и экономической эффективности производства. Также этот отдел ищет возможности для получения производственных мощностей (взаимодействие со сторонними предприятиями). Данная подсистема создает предпосылки для создания дочерних предприятий. 
Подсистема по экономической оценке состоит из экономистов, оценивающих экономические результаты объектов внедрения на всех этапах. Их задачей также является оценка рисков в каждой из выполняющихся тем.

Подсистема по сбыту включает в себя специалистов по продажам готовой продукции, необходимых при выведении продукта на рынок. На этапе начального функционирования предприятия эта подсистема может не создаваться с целью экономии денежных средств. Бухгалтерия ведет бухгалтерский учет на предприятии.

Предложена концептуальная схема инновационного процесса применительно для новых отечественных инновационных продуктов (рис. 10).

Таким образом, в рамках корпоративной инновационной стратегии предприятия, эксперты в области стоматологии, занимаясь поиском инновационных идей (плотно сотрудничая со специалистами НИОКР, занимающимися патентным поиском и специалистами из подсистемы маркетинга) с последующим участием специалистов из всех подсистем, в конечном итоге, выводят инновационный продукт на рынок. Помогать в этом могут созданные совместно с малым инновационным предприятием дочерние предприятия (с образованием холдинга), выполняя функции производства и др.

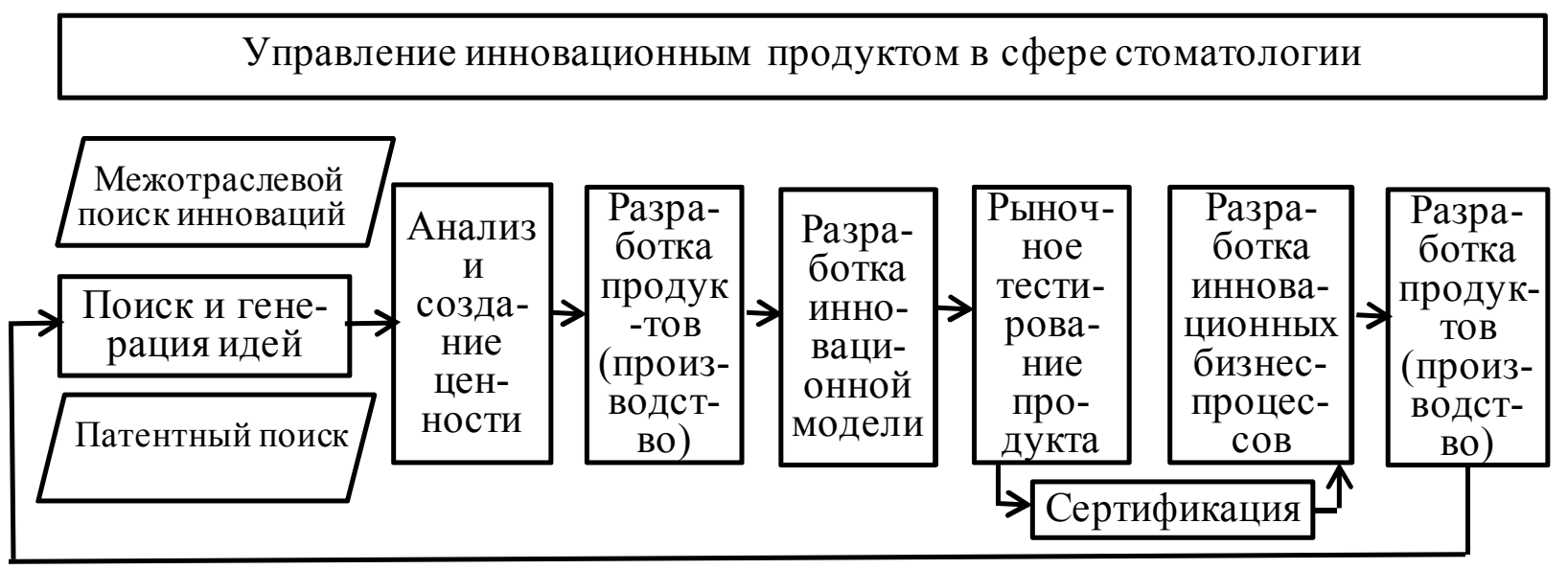

Рис. 10. Управление инновационным продуктом в сфере стоматологии 
В ходе данного инновационного процесса важным является получение необходимых сертификатов. В соответствии с Постановлением Правительства Российской Федерации от 27.11.2012 г. № 1416 «Об утверждении Правил государственной регистрации медицинских изделий» любые медицинские изделия (инструменты, аппараты, приборы, оборудование, материалы и прочие изделия, применяемые в медицинских целях отдельно или в сочетании между собой, а также с иными принадлежностями, необходимыми для применения указанных изделий по назначению, включая специальное программное обеспечение), предназначенные для профилактики, диагностики, лечения и медицинской реабилитации заболеваний, мониторинга состояния организма человека, проведения медицинских исследований, восстановления, замещения, изменения анатомической структуры или физиологических функций организма, предотвращения или прерывания беременности, функциональное назначение которых не реализуется путем фармакологического, иммунологического, генетического или метаболического воздействия на организм человека (далее - медицинские изделия), подлежат государственной регистрации.

Для ввоза, продажи и применения в медицинской практике медицинских изделий его производителю и дистрибьютору необходимо получить следующие документы:

- регистрационное удостоверение - документ, выдаваемый Федеральной Службой Росздравнадзором в сфере здравоохранения и подтверждающий, что медицинское изделие зарегистрировано, то есть информация о нём занесена в Государственный реестр Росздравнадзора, и может быть использовано по своему целевому назначению. Срок действия регистрационного удостоверения не ограничен;

- декларацию соответствия или добровольный сертификат соответствия; 
- лицензию на деятельность по производству и техническому обслуживанию (за исключением случая, если техническое обслуживание осуществляется для обеспечения собственных нужд юридического лица или индивидуального предпринимателя) медицинской техники осуществляется центральным аппаратом Федеральной службы по надзору в сфере здравоохранения в соответствии с основными принципами лицензирования отдельных видов деятельности на территории Российской Федерации (для отечественного производителя).

Для более быстрого выведения инновационного продукта в сфере стоматологии на рынок этап его обязательной сертификации начинается после успешного рыночного тестирования продукта.

\section{3. Бизнес-процессы в деятельности малого инновационно-внедренческого предприятия}

Предложенная в работе схема организации инновационно-внедренческого предприятия представляет собой хозяйственное общество, уставный капитал которого разделен на доли, имеющее необходимые лицензии.

Основным направлениями деятельности инновационно-внедренческого предприятия являются:

- поиск, разработка и внедрение инновационных технологий в стоматологии;

- реализация стоматологических материалов и оборудования собственного производства;

Дополнительным перспективным направлением является стоматологическая практика.

В основе работы малого инновационно-внедренческого предприятия лежат управляющие, операционные и поддерживающие процессы. 
Управляющие - бизнес-процессы, которые управляют функционированием системы. Примером управляющего процесса может служить корпоративное управление и стратегический менеджмент.

Операционные - бизнес-процессы, которые составляют основной бизнес компании и создают основной поток доходов. Примерами операционных бизнес-процессов являются снабжение, производство, маркетинг, продажи и взыскание долгов.

Поддерживающие - бизнес-процессы, которые обслуживают основной бизнес. Например, бухгалтерский учет, подбор персонала, техническая поддержка, административно-хозяйственный отдел.

В данной работе мы считаем необходимым остановиться на некоторых элементах бизнес-процессов, представленных на рис. 11. Важным для работы предприятия является поиск средств финансирования. Одним из вариантов финансирования инновационных идей для предприятия является совмещение стоматологической практики с разработкой и внедрением инноваций в сфере стоматологии. Стоматологическая практика позволяет также апробировать полученные результаты деятельности в рамках инновационных проектов.

Тем не менее, на этапе создания предприятия стоматологическая практика не является приоритетным направлением, требующим внушительных трудозатрат и инвестиций при организации стоматологического приема.

Дополнительными средствами финансирования инновационных идей, реализуемых на предприятии, являются внешние источники: кредитные средства и поддержка грантообразующих фондов. Из внутренних источников, не связанных с основной деятельностью предприятия, является помощь инвесторов в лице учредителей предприятия. Создание каждого инновационного продукта включает в себя следующие общеизвестные этапы: стратегический маркетинг; фундаментальные исследования; прикладные исследования; опытно- 
конструкторские работы; подготовка производства; коммерциализация; освоение производства; промышленное производство; коммерциализация, маркетинг и сбыт. Финансирование данных этапов представлено на следующей схеме (рис. 12).

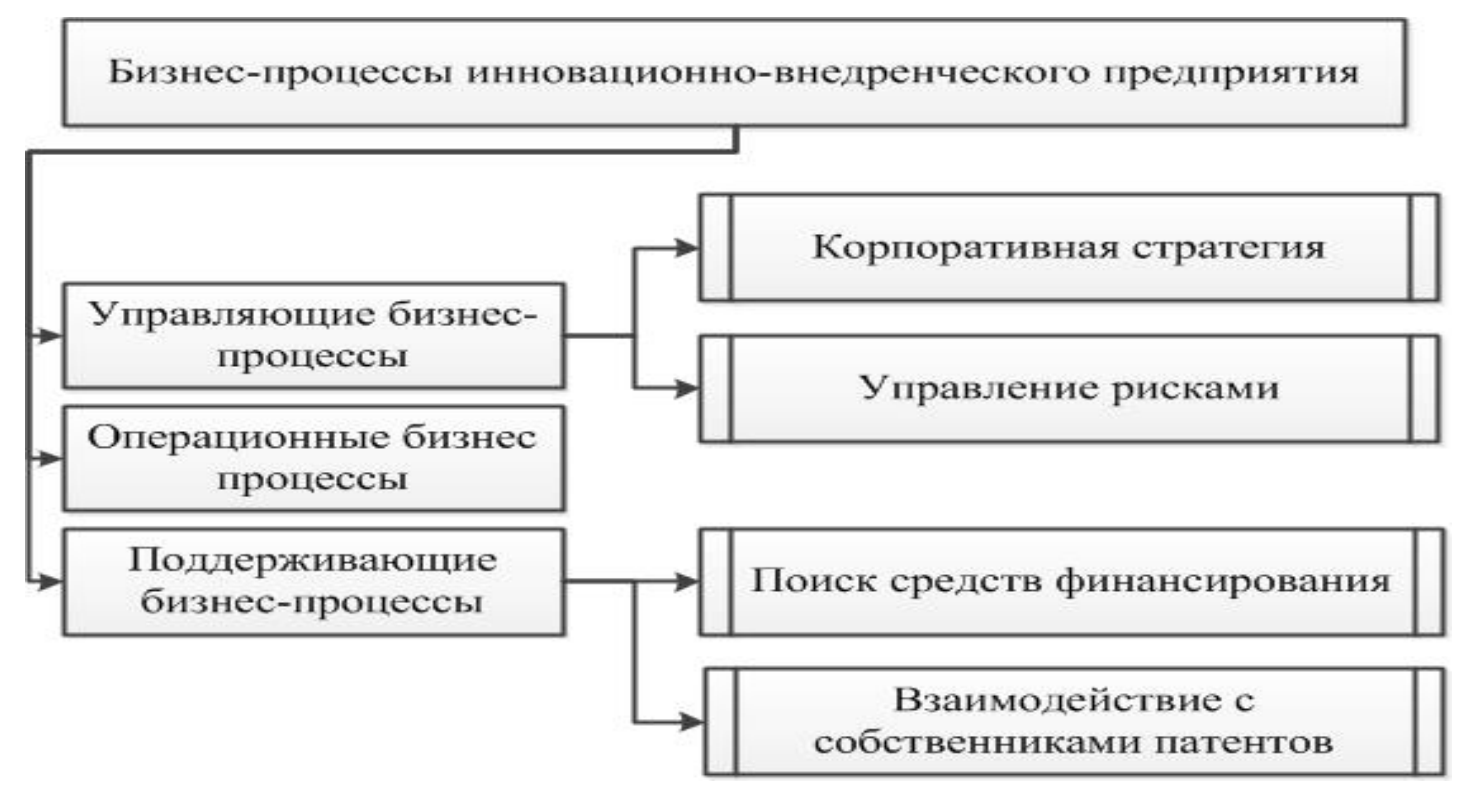

Рис. 11. Бизнес-процессы функционирования инновационновнедренческого предприятия

\begin{tabular}{|c|c|c|c|c|c|c|c|c|}
\hline \multicolumn{9}{|c|}{ ИСТОЧНИКИ ФИНАНСИРОВАНИЯ ИННОВАЦИОННЬХ ПРОЕКТОВ } \\
\hline $\begin{array}{c}\text { страте- } \\
\text { гичес- } \\
\text { кий мар- } \\
\text { кетинг }\end{array}$ & \begin{tabular}{|c|} 
фунда- \\
менталь- \\
ные исс- \\
ледова- \\
ния
\end{tabular} & $\begin{array}{c}\text { приклад- } \\
\text { ные исс- } \\
\text { ледова- } \\
\text { ния }\end{array}$ & $\begin{array}{l}\text { опытно- } \\
\text { конст- } \\
\text { руктор- } \\
\text { ские } \\
\text { работы }\end{array}$ & $\begin{array}{c}\text { подго- } \\
\text { товка } \\
\text { произ- } \\
\text { водства }\end{array}$ & $\begin{array}{c}\text { коммер- } \\
\text { циали- } \\
\text { зация }\end{array}$ & $\begin{array}{c}\text { освое- } \\
\text { ние про- } \\
\text { изводст- } \\
\text { ва }\end{array}$ & $\begin{array}{c}\text { промыш- } \\
\text { ленное } \\
\text { произ- } \\
\text { водство }\end{array}$ & $\begin{array}{l}\text { коммер- } \\
\text { циализа- } \\
\text { ция,мар- } \\
\text { кетинг и } \\
\text { сбыт }\end{array}$ \\
\hline
\end{tabular}

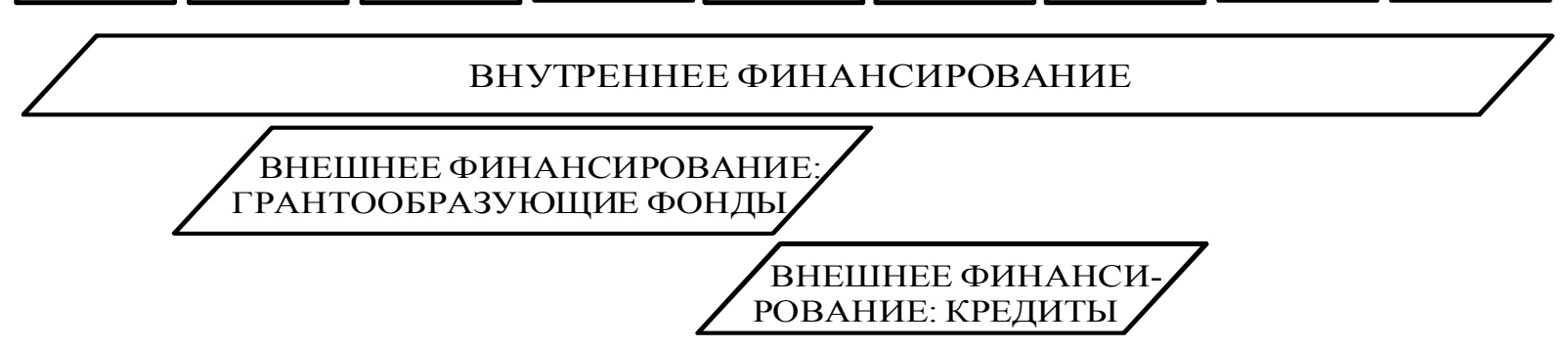

Рис. 12. Источники финансирования инновационных проектов в сфере стоматологии по этапам создания продукта 
По завершении опытно-конструкторских работ предприятие имеет представление о дальнейшей реализации инновационной идеи, поэтому взятие кредитных средств менее рискованно, чем на начальных этапах реализации инновационной идеи. Тем не менее, необходим тщательный контроль идеи подсистемой маркетинга и подсистемой по экономической оценке.

Среди грантообразующих фондов наиболее перспективными являются «Екатеринбургский центр развития предприятий», предоставляющий до 600 тыс. рублей безвозмездно и фонд «Сколково», предоставляющий до 1,5 млн рублей на различных условиях. Кредитование возможно при поддержке «Свердловского областного фонда поддержки предприятий» с выдачей кредитов до 6 млн рублей с низкой процентной ставкой (до 6\% годовых) и Внешэкономбанка (со ставкой кредита до 7,5\% годовых). На этапе коммерциализации инновационного проекта возможна поддержка различных венчурных фондов, а также открытие совместных дочерних предприятий с производителями на различных условиях. На этапе сбыта еще одним перспективным направлением является работа предприятия по государственному заказу, что гарантирует осуществление части заказов при поддержке Правительства РФ.

Данная модель финансирования инновационных идей на малом инновационном предприятии позволяет наиболее эффективно для предприятия внедрить инновационные продукты на рынок в сфере стоматологии.

Основные формы внутреннего финансирования предприятия это:

- прибыль, остающаяся в распоряжении фирмы, которая распределяется на цели накопления и потребления;

- доходы, получаемые от внереализационных операций за вычетом расходов на их осуществление; 
- льготы по налогу на прибыль, которые могут получить организации в соответствии с действующим законодательством;

- внесение собственных средств учредителями предприятия [45].

На этапе создания предприятия оно не может получать прибыль от инновационных идей, поэтому в состав учредителей необходимо включить инвесторов, обладающих возможностью инвестировать в инновационные идеи и разработки, а также в покупку оборудования и помещений.

Предпосылкой к созданию предприятия является использование идеи по изготовлению отечественной плазмокерамики для нужд стоматологии, которая имеет высокие шансы на реализацию и может принести прибыль. Тем не менее, это не единственная идея, которой планирует заниматься предприятие. В некоторых случаях в ходе патентного поиска малому инновационному предприятию могут встретиться полезные ему наработки. Для использования чужого патента возможны следующие формы взаимодействия с собственником данного патента:

- покупка патента;

- использование патента в рамках лицензионного договора;

- создание совместного дочернего предприятия для участия в проекте.

Продажа патента на изобретение, полезную модель и промышленный образец осуществляется путем заключения договора отчуждения патента. Договор, по которому происходит уступка патента, обязательно должен пройти государственную регистрацию в Роспатенте. Продолжительность такой регистрации составляет от 2 месяцев.

Лицензию на использование патента может получить любое лицо, заключившее соответствующий договор с правообладателем. 
В рамках данного договора правообладатель предоставляет пользователю разрешение на использование патента в оговоренных рамках. Условия, предусмотренные в договоре, могут ограничивать территориальное или функциональное использование патента. Срок действия лицензионного договора, помимо самого договора, ограничивается сроком действия самого патента. Покупка патента или использование его по лицензионному договору позволяют пропустить большую часть фундаментальных и прикладных исследований, максимально быстро переходя к опытно-конструкторским работам. Целесообразность такого решения на предприятии контролируется подсистемами стоматологической экспертизы, маркетинга, НИОКР, технологиям и организации производства и экономической оценки.

Финансирование покупки патента или лицензии на патент осуществляется собственными средствами предприятия. Если обнаруженные в ходе поиска патенты утратили свое действие, предприятие может свободно использовать его для своей деятельности. Создание совместного дочернего предприятия с патентообладателем особенно полезно, если это юридическое лицо, имеющее собственные производственные мощности, готовое поучаствовать в проекте с целью диверсификации деятельности этого предприятия.

Управление рисками или риск-менеджмент (англ. risk management) - процесс принятия и выполнения управленческих решений, направленных на снижение вероятности возникновения неблагоприятного результата и минимизацию возможных потерь проекта, вызванных его реализацией [46]. В России существует множество авторских методик управления рисками. Среди известных - методики В.Л. Попова и Н.И. Лапина. Общим для всех методик управления рисками являются этапы, согласно которым идентифицированные риски по плану работы с ними подвергаются анализу, после чего предпринимаются шаги, связанные с реагированием на данные риски и мониторинг рисков. Данные этапы могут выполняться по- 
следовательно, параллельно или в смешанном виде. Недостатками всех применяемых методик является затратность методов, требующих сложного аппарата риск-менеджмента [47]. На наш взгляд, малые инновационные проекты в инновационно-внедренческих предприятиях, в связи с ограниченностью финансирования и малым штатом сотрудников, требуют применения наиболее простой методики управления рисками. В ходе реализации проекта и выхода на этап производства, методика управления рисками может быть выбрана более сложной с формированием штата риск-менеджеров и выделения на это дополнительных средств. Наиболее удобной является смешанная система риск-менеджмента, состоящая из последовательных этапов с возможностью их перекрещивания для лучшей мобильности при реагировании на риски (отражены в методике Попова, повторяющей ANSI/PMI 99-001-2004).

По каждому этапу риск-менеджмента нами выбраны наименее затратные по времени, при этом максимально эффективные методы, перечисленные далее. Система управления рисками на инновационно-внедренческом предприятии имеет проектную направленность. Для каждой инновационной идеи существуют свои риски, которые анализируются отдельно. Для эффективного управления рисками в каждой реализуемой инновационной идее построена общая модель организации риск-менеджмента (рис. 13). Результатом подготовки к планированию управления рисками для каждой инновационной идеи, реализуемой на предприятии, является составление плана, который включает в себя следующие этапы:

- идентификация рисков: составление групп общих и специфических рисков, составление иерархической структуры рисков, составление резерва на реагирование на риски, список значимых рисков, описание причин возникновения рисков;

- качественный анализ рисков: проведение подробного SWOT анализа с выводами; 
- количественный анализ рисков: метод корректировки нормы дисконта, анализ чувствительности, оценка безубыточного объема;

- планирование реагирования на риски: бюджетирование;

- мониторинг управления рисками [47, 48].

Управление рисками проводит подсистема экономической оценки, сотрудничая с другими подсистемами.

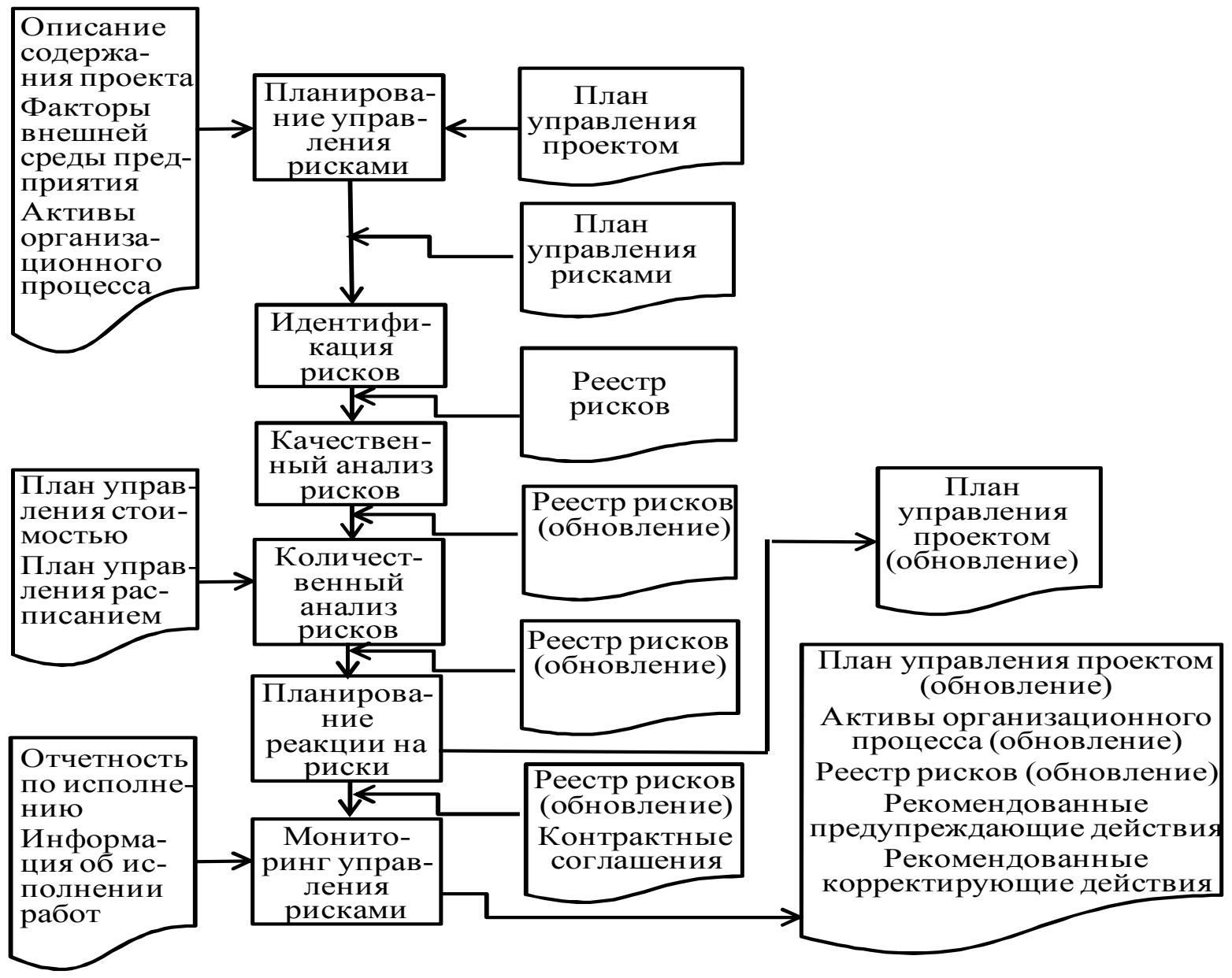

Рис. 13. Модель организации риск-менеджмента

На наш взгляд, целесообразно рассматривать риски по каждой реализуемой инновационной идее, рассчитывая этап коммерциализации, маркетинга и сбыта готовой продукции, так как все предшествующие этапы являются затратными и только последний приносит прибыль. По мере выхода на данный этап все расчетные данные постоянно пересматриваются, обновляя прогнозы на будущий период, 
после чего директором предприятия с одобрения совета учредителей принимаются необходимые управленческие решения о целесообразности поддержания каждого инновационного проекта на предприятии. Тем не менее, для оперативного проектного риск-менеджмента необходимо идентифицировать общие внешние и внутренние специфические риски, присущие для инновационных проектов в стоматологии. Общие внешние риски: (политические, кредитные, инвестиционные и др.):

- риск, связанный с нестабильностью экономического законодательства и текущей экономической ситуации, условий инвестирования и использования прибыли (рост НДС, темпа инфляции, снижение доходов у населения);

- внешнеэкономический риск (возможность введения ограничений на торговлю и поставки, закрытия границ и т.д.);

- неопределенность политической ситуации, риск неблагоприятных социально-политических изменений в стране или регионе;

- неполнота или неточность информации о динамике техникоэкономических показателей, параметрах новой техники и технологии;

- колебания рыночной конъюнктуры, цен, валютных курсов и тому подобное;

- неопределенность природно-климатических условий, возможность стихийных бедствий;

- производственно-технологический риск (аварии и отказы оборудования, производственный брак и т.д.);

- неопределенность целей, интересов и поведения участников;

- неполнота или неточность информации о финансовом положении и деловой ситуации предприятий-участников (возможность неплатежей, банкротств, срывов договорных обязательств).

Данные риски имеют высокое влияние на реализацию проекта, однако их вероятность возникновения сравнительно невысока. 
Составим список основных групп возможных внутренних специфических рисков, характерных для каждого инновационного проекта:

- риски необеспечения инновационного проекта достаточным уровнем финансирования;

- маркетинговые риски текущего снабжения ресурсами, необходимыми для реализации инновационного проекта;

- маркетинговые риски сбыта результатов инновационного проекта;

- риски неисполнения хозяйственных договоров (контрактов);

- риски возникновения непредвиденных затрат и снижения доходов;

- риски усиления конкуренции;

- риски, связанные с недостаточным уровнем кадрового обеспечения;

- риски, связанные с обеспечением прав собственности на инновационный проект, и др.

Основной проблемой при развитии инновационных идей является правильный выбор маркетинговой стратегии. Наиболее подходящей для рассматриваемого предприятия, по отношению к его инновационным идеям, маркетинговой стратегией для продвижения нового стоматологического материала является стратегия проникновения на рынок. Данная стратегия будет использоваться почти для любого разрабатываемого инновационного продукта в стоматологии, так как рынок стоматологических материалов и оборудования уже захвачен зарубежными производителями и необходимо их вытеснение максимальным присутствием нового инновационного товара на рынке в максимально быстрые сроки.

Основные условия деятельности инновационного предприятия:

- доступ к финансовым ресурсам; 
- доступ к каналам распространения инновационного продукта;

- доступ к производственной базе.

Идея по внедрению плазмокерамики в стоматологии является основной для предприятия в настоящий момент. По аналогии с ней будут выстроены бизнес-процессы по реализации будущих инновационных идей. Модель бизнес-процессов деятельности предприятия по созданию инновационного продукта представлена в табл. 3 . На момент начала деятельности предприятия важным является ускорение перечисленных в таблице этапов для возможности наиболее быстрого перехода к сбыту с целью получения прибыли. Так как организация собственных производственных мощностей является высоко затратной частью работы предприятия, возможно сотрудничество со сторонними предприятиями по техническим заданиям. По мере выхода на этап сбыта, чтобы заинтересовать предприятияпроизводителей, возможно создание с ними дочерних предприятий, о чем говорилось выше. Также возможен вариант передачи части прав предприятию-производителю на дистрибуцию произведенной продукции, например по отдельным регионам. Особенность проведения этапов, предшествующих сбыту предполагает проведение множество испытаний. Сегодня при работе инновационных предприятий имеется тенденция сотрудничества с вузами для проведения всех необходимых испытаний и подготовки образцов к испытаниям. С целью более быстрого получения необходимых лицензий и сертификатов на инновационные продукты, что очень важно в медицине и, в частности, в стоматологии, в ходе проведения испытаний предлагается сотрудничество с предприятиями, имеющими лицензии для выдачи необходимых сертификатов.

Одной из таких организаций в России является Центральный Научно-исследовательский Институт Стоматологии (ЦНИИС). С момента своего создания в 1962 году ЦНИИС координирует научную деятельность по вопросам стоматологии, проводимую в научных, учебных и лечебных учреждениях страны. 
荬

\begin{tabular}{|c|c|c|c|c|c|c|}
\hline & 离 & \pm & 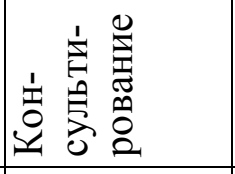 & & 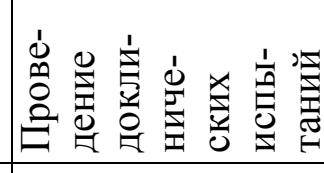 & 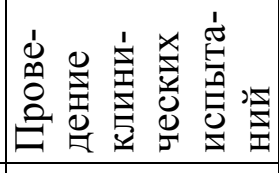 \\
\hline & 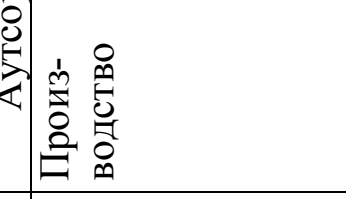 & 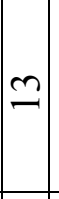 & & & 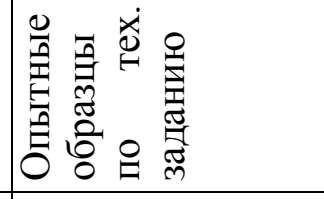 & 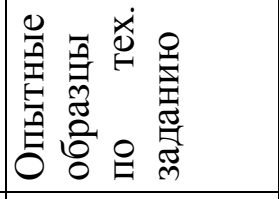 \\
\hline & 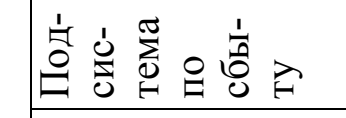 & 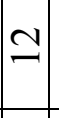 & & & & \\
\hline & 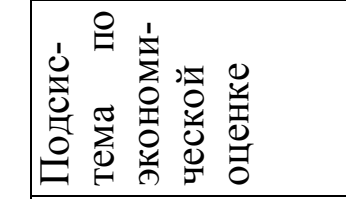 & $=$ & 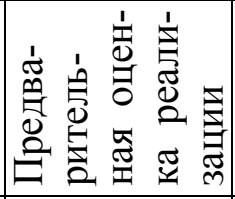 & 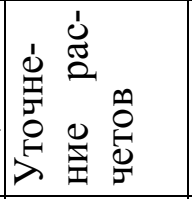 & 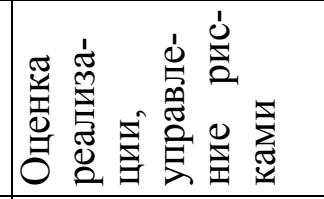 & 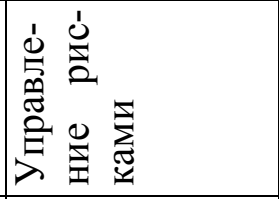 \\
\hline & 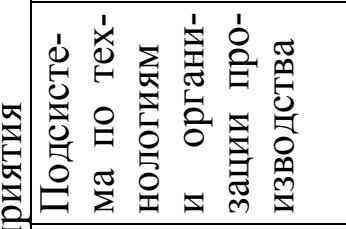 & 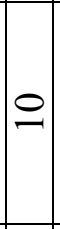 & 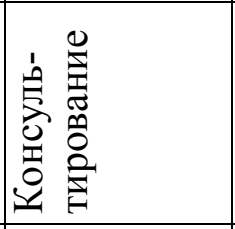 & 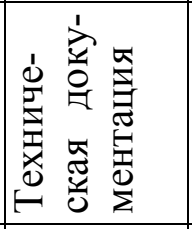 & 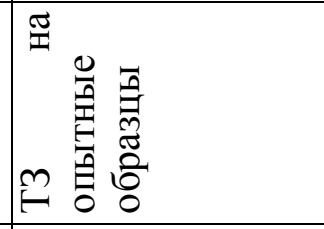 & 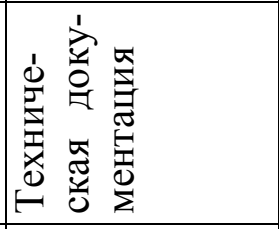 \\
\hline & 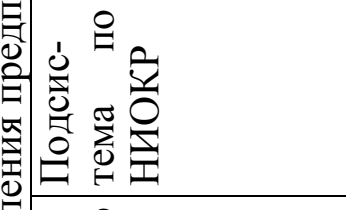 & $a$ & 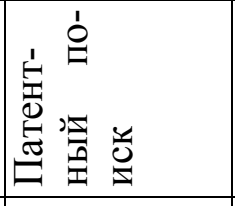 & 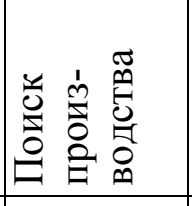 & 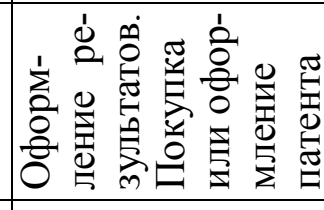 & 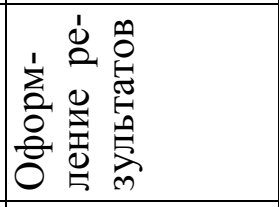 \\
\hline & 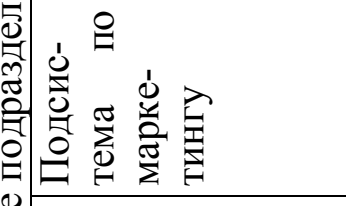 & $\infty$ & 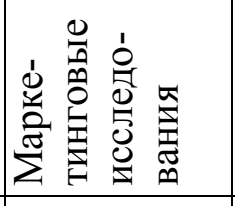 & 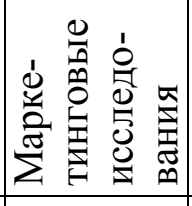 & 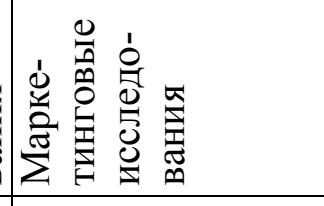 & 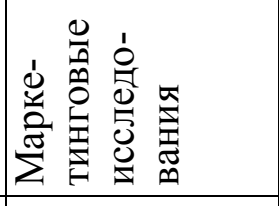 \\
\hline & 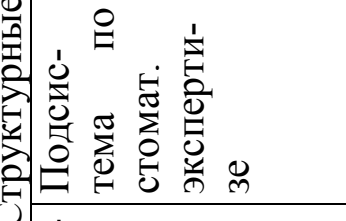 & $r$ & 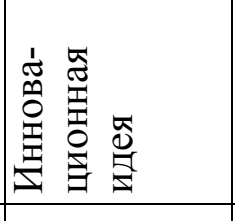 & 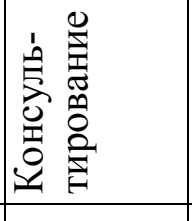 & 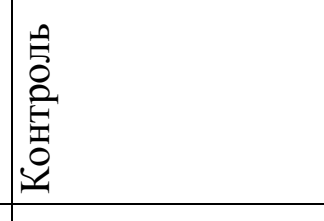 & 是 \\
\hline & 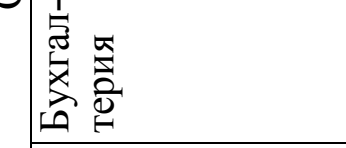 & & 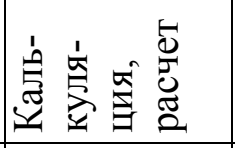 & 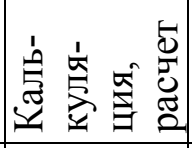 & 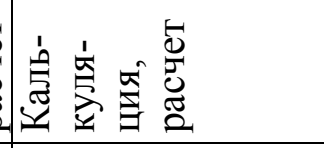 & 点离芯导 \\
\hline & 点咅 。 & $\ln$ & 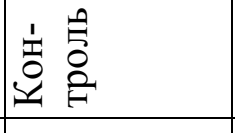 & \begin{tabular}{ll}
1 & 0 \\
1 & 0 \\
0 & 0 \\
& 0 \\
\cline { 1 - 1 }
\end{tabular} & $\begin{array}{ll}1 & 0 \\
\text { 量 } \\
0 \\
0\end{array}$ & 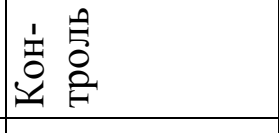 \\
\hline & 占㺼 & & 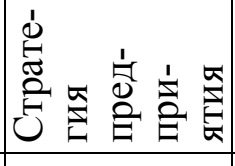 & & 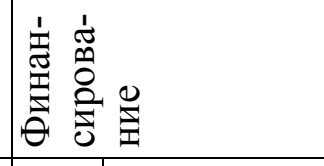 & 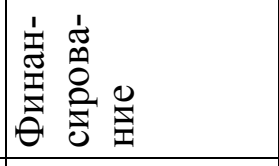 \\
\hline & 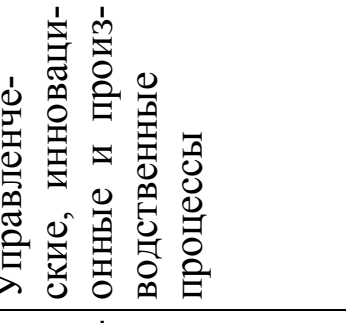 & & 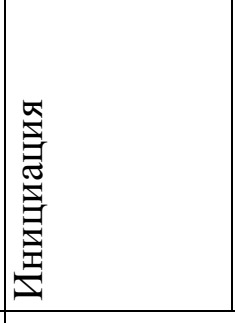 & 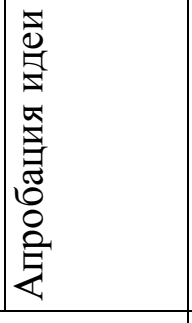 & 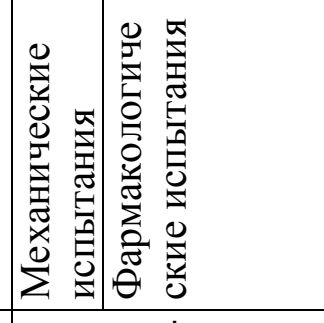 & 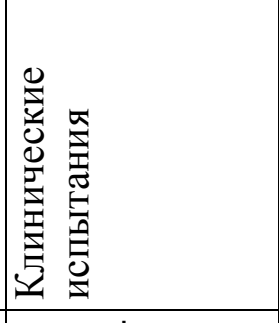 \\
\hline & 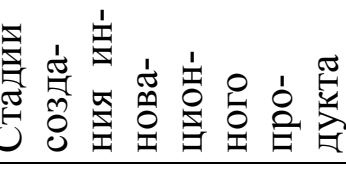 & & 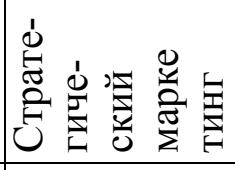 & & 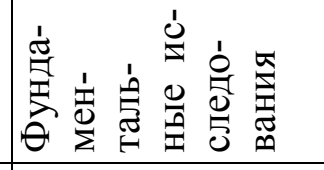 & 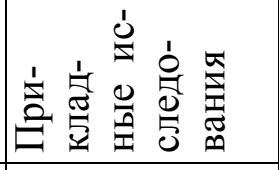 \\
\hline & 年 & - & - & & $N$ & $m$ \\
\hline
\end{tabular}




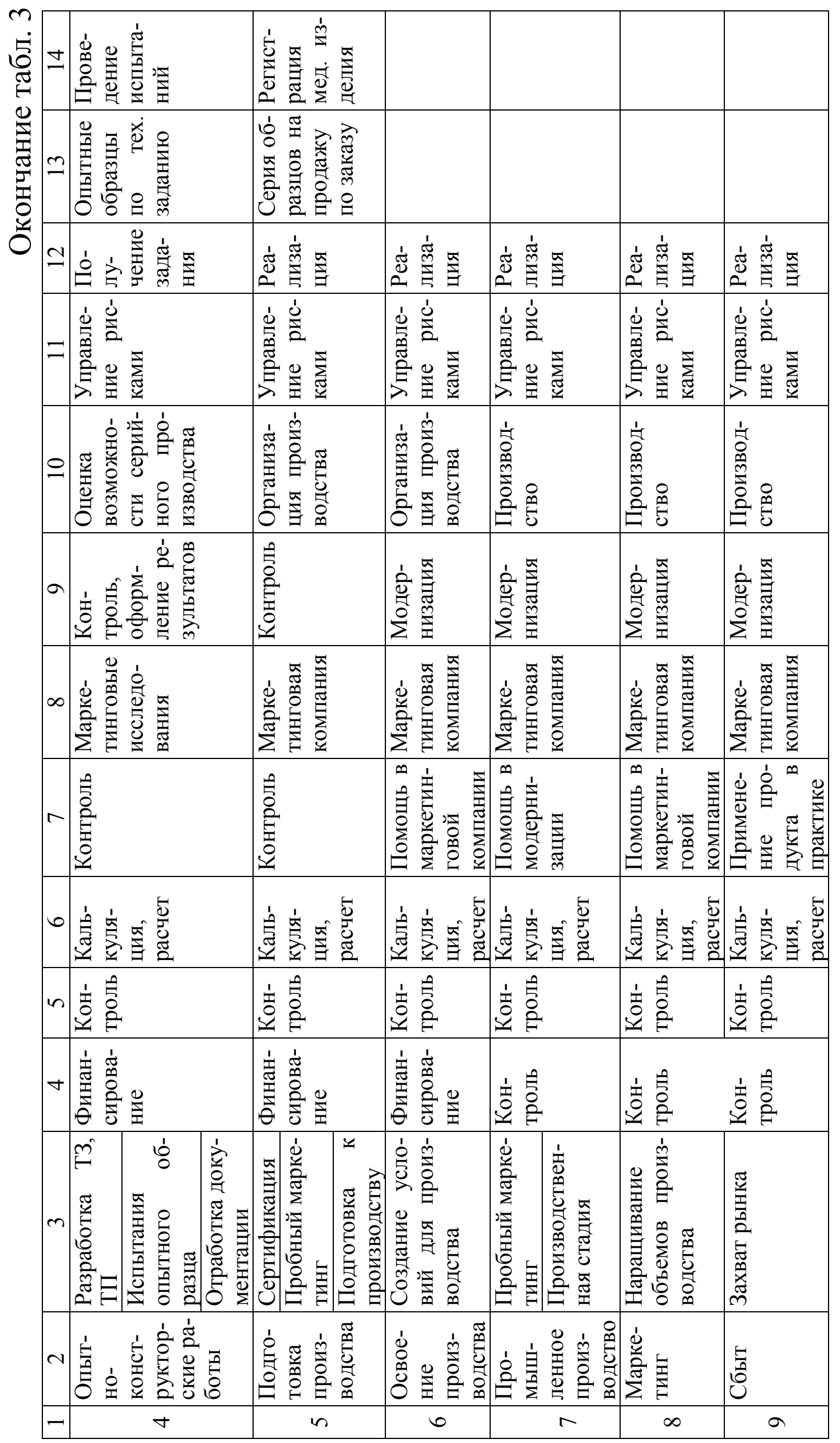


При поддержке правительства РФ данное предприятие, имея в своем распоряжении лаборатории, проводит все необходимые испытания и занимается регистрацией медицинских изделий. Для регистрации медицинского стоматологического оборудования испытания имеют свою специфику. Одной из компаний в России, имеющих опыт в данной сфере, является компания «МИП», расположенная в Москве.

Таким образом, бизнес-процессы малого инновационно-внедренческого предприятия в сфере стоматологии должны иметь определенную мобильность. Важно вовремя рассматривать взаимодействие со сторонними предприятиями с целью экономии времени. При этом немаловажен поиск средств на такое взаимодействие. Показателем эффективности деятельности малого инновационного предприятия является нахождение баланса между этими двумя составляющими.

\section{4. Маркетинговый анализ целесообразности создания малого предприятия внедренческой направленности в стоматологии на базе существующей инновационной бизнес-идеи}

Важным для возможности проверки применения любой теории является практический опыт. Рассмотренные в предыдущих разделах элементы организационно-методического обеспечения создания малого инновационно-внедренческого предприятия необходимо апробировать. В качестве объекта апробации речь пойдет о создании предприятия на примере следующей инновационной идеи. Суть ее состоит в том, что плазмокерамика, использующаяся при изготовлении огнеупорных деталей для высокотемпературных печей, а также в военной промышленности, может зарекомендовать себя и в стоматологии в технологиях CAD-CAM. Предварительно необходим маркетинговый анализ перспектив применения данной идеи. Ввиду сложной конъюнктуры рынка стоматологии, невозможно проанализировать его целиком. Проект по внедрению плазмокерамики в стоматологии является первым проектом, с которого предлагается на- 
чать функционирование инновационно-внедренческого предприятия. Сфокусируемся на анализе рынка CAD-CAM материалов в стоматологии. В дальнейшем по мере развития на предприятии последующих инновационных проектов потребуется маркетинговый анализ для каждого проекта, связанный с его спецификой. Внешний вид зубов всегда говорил о здоровье человека и его отношении к эстетической составляющей внешности. Услуги стоматологов остаются востребованными, оставляя весомый потенциал емкости рынка. Российский рынок стоматологических услуг характеризуется двумя очевидными факторами. Первый - превалирование коммерческих предприятий. Второй - уникальность ввиду присутствия так называемого медицинского туризма. При необходимости проведения комплексного лечения, проживающие в городах с высоким уровнем цен, отправляются в регионы с меньшим бюджетом стоматологических услуг. Ввиду фактического перехода медицинских услуг на коммерческую основу, в сфере стала назревать естественная конкуренция. При этом потребитель фактически находится перед выбором наиболее приоритетных услуг, которые позволяет ему его бюджет. По данным опроса граждан Москвы маркетинговым агентством «Альтера-Инвест», в ТОП направлений стоматология остается неизменным лидером с 2010 года (рис. 14).

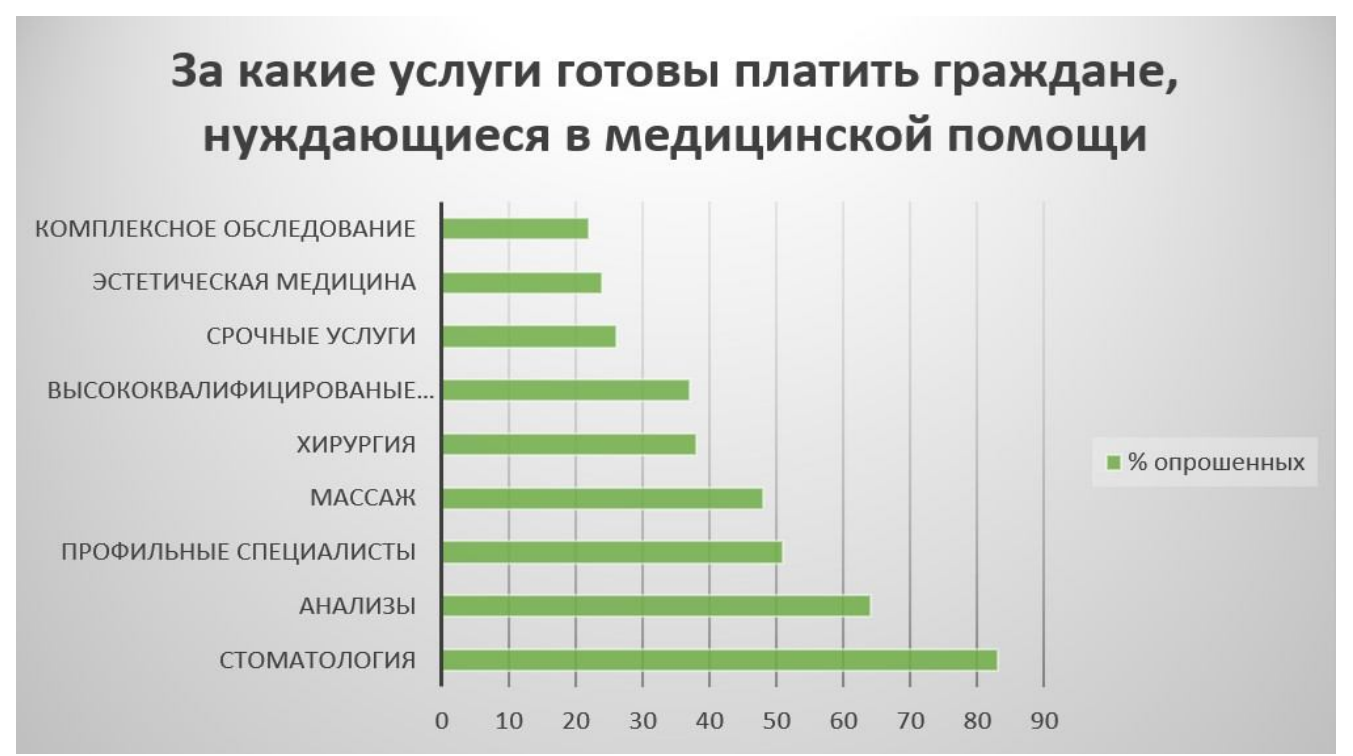

Рис. 14. Результаты опроса граждан Москвы маркетинговым агентством «Альтера-Инвест» [42] 
Сегодня все большее развитие клинической стоматологии при получает протезирование с помощью керамических материалов с применением цифровых технологий. Стоматологические керамические конструкции получаются при помощи технологий CAD-CAM, где в результате компьютерного моделирования готовое изделие получается методом фрезерования из керамических блоков. С помощью CAD-CAM технологий пациентам можно изготавливать большинство терапевтических конструкций, в качестве альтернативе зубным пломбам, а также зубопротезные ортопедические конструкции. Преимуществами таких изделий являются большая долговечность и качество, превосходный эстетический вид, а также точность, так как все процессы, связанные непосредственно с изготовлением конструкций, компьютеризированы, исключая негативное влияние человеческого фактора. Рынок стоматологических CAD-CAM материалов крайне сложно проанализировать из-за наличия частного сектора (до 70\% клиник и зуботехнических лабораторий). Данные, поступающие в государственный реестр, размыты, нередко предоставляются ложные показатели отчетности или информация скрывается вовсе. Статистические данные по изготовленным в клиниках конструкциям отсутствуют. Сегодня Минздравом РФ разработан ряд законов, который поможет в будущем анализировать частный сектор стоматологии. Так, в скором будущем все частные клиники будут обязаны перейти на стандартную кодировку своих услуг с привязывание движения денежных средств. Таким образом, можно будет получить достоверные данные о количестве изготовленных пломб, коронок и т.д. пациентам в каждой клинике. Анализ данных показал, что в Свердловской области зарегистрировано более 250 частных стоматологических клиник и порядка 100 государственных. Еще около $30 \%$ от имеющегося рынка стоматологии клиник не имеют лицензий, поэтому не предоставляют данные отчетности. При этом не во всех клиниках применяются технологии CAD-CAM. Около 50\% клиник работают со старыми технологиями, требующими лишь ручного труда (металлокерамика и т.д.). В г. Екатеринбург имеются около 20 зуботехнических лабораторий, работающих с CAD-CAM 
системами. Еще около 5 лабораторий предоставляют CAD-CAM ycлуги по Свердловской области. Анализ количества устанавливаемых зубных фотокомозитных пломб в клиниках не был проведен, так как предстоит большая работа по смене мышления врачей-терапевтов в пользу выбора керамических пломб, изготовленных методом CADCAM. При анализе рынка услуг ортопедической стоматологии все внимание было нацелено на распространенность керамики из диоксида-циркония, которая уже успешно внедрена в России, и из нее фрезеруются конструкции методом САМ-CAM как с опорой на зубы, так и с опорой на зубные имплантаты.

Подсчет количества единиц ортопедических каркасов на одну клинику из диоксида циркония установлен эмпирическим способом (20\% диоксид циркония от числа всех конструкций). В 50\% всех клиник устанавливаются зубные имплантаты, требующие протезирования. При этом в каждой клинике, работающей с зубными имплантатами также характерно соотношение материалов: 20\% диоксид циркония от числа всех конструкций. В одной стоматологической клинике устанавливается в среднем около 200 зубных имплантатов в год. Количество ортопедических конструкций на живых зубах составляет в среднем 1000 единиц в год на одну клинику. Bсе зубные имплантаты, как в Свердловской области, так и в России в целом, представлены зарубежными производителями (Nobel, MIS, Alpha Bio, OSSTEM, Impro, Bego, Strauman и т.д.). Насчитывается около 100 имплантационных зарубежных систем. В 1990-2000-х гг. на стоматологическом рынке фигурировала отечественная компания КОНМЕТ, выпускавшая зубные имплантаты. В 2015 году данная компания вновь активизировалась, однако ее доля на рынке крайне низкая (менее 1\%) [43].

Рынок материалов для CAD-CAM систем, в частности блоки из диоксида циркония, представлены лишь зарубежными производителями. Это материалы следующих фирм: Cercon (Degudent), Lava (3M), Zirkozahn blanks (Zirkozahn), Hint-Els Zirkon TZP-W, Denzir Premium HiP Zirconia (Etkon), Procera (Nobel Biocare), Hint-Els Zirkon 
TZO-HiP, Digident (Girrbach), KaVo EVEREST ZH-Blanks (KaVo) и др. Доли рынка данных производителей пропорциональны. Каждая зуботехническая лаборатория и стоматологическая клиника выбирает производителя из своих личных предпочтений. Среди отечественных производителей керамики сегодня функционирует новосибирский завод ЗАО «Нэвз-Керамикс», который производит, в том числе, и керамические CAD-CAM заготовки для стоматологии в небольшом количестве. В конце 2017 года на стоматологический рынок официально вышла девелоперская компания Sun Development со своим проектом «Циркон Керамика». Компания хочет производить из японского сырья циркониевые заготовки для CAD-CAM оборудования. Однако сегодня ее доля рынка ничтожно мала. Одной CADСАМ заготовки для систем открытого типа (90\% всех фрезеров) хватает, в среднем, на 20 единиц стоматологических каркасов. Данные по рынку диоксида циркония после проведенных расчетов представлены в табл. 4.

Таблица 4

Данные по рынку диоксида циркония, применяемого в технологиях CAD-CAM в стоматологии

\begin{tabular}{|l|c|}
\hline \multicolumn{1}{|c|}{ Наименование } & Значение \\
\hline $\begin{array}{l}\text { Количество стоматологических клиник всего по Свердловской об- } \\
\text { ласти, шт. }\end{array}$ & 425 \\
\hline $\begin{array}{l}\text { Количество стоматологических клиник с СAD-САМ по Свердлов- } \\
\text { ской области, шт. }\end{array}$ & 213 \\
\hline $\begin{array}{l}\text { Количество зуботехнических лабораторий с СAD-САМ по Сверд- } \\
\text { ловской области, шт. }\end{array}$ & 213 \\
\hline $\begin{array}{l}\text { Количество стоматологических клиник с работой на имплантатах по } \\
\text { Свердловской области, шт. }\end{array}$ & 42600 \\
\hline Имплантатов в год всего по Свердловской области, шт. & 213000 \\
\hline Каркасов САD-САМ в год всего по Свердловской области, ед. & 8520 \\
\hline $\begin{array}{l}\text { Диоксид циркония на имплантатах в год всего по Свердловской об- } \\
\text { ласти, ед. (натуральный объем рынка) }\end{array}$ & 42600 \\
\hline $\begin{array}{l}\text { Каркасы из диоксида циркония на живых зубах в год всего по } \\
\text { Свердловской области, ед. (натуральный объем рынка) }\end{array}$ & \\
\hline
\end{tabular}


Стоимость одного CAD-CAM блока из доиксида циркония, в среднем, составляет 10000 руб. Как было отмечено выше, одного CAD-CAM керамического блока хватает на 20 конструкционных единиц.

Таким образом, себестоимость фрезерования одной единицы каркаса из диоксида циркония (без учета износа оборудования, его обслуживания, синтеризации каркаса в высокотемпературной печи, ФОТ и т.д.) составляет 500 руб. Темп прироста CAD-CAM услуг в год в Свердловской области для простоты подсчета и создания пессимистического прогноза, близкого к реальному взят 0\%. Проведем пессимистический подсчет годового объема рынка диоксида циркония в денежном выражении (табл. 5).

Таблица 5

Годовой объем рынка диоксида циркония, применяемого в технологиях CAD-CAM в стоматологии, в денежном выражении, тыс. руб.

\begin{tabular}{|l|c|}
\hline \multicolumn{1}{|c|}{ Наименование } & Значение \\
\hline $\begin{array}{l}\text { Диоксид циркония на имплантатах в год всего по Свердлов- } \\
\text { ской области }\end{array}$ & 42600 \\
\hline $\begin{array}{l}\text { Каркасы из диоксида циркония на живых зубах в год всего по } \\
\text { Свердловской области }\end{array}$ & 21300 \\
\hline
\end{tabular}

Анализ рынка стоматологических услуг по России в целом в рамках данной работы невозможен ввиду большого количества регионов с населенными пунктами. На сегодня нет прямых аналогов по способу изготовления нового материала методом плазменного напыления. Как было отмечено выше, диоксид циркония, полученный методом изостатического прессования является наиболее близким по свойствам созданному материалу. Все каркасы из диоксида циркония являются однотипными по свойствам. Ниже приведена сравнительная таблица по основным свойствам типичного диоксида циркония и нового материала на основе электрокорунда (табл. 6). 
Таблица 6

Сравнительная таблица по основным свойствам типичного диоксида циркония и нового материала на основе электрокорунда, применяемых в технологиях CAD-CAM в стоматологии

\begin{tabular}{|l|l|l|}
\hline \multicolumn{1}{|c|}{ Показатели } & \multicolumn{1}{|c|}{ Диоксид циркония } & \multicolumn{1}{|c|}{$\begin{array}{l}\text { Плазмокерамика } \\
\text { из электрокорунда }\end{array}$} \\
\hline Прочность & Высокая & Высокая \\
\hline Стоимость & Высокая & Средняя \\
\hline Внешний вид & Высокая эстетика & Высокая эстетика \\
\hline Биосовместимость & Высокая & Высокая \\
\hline Стабильность & $\begin{array}{l}\text { Сомнительная в отдален- } \\
\text { ном периоде }\end{array}$ & $\begin{array}{l}\text { Высокая (данные за 4 года } \\
\text { наблюдений) }\end{array}$ \\
\hline $\begin{array}{l}\text { Возможность нанесе- } \\
\text { ния облицовочного } \\
\text { слоя }\end{array}$ & Есть & Есть \\
\hline $\begin{array}{l}\text { Универсальность кон- } \\
\text { струкций }\end{array}$ & Да & Да \\
\hline $\begin{array}{l}\text { Цельная анатомия } \\
\text { (без облицовки) }\end{array}$ & Есть, с окрашиванием & На этапе разработки \\
\hline $\begin{array}{l}\text { Вес конструкции } \\
\text { Возможность приме- } \\
\text { нения нанонаполни- } \\
\text { телей }\end{array}$ & $\begin{array}{l}\text { Тяжелый, сравним с ме- } \\
\text { Теллом }\end{array}$ & Легкий \\
\hline Пористость & Нет & Есть, за счет пористости \\
\hline
\end{tabular}

Таким образом, разработанная керамика выигрывает у зарубежных аналогов из диоксида циркония практически по всем аналогам. Требуются инвестиции на испытания и подготовку ОКР для изготовления блоков из плазмокерамики под цельноанатомические конструкции. Преимущество материала в виде пористости дает высокий потенциал для применения нанонаполнителей (для изменения цвета блока CAD-CAM и получения высокоэстетичных оптических эффектов). В стоматологии прослеживается четкая склонность покупателя к выбору импортного продукта. Для продвижения отечественной плазмокерамики для следования сложившемуся тренду, 
вероятно, будет выбран бренд, похожий на импортный. Одно из названий: «Алоксдент» (Aloxdent TM). Возможно, в будущем, потребуется организация ОЕМ производства для выхода на региональный и национальный рынки. Таким образом, по результатам проведенного маркетингового анализа по созданию предприятия в стоматологии инновационно-внедренческой направленности можно сделать вывод о благоприятных условиях для его функционирования. В третьей главе более подробно описан сам проект по реализации проекта по созданию и коммерциализации материала на основе плазмокерамики в стоматологии для технологий CAD-CAM.

\section{5. Апробация организационно-экономического обеспечения создания малого инновационно-внедренческого предприятия в стоматологической сфере}

Рассмотрим применение описанных выше элементов организационно-методического обеспечения создания малого инновационновнедренческого предприятия на базе инновационной идеи применения плазмокерамики в стоматологии в технологиях CAD-CAM. На применение данного материала в стоматологии получен патент РФ № 2585238. Применение опыта предприятий, производящих плазмокерамику и использующих его (для целей, не связанных со стоматологией), а также сотрудничество с ними на этапах производства будет способствовать распространению материала в сфере стоматологии на базе рассматриваемого инновационно-внедренческого предприятия (рис. 15).

Проект по внедрению плазмокерамики в стоматологию находится на этапе НИОКР с целью создания образца плазмокерамики с улучшенными свойствами (не требующего нанесения облицовки после фрезерования изделия из CAD-CAM блоков). При этом на основании имеющегося в активах предприятия патента и проведенных разработок есть возможность выпускать материал (после необходи- 
мой сертификации), требующий нанесение облицовочного слоя после фрезерования зубопротезного изделия из полученных CAD-CAM блоков.

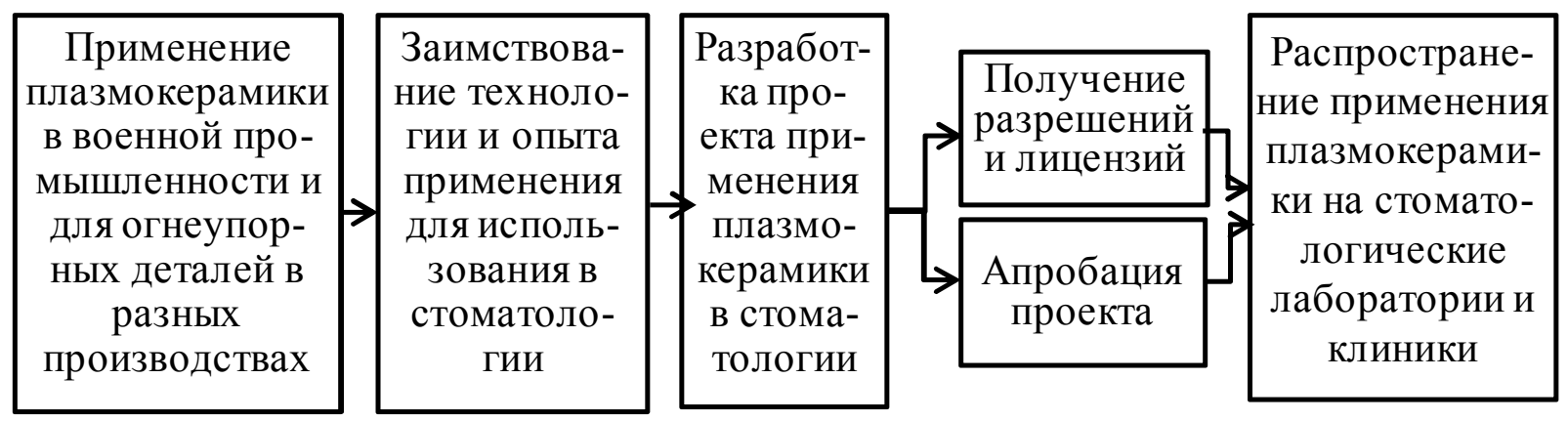

Рис. 15. Концептуальная схема внедрения плазмокерамики

в стоматологию на инновационно-внедренческом предприятии

Большинство зубопротезных конструкций в стоматологии, применяемых сегодня требуют нанесения облицовочного слоя. ОКР направлены на возможность использования нового материала в 100\% всех работ с использованием технологий CAD-CAM в ортопедической стоматологии благодаря усовершенствованию материала с возможностью обрабатывать его без последующей облицовки. Создание малого инновационно-внедренческого предприятия начнется с внедрения данного проекта в сферу стоматологии. На этапах, предшествующих выведению продукта на рынок, предложено сотрудничество с предприятием, занимающимся изготовлением плазмокерамики для огнеупорных печей в городе Екатеринбурге по заказам. В перспективе планируется открытие с данным предприятием на базе созданного малого инновационно-внедренческого предприятия дочерней фирмы. Для учета интересов фирмы-производителя возможна передача фирме-производителю эксклюзивного права на дистрибуцию материала в часть регионов России в рамках функционирования дочерней компании (рис. 16). На этапе внедрения плазмокерамики в стоматологию предприятие начинает свою деятельность. Взаимодействие с собственниками патентов отсутствует, так 
как в активах предприятия имеется свой собственный патент на производство плазмокерамики для стоматологии (рис. 17).

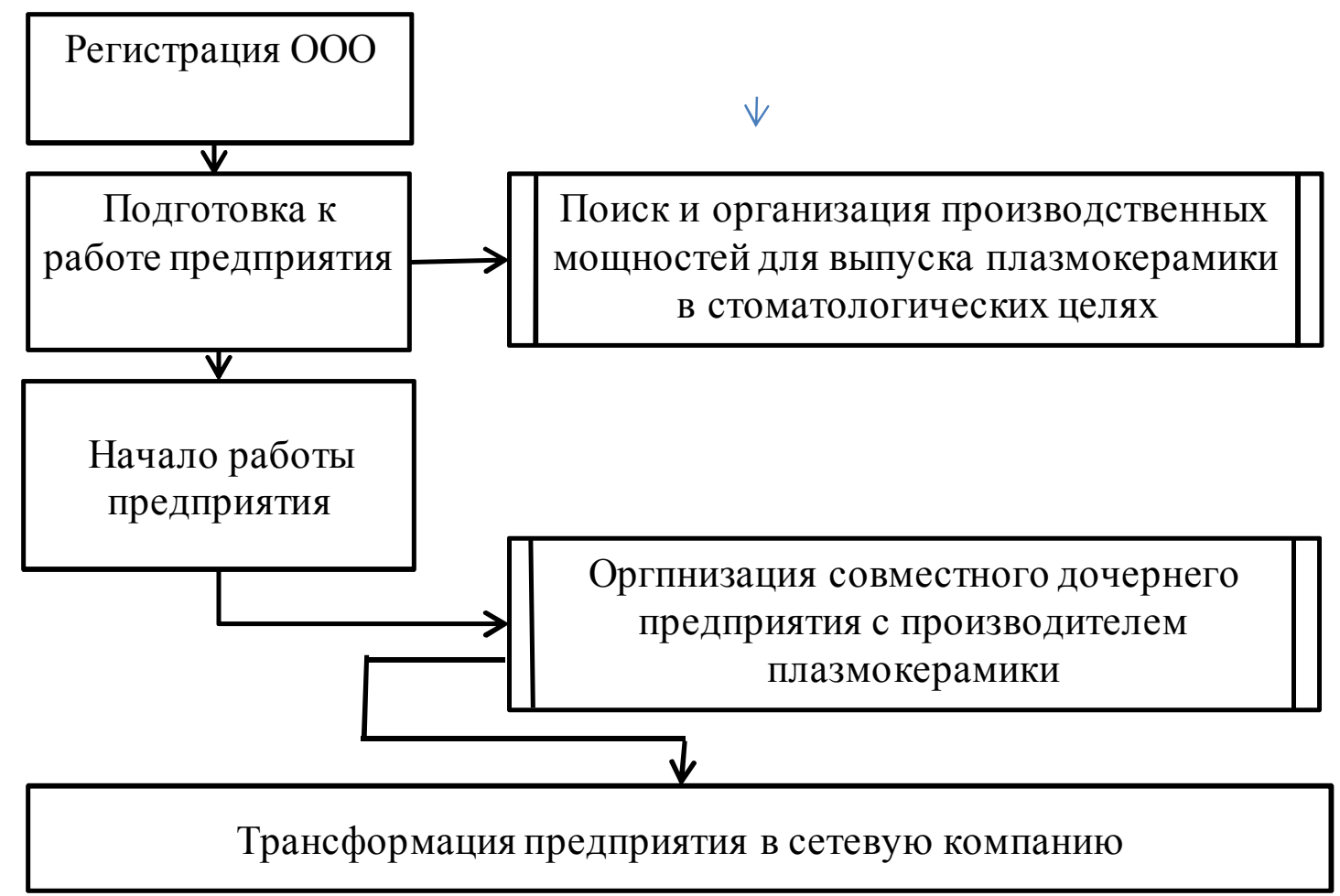

Рис. 16. Этапы развития инновационно-внедренческого предприятия после разворачивания на нем проекта по внедрению плазмокерамики в стоматологию

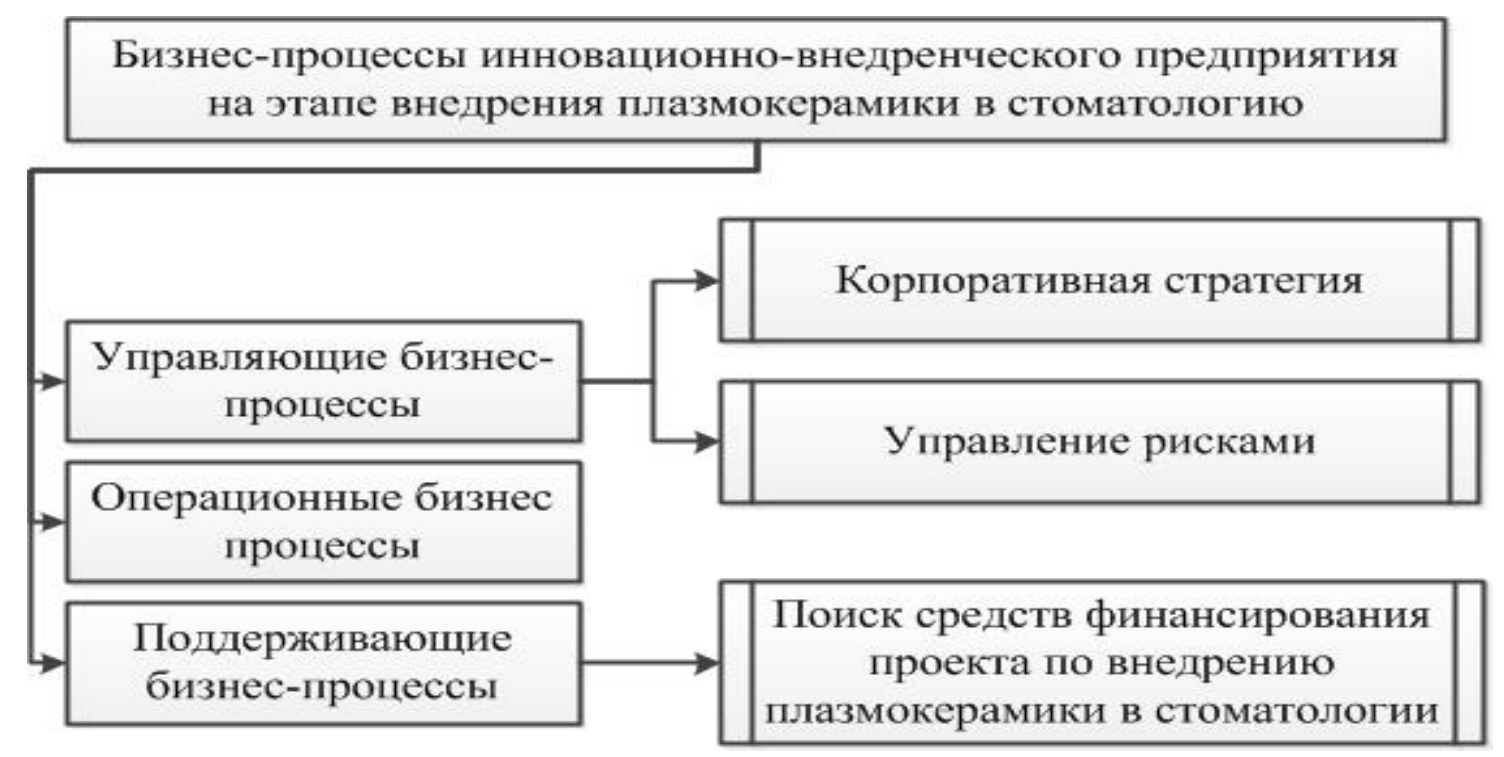

Рис. 17. Организация бизнес-процессов на предприятии, необходимых для реализации его первого проекта 
Наиболее важным для предприятия является поиск средств финансирования для успешной реализации его первого патента. Предложенная ранее общая схема поиска средств для финансирования проекта плазмокерамики в стоматологии выглядит следующим образом (рис. 18).

\begin{tabular}{|c|c|c|c|c|c|c|c|c|}
\hline ИС & ІНИК & $\begin{array}{l}\text { ФИН } \\
\mathrm{A} 3 \mathrm{~N}\end{array}$ & $\mathrm{EPA}$ & КИВ & OMA & & 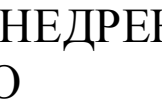 & \\
\hline $\begin{array}{c}\text { страте- } \\
\text { гичес- } \\
\text { кий мар- } \\
\text { кетинг }\end{array}$ & \begin{tabular}{|c|} 
фунда- \\
менталь- \\
ные исс- \\
ледова- \\
ния
\end{tabular} & $\begin{array}{c}\text { приклад- } \\
\text { ные исс- } \\
\text { ледова- } \\
\text { ния }\end{array}$ & $\begin{array}{c}\text { опытно- } \\
\text { конст- } \\
\text { руктор- } \\
\text { ские } \\
\text { работы }\end{array}$ & $\begin{array}{c}\text { подго- } \\
\text { товка } \\
\text { произ- } \\
\text { водства }\end{array}$ & $\begin{array}{c}\text { коммер- } \\
\text { циали- } \\
\text { зация }\end{array}$ & $\begin{array}{c}\text { освое- } \\
\text { ние про- } \\
\text { изводст- } \\
\text { ва }\end{array}$ & \begin{tabular}{|c|} 
промыш- \\
ленное \\
произ- \\
водство
\end{tabular} & $\begin{array}{l}\text { коммер- } \\
\text { циализа- } \\
\text { ция,мар- } \\
\text { кетинг и } \\
\text { сбыт }\end{array}$ \\
\hline
\end{tabular}

ВНУТРЕННЕЕ ФИНАНСИРОВАНИЕ, В ТОМ ЧИСЛЕ ДЕНЬГИ УЧРЕДИТЕЛЕЙ

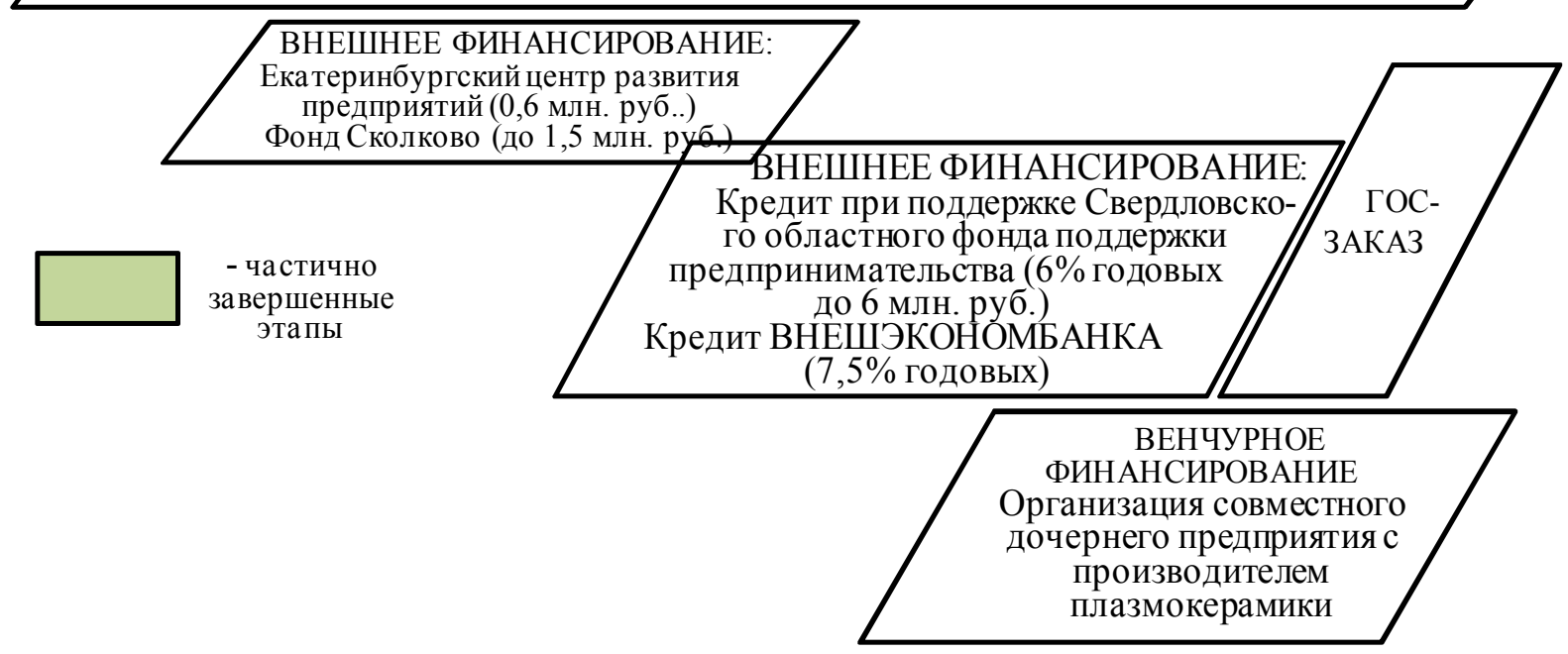

Рис. 18. Схема поиска средств для финансирования проекта плазмокерамики в стоматологии

Календарный план реализации проекта включает в себя на первом этапе (год):

- НИОКР - на условиях договора-подряда - изготовить новый пробный образец CAD-CAM заготовки для фрезерования цельноанатомических конструкций в стоматологии;

- регистрацию товарного знака;

- проведение сертификации продукции в сотрудничестве с ЦНИИС с изготовлением необходимых образцов для фармакологических, механических, доклинических и клинических испытаний. 
Источник финансирования этапа - грант «Екатеринбургского центра развития предприятий» (600 тыс. руб.)

Второй этап (три года):

- подготовка помещений;

- открытие дочернего предприятия вместе с фирмой-производителем;

- закупка оборудования;

- подбор и обучение персонала;

- подготовка и утверждение бизнес-процессов;

- предварительные маркетинговые мероприятия;

- согласование с надзорными государственными органами;

- юридическое оформление.

- запуск производства (20\% производственной мощности)

- внедрение материалов на региональном уровне

- увеличение производства и продаж вдвое со второго года функционирования проекта (40\% производственной мощности).

Источники финансирования второго этапа:

- средства гранта Сколково (1500 тыс. руб);

- кредит банка - при поддержке «Свердловского областного фонда поддержки предприятий» и Внешэкономбанка (3900 тыс. руб);

- собственные средства (до 4879,74 тыс. руб.).

Третий этап (два года):

- увеличение производственных мощностей;

- переход на национальный уровень.

Источники финансирования: ятия);

- собственные средства (реинвестирование прибыли предпри-

- инвестиции извне; 
- кредитные средства (для увеличения показателей финансового левериджа).

Этапы фундаментальных, прикладных исследований и опытноконструкторских работ по созданию плазомкерамики в стоматологии будут выполняться в сотрудничестве с ЦНИИС. Как было отмечено выше, часть проведенных испытаний в рамках существующего патента необходимо продублировать с целью получения в конечном итоге сертификатов на плазмокерамику, требующую облицовочного слоя, а также разрабатываемую плазмокерамику, не требующую облицовки. Опытные образцы для испытаний планируется изготавливать в сотрудничестве с предприятием-производителем плазмокерамики для высокотемпературных печей в городе Екатеринбурге.

На этапе подготовки производства планируется открытие дочернего предприятия вместе с производителем, у которого изготавливались опытные образы по заказам (табл. 7).

При общем объеме инвестиций 10,3 млн руб. текущие затраты нового предприятия составят в первый год второго этапа 3,4 млн руб., далее - 9,7 млн руб. Показатели эффективности инвестиций представлены в табл. 8.

Показатели говорят об экономической целесообразности создания малого инновационного предприятия, первым проектом которого является внедрение инновационной идеи, связанной с применением плазмокерамики в стоматологии.

Качественный анализ рисков проекта на основе SWOT-анализа представлен на рис. 19. 


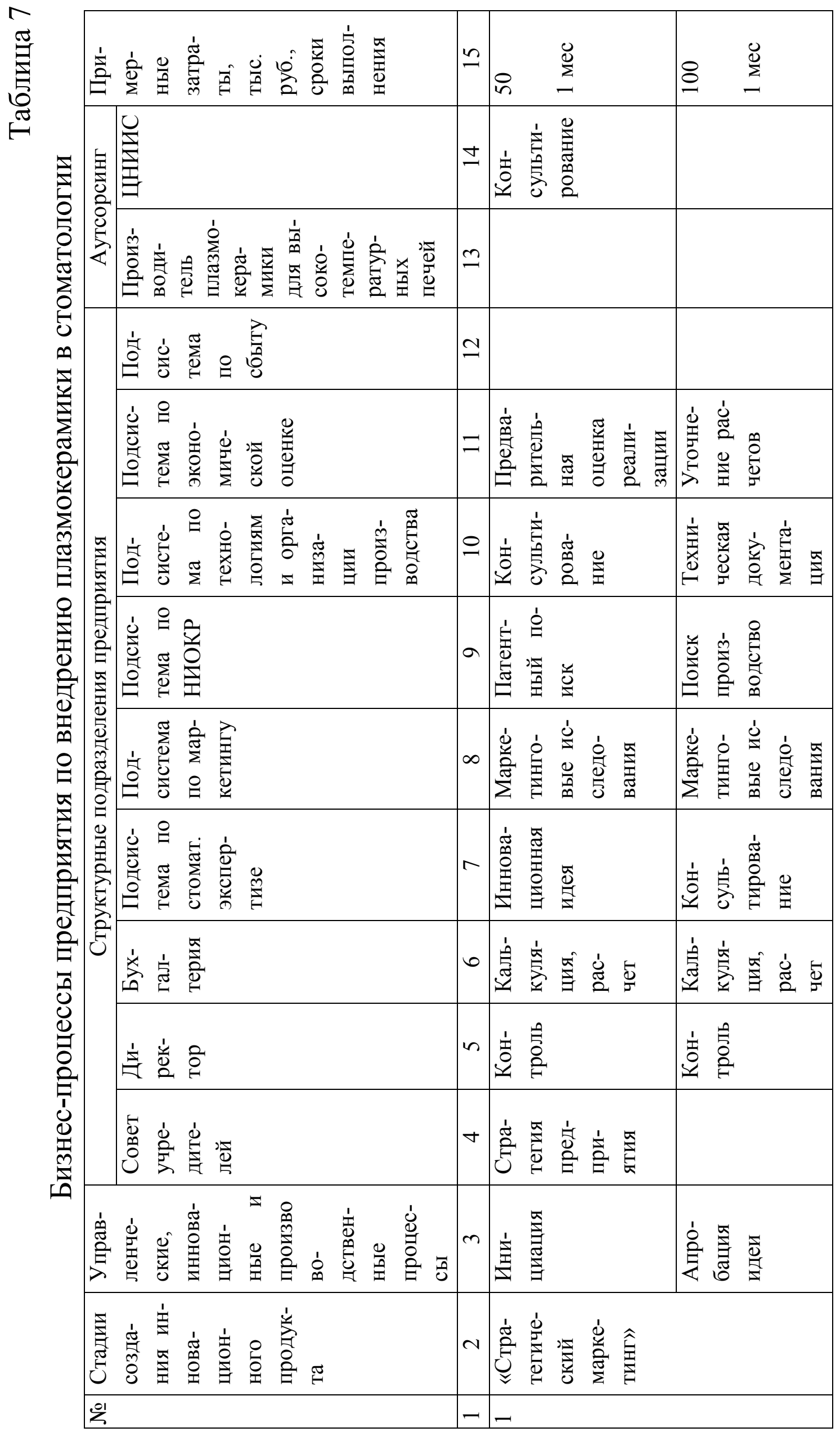




\begin{tabular}{|c|c|c|c|}
\hline 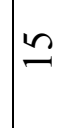 & 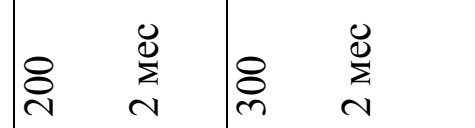 & 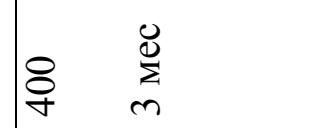 & $\underset{d}{\stackrel{d}{2}}$ \\
\hline \pm & 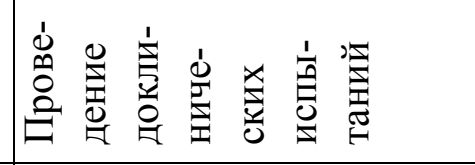 & 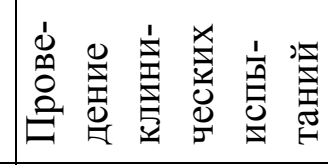 & 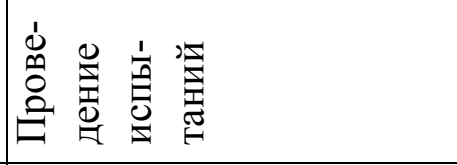 \\
\hline & 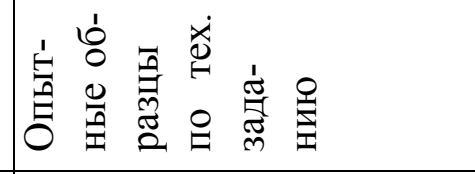 & 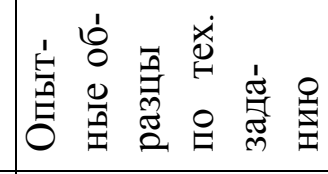 & 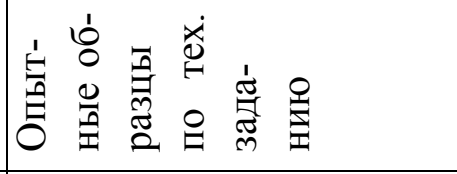 \\
\hline$\simeq$ & & & 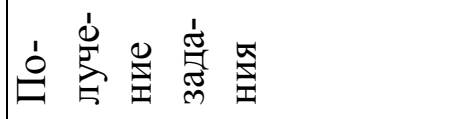 \\
\hline & 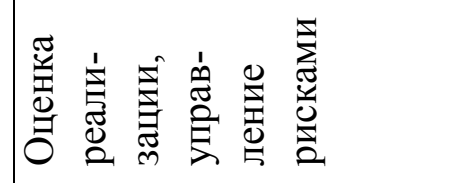 & 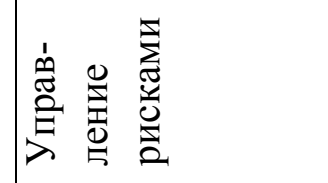 & 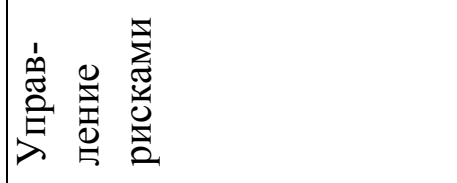 \\
\hline 으 & 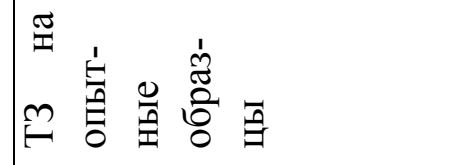 & 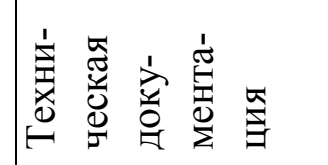 & 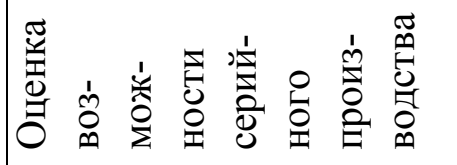 \\
\hline$a$ & 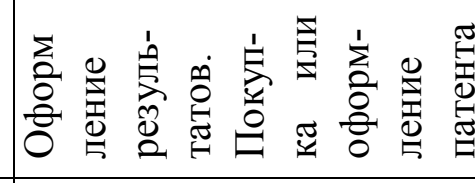 & 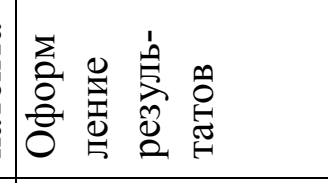 & 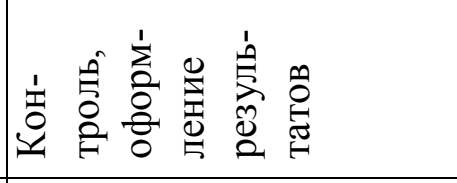 \\
\hline$\infty$ & 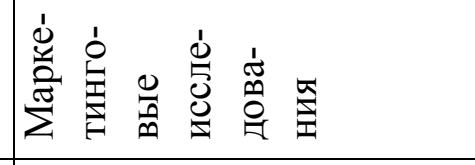 & 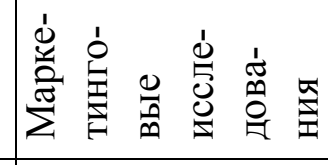 & 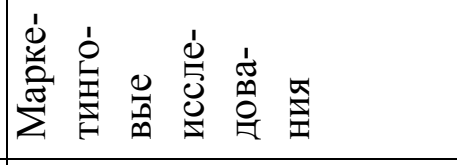 \\
\hline r & 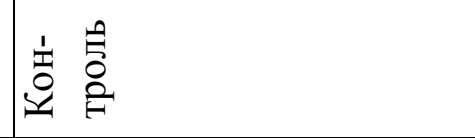 & 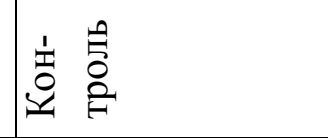 & 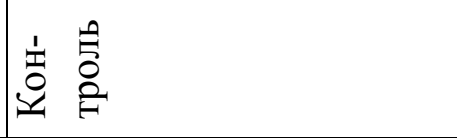 \\
\hline 6 & 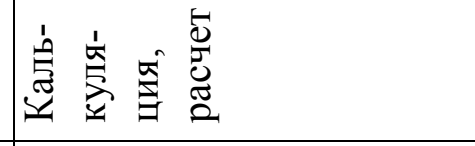 & 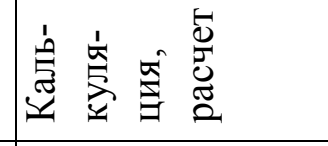 & 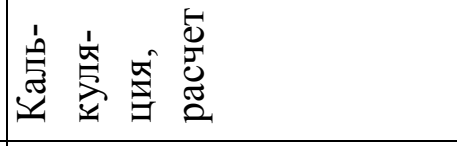 \\
\hline in & 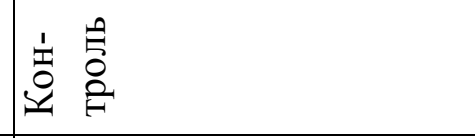 & 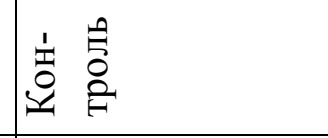 & 章言 \\
\hline ナ & 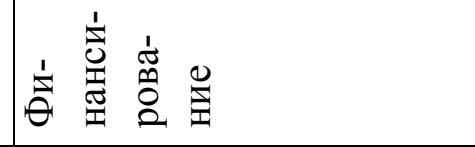 & 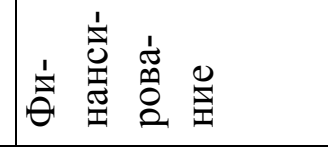 & 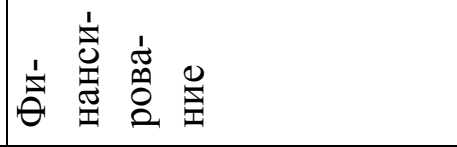 \\
\hline$m$ & 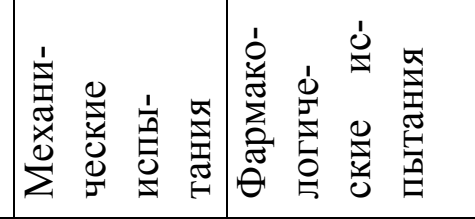 & 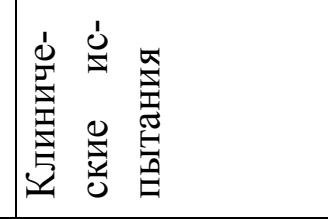 & 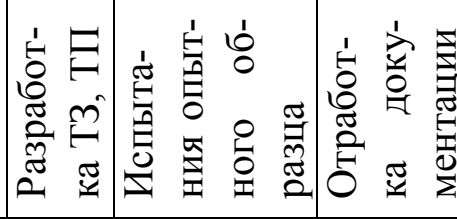 \\
\hline & 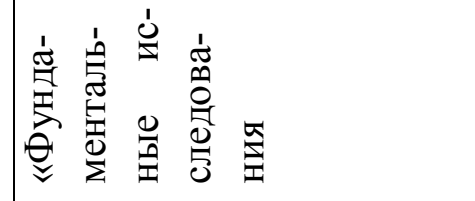 & 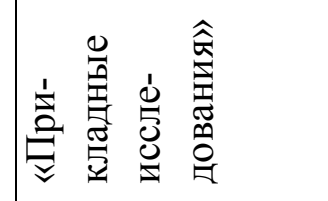 & 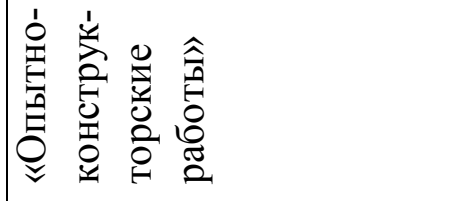 \\
\hline- & $N$ & $m$ & $\nabla$ \\
\hline
\end{tabular}




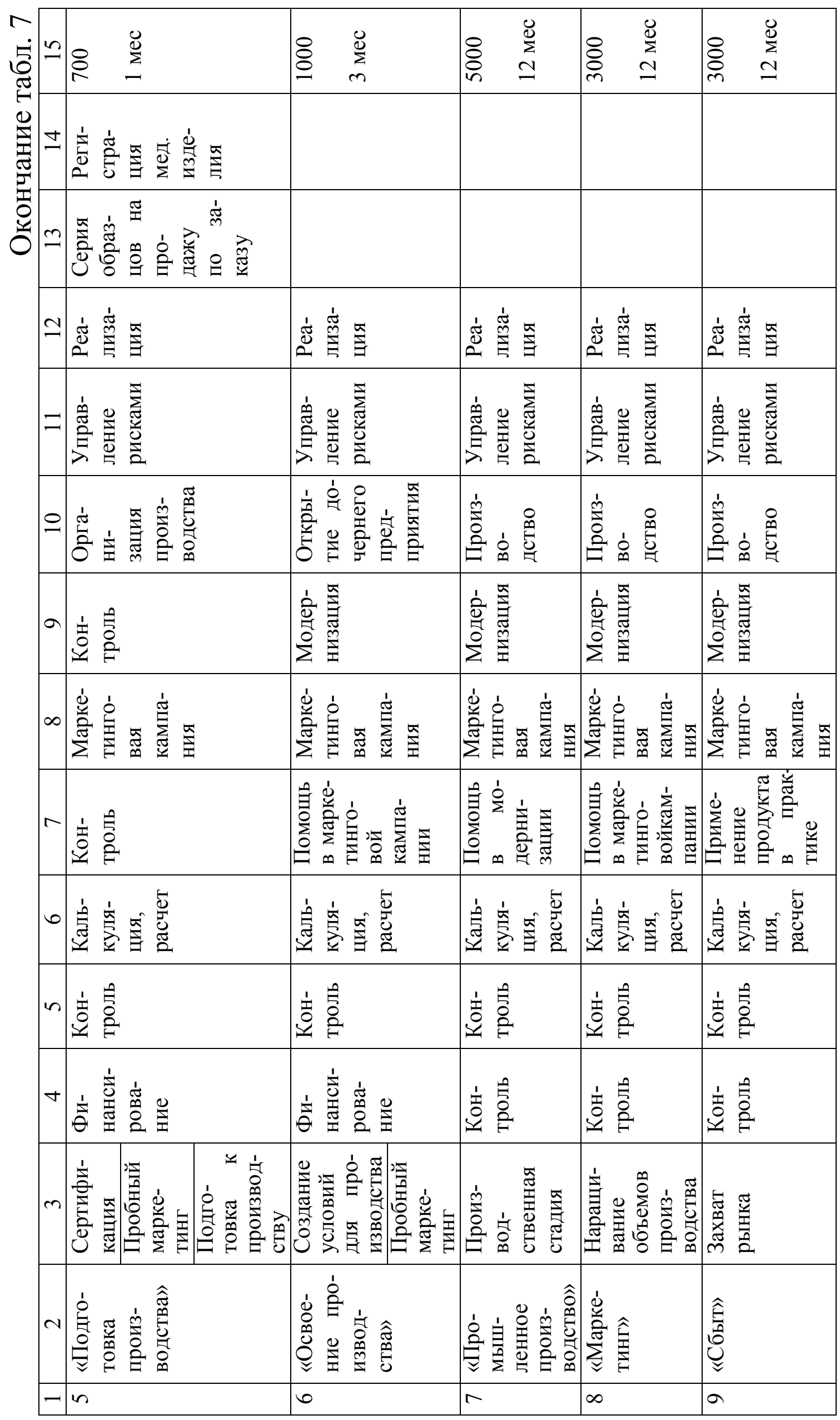


Показатели эффективности инвестиций

\begin{tabular}{|l|c|}
\hline Название показателя & Значение \\
\hline Дисконтированный период окупаемости (DPB), лет & 1,9 \\
\hline $\begin{array}{l}\text { Чистый приведенный доход (NPV) за 6 лет (ставка дискон- } \\
\text { тирования 10\%), млн руб. }\end{array}$ & 22,35 \\
\hline Индекс прибыльности (PI) & 2,54 \\
\hline Внутренняя норма рентабельности (IRR), \% & 52 \\
\hline
\end{tabular}

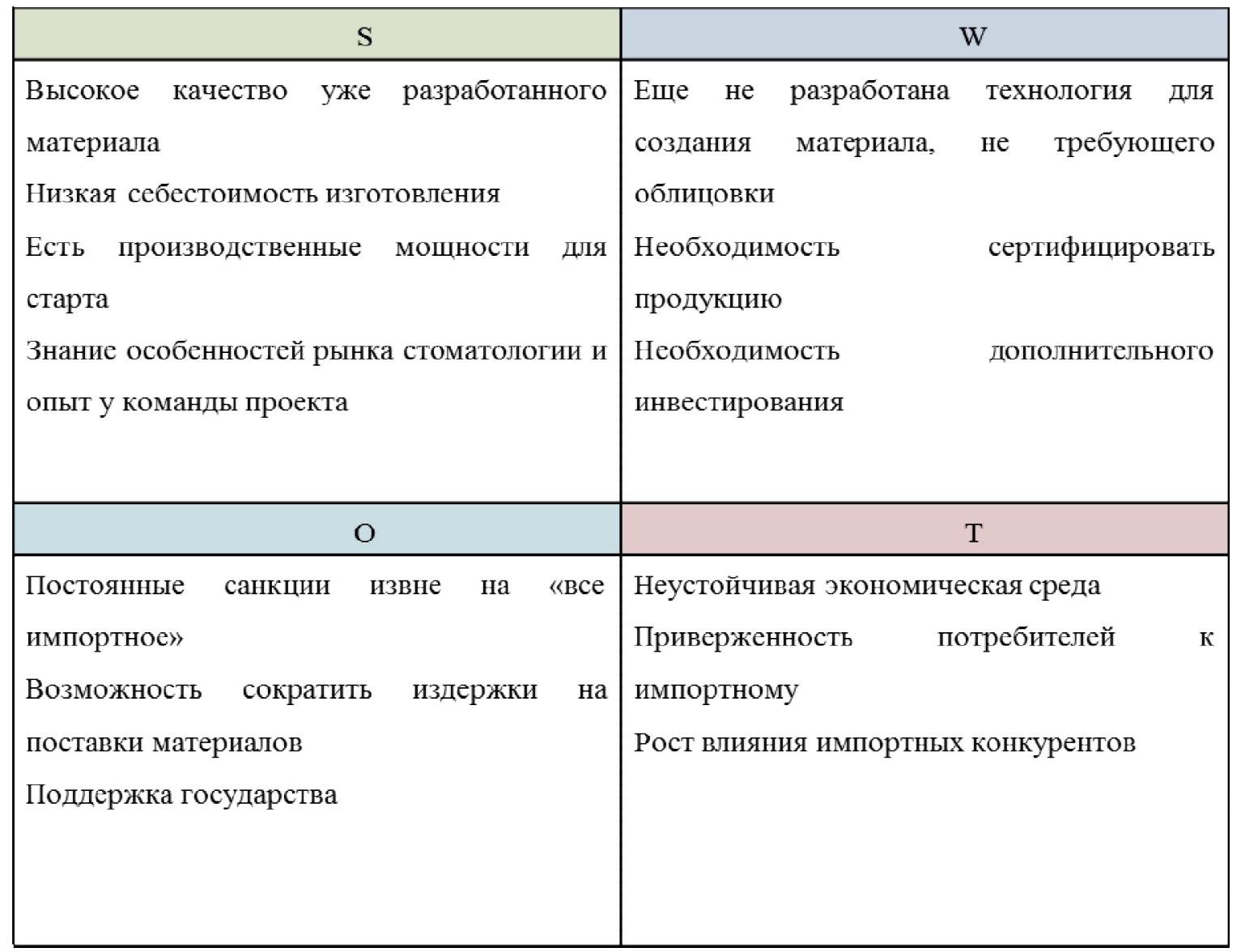

Рис. 19. SWOT-анализ проекта по внедрению плазмокерамики

Сравним каждое поле из SWOT-анализа по данному проекту. Для этого используем построение вариантов действий, основанных на пересечении полей. Рассмотрим различные сочетания факторов внешней среды и внутренних свойств компании. Рассмотрим все возможные парные комбинации и выделим те, что должны быть учтены при разработке стратегии в табл. 9. 


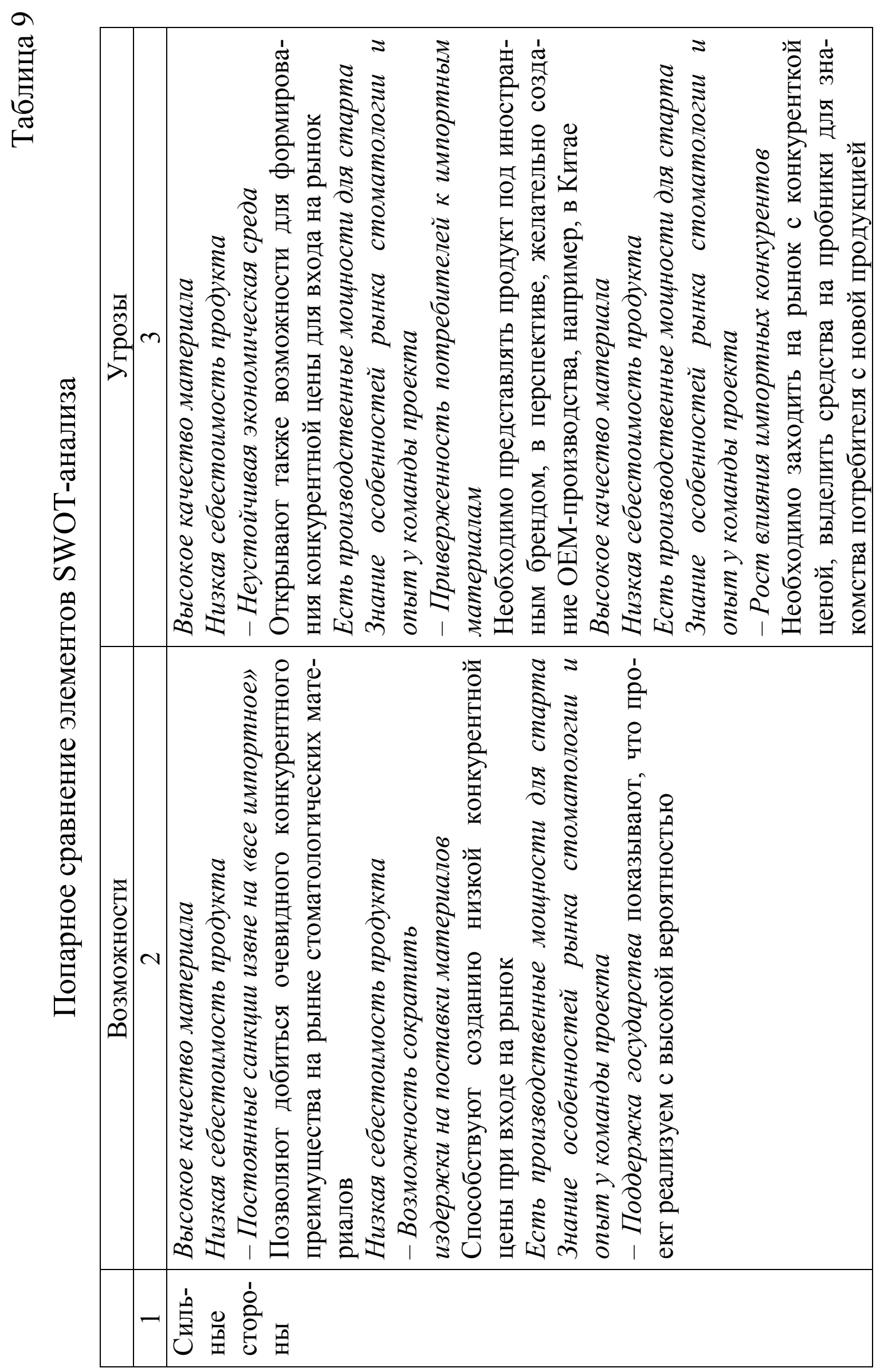




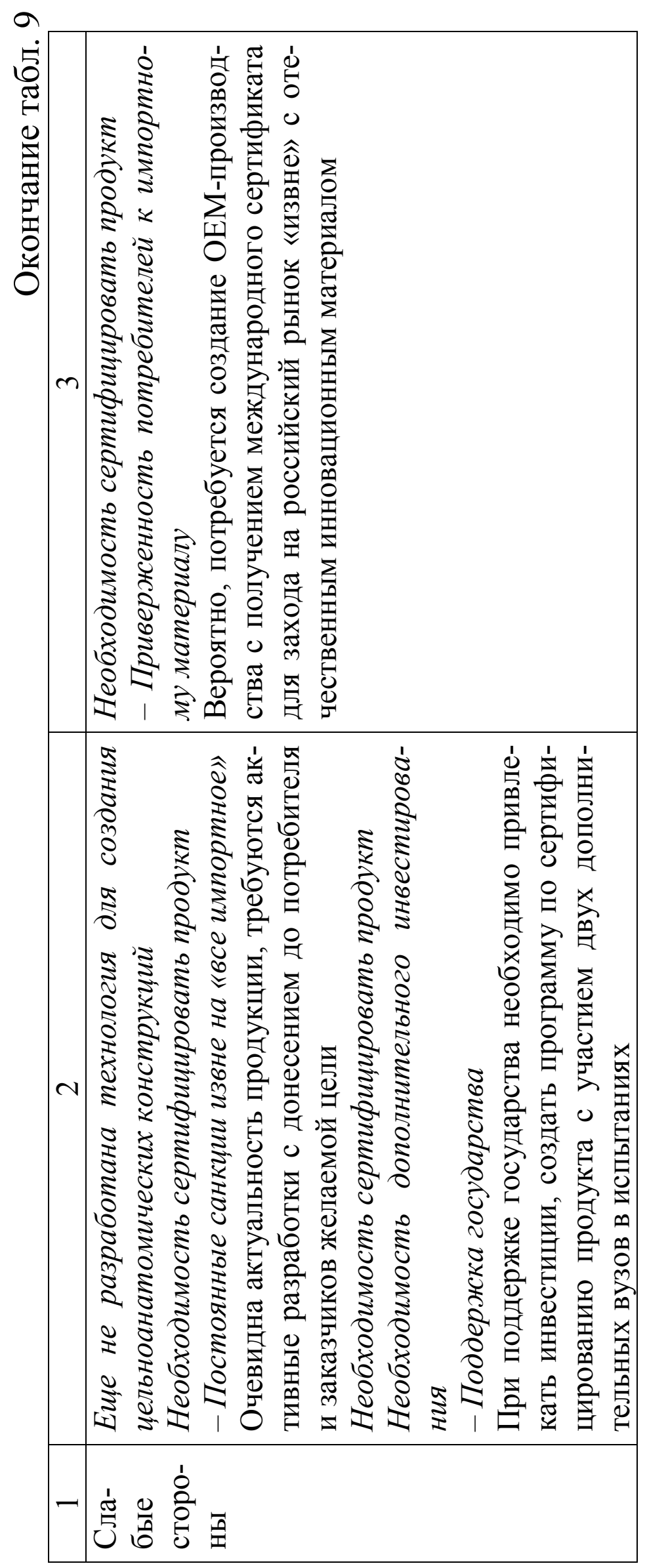


Таким образом, из приведенного SWOT-анализа очевидны высокие коммерческие риски и сравнительно низкие производственные и организационные риски по данному проекту.

Возможности, построенные на сильных сторонах:

- постоянные санкции извне на «все импортное»;

- возможность сократить издержки на поставки материалов;

- поддержка государства.

Сильные стороны, которые могут быть снижены возможностью угроз:

- высокое качество материала;

- низкая себестоимость продукта;

- есть производственные мощности для старта;

- знание особенностей рынка стоматологии и опыт у команды проекта.

Слабости, которые не позволяют использовать возможности, отсутствуют.

Слабости, которые делают компанию уязвимой для угроз:

- необходимость дополнительного инвестирования;

- еще не разработана технология для создания материала, не требующего последующей облицовки.

Преимущественным методом реагирования на риски по результатам их качественного анализа в рамках данного проекта является метод принятия рисков. Выделен бюджет, как единоразовые вложения в начале реализации проекта, так и ежемесячный.

При провале этапа НИОКР при создании материала, не требующего облицовки, имеются возможности для переключения на изготовление и продажу материала, требующего облицовочного слоя. 
Проблема сертификации материалов решается преимущественно на финансовом уровне. Уже имеются почти все необходимые результаты по испытаниям.

Дополнительные инвестиции по данному проекту подкреплены банковским кредитом и безвозмездным грантом.

Среди рисков, нуждающихся в наблюдении, выделены следующие:

1. Риск некомпетентности персонала.

2. Риск выхода из строя оборудования. Данный риск маловероятен, однако может иметь серьезные последствия при выведении нового продукта на рынок.

Следующим этапом риск-менеджмента для проекта плазмокерамики является количественный анализ рисков. Проведенный анализ показывает, что при повышении ставки дисконта до $30 \%$ с учетом того, что рассматриваемый проект должен быть отнесен к категории проектов с высокой степенью риска, экономическая целесообразность его реализация сохраняется.

При указанной ставке дисконтирования в $30 \%$, с корректировкой в сторону увеличения первоначальных вложений на $20 \%$ с учетом рисковых затрат, период окупаемости увеличивается проекта увеличивается в 2 раза, внутренняя норма доходности снижается до $29 \%$, NPV проекта сокращается почти в 2 раза, тем не менее проект остается эффективным.

Механизмы создания малого инновационного предприятия должны быть дополнены механизмами его эффективного функционирования.

Основой бизнес-процессов функционирования такого предприятия может стать концепция Total quality management (Всеобщее управление качеством - TQM). 


\section{ГЛАВА 4. КОНЦЕПЦИЯ TOTAL QUALITY MANAGEMENT (TQM) КАК ОСНОВА ЭФФЕКТИВНОЙ СИСТЕМЫ УПРАВЛЕНИЯ БИЗНЕС-ПРОЦЕССАМИ МАЛОГО ИННОВАЦИОННОГО ПРЕДПРИЯТИЯ}

\section{1. Понятие качества. Природа качества}

Понятие «качество» в различных источниках обладает различными трактовками. Важный элемент понимания определения состоит в механизме познания и происхождения. Познание идет постепенно, формируя представление о качестве, проникая все глубже в его сущность, создавая в сознании человека все более полное представление о предмете и явлении и находя словесное выражение познанным аспектам. Затем познание идет от качества к количеству, к их единству. В.И. Ленин так описал этот процесс: «Сначала мелькают впечатления, затем выделяется нечто - потом развиваются понятия качества (определение вещи или явления) и количества... Самым первичным и самым первоначальным является ощущение, а в нем неизбежно и качество...» [50, с. 83]. Словарь русского языка дает следующее определение:

- качество - существенный признак, свойство, отличающее один предмет от другого [51, с. 497];

- качество - степень достоинства, ценности, пригодности вещи, действия, соответствия тому, какими они должны быть [52, с. 787].

Из этого определения следует, что предметы, как и люди, обладают различными характеристиками, которые отличают объекты друг от друга. Такое определение в сжатой форме раскрывает многосторонность понятия «качество».

Советский энциклопедический словарь трактует данное определение следующим образом: «Качество - философская категория, выражающая осуществленную определенность объекта, благодаря 
которой он является именно этим, а не иным. Качество - объективная и всеобщая характеристика объектов, обнаруживающаяся в совокупности их свойств» [53, с. 865].

Слово «качество» отражено в словаре терминов по управлению качеством ИСО 9000. Многими выдающимися людьми написаны разнообразные статьи об этом предмете и имеется целый набор фраз, использованных для описания концепции качества. Приведем некоторые определения:

- ГОСТ 15467-79: «качество продукции - совокупность свойств, обусловливающих ее пригодность удовлетворять определенные потребности в соответствии с ее назначением» [54];

- стандарт ИСО 9000-2001: «качество - совокупность характеристик объекта, относящихся к его способности удовлетворить установленные и предполагаемые потребности» [55];

- Дж. Джуран: «качество - пригодность для определенной цели и использования»; (данное понятие включает в себя четыре элемента: восприятие потребителями проекта (дизайна) товара; степень, с которой товар соответствует проекту/спецификациям; доступность товара для приобретения, его надежность и ремонтопригодность; доступный сервис) [56, с. 125];

- Э. Деминг: «качество нацелено на требования потребителя, настоящие и будущие» [6, с. 56]

- американский специалист по качеству А. Фейгенбаум: «качество есть обобщенные комплексные характеристики рыночного исследования, проектирования, производства и обслуживания, в результате которых определяется степень соответствия произведенной продукции или услуги ожиданиям потребителя» [57, с. 78];

- еще одно определение А. Фейгенбаума: «качество - решение потребителя, а не инженера или маркетолога. Качество основано на взаимодействии потребителя с товаром, и измеряется в соответствии 
с удовлетворением его требований. Требования могут быть выражены явно или неявно, могут быть сознательными или неосознаваемыми, объективными или субъективными. Представления о качестве постоянно меняется, не стоит на месте на конкурентном рынке» [58];

- американский экономист Ф. Кросби: «качество - согласованность с требованиями» [59, с. 25];

- Дж. Харрингтон: «качество - удовлетворение ожиданий потребителей за цену, которую он может себе позволить, когда у него возникает потребность» $[60$, с. 53$]$;

- ИСО 9000:2005: «качество - это степень, с которой совокупность собственных характеристик выполняет требования». Требование - это потребность или ожидание, которое установлено, обычно предполагается или является обязательным.

Анализ понятия «качество» показывает, что оно далеко не однозначно. Люди, имеющие непосредственное отношение к созданию и использованию продукции, в слово «качество» вкладывают разный смысл. Ответ на этот вопрос не так прост, т. к. люди разных профессий, должностей, возраста имеют различные взгляды на эту категорию. Сравним ответы людей с собственным представлением о качестве:

- конструктор и разработчик изделия: качество - это соответствие продукции ее функциональному назначению, ее надежность, прочность и долговечность, обеспеченные на том уровне, какой был установлен в задании на разработку изделия;

- руководитель предприятия: качество - это требование рынка, заказчика и нормативной документации, конкурентоспособность. Проблемы с качеством - подводят поставщики, настигают конкуренты, требования стандарта слишком высоки; 
- работники ОТК: качество - это точное соответствие свойств продукции параметрам, указанным в чертежах, стандартах, в технологической документации;

- потребитель: качество продукции - это ее пригодность удовлетворить какие-либо его потребности, это удобство пользования, экономичность и красота форм, и все это по приемлемой цене.

Все многообразие существующих современных трактовок категории «качество» можно объединить в пять групп:

- качество как абсолютная оценка. В этом распространенном значении качество - синоним превосходства. В 1931 г. У. Шухарт определял качество как добротность, совершенство товара: «Качество товара представляет собой абсолютный, признаваемый всеми признак бескомпромиссного соответствия стандартам» [61, с. 15]. Согласно этому подходу качество нельзя измерить - оно является принадлежностью товара. Однако совершенство - категория абстрактная и субъективная, его восприятие людьми может значительно различаться. Поэтому это определение качества не может быть положено в основу оценки или измерения свойств продукции или услуг;

- качество как свойство продукции. В этом значении качество «служит производной от какого-либо измеримого количественного параметра продукта. Чем больше параметр, тем выше качество» [62, с. 78]. Однако подобное определение слишком узкое, так как оно не отражает полезность продукции для потребителя;

- качество как соответствие назначению. Согласно данной трактовке качество представляет собой способность продукта или услуги выполнять свои функции. Американский ученый Дж. Джуран определял качество изделия или услуги как «пригодность для использования»; 
- качество как соответствие стоимости. В этом случае качество определяется как соотношение полезности и цены продукта. Дж. Харринггон определял качество как «удовлетворение ожиданий потребителя за цену, которую он себе может позволить, когда у него возникает потребность» $[63$, с. 25]. С этой точки зрения качественным является продукт, который по своим полезным свойствам соответствует продуктам конкурентов, но продается дешевле либо превосходит по своим характеристикам аналогичные товары при равной цене. Такой подход ставит перед производителями цель поиска баланса между совершенствованием потребительских свойств продукции и снижением издержек по ее производству и реализации;

- качество как соответствие стандартам. В рамках данного производственного подхода качество определяется как «соответствие техническим стандартам и условиям, включающим целевые и допустимые значения тех или иных параметров продукции или услуг». Например, точным прибытием самолета будет считаться прибытие в пределах 15 минут от времени, установленного в расписании, т. е. целевым значением является время, установленное в расписании, а допустимым - 15 минут в ту или иную сторону. В то же время технические стандарты и условия бессмысленны, если они не соответствуют требованиям потребителей. Таким образом, справедливость и возможности практического применения каждого из перечисленных определений ограничиваются субъективностью восприятия свойств и полезности вещи каждым отдельным индивидом [64].

Э. Деминг на вопрос, что такое качество, отвечал: «Качество можно определить, только пользуясь системой оценок того человека, который пользуется товаром, кто судит о качестве» [6, с. 63].

Ведущие зарубежные ученые, занимающиеся проблемами управления качеством, дают следующие определения категории «качество». У. Шухарт понимал под качеством «различие между пред- 
метами, а также дифференциацию по признаку «хороший - плохой» $[65$, c. 32].

К. Исикава рассматривает два аспекта качества:

- объективные физические характеристики;

- субъективную сторону - насколько вещь «хороша».

Дж. Джуран в понятии качества выделяет:

- пригодность для использования (соответственно назначению);

- субъективную сторону: качество есть степень удовлетворения потребителя (для реализации качества производитель должен узнать требования потребителя и сделать свою продукцию такой, чтобы она удовлетворяла этим требованиям) [66, с. 24].

Российские ученые и специалисты, занимающиеся проблемой качества в различных ее аспектах, также многократно обращались и продолжают обращаться к трактовке понятия «качество» применительно к различным объектам исследования. «Качества вообще не бывает, а бывает оно только применительно к конкретным требованиям конкретных потребителей и оказывается, как правило, неким компромиссом между качеством и ценой», - утверждает Ф. Татарский. Ряд авторов подчеркивают объективность понятия «качество». Так, Э. Вейцман, полемизируя с Ф. Татарским, предлагает методику количественной оценки качества, с помощью которой можно сравнить, например, качество авторучки и трактора. Он отмечает, что «качество потребительской стоимости - это своего рода уровень научно-технической гармонии, в ней заключенной».

Таким образом, большинство ученых связывают понятие «качество» с удовлетворением определенных ожиданий и запросов потребителей в отношении того или иного товара или услуги.

Прежде чем рассматривать системы управления качеством, целесообразно предварительно обратиться к прошлому: проанализиро- 
вать причины зарождения и трансформации первых систем, выявить тенденции и закономерности их развития, определить наиболее значимые факторы, влияющие на их эффективность, не принимать за новое хорошо забытое старое, научиться чтить первопроходцев и т.д.

На рис. 20 показаны взаимоотношения общего менеджмента и менеджмента качества на протяжении временных этапов их развития. Принятые сокращения:

- management by quality (далее - MBQ) - менеджмент на основе качества;

- management by objectives (далее - MBO) - управление по целям;

- universal quality management (далее - UQM) - универсальный менеджмент качества;

- quality management (далее - QM) - менеджмент качества;

- total quality control (далее - TQC) - всеобщее управление качеством;

- company wide quality control (далеe - CWQC) - контроль качества в масштабе всей компании;

- quality circles (далее - QC) - кружки контроля качества;

- zero defects (далее - ZD) - система «ноль дефектов»;

- quality function deployment (далее - QFD) - развертывание функции качества;

- statistical quality control (далее - SQC) - статистический контроль качества.

Как видно из рисунка, основой общего менеджмента и менеджмента качества является система Ф. У. Тейлора, который создал концепцию научного менеджмента. В дальнейшем (с 20-х по 80-е годы) на длительный период развитие общего менеджмента и ме- 
неджмента качества осуществлялось по разным направлениям. «Главная проблема качества воспринималась и разрабатывалась специалистами преимущественно как инженерно-техническая проблема контроля и правления вариабельностью продукции и процессов производства, а проблема менеджмента - как проблема в основном организационного и даже социально- психологического характера».

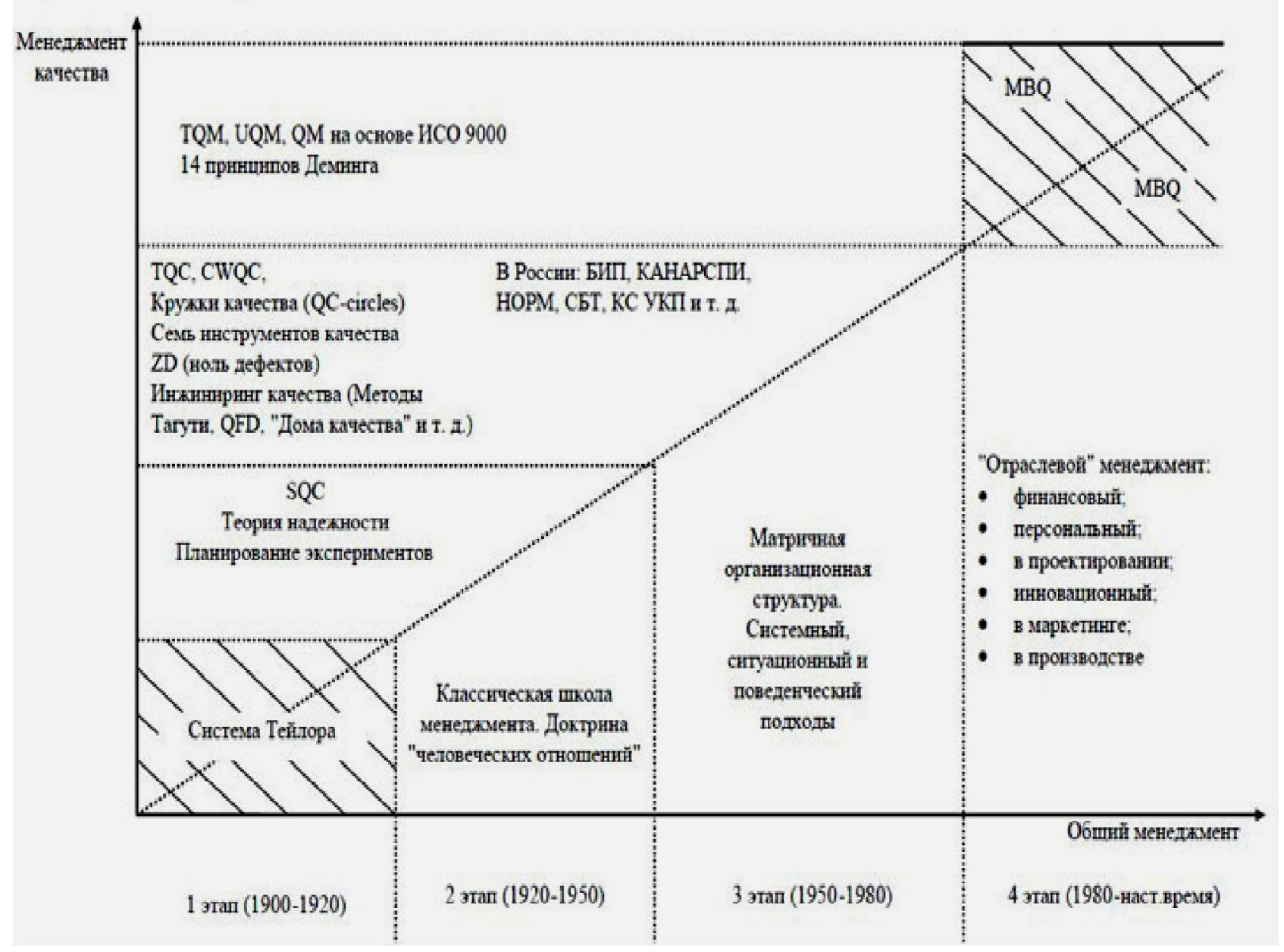

Рис. 20. Взаимоотношения общего менеджмента и менеджмента качества [67, с. 98]

Согласно научным трудам Уолтера Шухарта, структура проблемы вариабельности имеет еще две части, располагающиеся в невидимом для менеджера поле. «Теория вариабельности позволяет сделать эти две части видимыми для менеджера. Есть возможность увидеть следующую часть, применяя статистические методы для 
анализа деятельности. Методы, позволяющие обнаружить вариабельность процесса, определить, какие (общие или специальные) причины вариаций присутствуют в деятельности и какое реально существующее положение дел в деятельности организации». А далее надо обязательно определить корневые причины проблемы, потому что, только зная их, менеджер способен принять правильное решение. Основная цель деятельности по решению проблем на основе теории вариабельности следующая: какими бы причинами (общими или специальными) ни были вызваны проблемы, необходимо сделать так, чтобы по данной причине ни одна проблема в деятельности больше никогда не проявлялась.

Уолтер Шухарт перенес акцент с допускового подхода к управлению качеством на подход, направленный на обеспечение стабильности процессов и уменьшение их вариабельности. Это была истинно революционная идея, и понадобилось полвека, чтобы она завоевала свои позиции в промышленности.

\section{2. Система всеобщего управления качеством}

Всеобщее Управление Качеством (Total Quality Management, TQM) - современная интегрированная концепция качества, рассматривающая качество как результат операций, которые осуществляются на протяжении всего производственного цикла, имеющих отношение к функционированию технологического процесса, экономической и социальной сфере. В мировой практике понятие концепции TQM имеет широкое распространение, причем концепция затрагивает все области деятельности предприятия, то есть относится не только к производимым товарам и услугам, а ко всем основным аспектам менеджмента компаний.

TQM - это принципиально новый подход к управлению организацией любой отрасли, который нацелен на качество функциони- 
рования бизнес-процессов и соответствующие характеристики выпускаемых товаров, основанный на участии всех членов компании (персонала во всех подразделениях и на всех уровнях организационной структуры) и направленный на достижение долгосрочного успеха через удовлетворение требований потребителя и выгоды как для представителей организации, так и общества в целом .

В большинстве случае возникает подмена понятий по отношению к терминам контроля качества (quality control), управления качеством (quality management), обеспечения качества (quality assurance) и всеобщее управление качеством (total quality management). Контроль качества относится к средствам оперативного характера для выполнения системных требований, в то время как обеспечение качества направлено на достижение уверенности в выполнении установленных требований как внутри организации, так и по отношению к потребителю. Общее управление качеством включает контроль качества и обеспечение качества, а также такие дополнительные понятия, как политика в области качества, планирования и улучшения качества. Общее управление качеством осуществляется с помощью сформированной системы качества. «Всеобщее Управление Качеством вносит в данные понятия долговременную стратегию глобального руководства и участия всех членов организации в интересах самой компании, ее представителей, потребителей и общества в целом» [57].

Концепция TQM затрагивает основные, управляющие и вспомогательные бизнес-процессы предприятий. Эффективные результаты применения концепции TQM были достигнуты благодаря полному вовлечению персонала, системному функционированию основных подходов для достижения превосходного качества и удовлетворения потребителя. Изучение запросов потребителя - начало и конец цикла, включающего бизнес-планирование, организацию производства, подбор и мотивацию персонала, и другие аспекты. 
«Всеобщее управление качеством - это целенаправленный и структурно скоординированный подход к применению систем и методов управления качеством во всех сферах деятельности - от исследований и разработок до послепродажного обслуживания при участии руководства и служащих всех уровней менеджмента, а также при рациональном использовании технических возможностей предприятия» [57].

Еще одно определение TQM, указанное в международном стандарте ИСО 9000-2015 «Системы менеджмента качества. Основные положения и словарь»: «ТQМ (всеобщее руководство качеством) - подход к руководству организацией, нацеленный на качество, основанный на участии всех ее членов и направленный на достижение долгосрочного успеха путем удовлетворения потребителя и выгоды для всех членов организации и общества». Интересны примечания к понятию TQM из упомянутого стандарта:

- «все члены организации» означает персонал всех подразделений и всех уровней организационной структуры;

- сильное и настойчивое лидерство - руководство высшего административного менеджмента, обучение и подготовка всех членов организации, являющиеся существенными моментами для успешной реализации TQM;

- при использовании концепции всеобщего управления качеством (TQM) главная цель - достижение всех целей компании;

- концепция «выгоды для общества» подразумевает выполнение требований общества в целом.

Слово «total» имеет смысл - всеобъемлющий, тотальный, всеобщий. Все принципы, составляющие сущность ТQM, рассмотрены на рис. 21. 


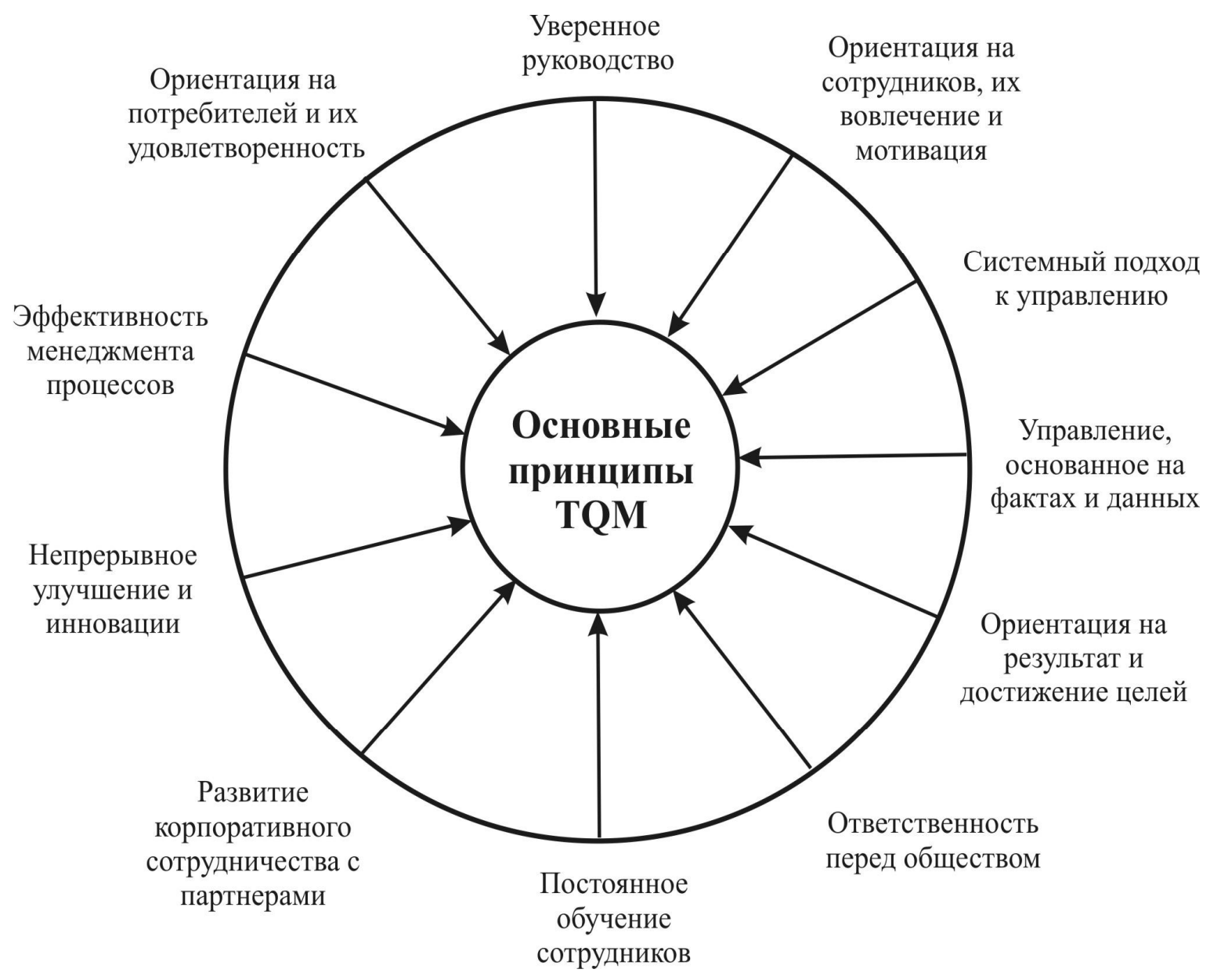

Рис. 21. Основные принципы TQM [58]

Первый аспект всеобщности, вкладываемый в слово «total», это вовлеченность высшего руководства в менеджмент качества.

Впервые Ф. Тейлор предложил данное разделение функций управления: «Необходимо разделить все функции управления на составляющие и каждому менеджеру поручить ответственность за реализацию определенной функции». На российских предприятиях данная методика применяется в настоящее время. Джозеф Джуран определил главные следствия подобного разделения:

- спад авторитета мастерства;

- огромный рост производительности;

- размывание ответственности за управление качеством между большим количеством структурных единиц; 
- дистанцирование высшего руководства от работ по управлению качеством.

Длительное время для большинства фирм главной целью являлось получение больших объёмов прибыли в очень короткие сроки (до сих пор для российских фирм это является главная и единственная цель). Такое стремление может достигаться любыми средствами. Однако применение концепции TQM изменило данный подход и доказало, что наиболее важной является иная цель - удовлетворенность потребителей. При соответствующем отношении долгосрочное существование компании на рынке, ориентация на того, кто финансирует ее деятельность, становится главным преимуществом, то есть на потребителя, а, следовательно, и на качество выпускаемой продукции. «Качество - сложная категория, которая определяется многими характеристиками, и требуется определённая техника управления, основанная на системном подходе. Во главе такой системы качества должен быть руководитель компании, который, в свою очередь, должен распространить функцию качества сначала на весь руководящий менеджмент, а затем и на всех работников организации» [59].

Второй аспект слова «total» - это охват всех процессов при управлении качеством. Переход на процессный подход позволяет устранить большинство негативных последствий функционального подхода. Всеобщее управление качеством основывается на теории вариабельности У. Шухарта и цикле непрерывных улучшений PDCA Э. Деминга, которые предполагают в своей основе непрерывное управление качеством процессов. Любая деятельность может рассматриваться как процесс: исследование рынка, проектирование продукции (услуги), производство, и т. д. «Процесс можно описать, измерять его результативность и эффективность, управлять, разрешая проблемы в деятельности, тем самым постоянно улучшая его результаты» [68, с. 96]. 
Третий аспект в слове «total»- включение в сферу внимания системы управления качеством потребителей и их требований. Долгое время под определением «качество» понимали продукцию, соответствующую установленным требованиям. Эти требования обычно не отражали ключевых, а тем более скрытых потребностей клиента. В настоящее время благополучием фирмы управляет удовлетворенность потребителей. Менеджеры должны научиться понимать ценности клиентов организации и подчинять им полное управление фирмой. Руководство должно перенести фокус на источник денежных поступлений - потребителей. Каору Исикава упоминал: «Первый этап управления качеством - выявить запросы потребителей. Второй этап - узнать, что будут покупать потребители. Нельзя определить качество, не владея информацией о затратах. Необходимо предупредить возможные дефекты и претензии».

Четвертый аспект в слове «total»- интеграция в единую систему цепочки «поставщик - потребитель». В процессе эволюции производственных отношений было выведено, что любое сотрудничество строится по схеме «поставщик - потребитель», или «заказчик - изготовитель». Иными словами, персонал не просто выполняет свою работу на своем рабочем месте, а производит результат для следующего рабочего в цепочке, а в целом возникает результат работы предприятия - готовая продукция. При этом необходимо учитывать не только требования потребителей к изготовленной продукции, но и требования к результату работы каждого элемента в технологической цепочке. Данный подход определяет отношения в системе управления организации, предполагают сотрудничество ради реализации общей цели (высокого качества продукции), что проявляется в совместном решении проблем участниками процесса вместо попыток избежать наказания за выявленные проблемы.

Пятый аспект слова «total» - вовлеченность всего персонала в систему всеобщего менеджмента качества. Длительное время счи- 
талось, что человек - источник ошибок, поэтому выгоднее создавать автоматизированные заводы и технологии. Однако даже в автоматизированных производствах невозможно обойтись без влияния человека. Постепенно промышленники стали осознавать, что главной действующей фигурой в производственной среде должен быть человек, который готов взять на себя ответственность за выполнение порученной деятельности. Смысл слова “total" заключается в ориентации на персонал, как на главную ценность компании. Человек не является механической частью производства. Он обладает чувствами, разумом, способностями (врожденными и приобретенными), знаниями, психоэмоциональными характеристиками, поэтому способен управлять собой и своим отношением к трудовой деятельности. Следовательно, важен уровень мотивации работников к своему труду и к работе в данной организации. Известно, что удовлетворенный и неудовлетворенный работник будут совершенно по-разному относиться к своей работе и получать различный результат. В связи с этим необходимо создать такие условия работы в организации, при которых работник будет полностью удовлетворен. «Удовлетворенность персонала - главное условие работы в TQM, так как необходимо активное участие в достижении главной цели организации достижение высокого качества продукции и постоянное повышение удовлетворенности потребителя» [59]. Важно, чтобы каждый работник хотел участвовать в разрешении проблем организации и непрерывном совершенствовании ее процессов. А такое положение дел возможно лишь тогда, когда каждый сотрудник уверен в том, что за свой вклад в достижение цели получит адекватное вознаграждение (материальное или нематериальное). Обучение и мотивация персонала - наиболее выгодные формы инвестиций компании. Правильно мотивированный персонал должен работать как одна команда.

Признаки командной работы:

- руководитель является лидером; 
- нацеленность на общий результат;

- взаимозаменяемость;

- взаимодействие;

- взаимоподдержка;

- готовность выполнять любую работу за пределами должностных обязанностей;

- комфортный климат и дружеские отношения.

Вовлеченность в работу по качеству всего персонала фирмы реализуется в TQM сверху вниз через установление политики и целей в области качества и последовательное доведение до всех уровней менеджмента. Политика и цели подвержены обсуждению в каждом подразделении на всех уровнях компании, где вносятся предложения и замечания. Политика и цели компании утверждаются руководством с учетом мнения работников. Движение снизу-вверх осуществляется через кружки качества, в которые на добровольной основе вовлекаются сотрудники предприятия, которые получили возможность принимать участие в управлении качеством компании. Кружки качества неразрывно связаны с применением статистических методов. В последние годы появились разные формы вовлечения персонала в управление качеством: инженерно-технические службы качества, конференции по качеству, конкурсы качества. Самое важное в функционировании кружков качества - быть услышанным, это право каждого из сотрудников, нарушение которого разрушает работу кружков качества, и все начинания по вовлечению персонала.

Шестой аспект в слове «total» - сбор и использование существенной для управления качеством информации о происходящих в компании и в среде функционирования бизнес-процессов. Обязательным условием функционирования концепции ТQМ является научный подход и применение методов и статистических инструмен- 
тов управления качеством. Ориентация на сбор и анализ данных о состоянии системы и процессов является созданием мощной информационной структуры анализа качества.

Седьмой аспект слова «total» - учет интересов собственников и инвесторов. Процветание компании прежде всего зависит от удовлетворённости потребителей и их отношения к качеству предлагаемой продукции или предоставляемой услуги. Однако для развития компании необходимы инвесторы и акционеры, которые предоставляют оборотные средства. Именно они должны думать о том, как сделать компанию привлекательной для инвестиций, и как повысить стоимость акций. В российском опыте данные вопросы не подвергаются осознанию по настоящее время. В последней версии концепции TQM, предложенной в 1997 году в Японии, подчеркивается, что «королями» для компании являются стейкхолдеры, т. е. заинтересованные в деятельности компании группы, включая работников и руководителей, потребителей, акционеров, инвесторов, партнеров по бизнесу, поставщиков и общество в лице государственных и общественных учреждений. Большое значение отводится последней группе. Компания обязана ориентироваться на требования общества, то есть иметь превосходную репутацию, прозрачные отношения между обществом, потребителем и компанией. Социальная значимость организации также занимает одну из лидирующих позиций. Общественное мнение делает компанию привлекательной для инвесторов, покупающих акции компании, для потребителей, покупающих выпускаемую продукцию или услуги, для сотрудников, мотивированных гордиться своей принадлежностью к компании, а также для поставщиков и партнеров, считающих достойным взаимодействие с компанией-производителем.

Восьмой аспект в слове «total» - постоянное совершенствование бизнес-процессов. Система менеджмента компании нацелена на постоянное выявление отклонений в каждом процессе и непрерыв- 
ное разрешение этих проблем с целью постоянного улучшения своей деятельности, направленное на увеличение удовлетворенности потребителей и заинтересованных сторон.

Цель TQM: достижение долгосрочного успеха путем максимального удовлетворения запросов потребителей, сотрудников и общества.

Задачи TQM: постоянное улучшение качества посредством регулярного анализа результатов и корректировки деятельности, полное отсутствие дефектов и непроизводственных затрат, выполнение обязательств и организация бизнес-процессов точно в срок.

Тактика TQM: предупреждение причин дефектов; вовлечение всех сотрудников в деятельность по постоянному улучшению качества; эффективное стратегическое управление; непрерывное совершенствование качества продукции и бизнес-процессов; использование научных подходов при решении задач; постоянный анализ функционирования предприятия.

Методические средства TQM: средства для сбора данных; средства представления данных; методы статистической обработки данных; теория общего менеджмента; теория мотиваций и психология межличностных отношений; экономические расчеты, системный анализ производства, управление с помощью планирования. TQM технология руководства процессом повышения качества.

TQM состоит из трех частей $[69$, с. 89$]$ :

- коренная, ключевая система - это методы и средства, используемые для анализа и исследований, основанные на общепризнанном математическом аппарате, статистических методах контроля и используемых во всех компаниях. Они могут импортироваться в любую страну;

- система технического обеспечения - это приемы и программы, позволяющие обучить персонал правильному применению 
и взаимодействию персонала. Эта система отражает специфику страны и каждого предприятия, связана с национальной культурой и традициями страны. Создаётся самостоятельно на уровне организации компании;

- система непрерывного развития самих принципов и содержания TQM. Имеет определённую специфику, наиболее полно отражает национальные особенности, экономические порядки государства, действующее законодательство. Целью всеобеего управления качеством является достижение более высокого качества выпускаемой продукции.

Японская концепция предусматривает четыре уровня:

- соответствие стандарту;

- соответствие использованию;

- соответствие фактическим требованиям рынка;

- соответствие скрытым (предполагаемым) потребностям.

Эффективность всеобщего управления качеством зависит от трех ключевых условий:

- руководитель предприятия возглавляет работу по непрерывному совершенствованию качества;

- преобразование организационной структуры или создание специально под систему управления качеством;

- инвестиции вкладываются не в оборудование, а в людей.

\section{3. Инструменты управления качеством}

В настоящее время, управление качеством является управленческой деятельностью всех этапов жизненного цикла товаров и, в то же время, их взаимодействия с внешней средой. Сегодня по всему миру создаются и совершенствуются разнообразные модели управ- 
ления качеством, которых на данный момент уже можно насчитать сотни. Главной целью всех этих моделей является производство таких товаров, которые соответствовали бы всем требованиям потребителей.

Как уже было сказано, существует огромное множество методов и моделей в сфере управления качеством, способствующих проведению анализа существующего положения компании и выявлению ключевых проблем, что в дальнейшем помогает разработать конкретные шаги по увеличению качества товара и по снижению издержек при производстве продукции. Примерами таких методов могут быть: диаграмма Парето, схема Исикава, Диаграмма корреляции, цикл Деминга, контрольная карта Шухарта и другие. Важную роль анализа системы менеджмента качества на предприятии занимает метод построения производственных процессов - цикл Деминга Шухарта.

Будучи инженером, Уолтер Шухарт рассматривал свою концепцию применительно только к производственным процессам. Вместе с этим, его ученик, Эдвардс Деминг первым понял, что цикл управления качеством, основанный на теории вариабельности, может быть применен к процессам в любой деятельности. Цикл Деминга - Шухарта позволяет выявить причины брака, а благодаря непрерывности цикла, позволяет корректировать процесс устранения дефекта. Эдвардс Деминг развил концепцию непрерывного улучшения качества и ввел в повседневную практику менеджмента использование цикла PDCA. В системе Шухарта-Деминга цикл изменил свою сущность, его отдельные фазы - планирование, выполнение, проверка и действия - стали рассматриваться как элементы общей командной работы. На основе теории вариабельности У. Шухарта методическое обоснование концепции непрерывного совершенствования качества дал Э. Деминг в виде цикла PDCA (plan do - check - act), что в русском адаптированном переводе означает 
«планируй - выполняй - проверяй - корректируй», или PDSA (plan - do - study - act), что означает «планируй - выполняй - изучай - действуй».

Этапы цикла Шухарта-Деминга реализуются следующим образом:

- планируй - менеджер, в управлении которого находится процесс, планирует то, как, каким образом он будет осуществляться;

- делай - подчиненные менеджера, исполнители, выполняют процесс в строгом соответствии с тем, как запланирован процесс;

- проверяй - о результатах процесса его исполнители и менеджер собирают данные (показатели процесса), менеджер их анализирует и определяет: присутствуют общие или специальные причины вариаций, стабилен или нестабилен процесс, осуществляет поиск корневых причин проблем;

- действуй - менеджер предпринимает управленческие решения по улучшению процесса, основанные на фактах.

В отличие от механизма управления Ф. Тейлора, этапами цикла Шухарта-Деминга управляет один человек - менеджер. При помощи данного цикла осуществляется управление качеством процессов. Цикл Шухарта-Деминга применим для любого процесса. Интересную модернизацию этого цикла под названием «Современный цикл менеджмента качества» в работе предлагает В.Е. Швец, удлиняя цепочку РDCA до восьми звеньев:

- определи требования (на продукцию, процессы, процедуры);

- планируй;

- организуй (распредели ответственность, полномочия и определи взаимодействие;

- выполняй процесс;

- проверь и выяви соответствия или несоответствия; 
- анализируй несоответствия;

- выполняй корректирующие действия;

- используй мотивацию.

Статистические методы регулирования и контроля технологических процессов не только получили повсеместное распространение, но их роль в обеспечении качества процессов многократно выросла, а сами методы получили дальнейшее развитие.

Базируясь на правилах построения цикла, Эдвардс Деминг сформулировал также ряд «прагматических аксиом»:

- любая деятельность может рассматриваться, как технологический процесс и поэтому может быть улучшена, т. е. при управлении качеством любой деятельности и качеством результата этой деятельности необходим процессный подход;

- производство должно рассматриваться как система, находящаяся в стабильном или нестабильном состоянии. Это значит, что результат решения конкретных проблем диктуется состоянием системы, поэтому необходимы фундаментальные изменения, касающиеся самой системы;

- высшее руководство предприятия должно во всех случаях принимать на себя ответственность за его деятельность [70, с. 258].

Подводя итог предыдущим разделам, всеобщий контроль качества (TQM) - это система управления качеством, применяемая с целью улучшения бизнес-процессов на предприятии, а также улучшение качества выпускаемой продукции. Система базируется на множестве методов совершенствования и управления производственными процессами. Но как добиться желаемого результата - выработать стратегию развития предприятия с конкретными показателями работы? Наилучшим вариантом реализации намеченных планов будет являться применение инструмента Хосин-Канри. 
Хосин-Канри - это метод стратегического управления компанией, в процессе реализации которого устанавливаются направления деятельности предприятия, цели и применяемые для их достижения инструменты и способствующий вовлечению руководителей и персонала в выработку общего видения и общего плана действий. Хосин-Канри также рассматривается как «процесс развертывания стратегической политики или управление стратегической политикой предприятия» [71, с. 46].

Прежде всего, Хосин-Канри - это инструмент, связывающий макро- и микроуровни организации. «Хосин-Канри помогает увидеть самый верхний уровень целей компании, работая на микроуровне, и в тоже время понимать возможности, творческий потенциал и проблемы микроуровня, находясь на самых высоких уровнях управления» [72].

Важно отметить, что система Деминга-Шухарта PDCA неразрывно связана с применением инструментам стратегического управления Хосин-Канри. Хосин-Канри - процесс достаточно разнонаправленный. Он включает в себя реализацию циклов PDCA на разных уровнях менеджмента в оперативном, среднесрочном и долгосрочном масштабе.

Циклы PDCA в системе Хосин-Канри:

- долгосрочная стратегия. Общий план деятельности на длительный период (5-100 лет) - направлен на осуществление важнейших преобразований или внесение изменений в миссию организации;

- среднесрочная стратегия. Это почти законченный план действий, который включает в себя критерии улучшений существующих процессов и рассчитанный на среднесрочную перспективу (3-5 лет). Ориентирован на формирование необходимых характеристик;

- ежегодный план (тактика). Конкретный план действий на ближайший период (6-18 месяцев), который подразумевает форми- 
рование свойств и характеристик, способствующих повышению конкурентоспособности компании;

- оперативная деятельность. Достаточно конкретные проекты (3-6 месяцев) реализуемые с целью применения инноваций в стандартизированных процессах [71, с. 186].

Применение циклов в системе Хосин-Канри проводятся специально созданными для этого сетью рабочих групп, в состав которых входят высшее руководство, менеджеры среднего звена и в обязательном порядке весь рабочий персонал компании. Такие группы или команды создаются и объединяются по принципу иерархии, обязанности по планированию и внедрению распределяются между ними следующим образом:

- Хосин-команда - это управленческая команда самого высокого уровня, которая отвечает в целом за стратегическое планирование и процесс реализации политики;

- тактическая команда - разрабатывают и управляют проведением определенных тактик по формированию некоторых характеристик, улучшающих конкурентоспособность организации;

- оперативная команда - разрабатывает и осуществляет оперативные проекты по совершенствованию конкретных процессов;

- команда исполнителей - разрабатывает и руководит проведением периодических относительно крупных усовершенствований и осуществлением непрерывного улучшения.

Каждый цикл PDCA в системе Хосин-Канри имеет свою определенную задачу, зависимую от продолжительности и того, каким образом он связан с общими целями компании. В итоге, чем длиннее определенный цикл, тем выше степень ответственности в управленческой иерархии организации. В целом процесс Хосин-Канри не имеет конечной точки, и циклы стратегических преобразований повторяются с периодичностью 1-2 раза в год. «Процесс примене- 
ния циклов PDCA в системе Хосин-Канри, проводимый в контролируемых условиях стандартизированных рабочих процессов, позволяет вовлечь всех сотрудников компании для проверки правильности выбранной компанией стратегии» [72, с. 130].

Одним из основных условий реализации политики ХосинКанри является создание документа, в котором фиксируются результаты процесса разработки стратегии компании. Для этого в системе Хосин-Канри применяют такой инструмент, как «Х-матрица», которая дает возможность представить весь процесс разработки стратегии на одном листе бумаги. Важно, что этот документ выполняет функции итогового документа, в котором фиксируются принятые решения и обсуждаемые аргументы, необходимые для формулировки и претворения в жизнь эффективной стратегии.

«Х-матрица представляет собой пакет планов работы команд, которые описывают в практических, а также стратегических терминах основную суть бережливой организации: создать и укрепить конкурентоспособность, измеряемую в конкретных показателях, современных технологиях, высшем уровне качества, низких затратах и поставке «точно в срок». Каждый план работы команды, который включается в систему Х-матриц, призван решить конкретную задачу: ликвидировать непроизводительные потери и уменьшить нестабильность, которые мешают одержать победу над конкурентами. Х-матрица оформляется в формате А3, представленном на рис. 22, так как данный формат наиболее нагляден, лаконичен и мобилен, он является самым оптимальный форматом, для того чтобы ничего не упустить и в то же время избежать написания чего-либо лишнего.

Данная форма используется для разработки и применения среднесрочной стратегии и годового Хосин-плана компании, а также предназначена для объединения отдельных планов команд различных уровней в единый документ, направленный на реализацию стратегии. 


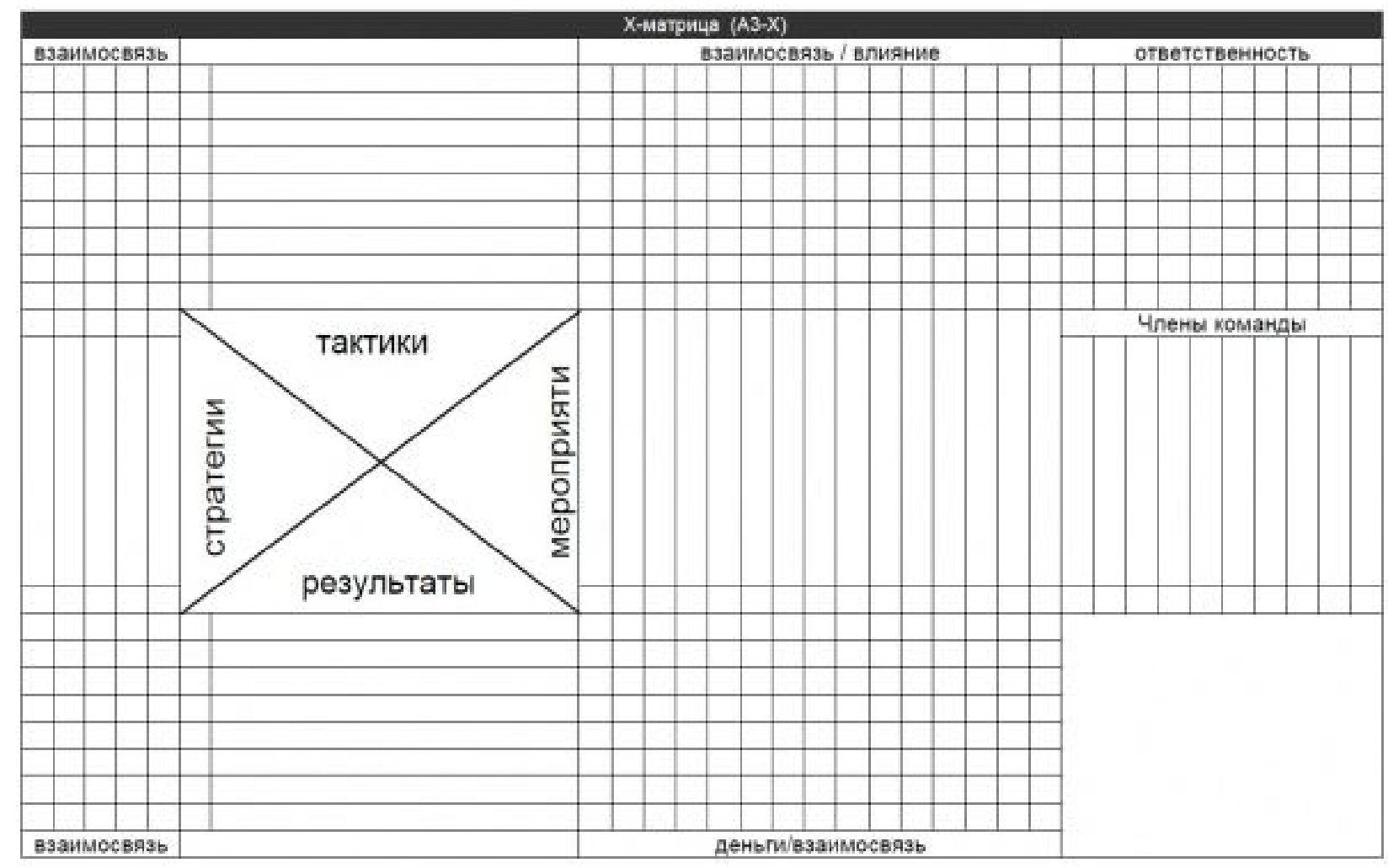

Рис. 22. Построение Х-матрицы

Х-матрица состоит из четырех основных блоков [44]:

- стратегии - это основной движущий фактор в матрице, описание того, что будет делаться, как на текущий период, так и в ближайшие 2-3 года;

- тактики - описание того, как будет достигаться выбранная стратегия в период ближайших 6-18 месяцев;

- процесс - критерии оценки, с помощью которых будет оцениваться ход развития всего процесса;

- результаты - описание всех результатов качественного управления процессом.

Дополнительные блоки матрицы:

- члены команды - перечисляются участники всех процессов;

- ответственность - отмечается, кто за какой процесс несет ответственность; 
- взаимосвязи - фиксируются имеющиеся взаимоотношения между процессами.

Перед тем как заполнять Х-матрицу, требуется выполнить стратегический анализ и определить пути развития организации. Только после этого заполняется первый блок матрицы, содержащий сформулированную стратегию. Следующим шагом выбираются и заносятся тактики, которые позволят обеспечить выполнение выбранной стратегии. Далее необходимо описать проекты, то есть, что необходимо выполнить, чтобы реализовать сформулированные тактики. Затем прописываются планируемые финансовые итоги, то есть то, для чего всё это делается. В дальнейшем определяются взаимосвязи между выбранными стратегией и тактиками. В итоге установление этих взаимосвязей позволяет понять, насколько тактики способны реализовать стратегии. Далее необходимо определить, с помощью, каких проектов можно реализовать выбранные тактики и сколько это будет стоить. Взаимосвязи также устанавливаются и между проектами и тактиками. Определение взаимосвязей позволит понять, какой проект способен выполнить ту или иную тактику, а также какая тактика сможет реализовать выбранную стратегию. В результате будет получено видение далекой цели и конкретных шагов, позволяющих ее достичь. На последнем этапе выбираются ответственные лица. И после этого в матрице проставляется связь между проектами и результатами (то есть позволяют ли эти проекты получить желаемые результаты) и устанавливается связь результатов со стратегиями.

«Х-матрица - это ключевой документ в системе Хосин-Канри, который призван обеспечить максимально четкую реализацию данного подхода. В результате внедрения этого метода менеджеры начинают обсуждать ход выполнения поставленных задач чаще и в непосредственном контакте со своими подчиненными, а также с вышестоящими руководителями» [72]. 
Подход Хосин-Канри позволяет сформировать планирование и организацию процессов улучшений на предприятии, то есть указывает направления развития и сроки достижения. В зависимости от установленных долгосрочных стратегических целей менеджмент организации сталкивается с нестабильными явлениями в области управления системой. Для понимания возникновения дефектов требуются специальные инструменты, которые позволяют выявить проблемы подразделений.

Еще одним эффективным инструментом управления качеством бизнес-процессов компании является Диаграмма Исикавы.

Диаграмма Исикавы - инструмент управления качеством, цель применения которого сводится к визуализированной взаимосвязи между возникающей проблемой, а также причинами её возникновения. Иное название данного инструмента - причинно-следственная диаграмма (диаграмма «рыбья кость»). Диаграмма способствует выявлению ключевых параметров процессов в зависимости от заданных факторов. Факторами возникновения несоответствий являются:

- методы работы (действий);

- механизмы производства;

- материал (входящее сырьё для производства);

- контроль производства изделий;

- окружающая среда (внешнее воздействие);

- человек.

С помощью диаграммы Исикавы можно выявить, какой информации не хватает для установления истинной причины возникновения отклонения, то есть уменьшить область принятия решения. Факторы, связанные с человеком включают состояние персонала при выполнении бизнес процессов, в частности физическое состояние и квалификацию. Причины, связанные с методом работы, заключа- 
ются в совершенстве технологических операций и процессов, механизмы описывают техническое состояние оборудования и периода профилактических работ. Факторы, связанные с материалом - это свойства обрабатываемых объектов, которые находятся на середине производственной цепочки, либо на уровне входного контроля. Факторы контроля - вероятность возникновения ошибок при реализации технологических операций. Причины, связанные с окружающей средой - это воздействие внешней среды на выполнение технологических операций, такие как влажность, освещённость станка. На рис. 23 изображена диаграмма Исикавы с описанием причин отклонений, которые находятся во взаимосвязи с факторами появления.

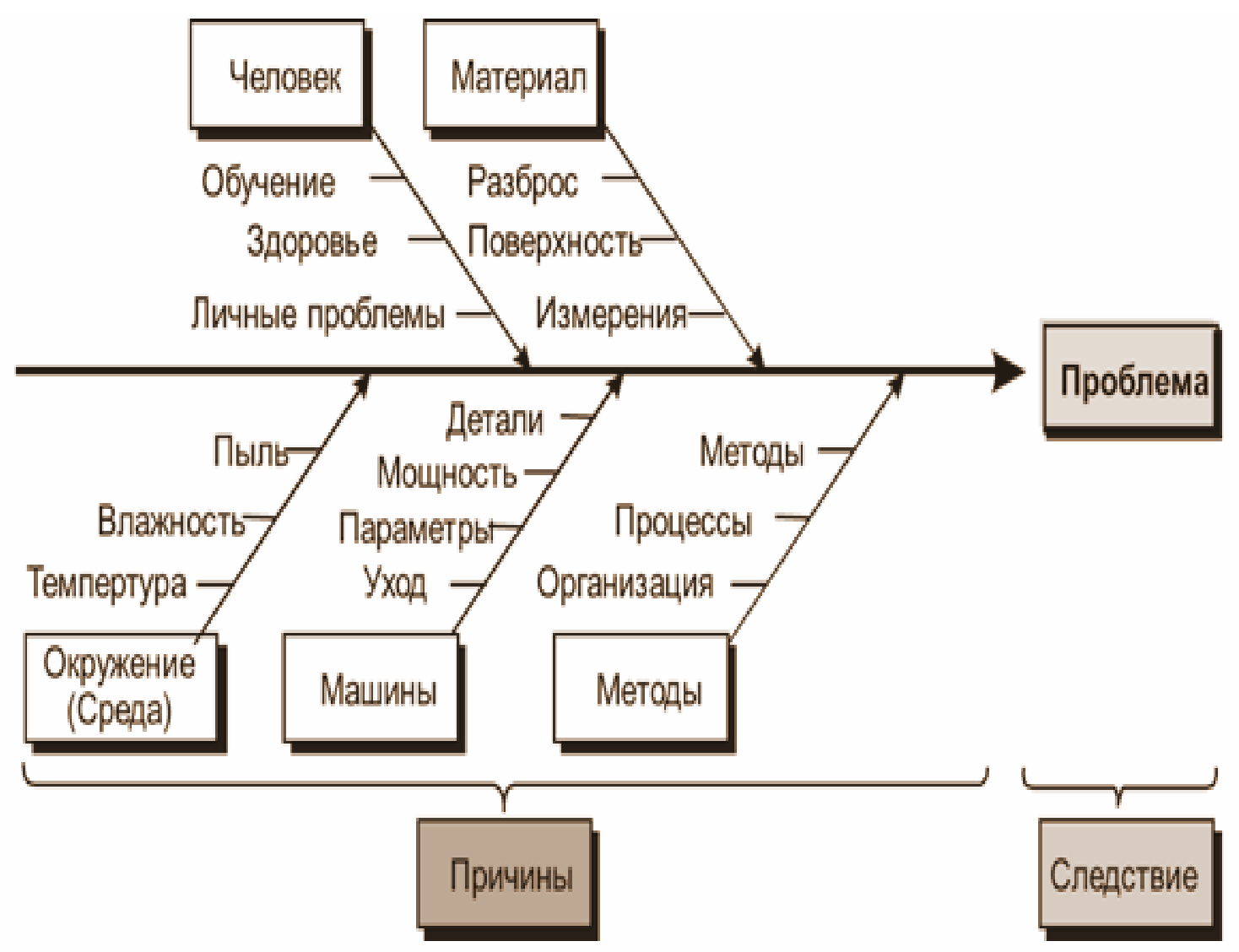

Рис. 23. Диаграмма Исикавы

Следующим инструментом управления качеством являются «Контрольные карты Шухарта». Это линейчатый график, построенный на основании собранных статистических данных в различные 
временные периоды. Данный инструмент отражает динамику бизнес-процесса, что позволяет достичь управляемости процесса.

Важным элементом контрольной карты будут являться линии, пересекающие график в некоторых областях. Линии отражают верхние и нижние контрольные пределы измеряемых величин, а также среднее значение. Выход графика за пределы контрольных границ обуславливает неуправляемость процесса, то есть статистическую нестабильность. На рис. 24 изображён пример построения контрольной карты Шухарта.

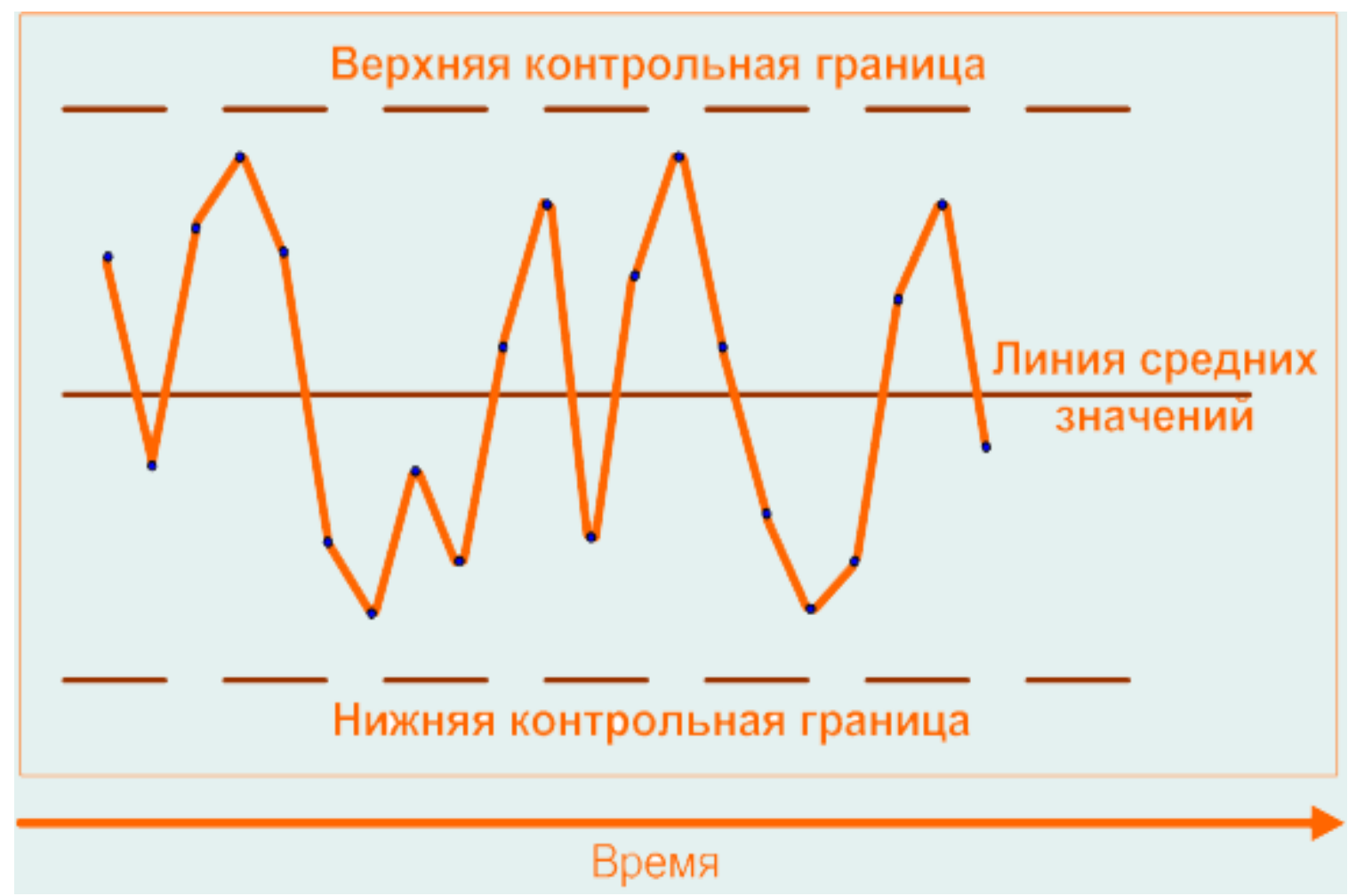

Рис. 24. Контрольная карта Шухарта

Существуют установленные правила формирования данного инструмента. Порядок сбора статистических данных, построения графика отражён в ГОСТ 50779.42-99 «Статистические методы. Контрольные карты Шухарта». Применение контрольных карт способствует отображению изменений показателей с течением времени, что позволяет видеть динамику процесса. В частности, если кон- 
трольная карта показывает периодические выходы показателей за границы контрольных пределов, следует прореагировать на данные изменения. При единичном выходе графика общая картина не меняется и процесс так и остаётся управляемым.

Проведем анализ представленных инструментов управления качеством, с выделением их преимуществ и недостатков. Результаты анализа представлены в табл. 10. Важно заметить, что для достижения лучшего результата данные инструменты должны работать в комплексе, что обеспечит синергетический эффект от их применения.

Анализ инструментов управления качеством

\begin{tabular}{|c|c|c|}
\hline Инструмент & Преимущества & Недостатки \\
\hline $\begin{array}{l}\text { Диаграмма } \\
\text { Исикавы }\end{array}$ & $\begin{array}{l}\text { - графическое отображение } \\
\text { взаимосвязи исследуемой про- } \\
\text { блемы и причин; } \\
\text { - возможность проведения ана- } \\
\text { лиза цепочки причин возникно- } \\
\text { вения дефектов }\end{array}$ & $\begin{array}{lr}-\quad \text { сложность } & \text { правильного } \\
\text { определения } & \text { взаимосвязи } \\
\text { исследуемой } & \text { проблемы } \\
\text { и причин } & \end{array}$ \\
\hline $\begin{array}{l}\text { Контрольные } \\
\text { карты Шу- } \\
\text { харта }\end{array}$ & $\begin{array}{l}\text { - визуальное определение пока- } \\
\text { зателей процесса; } \\
\text { - выявление различий между } \\
\text { случайными и системными на- } \\
\text { рушениями процесса }\end{array}$ & $\begin{array}{l}\text { - высокие требования к во- } \\
\text { влечению персонала; } \\
\text { - постоянная фиксация по- } \\
\text { казателей в реальном вре- } \\
\text { мени }\end{array}$ \\
\hline
\end{tabular}




\section{ГЛАВА 5. АНАЛИЗ ФУНКЦИОНИРОВАНИЯ СИСТЕМ УПРАВЛЕНИЯ КАЧЕСТВОМ. ОПЫТ ВНЕДРЕНИЯ. ПРИМЕНЯЕМЫЙ ИНСТРУМЕНТАРИЙ}

\section{1. Анализ мирового и российского опыта применения концепции TQM}

Всеобщее управление качеством (TQM) - это концепция управления предприятием, направленная на развитие качества выпускаемой продукции, а также совершенствование бизнес-процессов внутри организации, с целью удовлетворения конечного потребителя. Качество процессов - неотъемлемая часть эффективного функционирования организации, которая включает в себя ликвидацию производственных потерь, сбалансированную реализацию стратегических целей компании, мотивацию персонала.

В мировой практике каждое государство имеет определённую модель управления качеством. У первоначальных истоков TQM профессор Эдвардс Деминг, один из основателей теории всеобщего менеджмента качества, выделил 14 основных постулатов, описывающих эффективную систему развития качества в организации:

- сделать постоянной целью улучшение качества продукции и услуг;

- принять новую философию;

- прекратить зависимость от постоянного контроля как способа достижения качества;

- прекратить практику заключения контрактов с поставщиками на основе низкой цены;

- постоянно улучшать организационную систему предприятия;

- внедрить обучение на рабочих местах; 
- учредить руководство. Способствовать двусторонней связи между руководством и подчинёнными для повышения эффективности и производительности;

- искоренить страх надвигающихся перемен;

- устранить барьеры между подразделениями компании;

- избегать пустых лозунгов и призывов к совершенствованию качества на предприятии;

- исключить цифровые квоты для управления сдельной работой на предприятии;

- дать возможность гордиться «своим мастерством» и принадлежностью к компании;

- поощрять образование и самосовершенствование;

- вовлечь каждого сотрудника в работу по преобразованию компании и совершенствованию процессов на предприятии.

В Японии модель управления качеством приобрела государственный характер, её внедрение было выполнено за короткий срок и весьма успешно. Система затрагивала каждого члена организации, от рабочего персонала до высшего руководящего менеджмента. Управление качеством сводится к следующим подходам:

- выявить запросы потребителей;

- определить затраты, необходимые для достижения качества;

- создать условия по предупреждению возможных дефектов и рекламаций, а также установить корректирующие меры по исправлению недостатков;

- исключить необходимость тотального контроля.

Особенности японской модели управления качеством:

- полноценное участие всех структурных уровней менеджмента организации; 
- обучение кадров методам качества, «встраивание качества» в продукцию;

- создание «кружков качества» как орган устранения дефектов продукции и функционирования бизнес-процессов;

- применение статистических методов контроля качества выпускаемой продукции;

- создание проектных команд, включающих в себя представителей разных подразделений компании, по решению стратегических целей предприятия.

Европейская модель управления качеством, предложенная Европейским фондом управления качеством - EFQM (Europian Foundation for Quality Management), также связана с общими постулатами Э. Деминга. Методика EFQM предлагает структурированное множество критериев управления качеством и преследует следующие цели: удовлетворение потребностей клиентов, удовлетворение интересов персонала и социальное влияние на общество.

Модель базируется на следующих положениях:

- клиент - в центре внимания компании;

- эффективное сотрудничество с поставщиками;

- участие персонала, постоянное повышение квалификации;

- новаторство и постоянное совершенствование процессов;

- поэтапное, структурное достижение целей компании;

- взаимная ответственность руководителей и подчинённых.

Рассматривая отечественную практику применения систем управления качеством, можно выделить несколько основных концепций, оказавших сильное влияние на развитие промышленности.

Концепция бездефектного изготовления продукции (далее БИП) - это концепция бездефектной работы, внедрённая на пред- 
приятиях в Саратовской области, внедрённой в 1955 г. В основу было положено ужесточение мотивации для работников, предъявлявших дефектные изделия на производственной линии. При этом система стимулирования была направлена не на выявление дефектов продукции, а на устранение причин появления данных дефектов. Наказание способствовало работников соблюдать технологические дисциплины, а также указывать менеджменту на некачественные материалы, оснастку и неисправное оборудование.

Концепция Качество-Надёжность-Ресурс с первых изделий (далее КАНАРСПИ) - это концепция, основной задачей которой является выявление ещё на этапе проектирования возможных причин ухудшения качества и снижения надёжности продукции, выработка конструкторских и технологических мер, исключающих появление дефектов. Система была внедрена на Горьковском авиационном заводе. Основные принципы системы:

- универсальность (возможность использования в других отраслях промышленности);

- комплексное обеспечение качества продукции;

- развитие структуры постоянного совершенствования качества продукции и развития опытно-конструкторских разработок;

- организация всестороннего учёта качества выпускаемой продукции, на каждом этапе производства и разработки;

- привлечение клиентов к развитию и совершенствованию продукции;

- снятие с производства морально-устаревшей продукции;

- развитие высококачественных видов продукции.

В свою очередь, российская система управления качеством имела ряд недостатков, к которым можно отнести:

- слабое методическое руководство со стороны отраслевых организаций по управлению качеством и стандартизации; 
- безразличие руководителей предприятия к совершенствованию системы;

- недооценивание роли обучения персонала методам управления качеством;

- формальное отношение к организации системы управления качеством;

- передача работы по управление качеством на подразделение OTK;

- недостаточность стимулирования производства высококачественной продукцией.

Но самый главный недостаток - системы не были ориентированы на конечного потребителя. Однако, данные инструменты могут позволить достичь больших результатов в области развития промышленных предприятий.

В ходе написания магистерской диссертации была проведена оценка практического опыта применения концепции TQM на российском рынке. Полученные результаты представлены в табл. 11.

Результаты, проведённые в ходе оценки внедрения концепции TQM, полностью подтверждают принципы применения данного подхода. Принципы концепции ТQМ отражены на рис. 25.

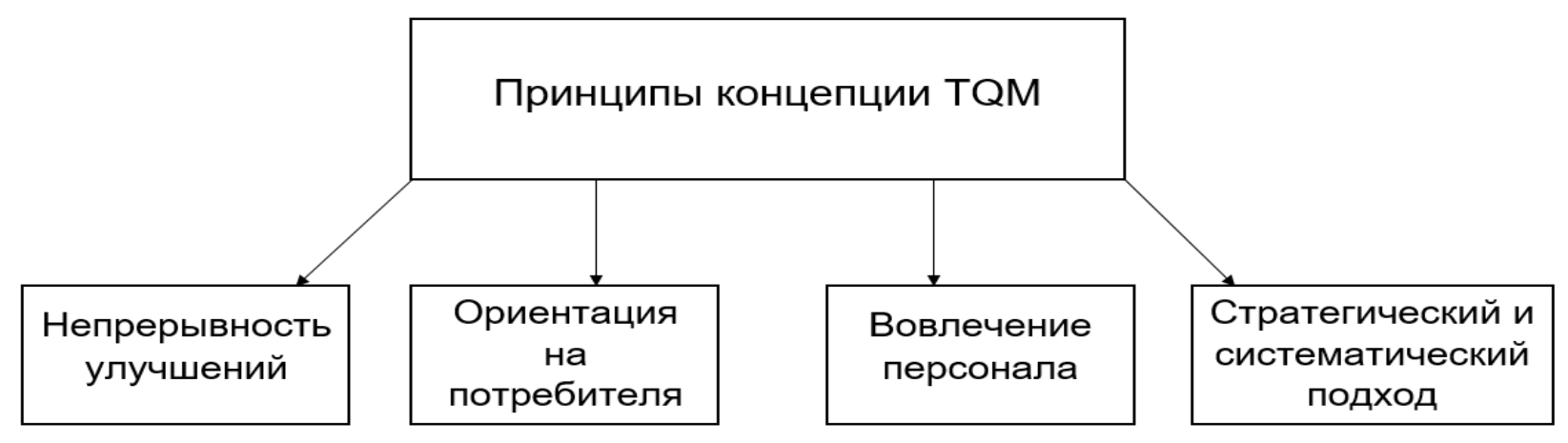

Рис. 25. Принципы концепции TQM 
Оценка российской практики применения концепции TQM

\begin{tabular}{|c|c|}
\hline Преимущества & Недостатки \\
\hline $\begin{array}{l}\text { - универсальность (возможность ис- } \\
\text { пользования в других отраслях про- } \\
\text { мышленности); } \\
\text { - комплексное обеспечение качества } \\
\text { продукции; } \\
\text { - развитие структуры постоянного со- } \\
\text { вершенствования качества продукции } \\
\text { и развития опытно-конструкторских } \\
\text { разработок; } \\
\text { - организация всестороннего учёта ка- } \\
\text { чества выпускаемой продукции, на ка- } \\
\text { ждом этапе производства и разработки }\end{array}$ & $\begin{array}{l}\text { - слабое методическое руководство со } \\
\text { стороны отраслевых организаций по } \\
\text { управлению качеством и стандартиза- } \\
\text { ции; } \\
\text { - безразличие руководителей предпри- } \\
\text { ятия к совершенствованию системы; } \\
\text { - недооценивание роли обучения персо- } \\
\text { нала методам управления качеством; } \\
\text { - формальное отношение к организации } \\
\text { системы управления качеством }\end{array}$ \\
\hline
\end{tabular}

\section{2. Анализ зарубежного и российского опыта применения концепции Хосин-Канри}

В середине XX века в результате развития отраслей промышленности Японии автомобильная компания “Тоуоta” столкнулась с большими объёмами перепроизводства продукции. Готовая продукция и комплектующие изделия превышали размеры отведённых складов. При этом процент производственного брака составлял высокие показатели, а количество операций по логистике, обработке и согласованию информации увеличивались, усложняя весь производственный цикл.

Проблема работы компании состояла в понимании стратегических целей и выведении чёткого алгоритма функционирования подразделений. Было выведено, что эффективность компании состоит не только в производстве качественной продукции, но и качественной организации бизнес-процессов на предприятии. В данной спе- 
цифике работы был выведен инструмент развёртывания стратегии промышленного предприятия Хосин-Канри. Для устранения проблемы перепроизводства и повышенных показателей дефектной продукции, были поставлены следующие задачи:

- сокращение времени изготовления одной единицы продукции и снижение издержек.

- повышение конкурентоспособности компании на долгосрочный период в условиях состояния рынка после Второй мировой войны.

Для решения установленных задач был произведен анализ и оптимизация цепочки создания ценности компании, определены «узкие места» в производственном цикле путем описания бизнеспроцессов, декомпозиции целей и разделения показателей до уровня драйверов первоначальных затрат, выполнен анализ узких мест и предложены основные положения по их ликвидации, в т.ч.:

- применена система управления запасами «точно-во-время»;

- внедрена система по контролю качества производимой продукции;

- сформирована система управления на различных уровнях менеджмента;

- разработаны мероприятия по ускорению процесса доведения целей высшего руководящего менеджмента до оперативного уровня цехов и участков.

В результате проведенных мероприятий компания «Toyota» достигла высоких показателей:

- снижение дефектов производства на 85\%;

- уменьшение длительности производительного цикла на 87\%;

- снижение издержек на 75\%;

- увеличение сроков передачи продукции на рынок. 
В компании «Тоуota» используют несколько видов документов, которые в своём составе имеют спектр информации о деятельности предприятия. На корпоративном уровне данные документы отражены в A3 форматах: план работы команды, отчет о показателях достижения результатов проекта, информационный отчет. Основную долю информации указанных отчётов составляют девять типовых элементов, требующихся для успешного выполнения проекта

Концепция Хосин-Канри приобрела широкое распространение у ведущих компаний Российской Федерации, однако каждая организация адаптирует инструмент для своих целей. Совместное применение нескольких инструментов построения системы управления не даёт необходимого синергетического эффекта, система имеет хаотичный характер. Данное явление обусловлено следующими причинами:

- отсутствие согласованного вектора и установленного видения конечной количественной цели проектов улучшений;

- искажение информации между подразделениями компании при установлении целей сверху-вниз, так и при суммировании информации об анализе результатов деятельности организации снизувверх;

- отсутствие заинтересованности исполнителей на местах, а также низкая мотивация, обусловленная недостаточным пониманием ценностей компании и своей роли в стратегическом видении организации. Слабая информативность о полученных результатах.

Предприятие ОАО «КамАЗ» применило концепцию ХосинКанри для оптимизации процесса сборки автомобильных шасси. Цели проекта: уменьшение себестоимости автомобильного шасси на величину, превышающую затраты на проект улучшений, методом ликвидации узких мест и ограничений системы при помощи инструментов операционного и производственного менеджмента, а также формирование компетенций у персонала организации в области опе- 
рационного и производственного. Для достижения установленных целей были выведены наиболее значимые этапы.

Необходимыми этапами проекта улучшений стали определённые тактические действия, для которых, кроме стандартных показателей (ресурсы и сроки), устанавливались КРI, дающие возможность оценивать уровень улучшения процессов. Каждый этап предусматривал конкретные действия, требуемые для достижения поставленных целей в указанные сроки. Были выделены наиболее важные этапы для эффективной реализации проекта. Итоговый документ отражал корреляцию поставленных целей, тактик и результатов проекта улучшений, помогал оценить результаты работы всех участников проекта, а также периодически производить мониторинг за командами исполнителей, ответственных за деятельность конкретных участков работы. Полученные результаты также были прописаны в итоговой X-матрице.

В ходе совместной работы участники пришли к выводу, что концепция Хосин-Канри, позволила достичь следующих результатов:

- сфокусировать деятельность организации не на тривиальных проектах, а на взаимосвязанных с поставленными целями;

- визуализировать стратегическое видение компании;

- вовлекать весь персонал в выполнение прорывных задач;

- постоянно совершенствовать процесс планирования и организации;

- анализировать и понимать полученные результаты, выявлять проблемы, возникшие во время предшествующего цикла внедрения;

- проводить непрерывное обучение персонала компании.

Концепция Хосин-Канри была также применена на промышленных машиностроительных предприятиях на российском рынке. 
Для всех дочерних предприятий ЗАО «Трансмашхолдинг», к которым относится Брянский машиностроительный завод, управляющая компания установила глобальные цели и стратегические направления на 2014 - 2016 гг., в частности развитие сотрудников компании, повышение качества выпускаемой продукции, система управления затратами и внедрение проектного менеджмента. Для конкретно рассматриваемого предприятия актуальной стратегической задачей, наряду свыше перечисленными, является завершение масштабной реструктуризации. С целью выстраивания внутренней коммуникации и реализации стратегии был разработан проект, названный «Путь 2016», включающий ежегодные преобразования на конкретных областях деятельности.

Для выполнения достижений целей и стратегии, указанных руководством, были сформулированы задачи, такие как: совершенствование системы производственного планирования, управление эффективность использования оборудования, повышение энергоэффективности предприятия и др. По каждой из тактик назначен ответственный директор по направлению и сформированы КРІ, ключевые показатели эффективности, которые представлены в табл. 12.

Таблица 12

Цели механического участка тележного цеха на 2016 год [73, с. 30]

\begin{tabular}{|c|c|}
\hline 5. & 2016 г. \\
\hline $\begin{array}{l}\text { Эффективность производственных ра- } \\
\text { бочих }(1,0) \\
\text { Общая эффективность оборудования - } \\
80 \% \text { (коэффициент готовности обору- } \\
\text { дования } 85 \%)\end{array}$ & $\begin{array}{l}\text { KPI 1. Эффективность производственных } \\
\text { рабочих } \\
\text { KPI 2. Ставка полного нормо-часа }\end{array}$ \\
\hline [C - не менее 3 по тематике & KPI \\
\hline $\begin{array}{l}\text { Т загрузки технологического } \\
\text { я-85\% }\end{array}$ & $\begin{array}{l}\text { KРI 4. Оборачк } \\
\text { производства }\end{array}$ \\
\hline полнения произво & $\begin{array}{l}\text { КРІ 5. Доля производственных расходов в } \\
\text { себестоимости }\end{array}$ \\
\hline о ППУ - 59 шт. & иых произ- \\
\hline & \\
\hline $\begin{array}{l}\text { Количество дней } \\
\text { них }-365 \text { дней }\end{array}$ & ремонт/ товарный выпуск) \\
\hline
\end{tabular}


После разработки матрицы генерального директора было проведено расширенное информационное собрание с руководителями предприятий всех уровней, где представлен стратегический план развития компании; цели на ближайший год. Далее директора подразделений составили $\mathrm{X}$-матрицы на уровни бюро и участков. Такой плавный спуск показателей позволил ЗАО «Трансмашхолдинг» довести цели и задачи до персонала. За счет этого все сотрудники стали ощущать свой личный вклад в стратегическое развитие предприятия. В целом «пробное» использование Х-матриц в 2015 г. позволило компании:

- повысить уровень информированности сотрудников о целях, задачах и перспективах развития организации - с $18 \%$ до $82 \%$;

- создать процессы преобразования (постоянного совершенствования) во всех направлениях деятельности компании;

- скоординировать ответственность и работу различных подразделений для достижения общих целей предприятия;

- изменить систему мотивации персонала предприятия;

Предприятие «Оконный континент», находящееся в г. Обнинске Московской области, уже на протяжении более четырех лет внедряют и эффективно используют методику Хосин-Канри, а также инструменты бережливого производства.

Это предприятие существует на рынке семь лет, и выпускает различные типы окон, а также осуществляет монтаж и послегарантийное обслуживание. Основание компании пришлось на время кризиса 2008 г., и для того чтобы остаться на рынке, необходима была система, позволяющая приспосабливаться к изменениям гибко и в короткие сроки.

По причине отсутствия у молодого предприятия такой системы выходило много брака, заказы часто срывались или переносились, из-за того, что не успевали вовремя производить. На заводе работали 
три производственные линии, однако операторы работали в сезон продаж с 8 до 22 часов.

Для того чтобы стать компании эффективной, необходимо сделать так, чтобы в продукте осталось только то, что система признает качественным, нужно убрать то, что она не считает ценным для себя, - потери, скрывающиеся в процессах.

Руководство компании, приняло решение осваивать концепцию бережливого производства, так как выявленная причина является одним из ее принципов. В компании осенью 2008 года была сформулирована миссия, направленная на способствование:

- общему росту компании, добавляя ценность для потребителей;

- стабильности и благополучию членов команды;

- экономическому развитию общества и регионов, в которых компания ведет свою деятельность.

Для развертывания миссии нужна была простая и понятная система, позволяющая организовать визуальную информированность об управлении процессами. Данные свойства присущи системе Хосин-Канри, которую стали реализовывать с апреля 2010 г.

Первоначально была составлена Х-матрица, содержащая долгосрочные и среднесрочные стратегии, тактики и мероприятия для их достижения.

В ходе анализа текущей ситуации удалось выявить причину бракованного продукта и задержки по временным срокам, заключающуюся в плохой связи между собой системы поставок, производства и продаж. Для решения проблемы руководство сформулировало стратегию 2010-2012 г., которая заключается в интеграции отдельных компонентов компании в единую систему - выстраивание процесса в виде потока создания ценности.

Один из первых проектов касался поставок. Его цель - улучшение качества доставки изделий. В связи с этим был разработан осо- 
бый тип поставки для перевозки окон, позволяющий не повреждать их при транспортировке. Следующим этапом стало создание потока, но первоначально он не был равномерным, часто случались авралы и простои оборудования. Для выравнивания производства были проведены анализ времени такта и определение состава питча (система пропорций окон).

В 2013 году, были получены первые результаты. На каждое изделие тратилось в среднем 3,2 мин. при такте 3,1 мин., это значит, что каждое изделие изготавливалось на 4 секунды дольше. Следовательно, для выполнения заказа рабочим приходилось задерживаться после смены на 14,67 мин. Первый питч выпал на сентябрь 2013 г., а к ноябрю их было уже 40\%. При этом сократилось время производства одного изделия до 2,87 мин., а в апреле при доле питчей 100\% время одного составило 2,72 мин. Операторы стали меньше уставать, за счет чего, сократилась доля брака.

\section{3. Взаимодействие инструментов в комплексе практического внедрения концепции TQM}

Концепция TQМ требует чёткого следования правилам её внедрения. Одним из ключевых параметров является процессный подход к применению постулатов и инструментов концепции. Это подход к анализу и организации деятельности компании, базирующийся на рассмотрении бизнес-процессов, каждый из которых взаимодействует с другими бизнес-процессами, взаимосвязанными друг с другом, а также с внешней средой. Хосин-Канри, как инструмент развёртывания стратегии предприятия, обладает данным качеством и демонстрирует взаимодействие этих методов. В тоже время, для эффективного анализа данных требуется помощь иных инструментов, учитываемых в работе Хосин-Канри. Одним из таких элементов являются ключевые показатели эффективности. 
Ключевые показатели эффективности (KPI) - показатели, поддающиеся количественному измерению и считающиеся наиболее важным для оценки эффективности деятельности фирмы, отдела или сотрудника. Они позволяют свести представления о том, как нужно функционировать, к единому пониманию, придать целевую направленность деятельности сотрудников, подразделений, рабочих групп. При создании системы КРI очень важно, чтобы используемые показатели были понятны всем сотрудникам, участвующим в этом процессе.

Ключевые показатели эффективности интегрируются в Х-матрицу концепции Хосин-Канри Задачей владельца процесса, регулирующего данные матрицы, является мониторинг показателей согласно установленным годовым стратегическим целям и выведенным проектам. Отслеживание параметров проходит на основе плановых показателей; фактических, полученных в ходе реализации проектов после определённого периода времени; отклонений от заданных значений.

Каждая стратегическая цель декомпозируется до конкретного проекта. Владелец процесса задаёт индикаторы по достижению конкретных целей. Полученные данные входят в композицию с другими проектами, тем самым создают массив информации по общей стратегической цели. Задача KPI - максимально точно и быстро донести полученную информацию по целям до владельца процесса. В результате чего, в итоговой матрице на основе показателей формируется общее состояние предприятия, демонстрируется достижение целей и наличие отклонений. Взаимодействие данных инструментов требует слаженной структуры и четко сбалансированных показателей, заданных на каждом из уровней матрицы.

Выделяются следующие виды ключевых показателей:

- KPI результата - сколько и какой результат произвели; 
- KРІ затрат - сколько ресурсов было затрачено;

- KPI функционирования - показатели выполнения бизнеспроцессов (позволяет оценить соответствие процесса требуемому алгоритму его выполнения);

- KPI производительности - производные показатели, характеризующие соотношение между полученным результатом и временем, затраченным на его получение;

- KPI эффективности (показатели эффективности) - это производные показатели, характеризующие соотношение полученного результата к затратам ресурсов.

При разработке показателей процесса необходимо придерживаться следующих правил:

- набор показателей должен содержать минимально необходимое их количество для обеспечения полноценного управления бизнес-процессом.

- каждый показатель должен быть измерим;

- стоимость измерения показателя не должна превышать управленческий эффект от использования данного показателя.

Одним из ярких примеров внедрения KPI на российском рынке стала компания ПАО «Газпром» - крупнейшее предприятие Российской Федерации, мировой лидер отрасли, один из лидеров по технологической оснащённости и охвату рынка. Введение системы оценки и мониторинга бизнес-процессов и показателей эффективности - это правительственная линия, таким образом, ПАО «Газпром», как организация, главным акционером которой является государство, в лице Росимущества, применила данные инструменты.

Система КРI была введена в ОАО «Газпром» в «Программе инновационного развития», принятой в 2011 году. В ходе проведенного технического аудита и на основе опыта зарубежных компаний газо- 
вой отрасли были разработаны 7 основных групп КРI, которые охватывают все области деятельности ОАО «Газпром»:

- доля затрат на НИОКР в выручке;

- снижение эксплуатационных затрат в проектах за счет применения инновационных технологий;

- снижение удельного расхода топливно-энергетических ресурсов на собственные технологические нужды и потери;

- снижение удельных выбросов парниковых газов в $\mathrm{CO}_{2}$-эквиваленте;

- частота несчастных случаев на производстве;

- прирост количества используемых патентов и лицензий;

- рост производительности труда.

В результате ввода в практику и применения результатов КРI ОАО «Газпром» заметно улучшила свою научную инновационную деятельность: в мае 2012 года по рейтингу программ инновационного развития российских компаний с государственным участием заняла 5-е место и получила оценку 3,7 балла из 5. А к 2020 году OAО «Газпром» планирует улучшить эти показатели до максимума.

Важным элементом совершенствования производственного процесса предприятия является стандартизированная работа. Процесс должен иметь чёткий алгоритм выполнения, должен быть структурированным и понять каждому члену компании. Перед тем, как улучшать систему, требуется описать каждый бизнес-процесс, с целью нахождения отклонений от основной линии выполнения.

Бизнес-процесс обладает рядом характеристик:

- обладает определённой целью, взаимосвязанной с целями компании;

- за каждым процессом закреплён владелец, который отвечает за его исполнение; 
- ресурсы, которые подключены к выполнению процесса;

- система контроля и показателей выполнения.

Совокупность всех действий по преобразованию материалов и информации в законченный продукт для клиента называется потоком создания ценности, который изображают в виде карты бизнеспроцессов. Карта позволяет увидеть поток создания ценности, проанализировать взаимосвязь процессов и возможности по улучшению системы. Пример такого механизма продемонстрирован на рис. 26, на примере компании АО «Группа СВЭЛ».

Данный инструмент позволил выявить четкую структуру организации, а также создать базу для описания бизнес-процессов компании.

Технология описания бизнес-процессов делает все операции прозрачными и понятными, позволяет проводить анализ и выявлять проблемы, приводящие к сбоям. Главная задача - выявить зоны взаимодействия между подразделениями предприятия с целью ликвидации потерь в совместной работе, а также упрощению работы персонала и адаптации новых сотрудников.

Целью описания бизнес-процессов является выявление связей между предпринимаемыми действиями, а не фиксирование мельчайших подробностей деятельности персонала. Описание рекомендуется стандартизировать, используя стандартные формы. Можно выделить следующие разделы описания:

- создание стандартных форм бизнес-процессов;

- построение карты бизнес-процесса;

- построение маршрутов бизнес-процесса;

- построение матриц бизнес-процесса;

- построение блок-схем бизнес-процесса;

- описание стыков бизнес-процессов; 


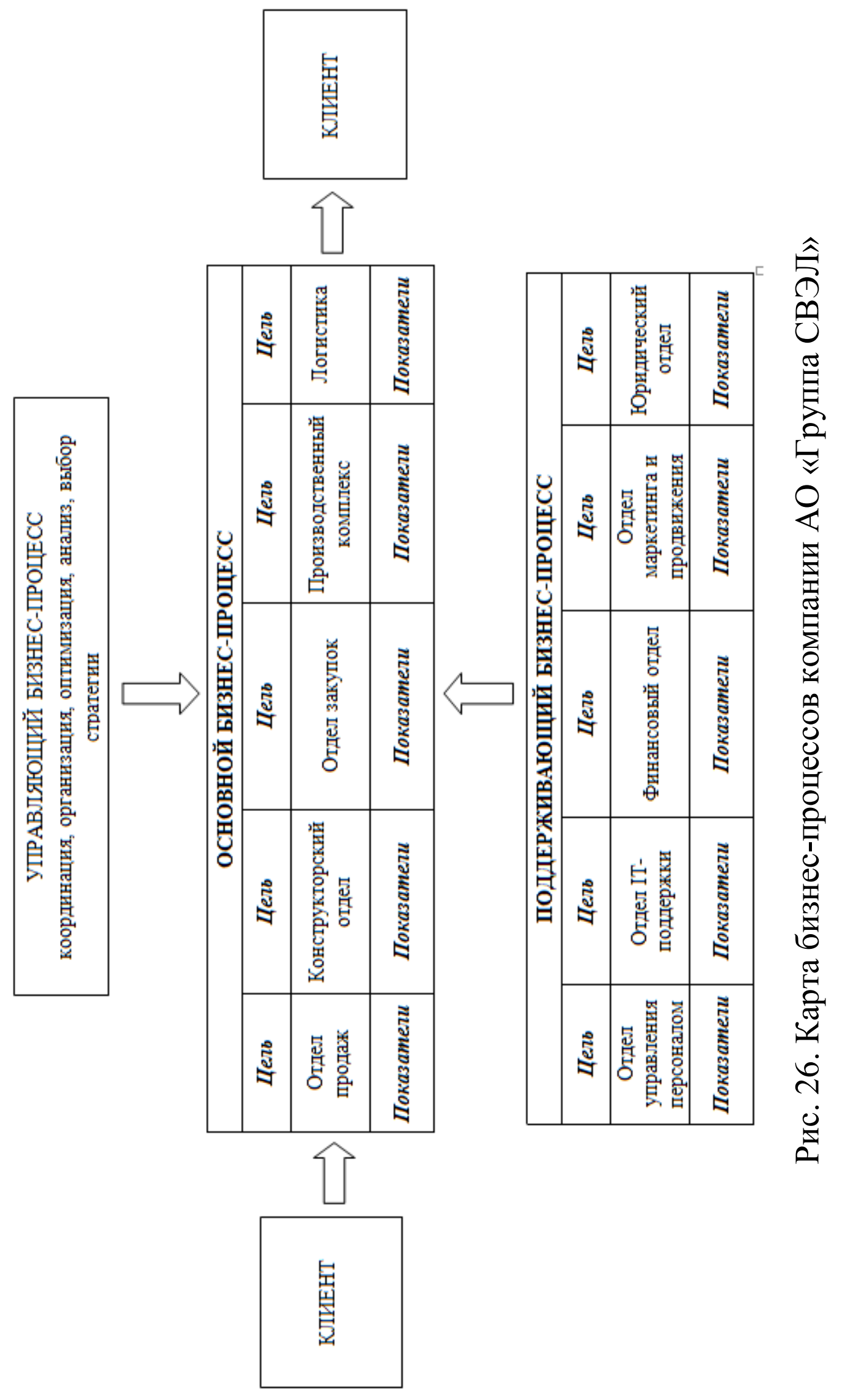


- вспомогательные описания бизнес-процесса;

- развёрнутое описание бизнес-процесса;

- документирование бизнес-процесса;

- определение показателей и индикаторов бизнес-процесса;

- регламент выполнения бизнес-процесса.

В качестве инструмента описания бизнес-процесса наиболее эффективным является методология IDEF0. Методология нашла широкое признание и применение, в первую очередь, благодаря простой графической нотации, используемой для построения модели. Главными компонентами модели являются диаграммы. На них отображаются функции системы в виде прямоугольников, а также связи между ними и внешней средой посредством стрелок. Использование всего лишь двух графических примитивов (прямоугольник и стрелка) позволяют быстро объяснить правила и принципы построения диаграмм IDEF0 людям, незнакомым с данной методологией. Это достоинство позволяет подключить и активизировать деятельность заказчика по описанию бизнес-процессов с использованием формального и наглядного графического языка. Главной задачей данного инструмента является стандартизация бизнес-процессов на промышленном предприятии. Это необходимо для поиска узких мест в производственном процессе с последующим устранением, либо оптимизации. На рис. 27 показаны основные элементы графической нотации IDEF0.

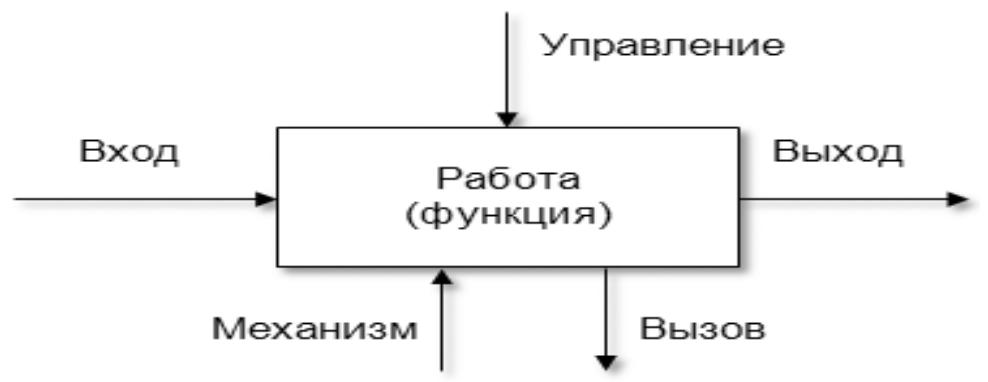

Рис. 27. Элементы графической нотации IDEF0 [54] 
Прямоугольник представляет собой работу (процесс, деятельность, функцию или задачу), которая имеет фиксированную цель и приводит к некоторому конечному результату. Имя работы должно выражать действие (например, «Изготовление детали», «Расчет допускаемых скоростей», «Формирование ведомости ЦДЛ № 3»).

Взаимодействие работ между собой и внешним миром описывается в виде стрелок. В IDEF0 различают 5 видов стрелок:

- вход (англ. input) - материал или информация, которые используются и преобразуются работой для получения результата (выхода). Вход отвечает на вопрос «Что подлежит обработке?». В качестве входа может быть как материальный объект (сырье, деталь, экзаменационный билет), так и не имеющий четких физических контуров (запрос к БД, вопрос преподавателя). Допускается, что работа может не иметь ни одной стрелки входа. Стрелки входа всегда рисуются входящими в левую грань работы;

- управление (англ. control) - управляющие, регламентирующие и нормативные данные, которыми руководствуется работа. Управление отвечает на вопрос «В соответствии с чем выполняется работа?». Управление влияет на работу, но не преобразуется ей, т.е. выступает в качестве ограничения. В качестве управления могут быть правила, стандарты, нормативы, расценки, устные указания. Стрелки управления рисуются входящими в верхнюю грань работы. Если при построении диаграммы возникает вопрос, как правильно нарисовать стрелку сверху или слева, то рекомендуется ее рисовать как вход (стрелка слева);

- выход (англ. output) - материал или информация, которые представляют результат выполнения работы. Выход отвечает на вопрос «Что является результатом работы?». В качестве выхода может быть как материальный объект (деталь, автомобиль, платежные документы, ведомость), так и нематериальный (выборка данных из БД, 
ответ на вопрос, устное указание). Стрелки выхода рисуются исходящими из правой грани работы;

- механизм (англ. mechanism) - ресурсы, которые выполняют работу. Механизм отвечает на вопрос «Кто выполняет работу или посредством чего?». В качестве механизма могут быть персонал предприятия, студент, станок, оборудование, программа. Стрелки механизма рисуются входящими в нижнюю грань работы;

- вызов (англ. call) - стрелка указывает, что некоторая часть работы выполняется за пределами рассматриваемого блока. Стрелки выхода рисуются исходящими из нижней грани работы.

Опыт показал, что, несмотря на кажущуюся простоту и формальность этого уровня, на нем часто приходится подолгу задерживаться, так как здесь должны быть отражены все значимые для собственника и рынка результаты. Ошибка может привести к созданию моделей, не выполняющих поставленные перед бизнесом задачи. Чтобы проверить, что значимые потоки отражены, необходимо убедиться, что на схеме присутствуют все 4 основные вида потоков:

- материальный: материалы и комплектующие на входе и готовая продукция на выходе;

- клиентский: потенциальный клиент на входе и удовлетворенный на выходе;

- финансовый: на входе это обычно инвестиции, платежи клиентов (выручка), кредиты и прочие доходы; на выходе - это платежи поставщикам, налоги, платежи по кредитам и прибыль;

- информационный: на входе это все потоки информации о внешней среде (состояние рынка, поведение конкурентов, технологические инновации и пр.), а на выходе - это поток информации, которую компания сообщает о себе миру (вся рекламная информация, а также все виды отчетности перед контролирующими органами). 
Большой опыт использования данной нотации на практике позволяет сделать следующие выводы:

- модель обладает хорошим визуализирующим потенциалом, но, на мой взгляд, большее ее значение - в дисциплинирующем эффекте. Заложенные в методологию правила и ограничения заставляют выработать системное и строгое отношение к моделям, что очень хорошо сказывается на качестве конечного результата;

- модель позволяет выстроить потоки связи между внешне не сильно связанными вещами: связать подсистемы фронт и бэкофисов с управлением, что гораздо хуже удается другим нотациям;

- подход прост и понятен для большинства участников проекта. Построение и чтение диаграмм в данной нотации ограничивается только желанием вникать в хитросплетение потоков бизнеса.

Некоторые из названных аргументов заставляют думать, что данный подход является лучшим и единственным для полного моделирования деятельности. Но не нужно забывать, что функциональная модель рассчитана только для верхнего уровня моделирования. Использование нотации IDEF0 для проектирования работы на уровне исполнителей ведет к тому, что схемы получаются чисто иллюстративными, и на их основе невозможно построить толковый регламент, так как они не содержат:

- конкретизации событий запуска и остановки процесса;

- условий перехода от одних действий к другим;

- возможности наглядно отобразить все ресурсы и исполнителей без перегрузки схемы стрелками.

Поэтому если пользоваться данной нотацией для тех задач, для которых она предназначена, то IDEF0 - практически единственная на сегодня нотация, которая позволяет сделать это содержательно и аккуратно. 
Согласно исследованию, организованному ассоциацией ВРМпрофессионалов АВРMP Russia «Российский рынок ВРМ 2015» в $32 \%$ российских компаний процессное управление применяется для отдельных, ключевых бизнес-процессов, в 26\% - ключевые бизнес-процессы регламентированы и в целом обеспечивают достижение целей, в $23 \%$ - процессное управление отсутствует, но есть понимание необходимости, а в $14 \%$ вопрос внедрения процессного управления не рассматривается.

Наиболее востребованной функцией до настоящего времени остается описание бизнес-процессов. Для организации управления бизнес-процессами $79 \%$ компаний занимаются их документированием, $46 \%$ - согласованием с информационными системами, $42 \%$ оптимизацией, $40 \%$ - стандартизацией. 


\section{ГЛАВА 6. МЕТОДИЧЕСКИЙ ПОДХОД К УПРАВЛЕНИЮ БИЗНЕС-ПРОЦЕССАМИ НА МАЛОМ ИННОВАЦИОННОМ ПРЕДПРИЯТИИ НА ОСНОВЕ КОНЦЕПЦИИ ТQМ}

\section{1. Методическое обеспечение системы управления бизнес-процессами на основе концепции ТQM}

В настоящее время российские предприятия находятся в стадии развития организационных бизнес-процессов. Экономическая среда заставляет компании «идти в ногу со временем». Оптимизация бизнес-процессов, стандартизация работы помогает предприятиям сократить затраты на производство и улучшить качество выпускаемой продукции за счёт сокращения потерь.

Российские предприятия, используя зарубежный опыт организационного развития компании, применяют подходы и инструменты, зарекомендовавшие себя как эффективное решение проблем. К сожалению, рассматривая направление управления качеством на промышленных предприятиях, можно сделать вывод, что при совершенствовании бизнес-процессов инструменты применяются хаотично.

В деятельности малых предприятий часто применяются «интуитивные» технологии управления. А при применении тех или иных инструментов, предназначенных для повышения эффективности и качества управления, отсутствует системный взгляд на организуемые процессы и применяемые инструменты. Для предприятий инновационной направленности это особенно значимо.

Каждый элемент развития производственной системы - часть общего системного подхода к решению проблем компании. Системный подход - направление методологии научного познания, в основе которого лежит рассмотрение объекта как системы: целостного комплекса взаимосвязанных элементов [74, с. 7]. 
В качестве примера рассмотрим инструменты «бережливого производства», которые в настоящее время имеют тенденцию активного внедрения на промышленных предприятиях Российской Федерации. По данным исследования Института комплексных стратегических исследований (ИКСИ) о распространении бережливого производства в России в марте-апреле 2010 года, из 735 опрошенных российских промышленных предприятий 32\% использовали японский опыт. В марте-апреле 2012 года был проведён повторный опрос, в результате которого выяснилось, что за 2 года количество предприятий, использующих бережливое производство, сократилось с $32 \%$ до $26 \%$, в то время как использование других методов улучшения организации увеличилось [75]. Данная тенденция обусловлена отсутствием быстрых результатов, причиной чего часто является отсутствие комплексного подхода к применению инструментов. Аналогичные результаты наблюдаются при применении отдельных постулатов системы TQM без системного подхода.

При внедрении инструментов и подходов важно понимать коренную причину несоответствия, которая подлежит исправлению. Руководство предприятия должно понимать, для чего требуются подобные преобразования, какие цели ставит перед собой компания, какие инструменты будут являться связующими в достижении желаемого состояния организации.

Совершенствование системы управления бизнес-процессами требует не только разработки методического обеспечения для функционирования этой системы, в основу которой, на наш взгляд, может быть положена концепция TQM, но и детальной проработки последовательности шагов по внедрению этой системы в практику работы малого инновационного предприятия.

Методическое обеспечение управления бизнес-процессами предприятия на базе TQM должно интегрировать целый комплекс методов и инструментов, системное применение которых позволит 
обеспечить эффективное функционирование и взаимодействие всех структурных элементов и процессов на предприятии. Помимо концептуальных и методических основ TQM к числу этих инструментов относятся:

- метод Хосин-Канри (Х-матрица);

- циклы PDCA;

- моделирование бизнес-процессов посредством функциональных моделей IDEF0 и карты потока создания ценности;

- система КРI;

- диаграмма Исикавы;

- контрольные карты Шухарта.

Графически методическое обеспечение системы управления бизнес-процессами на промышленном предприятии представлено на рис. 28.

Совокупность элементов системы образует цепь циклически повторяющихся шагов (этапов), реализация каждого из которых требует применения своих инструментов. При этом этапы имеют различную цикличность в своей реализации с уменьшением продолжительности цикла по мере прохождения вниз по элементам системы:

a) формирование долгосрочного стратегического видения предприятия (миссии, ценности);

б) проведение анализа внутренней и внешней среды предприятия для определения стратегии развития (определение технического состояния и вариантов достижения целей);

в) на основе установленного стратегического видения формирование долгосрочных стратегических целей компании, которые впоследствии будут декомпозированы до уровня линейного менеджмента; 


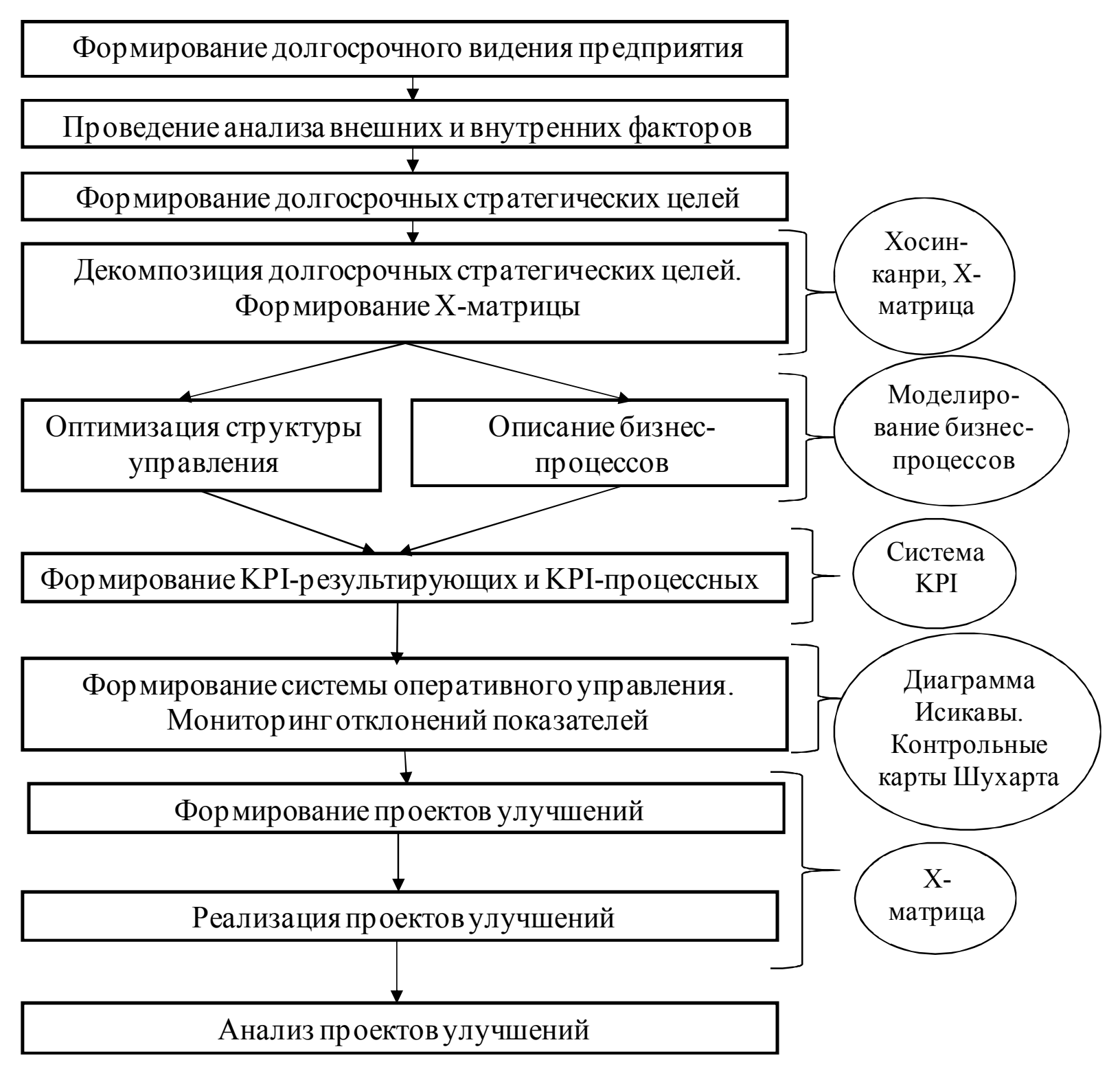

Рис. 28. Система управления бизнес-процессами на промышленном предприятии

г) формализация полученных данных в формате концепции Хосин-Канри (Видение - Стратегии - Тактики), формирование X-матрицы;

д) моделирование и описание бизнес-процессов. Стандартизация работ по процессам (формирования требований к процессам, установка критериев качества). Оптимизация структуры управления. Формирование КРI - процессных, KРI - результирующих; 
ж) формирование системы оперативного управления: мониторинг КРI, мониторинг отклонений показателей, выявление причин несоответствий. Установка сроков мониторинга полученных данных;

3) формирование системы проектного улучшения на основе составления матрицы оперативного менеджмента, реализация проектов улучшений. Анализ реализации проектов.

Рассмотрим подробное содержание каждого элемента (этапа).

Этап а) системы состоит в формировании долгосрочного стратегического видения предприятия. Миссия предприятия - это корпоративная идеология, ценностями которой соответствуют сотрудники предприятия, философия которой отражается в их работе. Это идеологический стержень компании, опираясь на который происходит принятие решений о развитии организации. Миссия компании в большей степени ориентирована на конечного потребителя, имеет социальную или техническую составляющую деятельности, в то время как стратегическое видение акцентирует внимание на принципах взаимодействия, которые помогают в реализации миссии компании. Основной характеристикой видения предприятия являются составляющие долгосрочного курса, направления видов деятельности компании.

Пункт б) системы состоит в проведении анализа внешней и внутренней среды предприятия для определения стратегии развития, а также определения финансового и технического состояния, а также варианты стратегий достижения поставленных целей. Желаемое состояние организации в будущем должно соответствовать возможностям предприятия по достижению целей. В качестве метода анализа внешней и внутренней среды предприятия следует применить инструменты: SWOT-анализ, PEST-анализ. Для определения технического состояния оборудования предприятия следует провести комплекс мероприятий, например, по изучению данных 
производительности оборудования, частоты вывода в ремонт агрегатов, количество брака по технологической цепочке.

Этап в) системы описывает формирование стратегических целей компании, формирование показателей по их достижению. Стратегические цели компании устанавливаются на длительный период: чего необходимо достичь, чтобы приблизиться к состоянию ожидаемой действительности, максимально соответствовать заданному видению. Впоследствии данные цели будут декомпозированы на структурные части, каждая из которых будет давать результат, в совокупности отражающий общую картину достижения отдельной стратегической цели. Декомпозированные элементы - конкретные проекты улучшений.

Стратегические цели должны затрагивать общую картину в целом по предприятию. В свою очередь, декомпозиция подразумевает распределение задач по каждому структурному подразделению. Это сделано для полного вовлечения каждого сотрудника в ценности организации.

В основу этапа г) заложена формализация полученных данных в формате инструмента Хосин-Канри (видение - стратегии - тактики - проекты). В основу формализации стратегических целей компании, их декомпозиции, формировании плановых, фактических показателей, а также отклонений положен инструмент развёртывания стратегической политики предприятия Хосин-Канри. Формализация данных будет представлена в итоговом документе - Х-матрице.

На рис. 29 представлен шаблон матрицы развёртывания стратегии предприятия, подготовленный в рамках выполнения научной работы. Данный шаблон соответствует матрице 0-го уровня. Ответственность за формирование документа лежит на владельце процесса - генеральном директоре, руководителе проекта. Центр матрицы описывает видение компании на долгосрочный временной 
период. Также продемонстрированы 4 раздела: стратегические цели, годовые цели, стратегии, мониторинг.

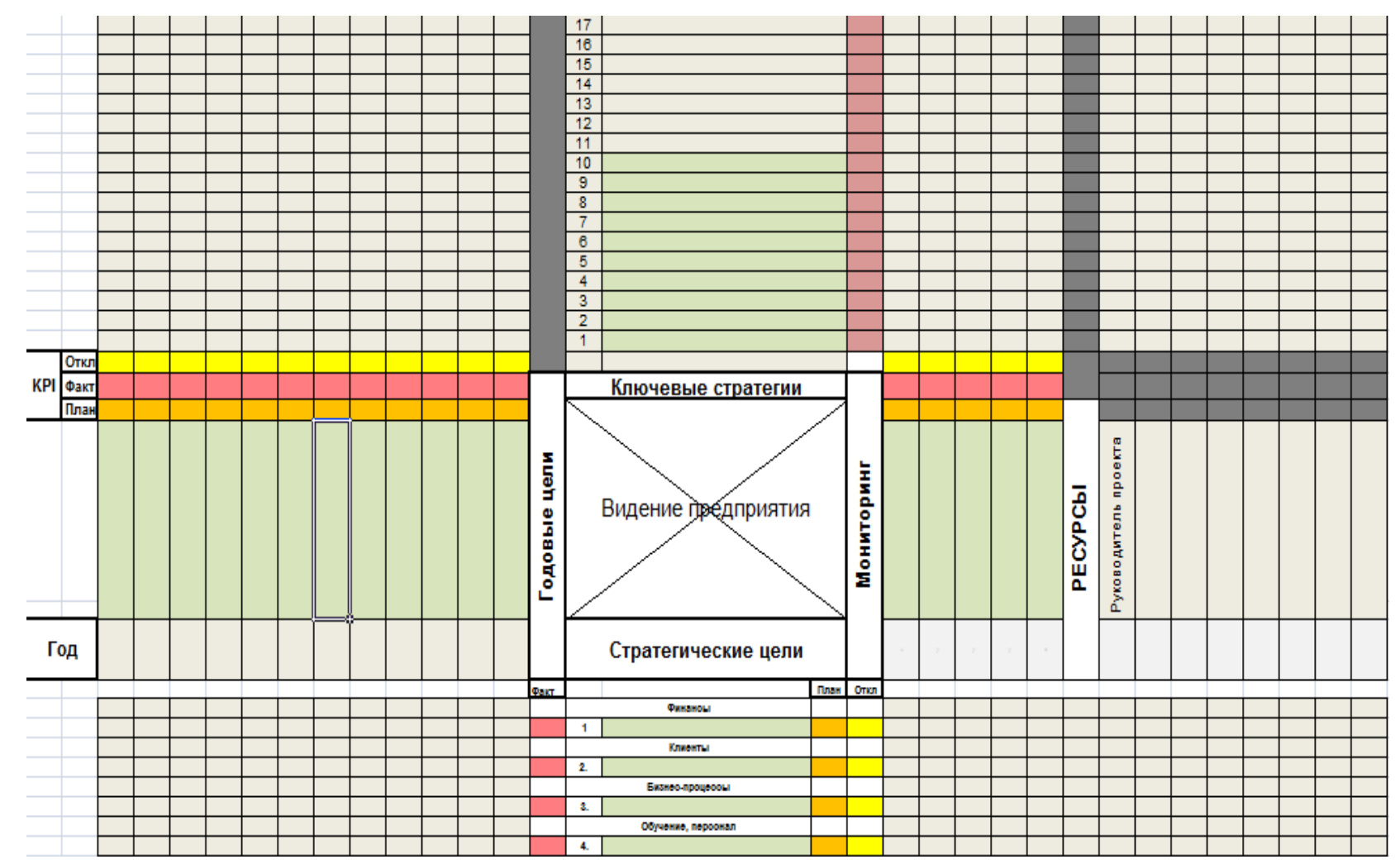

Рис. 29. Шаблон матрицы развёртывания стратегии предприятия

Стратегические цели - это ключевые части деятельности организации, способные привести компанию к достижению состояния видения. Следующий раздел - годовые цели. Каждый пункт должен описывать конкретную цель со временем реализации и ключевыми показателями достижения. Для каждой задачи устанавливаются ключевые стратегии. Как для достижения стратегической цели может быть несколько годовых целей, так и для годовой цели несколько ключевых стратегий. Заключительный раздел - мониторинг, включающий в себя целевые показатели, выраженные в количественном выражении на основе выработанных ключевых показателей эффективности.

Все разделы взаимодействуют между собой. Столбцы, выделенные оранжевым цветом, показывают плановые показатели, за- 
данные владельцем процесса и членами команд. Розовым цветом раздел фактически выполненных показателей, а жёлтым - отклонения плановых значений от фактических.

На рис. 30 представлены области корреляций разделов. Взаимосвязь указана на пересечении пунктов, а именно целей, стратегий и мониторинга, а также стратегий и целей. Каждая корреляция показывает сильное взаимодействие (цифра 3), умеренное взаимодействие (цифра 1) и отсутствие взаимодействия (цифра 0). Раздел «ресурсы» описывает членов команд для соответствующей матрицы. Для матрицы 0-го уровня таковыми являются заместители генерального директора, такие как директор по производству, директор по персоналу, коммерческий директор. Далее, матрица 1-го уровня формируется каждым из членов команд для своего подразделения.

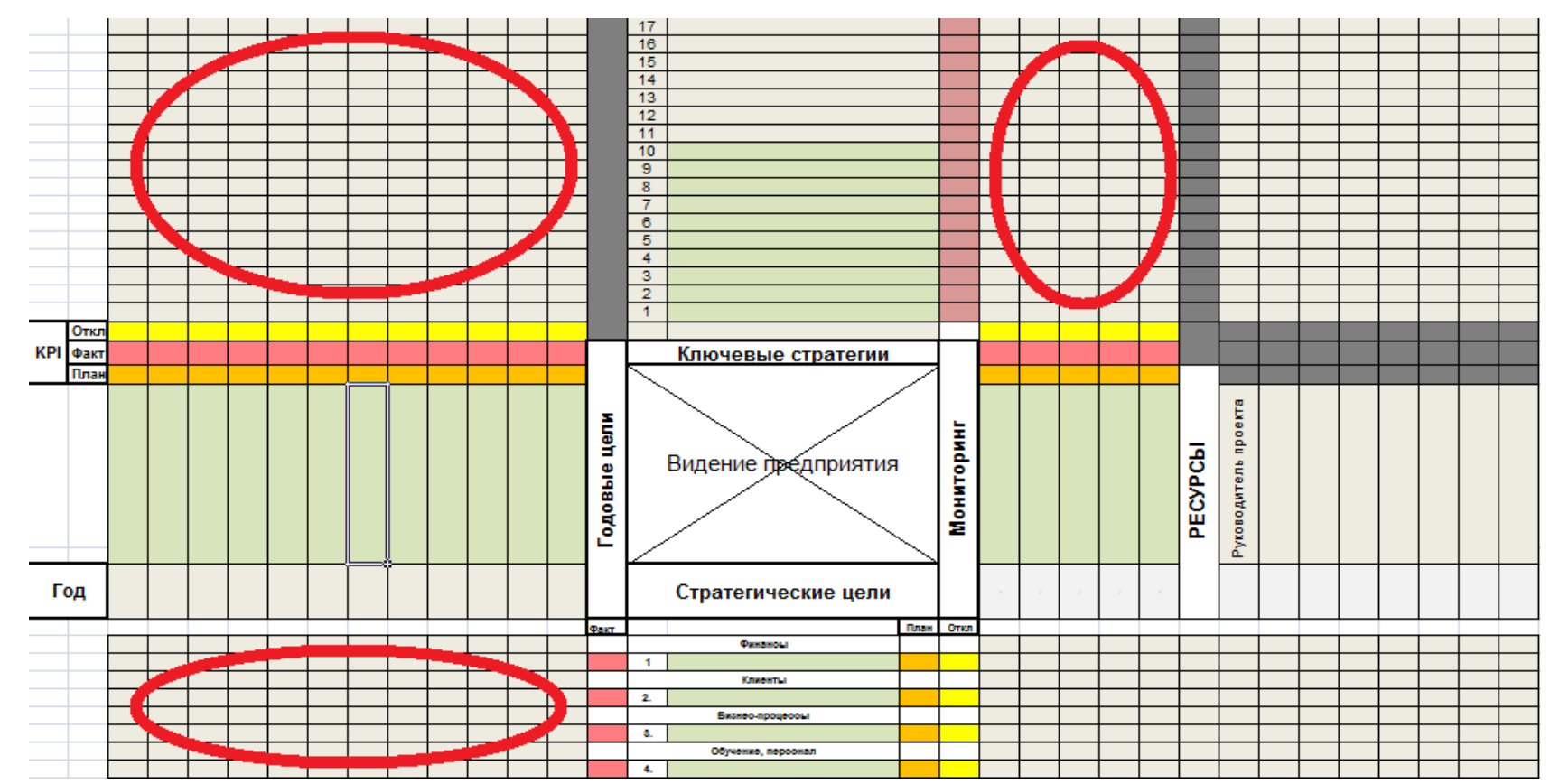

Рис. 30. Корреляция разделов в матрице

Матрицы 1-го уровня и 2-го уровня, представленные соответственно на рис. 31 и 32, поворачиваются на 90 градусов против часовой стрелки. 


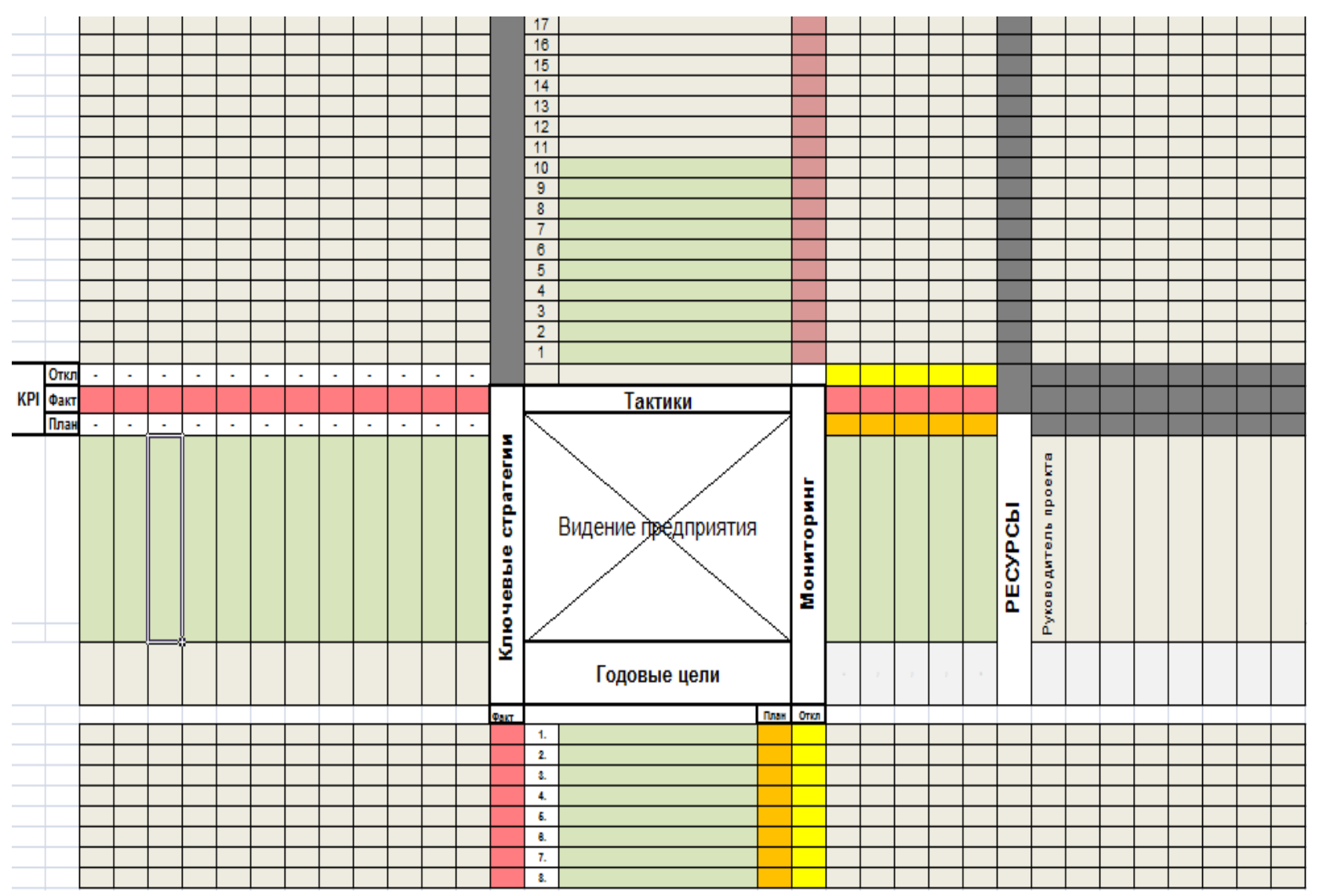

Рис. 31. Шаблон матрицы до уровня тактик

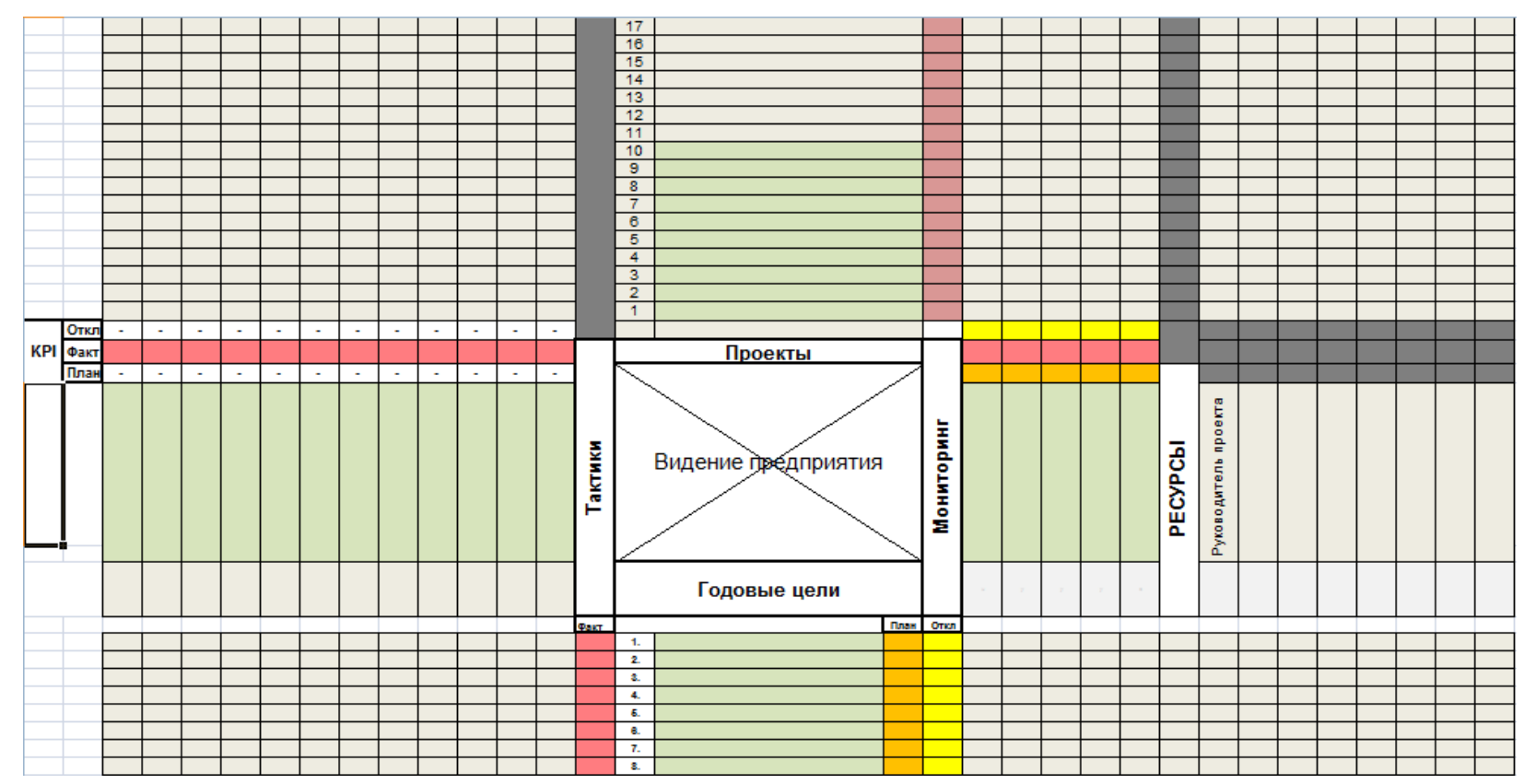

Рис. 32. Шаблон матрицы до уровня проектов

Главная цель данного процесса - декомпозировать стратегические цели до уровня конкретных проектов. Количество уровней мат- 
рицы зависит от организационной структуры предприятия и, по возможности, цели могут быть декомпозированы до оптимального уровня, наиболее подходящего для оперативного персонала. На каждом уровне владелец процесса задаёт индикаторы, которые впоследствии учитываются при анализе показателей. Базовые индикаторы задаются на конечном уровне матрицы, далее полученные данные интегрируются в итоговые показатели матрицы 0-го уровня. Следовательно, каждая матрица - неотъемлемая часть общего алгоритма внедрения структуры.

Пункт д) состоит в описании бизнес-процессов на основе инструментов IDEF0, «карты потока создания ценности», требований к процессам, а также в установлении критериев качества, формировании KРI - процессных и КРI - результирующих. Ключевые показатели эффективности (KPI) - показатели, поддающиеся количественному измерению и считающиеся наиболее важным для оценки эффективности деятельности фирмы, отдела или сотрудника. Они позволяют свести представления о том, как нужно функционировать, к единому пониманию, придать целевую направленность деятельности сотрудников, подразделений, рабочих групп. При создании системы KPI очень важно, чтобы используемые показатели были понятны всем сотрудникам, участвующим в этом процессе.

Выявленные несоответствия на уровне проектов требует их ликвидации. Упростить бизнес-процесс, сократить затраты потребуется полное описание бизнес-процесса на основе использования инструментов IDEF0 и «карта потока создания ценности».

Результатом описания процессов станет согласованный стандарт для каждой структурной единицы, а также структурного подразделения в целом. Подготовленный стандарт должен отражать все требования по реализации, результаты работы и критерии качества выполнения процесса. Стоит отметить, что важную роль в стандар- 
тизации работы играют наличие отклонений от деятельности процесса. На рис. 33 представлен пример сформированного описания бизнес-процесса.

Этап формирования предложенной системы оперативного управления, отраженный в пункте ж), отражает текущее состояние организации до анализа и корректировки процессов. Обязательным элементом организации системы управления является контроль выполнения бизнес-процессов по ключевым показателям эффективности. Мониторинг данных способствует выявлению отклонений от плановых показателей и причин возникновения несоответствий.

Пункт 3) состоит в формировании проектов улучшений, реализации и анализе полученных результатов. Этап подразумевает создание матрицы оперативного управления, что фактически представляет собой матрицу 2-го уровня - организация проектов улучшений на уровне линейного менеджмента. Выведенные данные показателей эффективности будут давать общее представление о достижении ключевых стратегических целей.

Построение методического подхода к управлению бизнес-процессами базируется на применении цикла постоянного совершенствования, описанного в разделе 4.3. Методический подход подразумевает поэтапное следование каждой из функций цикла PDCA, наглядно данная схема представлена на рис. 34. 


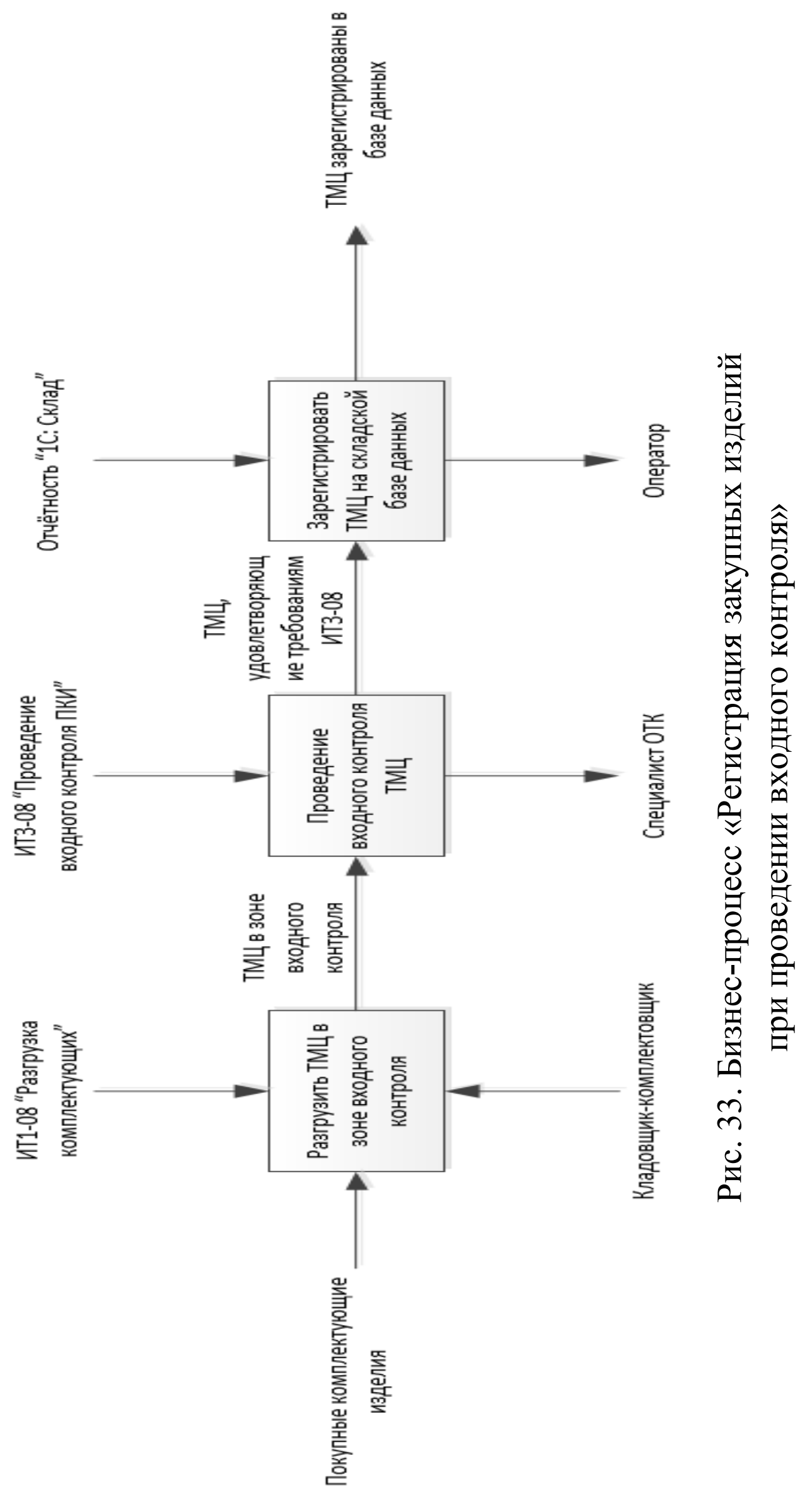




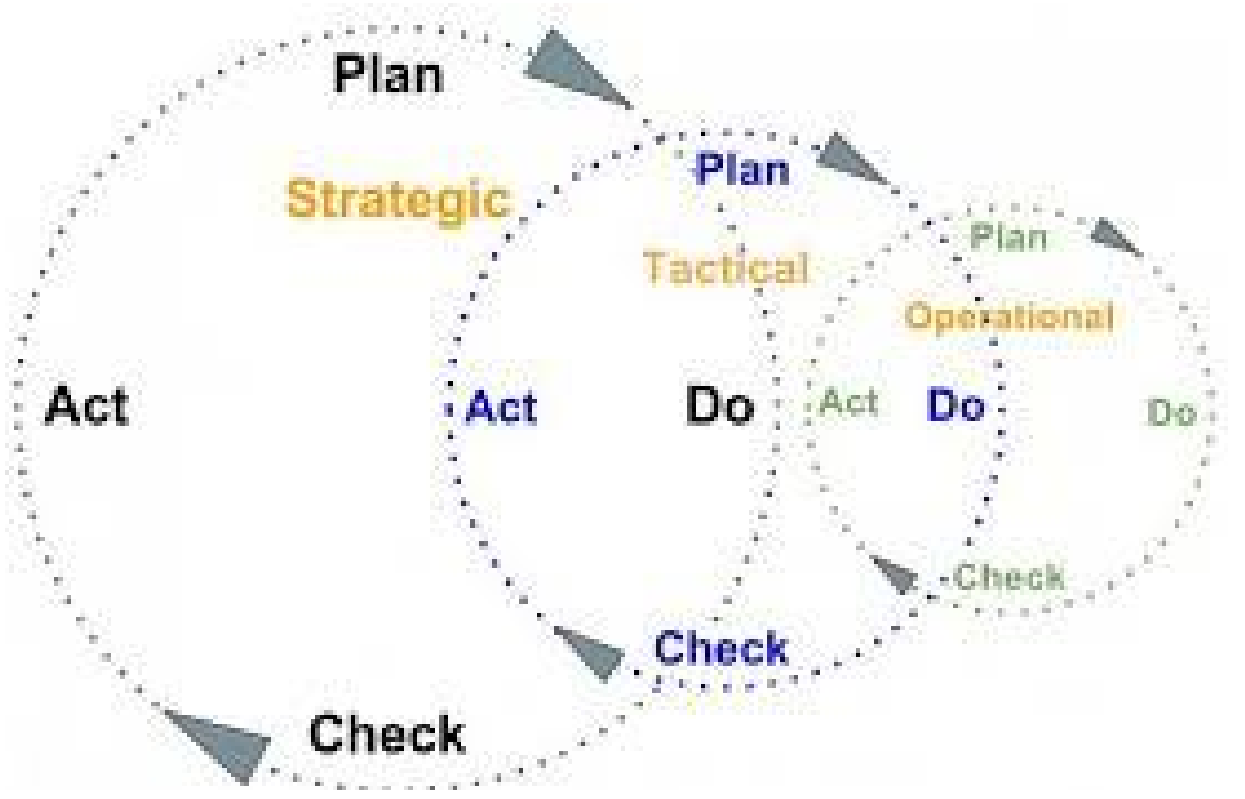

Рис. 34. Схема взаимодействия концепции Хосин-Канри и цикла PDCA

Структурная организация системы управления бизнес-процессами подразумевает их регулярный плановый контроль. В связи с этим важно правильно сформировать временные периоды для проверки показателей владельцем процесса. Каждая матрица обладает указанием на четкие временные рамки контроля задач и показателей. Данный процесс требуется для понимания необходимости корректировки состояния и функционирования организации в целом. Сформированные выводы позволят провести содержательный анализ для исправления несоответствий на оперативном уровне. Аналогичные процессы можно следует проводить на матрицах высшего уровня, формирующих результат итоговой работы по стратегическим целям.

Следовательно, методический подход не имеет определённого окончания цикла. Формальное завершение сводится к анализу фактических показателей и переходу к новому этапу планирования конкретных проектов улучшений, а в ряде случаев к применению актуальных стратегий и тактик. 


\section{2. Апробация методического обеспечения на предприятии}

Предложенное методическое обеспечение системы управления бизнес-процессами на предприятии может быть применено на предприятиях разного масштаба и профиля деятельности с адаптацией под структуру менеджмента, производственный процесс конкретного предприятия. Но для малых инновационных предприятий применение описанного инструментария может быть особенно продуктивно. Формализация и стандартизация бизнес-процессов позволят таким предприятиям успешно функционировать при их сравнительно небольших по численности управленческих структурах.

В качестве базы для реализации предложенного методического подхода к построению системы управления бизнес-процессами выступила компания ООО «МГ». В ходе совместной работы топменеджмента компании, руководителей подразделений был реализован ряд мероприятий согласно установленному алгоритму действий.

Сформировано долгосрочное стратегическое видение предприятия ООО «МГ»: ООО «МГ» занимает лидерские позиции в технологиях обработки листового стекла на рынке РФ с постоянным внедрением новых инновационных технологий и продуктов.

В качестве ключевых стратегических целей компании к 2022 году установлены целевые значения таких показателей, как чистая прибыль, выручка, рентабельность активов, доля покупки продукции компании среди общего числа продаж на ряде сегментов рынка, а также нулевое количество претензий со стороны клиентов, $100 \%$-я реализация бизнес-процессов на основе LEAN-инструментов, ежегодный вывод на рынок не менее двух новых типов продукции.

Каждая стратегическая цель имеет плановые показатели достижения целей. Фактические показатели также должны иметь важную 
составляющую в реализации подобной методики - они отражают текущее состояние действительности.

Следующим этапом реализации предложенного методического подхода является анализ внутренней и внешней среды предприятия для определения стратегий развития (определение технического состояния и варианты достижения целей). С этой целью используется инструмент SWOT-анализ, отраженный в табл. 13.

Таблица 13

SWOT-анализ деятельности предприятия OOO «МГ»

\begin{tabular}{|c|c|}
\hline Сильные стороны & Слабые стороны \\
\hline $\begin{array}{l}\text { - молодая, динамично развивающаяся } \\
\text { компания. Предприятие имеет новые под- } \\
\text { ходы в управлении бизнес-процессами, } \\
\text { широкомасштабное развитие рынков сбы- } \\
\text { та, выход на иностранные рынки сбыта; } \\
\text { - внедрение новых технических разрабо- } \\
\text { ток, инвестирование в научную состав- } \\
\text { ляющую деятельности предприятия, как } \\
\text { одну из центральных ветвей наукоёмкого } \\
\text { производства; } \\
\text { - основную массу персонала составляют } \\
\text { молодые специалисты, руководители от- } \\
\text { делов и подразделений - профессионалы } \\
\text { с огромным опытом работы. Это помогает } \\
\text { при обучении молодых специалистов, } \\
\text { формировании научной базы на основе } \\
\text { старых разработок совместно с новыми } \\
\text { инновационными идеями; } \\
\text { - широкий ассортимент выпускаемой про- } \\
\text { дукции, который создаёт общее благопри- } \\
\text { ятное представление о компании и вызы- } \\
\text { вает доверие клиентов }\end{array}$ & $\begin{array}{l}\text { - неупорядоченная структура предприятия. } \\
\text { В организационной структуре присутствует } \\
\text { ряд руководителей, чьё влияние на ряд под- } \\
\text { разделений пересекается, то есть отдельное } \\
\text { подразделение подчиняется нескольким ру- } \\
\text { ководителям согласно установленной иерар- } \\
\text { хии, что усложняет работы компании в це- } \\
\text { лом; } \\
\text { - несовершенный производственный про- } \\
\text { цесс. Имеются большие затраты, связанные } \\
\text { с системными потерями на производстве } \\
\text { и в иных подразделениях; } \\
\text { - проблема с персоналом: высокая текучесть } \\
\text { персонала в производственном секторе из-за } \\
\text { несистемного обучения, отсутствия адапта- } \\
\text { ционного периода пребывания сотрудника } \\
\text { на рабочем месте, а также из-за системных } \\
\text { потерь в производственном секторе: посто- } \\
\text { янные переработки, задержки заработной } \\
\text { платы }\end{array}$ \\
\hline
\end{tabular}


Окончание табл. 13

\begin{tabular}{|c|c|}
\hline Возможности & Угрозы \\
\hline $\begin{array}{l}\text { - персонал, готовый к изменениям. Спе- } \\
\text { циалисты готовы менять и совершенство- } \\
\text { вать собственную деятельность. Данные } \\
\text { явления благоприятны для делового кли- } \\
\text { мата предприятия; } \\
\text { - широкий спектр продуктов. Предпри- } \\
\text { ятие заинтересовано в расширении ассор- } \\
\text { тимента производимой продукции, добав- } \\
\text { лении наукоёмкого производства }\end{array}$ & $\begin{array}{l}\text { - Снижение качества продукции. При увели- } \\
\text { чении количества заказов, а также ускорении } \\
\text { срока сдачи готовой продукции утрачива- } \\
\text { ется качество выпускаемых товаров, что } \\
\text { приводит к отторжению клиента. Одним из } \\
\text { критериев качества продукции является тех- } \\
\text { ническое оснащение предприятия, а именно } \\
\text { циклический уход за оборудованием, за- } \\
\text { купка нового современного оборудования } \\
\text { и повышение квалификации персонала; } \\
\text { - конкурентоспособность. Российский ры- } \\
\text { нок наполнен средними компаниями, оказы- } \\
\text { вающими похожие услуги, как и «МГ». } \\
\text { В связи с этим, конкуренция возрастает, } \\
\text { в особенности на мелких и средних объек- } \\
\text { тах, что приводит к сезонной недозагрузке } \\
\text { производства и неравномерности планиро- } \\
\text { вания }\end{array}$ \\
\hline
\end{tabular}

В ходе анализа было выявлено, что предприятие занимает лидирующие позиции на рынке Российской Федерации и стран СНГ именно по применяемым технологиям и наличию инновационных видов продукции. Сегмент рынка, в котором предприятие имеет большие возможности - рынок крупных объектов строительства с большим объёмом поставляемой продукции. В тоже время, компания испытывает ряд трудностей с формированием организационной структуры и созданием эффективной рабочей среды, включающей постоянный мониторинг достижения ключевых показателей, эффективный контроль качества выпускаемой продукции и соответствие бизнес-процессов стандартам менеджмента качества компании. Данные показатели в длительном временном периоде могут способствовать ухудшению конкурентных позиций компании.

Следующим этапом внедрения методического подхода является формализация данных в формате концепции Хосин-Канри. Страте- 
гическое видение предприятия установлено в центре, и на каждом из уровней сохраняет своё положение в матрице и оказывает влияние на владельца процесса, а также на достижение целевых показателей. Полученные материалы структурированы с помощью инструмента $\mathrm{X-матрица} \mathrm{для} \mathrm{уровня:}$

- генерального директора (см. прил. А);

- заместителей генерального директора (см. прил. Б);

- руководителей функциональных подразделений (см. прил. В).

Каждый пункт матрицы, будь то годовые цели, стратегии, тактики имею собственный коэффициент влияния на общее видение компании и ключевые стратегические цели. Повышение данного коэффициента означает, что стратегия зависит от большего количества показателей.

Наиболее определённое состояние, когда отдельная стратегия или тактика зависит от конкретного показателя. В связи с этим о выполнении данного элемента можно судить по отклонениям от плановых значений конкретно выделенного показателя эффективности.

Данный инструмент позволяет менеджеру наиболее ясно оценивать ситуацию по реализации конкретных проектов и их влияние на видение предприятия и ключевые стратегические цели.

Для тактик задаются результирующие показатели эффективности (KРІ-результирующие), которые в свою очередь демонстрируют текущее состояние предприятия в целом. При наличии отклонений и дефектов, менеджеру необходимо принять решение об изменении текущего состояния. Инструменты, позволяющие качественно провести анализ процесса, наиболее полно отражают картину и коренную причину появления дефекта. Важно описать процесс от момента входных данных до выхода к конечному потребителю.

При выявлении отклонений и способов их устранения годовые цели, отражённые в Х-матрице, декомпозируются до конкретных 
проектов. На конечной стадии мониторинг показателей проектов проходит по 2 факторам: процессные KPI и результирующие KPI. Результирующие KРI отражают конкретный результат выполнения проекта, а процессные KPI - сопутствующие показатели, полученные по достижению результата. Матрицы 0-го уровня и 1-го уровня в графе мониторинг отражают исключительно результирующие КРI, в то время как матрица 2-го уровня имеет как процессные, так и результирующие KРI. Следующим ключевым этапом предложенной методики практического внедрения концепции управления качеством будет реализация проектов улучшений для достижения идеального состояния и ключевых стратегических целей.

Стоит сделать промежуточные выводы о том, что при формировании матриц мы столкнулись с одной из проблем внедрения концепции - отсутствие вовлеченности персонала в проведении мероприятий по совершенствованию производственного процесса и разделении ценностей компании. Результаты взаимодействия руководителей высшего и среднего менеджмента по формированию матриц отражены на рис. 35.

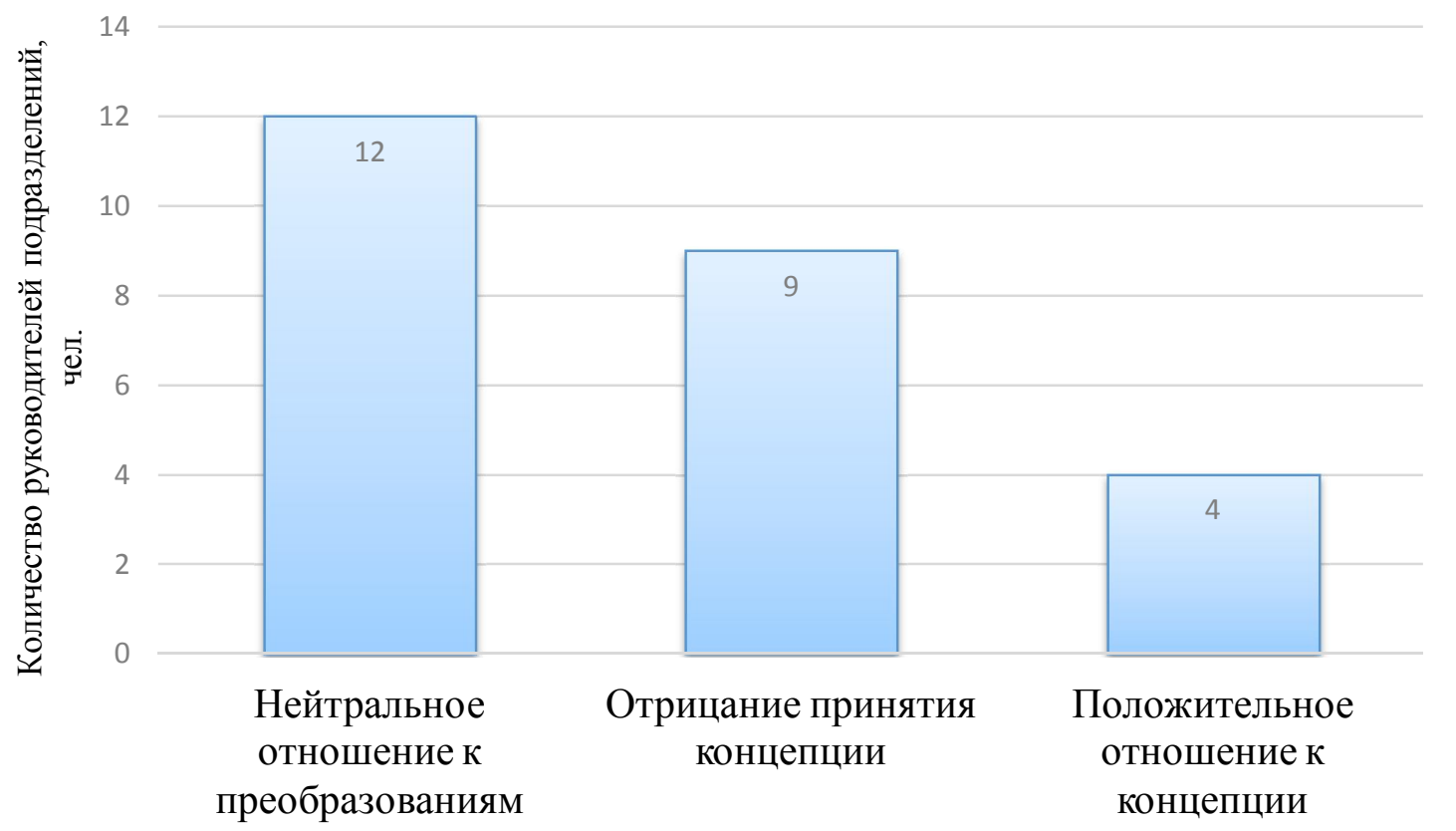

Рис. 35. Вовлеченность персонала предприятия в процессы внедрения концепции 
Следующим этапом предложенного методического подхода идёт мониторинг полученных показателей и выявления отклонений в функционировании бизнес-процессов на предприятии. Данные пункты позволят доказать эффективность системы на реальных примерах. Ведь процессы, которые выходят за рамки допустимых отклонений, оказывают влияние на общее состояние компании и ценностей, а выявленные дефекты приводят к нестабильности системы.

Произведем описание процессов в области функционирования службы качества, то есть распишем процессы со стороны владельцев процесса, входных и выходных данных, а также КРІ-результирующих и КРІ-процессных. Полученные данные позволят сделать выводы о мониторинге процессов и выявлении дефектов. За основу возьмём функционирование службы качества на предприятии. Данные будут отражены в табл. 14.

В течение отчётного периода был проведён анализ бизнес-процессов, на соответствие плановым показателям. Временной период мониторинга составлял десять недель. При этом показатели фиксировались каждую неделю опытными группами, которые участвовали в данных процессах. По истечении времени показатели проведения входного составляли 93\% от плановых, где 7\% материалов - брак по вине поставщика. Показатели проверки технологических дисциплин, а именно КРІ-результирующий выполнения технологических дисциплин в ходе проведения пооперационного контроля составлял 70\%.

В табл. 15 указаны статистические данные проектной группы по соответствующим отклонениям, а также рассчитана доля брака выпущенной продукции.

Для того чтобы выявить возникновение отклонений при выполнении данной операции «термообработка стекла», необходимо описание бизнес-процесса. На рис. 36 предоставлено описание технологического процесса «Проведение пооперационного контроля технологической дисциплины термообработки стекла». 


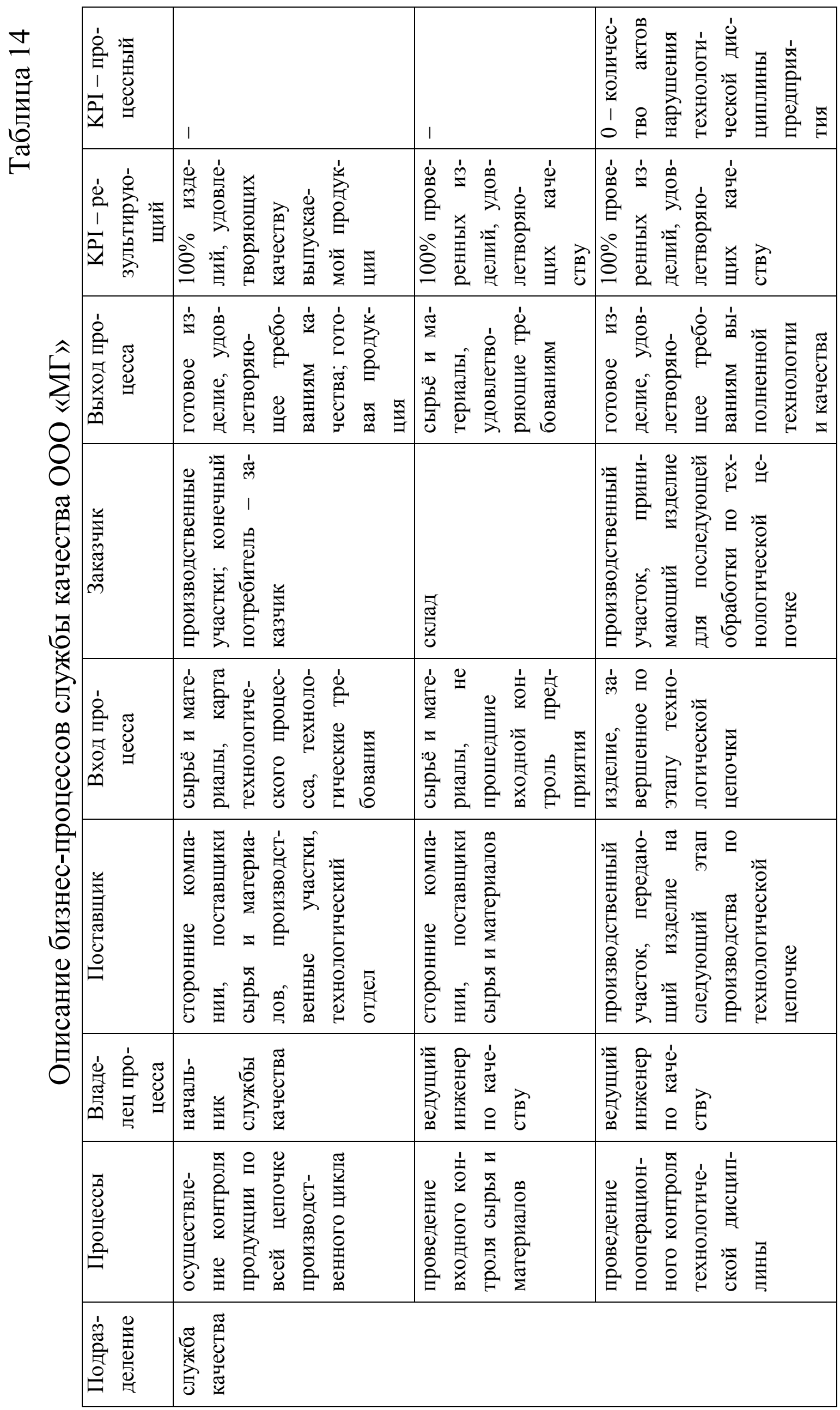


Данные о проведении пооперационного контроля соответствия технологической дисциплины на операции «термообработка стекла»

\begin{tabular}{|c|c|c|c|}
\hline Неделя & $\begin{array}{c}\text { Проверено } \\
\text { изделий, }\end{array}{ }^{2}$ & $\begin{array}{c}\text { Изделия, не прошедшие про- } \\
\text { верку качества по приёмке } \\
\text { на производственном участке } \\
\text { в среднем на смену, м }\end{array}$ & $\begin{array}{c}\text { Доля бракованной } \\
\text { продукции в среднем } \\
\text { на смену, \% }\end{array}$ \\
\hline 1 & 800 & 0,00 & 0,00 \\
\hline 2 & 630 & 31,25 & 4,96 \\
\hline 3 & 736 & 72,75 & 9,88 \\
\hline 4 & 748 & 64,25 & 8,59 \\
\hline 5 & 808 & 63,25 & 7,83 \\
\hline 6 & 813 & 7,50 & 0,92 \\
\hline 7 & 832 & 5,75 & 0,69 \\
\hline 8 & 613 & 13,25 & 2,16 \\
\hline 9 & 705 & 17,75 & 2,52 \\
\hline 10 & 648 & 11,50 & 1,77 \\
\hline
\end{tabular}

Согласно описанию бизнес-процесса, а также информации от специалистов предприятия следует, что при оценке качества оформления документов не возникает отклонений, в то время как основные дефекты возникают при проверке качества самого изделия после технологической обработки.

В связи с этим проведем анализ коренной причины возникновения несоответствий при пропуске бракованных изделий по технологической цепочке. Для анализа воспользуемся инструментами менеджмента качества, такими как «Диаграмма Исикавы» и «Контрольные карты Шухарта».

Подробное рассмотрение ситуации позволило сделать вывод, что специалисты технического контроля осуществляют проверку только сырья на входном контроле. При пооперационном контроле специалисты оказывают консультационные услуги. Саму проверку технологической дисциплины осуществляет оператор станка после выполнения операции. С помощью диаграммы Исикавы, отражённой 
на рис. 37, были выявлены основные факторы, влияющие на появление дефектов после технологической операции.

С помощью данного инструмента можно сделать вывод, что важную роль в оценке качества продукции играет квалификация специалиста, а также установленный стандарт оценки. По данным предприятия, стандартизированный процесс оценки отсутствует, что приводит к появлению брака и его передаче на последующую ступень производственной цепочки. К тому же, согласно ГОСТ 111-2014 «Стекло листовое бесцветное», существуют дефекты, запрещающие эксплуатацию стекла, в то время как существует ряд дефектов, допускающих эксплуатацию стекла и не влияющих на её ключевые характеристики.

Данные виды дефектов могут быть расценены как запрещающие эксплуатацию, что может привести определению продукции в брак. 


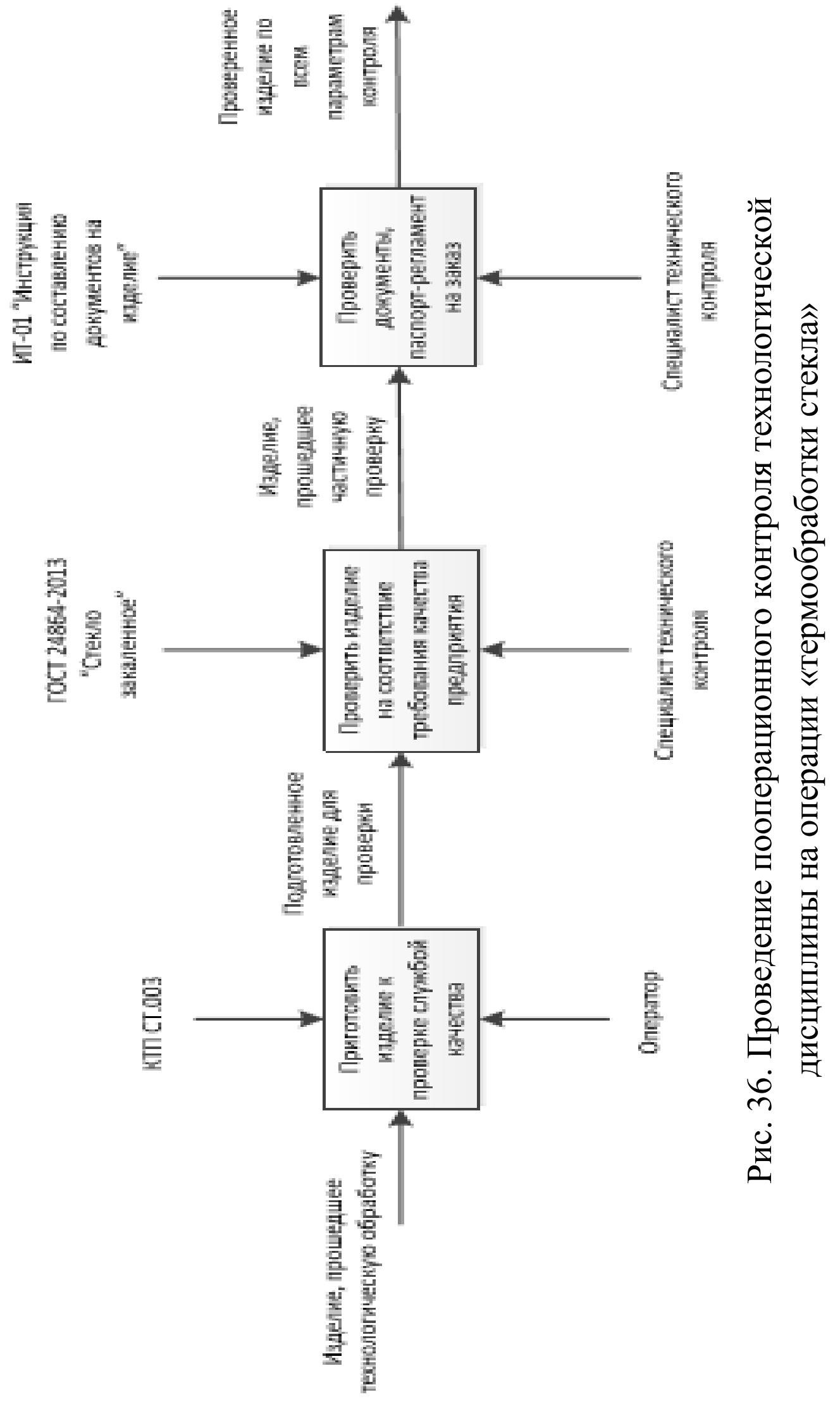




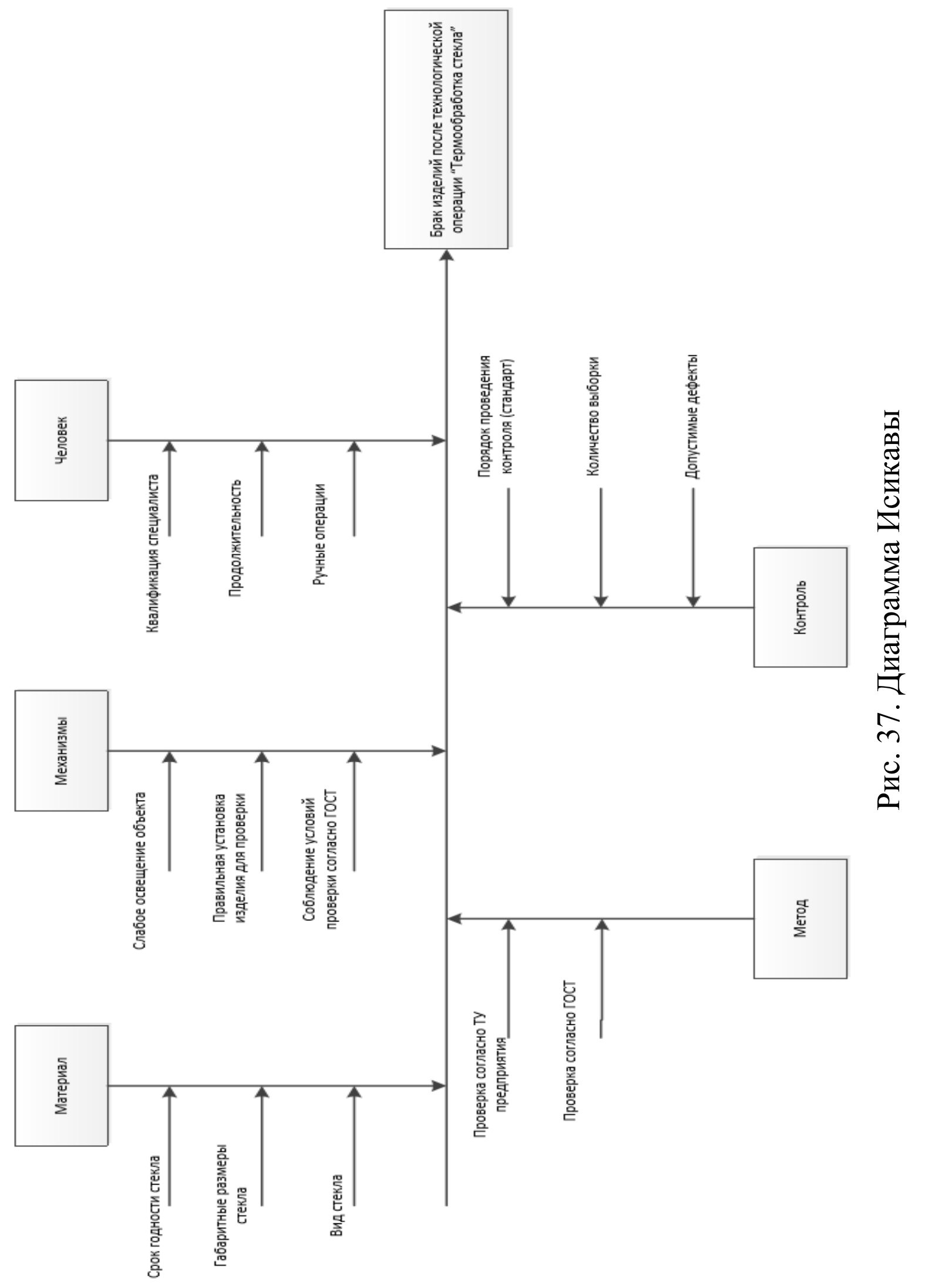


Рассмотрим данные о браке через инструмент «Контрольные карты Шухарта». В табл. 16 проведём необходимые расчёты для построения графика, который позволит выявить пределы допустимых отклонений процесса и элементы выхода за данные допустимые рамки. Области выхода позволят сделать вывод о работе системы.

В графе «Исполнитель» отражены данные об отклонениях на каждого оператора, т.е. сколько продукции было отправлено в брак по его решению. Графа «Среднее» отражает средний показатель брака по отдельной смене. Графа «Размах» отражает разницу между максимальным и минимальным значением показателя брака за смену.

Таблица 16

Данные о технологическом процессе «Термообработка стекла»

\begin{tabular}{|c|c|c|c|c|c|c|}
\hline \multirow{2}{*}{ Неделя } & \multicolumn{4}{|c|}{ Исполнитель } & \multirow{2}{*}{ Среднее $\bar{X}$} & \multirow{2}{*}{ Размах R } \\
\hline & $\mathrm{X}_{1}$ & $\mathrm{X}_{2}$ & $\mathrm{X}_{3}$ & $\mathrm{X}_{4}$ & & \\
\hline 1 & 0 & 0 & 0 & 0 & 0 & 0 \\
\hline 2 & 25 & 12 & 38 & 50 & 31,25 & 38 \\
\hline 3 & 86 & 78 & 28 & 99 & 72,75 & 71 \\
\hline 4 & 66 & 54 & 49 & 88 & 64,25 & 39 \\
\hline 5 & 58 & 69 & 73 & 53 & 63,25 & 20 \\
\hline 6 & 12 & 8 & 6 & 4 & 7,50 & 8 \\
\hline 7 & 11 & 5 & 4 & 3 & 5,75 & 8 \\
\hline 8 & 17 & 15 & 14 & 7 & 13,25 & 10 \\
\hline 9 & 21 & 19 & 18 & 13 & 17,75 & 8 \\
\hline 10 & 9 & 11 & 15 & 11 & 11,50 & 6 \\
\hline
\end{tabular}

Центральная линия контрольной карты будет соответствовать значению по формуле:

$$
\bar{R}=\frac{\sum R}{k}
$$

где $\mathrm{R}$ - размах значений, $\mathrm{k}$ - число недель, $\bar{R}$ - средний размах.

Центральная линия: $\mathrm{R}=20,8$. 
Верхний и нижний контрольные пределы соответствуют значениям по формулам

$$
\begin{aligned}
& U C L=D_{4} * \bar{R} ; \\
& L C L=D_{3} * \bar{R},
\end{aligned}
$$

где UCL - верхний контрольный предел, LCL - нижний контрольный предел, $\mathrm{D}_{4}$ и $\mathrm{D}_{3}-$ коэффициенты для вычислений линий контрольных карт, $\bar{R}-$ средний размах.

Следовательно,

$$
\begin{gathered}
U C L=2,282 * 20,8=47,47 \\
D C L=0 * 20,8=0 .
\end{gathered}
$$

По данным значениям строим контрольную карту Шухарта на рис. 38.

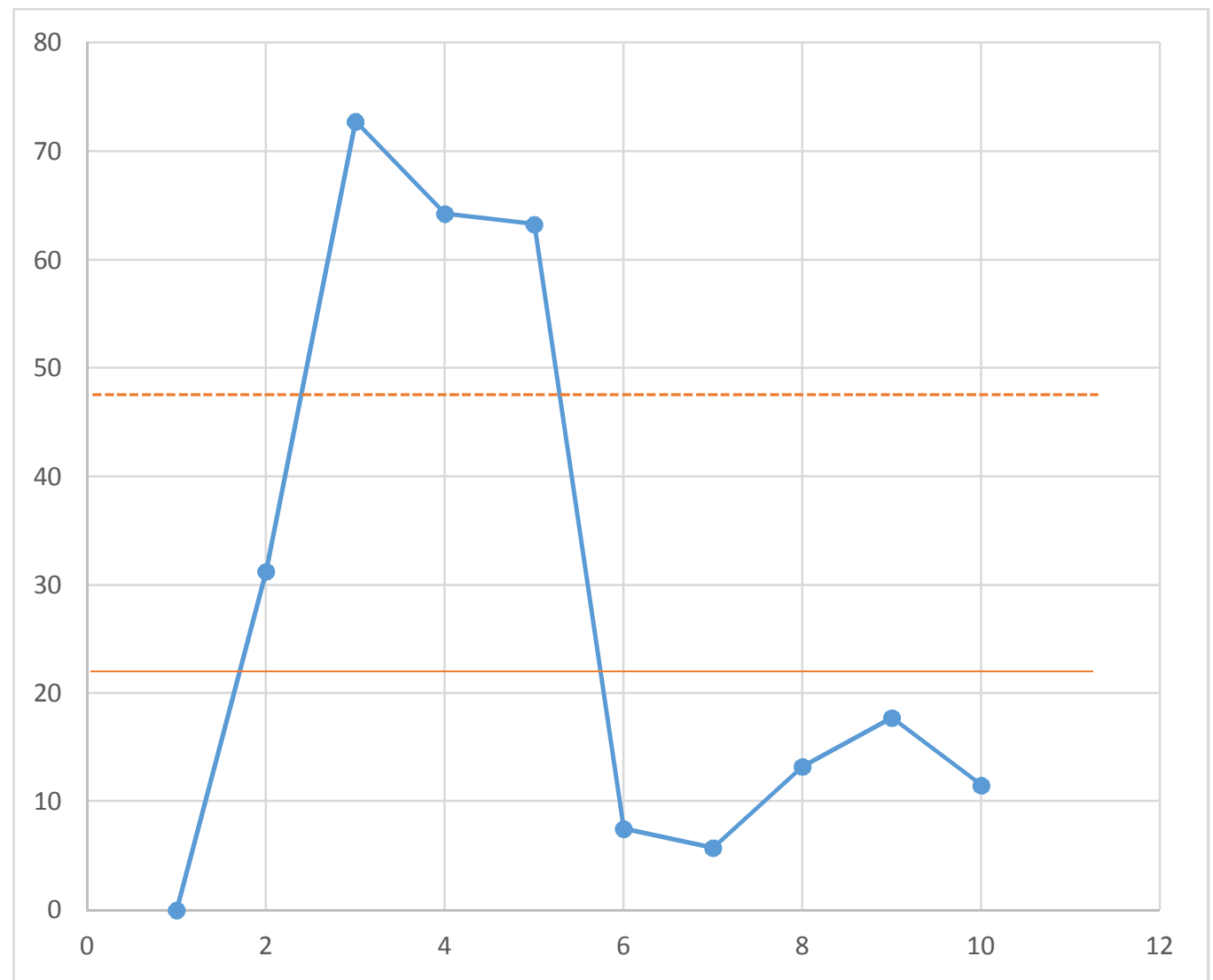

Рис. 38. Контрольная карта Шухарта 
По данным вычислениям выборка, выходящая за границы верхнего контрольного предела, сигнализирует о том, что данный процесс неуправляем и присутствует ряд дефектов, которые ухудшают работу системы.

Проанализировав полученные результаты в ходе анализа, можно сделать вывод, что с 3 по 5 неделю бригады отмечали большое количество брака. Нами был подробно рассмотрен процесс проверки изделий по качеству и сделан ряд выводов:

- большинство изделий, которые операторы станков отметили браком, проходили согласно требованиям ГОСТ как допустимые отклонения при эксплуатации;

- на предприятии отсутствует стандартизированный процесс проверки изделий по качеству. Операторы руководствуются теми данными, которые поступили из технологической службы. Структурированный описанный процесс проверки отсутствует на предприятии;

- группы бригад, которые вышли за пределы допустимых отклонений согласно контрольной карте Шухарта, не обладали достаточной квалификацией по оценке качества изделия. Опыт работы персонала бригады составлял меньше 8 месяцев.

Для полного завершения цикла предложенного методического подхода необходимо выделить ряд проектов улучшений, которые бы помогли устранить дефекты, описанные в работе. Показатели эффективности достижения поставленных задач будут связаны с итоговыми показателями в матрице 0-го уровня. В качестве проекта улучшения службе качества поручено внедрить проект «Стандартизация процессов». Согласно условиям матрицы каждый из показателей должен проверяться с определённой периодичностью, заданной владельцем процесса. В связи с этим, результаты проекта «Стандартизация процессов» будут продемонстрированы спустя контрольный 
период, который составляет один квартал. В прил. В показана матрица 2-го уровня с конкретными проектами для службы качества.

По истечении контрольного срока реализации проекта были выведены промежуточные результаты мероприятий «Стандартизация процессов».

В табл. 17 отображены актуальные показатели вывода продукции в брак спустя 3 месяца после начала реализации проекта.

Таблица 17

Данные о технологическом процессе «Термообработка стекла» после 3 месяцев реализации проекта улучшения

\begin{tabular}{|c|c|c|c|c|c|c|}
\hline \multirow{2}{*}{ Неделя } & \multicolumn{4}{|c|}{ Специалисты } & \multirow{2}{*}{ Среднее $\bar{X}$} & \multirow{2}{*}{$\begin{array}{c}\text { Размах } \\
\text { R }\end{array}$} \\
\hline & $\mathrm{X}_{1}$ & $\mathrm{X}_{2}$ & $\mathrm{X}_{3}$ & $\mathrm{X}_{4}$ & & \\
\hline 1 & 0 & 2 & 0 & 3 & 1,25 & 3 \\
\hline 2 & 21 & 13 & 33 & 39 & 26,50 & 26 \\
\hline 3 & 59 & 63 & 7 & 78 & 51,75 & 71 \\
\hline 4 & 48 & 46 & 38 & 73 & 51,25 & 35 \\
\hline 5 & 37 & 48 & 65 & 54 & 51,00 & 28 \\
\hline 6 & 3 & 7 & 7 & 6 & 5,75 & 4 \\
\hline 7 & 10 & 7 & 1 & 7 & 6,25 & 9 \\
\hline 8 & 11 & 16 & 10 & 5 & 10,50 & 11 \\
\hline 9 & 18 & 19 & 16 & 10 & 15,75 & 9 \\
\hline 10 & 7 & 9 & 14 & 10 & 10,00 & 7 \\
\hline
\end{tabular}

Проведём расчёт «контрольной карты Шухарта», а затем сравнение состояния «до» и «после». Согласно приведенной выше формуле, центральная линия контрольной карты будет равна 20,3.

Следовательно, верхний и нижний контрольные пределы будут равны

$$
\begin{gathered}
U C L=2,282 * 20,3=46,32 \\
D C L=0 * 20,3=0 .
\end{gathered}
$$


Построим графики «контрольных карт Шухарта» до внедрений и после, изображённых соответственно на рис. 39 и 40.

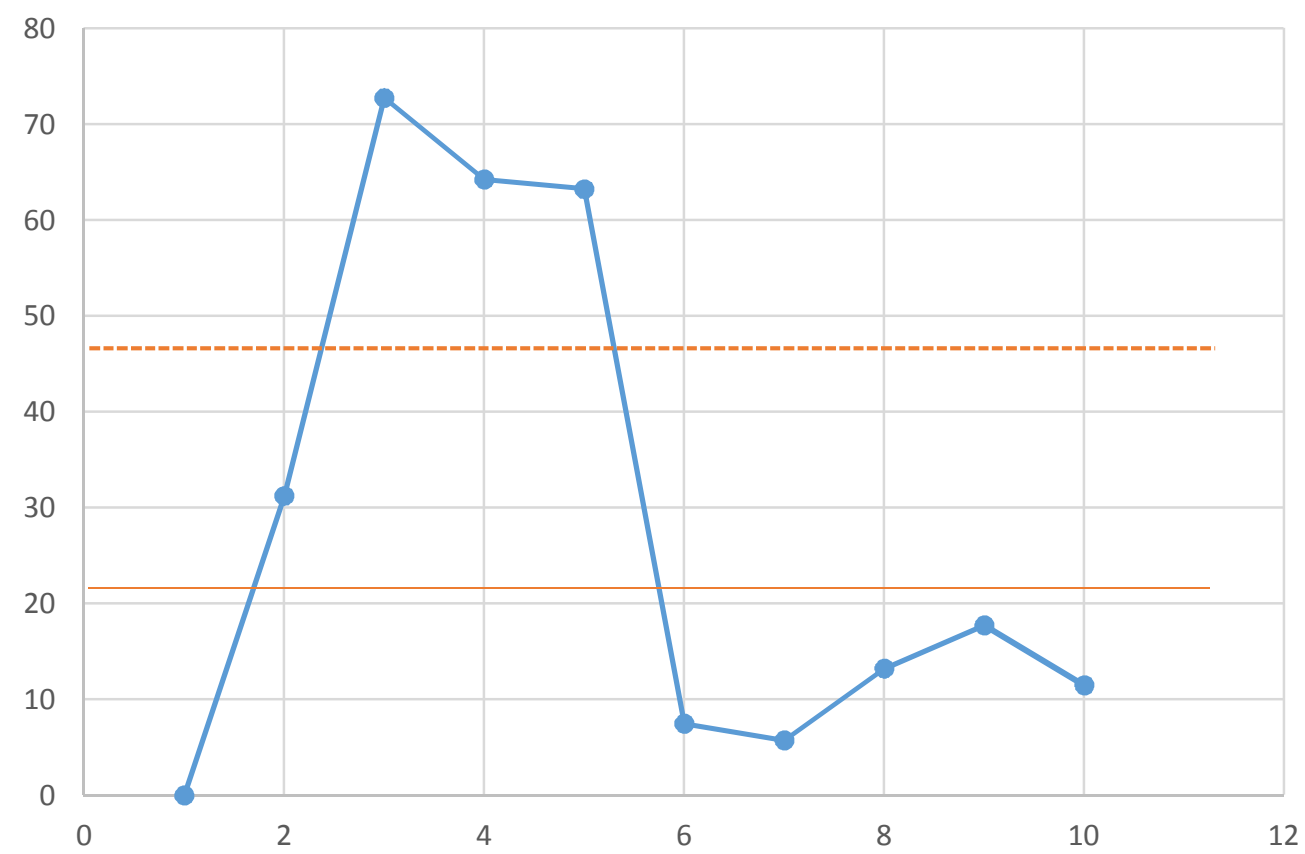

Рис. 39. «Контрольная карта Шухарта» до изменений

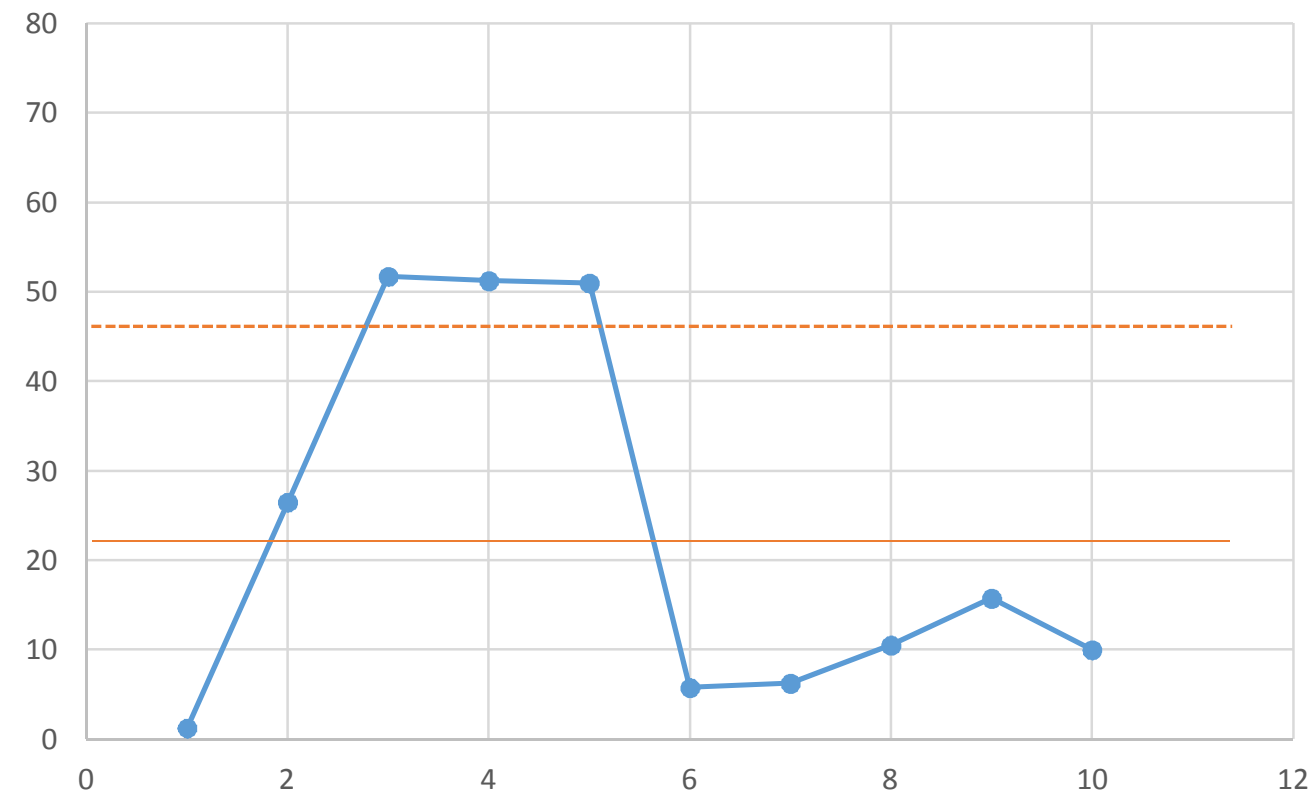

Рис. 40. «Контрольная карта Шухарта» после изменений 
По графикам мы можем видеть тенденцию, что процесс стал более управляемым, показатели, выходящие за границы верхнего контрольного предела, приближаются в допустимую область. Данные свидетельствуют о том, что на предприятии выработали общие правила проведения контроля.

Для построения стандарта было проведено обучение операторов, выведено на регулярную основу развитие квалификации персонала. Основным достижением можно считать упрощение работы операторов, связанное визуализацией процессов.

По итогам апробации предложенной системы управления бизнес-процессами можно сделать вывод о ее практической применимости и эффективности. На предприятии полученные результаты нашли одобрение руководства предприятия. Реализация предложений затронула подразделения производства, коммерческого отдела, отдела управления персоналом. Результаты позволили предприятию выявить проблемы организации системы менеджмента, способствовали вовлечению персонала компании в достижение амбициозных целей компании, а также сократили издержки на выполнение производственных процессов с одновременным повышением качества продукции и бизнес-процессов, реализуемых на предприятии. 


\section{ЗАКЛЮЧЕНИЕ}

Многие новейшие направления научно-технического прогресса в частном секторе развиваются именно за счет малого бизнеса. Инновационный бизнес одновременно является уникальным и сложным, перспективным и высоко рискованным. Процветание этого сектора малого предпринимательства будет способствовать эффективному и стабильному экономическому развитию нашей страны в будущем.

Результаты проведенного исследования позволяют сформулировать выводы и предложения, использование которых на практике может способствовать формированию и эффективному функционированию малого инновационного предприятия.

В России над теоретическими аспектами инноваций трудится достаточно много авторов. Тем не менее, они во многом цитируют западных ученых. Нами дана попытка систематизации базовых понятий и некоторых принципов в инновационной сфере. Систематизирована и дополнена классификация форм инновационных предприятий с выделением понятия «инновационно-внедренческие предприятия», занимающиеся не столько разработкой, сколько распространением существующих инноваций.

В монографии выделены и проработаны элементы организационно-экономического механизма создания малого инновационного предприятия внедренческой направленности, смоделированы бизнес-процессы, обеспечивающие начало его деятельности, проведена апробация организационно-экономического обеспечения создания малого инновационного предприятия. Детальная проработка организационно-экономического механизма и бизнес-процессов, связанных с созданием таких предприятий, а также апробация разработок осуществлена на примере малого предприятия в сфере стоматологии. 
В работе проанализирован рынок стоматологических услуг, показана необходимость развития инноваций в этой сфере. Выбрана стартовая инновационная идея, на базе которой может быть создано малое инновационное предприятие внедренческой направленности в стоматологии. В качестве такой идеи предложено применение плазмокерамики, до сих пор использовавшейся в военной сфере и производстве огнеупорных изделий. Как показывают исследования, этот материал может быть прекрасным заменителем циркония и других материалов, применяющихся для изготовления зубных протезов, превосходящим их по ряду показателей и несомненно более выигрышным по цене.

Проведенное маркетинговое исследование показало, что проект по внедрению плазмокерамики в стоматологию имеет все шансы на успех, что послужит стартом для эффективного развития создаваемого инновационно-внедренческого предприятия. Предложенный механизм формирования предприятия может быть применен и в других сферах деятельности.

Эффективное функционирование малого инновационного предприятия требует эффективного менеджмента. Основу системы менеджмента предприятия может заложить концепция Total Quality Management (всеобщее управление качеством - TQM). Основная направленность концепции состоит в обеспечении высокого качества всех бизнес-процессов, осуществляемых на предприятии, а как следствие - высокого качества результатов деятельности - производимых продукции и услуг.

В работе исследованы основные теоретические аспекты концепции всеобщего управления качеством TQM, рассмотрены преимущества и недостатки ее использования. Важный момент изучения данной проблемы заключается в применении системы управления качеством в общей структуре менеджмента компания, в частности, в использовании принципов и инструментов ТQМ при формировании бизнес-процессов компании. 
Концепция TQM, как и отдельные инструменты управления качеством, нашли применение на российском рынке. Однако широкое применение TQM затруднено и часто не приносит желаемого результата. Во многом это связано, на наш взгляд, с тем, что для повышения эффективности результатов необходимо системное применение инструментов и полное системное взаимодействие.

Особенностью разработанного методического обеспечения системы управления бизнес-процессами на малом инновационном предприятии на основе концепции TQM является интеграция специфических инструментов планирования, организации и анализа отклонений в единую систему. Логика предложенного механизма состоит в декомпозиции долгосрочных стратегических целей до конкретных проектов улучшений по совершенствованию бизнес-процессов и ликвидации возникающих отклонений в производственном процессе и реализации управленческих функций.

Инструменты, предложенные для интегрирования в методическое обеспечение, реализуют выполнение отдельных задач в системе управления бизнес-процессами, но работают на единый результат. Так, инструмент Хосин-Канри применяется для планирования, декомпозиции целей, а также структурного мониторинга реализуемых проектов улучшений. Моделирование бизнес-процессов осуществляется на основе использования инструментов IDEF0 и «карты потока создания ценности»

Диаграмма Исикавы и контрольные карты Шухарта необходимы для анализа отклонений бизнес-процессов и выявления коренной причины несоответствий, а заданные показатели КРI способствуют полному мониторингу достижения стратегических и декомпозированных годовых целей. Обеспечение возобновляемости и цикличности процесса непрерывных улучшений основано на поэтапном следовании каждой из функций цикла PDCA. 
Реализация предложенного подхода к управлению бизнес-процессами должна носить системный характер. Любой уровень менеджмента, каждое подразделение компании должно понимать ключевые ценности предприятия и иметь стратегическое видение. Цели подразделений должны быть согласованы с достижением общего итогового результата. И предлагаемая система инструментов позволяет решить эти задачи.

Необходимым условием применения предлагаемой методики является вовлеченность каждого сотрудника в процессы преобразований. Хосин-канри обеспечивает декомпозицию целей и передачу подцелей и соответствующих показателей на оперативный уровень компании. Именно так каждый сотрудник предприятия сможет ощутить собственный вклад в развитие компании.

Особенно это важно для малых предприятий, где вклад каждого работника в общий результат более весом, чем в крупных компаниях. Тем более важна такая консолидация целевых установок деятельности и синхронизация усилий в инновационных компаниях, постоянно реализующих те или иные нововведения.

Разработка действенных механизмов вовлечения персонала важнейший элемент внедрения методического обеспечения системы управления бизнес-процессами на малом инновационном предприятии. 


\section{БИБЛИОГРАФИЧЕСКИЙ СПИСОК}

1. Глобальный инновационный индекс - 2016 / В.В. Власова, Л.М. Гохберг, Т.Е. Кузнецова, В.А. Рудь // Институт статистических исследований и экономики знаний НИУ ВШЭ. Москва, 2016.

2. Российский статистический ежегодник. 2017 / Стат. сб. [Мск.]. URL: http://www.gks.ru/wps/wcm/connect/rosstat_main/rosstat/ ru/statistics/publications/catalog/doc_1135087342078 (дата обращения: 02.09.2019).

3. Белл Д. Грядущее постиндустриальное общество: Опыт социального прогнозирования: учебник / Д. Белл. - Пер. с англ. Иноземцев В.Л. (ред. и вступ. ст.). - М. : Academia, 1999.

4. Тоффлер Э. Революционное богатство: учебник / Э. Тоффлер, Х.Тоффлер. - М.: АСТ, 2007.

5. Фукуяма Ф. Наше постчеловеческое будущее: Последствия биотехнологической революции: учебник / Ф. Фукуяма; Пер. с англ. МБ. Левина. - М.: ООО Издательство АСТ: ОАО ЛЮКС, 2004.

6. Деминг Э. Выход из кризиса: Новая парадигма управления людьми, системами и процессами. - М.: Альпина Бизнес Букс, 2007.

7. Яголковский С. Р. Психология инноваций: подходы, модели, процессы: учебник / С. Р. Яголковский. - М.: НИУ ВШЭ, 2011.272 c. - ISBN 978-5-7598-0771-1.

8. Агарков С. А. Инновационный менеджмент и государственная инновационная политик: учебное пособие/ С. А. Агарков, Е. С. Кузнецова, М. О. Грязнова; Федер. агентство по рыболовству, Мурм. гос. техн. ун-т. - М.: Акад. естествознания, 2011. - 143 с.

9. Медынский В.Г. Инновационный менеджмент: учебник / В.Г. Медынский. - М.: Инфра-М, 2005. - 293 с.

10. Гашко Д.В. Понятие инноваций в современной экономической теории // Вестник Ленинградского государственного университета им. А.С. Пушкина, - 2011. - № 1 (Том 6), Экономика. С. $15-24$. 
11. Руководство Осло. Рекомендации по сбору и анализу данных по инновациям. 3-е изд., совместная публикация ОЭСР и Евростата; пер. на рус. яз. - М.: ГУ «Центр исследований и статистики науки», 2006. URL: https://mgimo.ru/upload/docs_6/ ruk.oslo.pdf/ (дата обращения 02.09.2019).

12. Инновационный и проектный менеджмент: учебное пособие. - Ростов-на-Дону : Изд-во ЮФУ, 2014. - 181 с.

13. Ушаков Г.В. Инновационная деятельность малых предприятий: электронное учебное пособие / Г.В. Ушаков, А.Г. Ушаков. Кемерово : ГУ КузГТУ, 2014. - 132 с.

14. Сергеев В.А. Основы инновационного проектирования: учебное пособие / В. А. Сергеев, Е. В. Кипчарская, Д. К. Подымало; под ред. д-ра техн. наук В. А. Сергеева. Ульяновск: УлГТУ. 246 с.

15. Цветков А.Н. Менеджмент / А.Н. Цветков. - СПб.: Питер, 2009. - $176 \mathrm{c}$.

16. Организационные структуры «экономики знаний»: Сборник научных трудов / РАН. ИНИОН. Центр науч.-информ. исслед. по науке, образованию и технологиям; Отв. ред. Пястолов С.М. (Сер.: Методол. проблемы развития науки и техники) - М. : ИНИОН РАН, 2010. - $152 \mathrm{c}$.

17. О развитии малого и среднего предпринимательства в Российской Федерации : Федеральный закон № 209-Ф3: принят Гос. Думой 6 июля 2007, одобрен Советом Федерации 11 июля 2007 г. - URL: https://rg.ru/2007/07/31/biznes-doc.html (дата обращения 02.09.2019).

18. Сергеев В.А. Основы инновационного проектирования: учебное пособие / В.А. Сергеев, Е.В. Кипчарская, Д.К. Подымало. Ульяновск : УлГТУ, 2010.

19. Тычинский А.В. Управление инновационной деятельностью компаний: современные подходы, алгоритмы, опыт: учебное пособие / А.В. Тычинский. - Таганрог : ТРТУ, 2006. 
20. Асаул А.Н. Модернизация экономики на основе технологических инноваций: учебник / А.Н. Асаул, Б.М. Карпов, В.Б. Перевязкин, М.К. Старовойтов. СПб : АНО ИПЭВ, 2008. 606 с.

21. Примак Л.В. Международное объединение технологий и инноваций - кластерный подход / Л.В. Примак // Механизация строительства. - 2013. - № 11. - С. 55.

22. Рахматуллина Е.С. Решение задач управления строительным предприятием посредством нестандартных инновационных шагов / Е.С. Рахматуллина // Управление экономическими системами: электронный научный журнал. - 2010. - № 24. - С. 496-499.

23. Устинова Л.Н. Выявление условий рентабельности инновациионных проектов / Л.Н. Устинова // Финансовая аналитика: проблемы и решения. - 2013. - № 7. - С. 35-38.

24. Низамова А.Ш. Способы финансирования инновационной деятельности / Л.Р. Раимджанова, А.Ш. Низамова // Инновации в науке - 2013. - № 25. - С. 212-216.

25. Clausen Tommy H. Do subsidies have positive impacts on R\&D and innovation activities at the firm level? // Structural Change and Economic Dynamics, Elsevier, vol. 20(4), pages 239-253, December 2009.

26. Castellacci F. and Natera J. M. The dynamics of national innovation systems: A panel cointegration analysis of the coevolution between innovative capability and absorptive capacity // Research Policy, 42(3) : pages 579 - 594, 2013.

27. Cirillo V., Martinelli A., Nuvolari A. and Tranchero M. Only one way to skin a cat? National innovation systems in the xxi century. // Technical report, Institute of Economics, Scuola Superiore SantAnna, Pisa, Italy, 2016.

28. Реймер В.В. Зарубежный опыт государственной инновационной политики / В.В. Реймер // Дальневосточный аграрный вестник. -2013. - № 4 (28). - C. 70-75.

29. Merrill S., Levin R. and Myers M. Patent System for the 21st Century, Washington, DC: Committee on Intellectual Property Rights in the KnowledgeBased Economy // National Research Council, 2004. 
30. Youtie J. and Shapira P. Building an Innovation Hub: A Case Study of the Transformation of University Roles in Regional Technological and Economic Development // Research Policy, 37, 1188-1204, 2008.

31. National Academies: SBIR and the Phase III Challenge of Commercialization: Report of a Symposium. Washington DC: National Academies Press, 2007.

32. Presidents Council of Advisors on Science and Technology the National Nanotechnology Initiative at Five Years. Washington, DC: Government Printing Office, 2005.

33. Peter L. Singer. Federally Supported Innovations: 22 Examples of Major Technology Advances at Stem From Federal Research Support // Information Technology and Innovation Foundation, February, 2014.

34. Мировые новости от электронного издательства The World Only: Рейтинг инновационных экономик 2018. URL: https://theworldonly.org/rejting-innovatsionnyh-ekonomik-2018/ (дата обращения: 21.01.2019).

35. Веселовский М.Я. Организационно-экономические особенности развития и функционирования малого инновационного предпринимательства / М.Я. Веселовский, М.В. Старостина // МИР (Модернизация. Инновации. Развитие). - М. : ООО Издательский дом «Наука». - 2016. - № 4 (28). - С. 167-174.

36. Сакаро Г.А. Стимулирование инновационной деятельности в России / Г.А. Сакаро // Проблемы экономики и менеджмента. 2016, - № 5 (57). - C. 45-57.

37. О порядке предоставления субсидий субъектам инновационной деятельности малого и среднего предпринимательства: Постановление Правительства Ростовской области от 31 мая 2017 № 398 (Действующая редакция с изменениями от 28 декабря 2017). URL: pravo.donland.ru/doc/view/id/Постановление_ 398_05062017_6016/ (дата обращения: 02.09.2019). 
38. Национальный доклад об инновациях в России - 2017 / Министерство экономического развития России, Открытое правительство, PBK, 2017. URL: https://www.rvc.ru/upload/ iblock/c64/RVK_innovation_2017.pdf (дата обращения: 02.09.2019).

39. Перечень - список технопарков России 2019 год. Индустриальные парки и технопарки России. URL: https://russiaindustrialpark.ru/tehnopark_catalog_perecheny_spisok_russia (дата обращения: 02.09.2019).

40. Государственная поддержка бизнес- инкубирования: международный опыт / Информационная поддержка Национальной Палаты Предпринимателей Республики Казахстан [Кз.], 2014. URL: http://atameken.kz/uploads/content/files/ (дата обращения: 02.09.2019).

41. Кашинова Е. А. Бенчмаркинг национальных инновационных систем: Европейский инновационный индекс / Е.А Кашинова // ИСИЭЗ НИУ ВШЭ, 2018. URL: https://issek.hse.ru/ news/245202161.html (дата обращения: 02.09.2019).

42. Анализ рынка стоматологий 2018 по данным маркетингового агентства «Альтера-Инвест». URL: https://alterainvest.ru/rus/ blogi/analiz-rynka-stomatologiy-2018/ (дата обращения: 02.09.2019).

43. Анализ рынка стоматологических имплантов в России. URL: https://www.prnews.ru/topic/analiz-rynka-stomatologiceskihimplantov-v-rossii-2 (дата обращения: 02.09.2019).

44. Вершинина М. В. Низкотехнологичные отрасли: поиск инновационной стратегии развития / М. В. Вершинина // Инновации. 2010. № 8. C. 67-72. URL: https://cyberleninka.ru/article/n/ nizkotehnologichnye-otrasli-poisk-innovatsionnoy-strategii-razvitiya (дата обращения: 23.05.2019).

45. Корнилова О.А. Источники финансирования малого и среднего предпринимательства: банковское кредитование / О.А. Корнилова // Символ науки. - 2016. - № 5-1. - С. 137-139. - URL: https://cyberleninka.ru/article/n/istochniki-finansirovaniya-malogo-i- 
srednego-predprinimatelstva-bankovskoe-kreditovanie (дата обращения: 02.09.2019).

46. Шушакова В.С. Стратегический риск-менеджмент как эффективный способ управления организацией / В.С. Шушакова // European science. - 2016. - № 2. - C. 44-45.

47. Попов А.В. Современные аспекты управления рисками инновационного проекта / А.В. Попов, А.Н. Плотников, Д.А Плотников // Финансовая аналитика: проблемы и решения. - 2015. № 28 (262). - С. 47-59.

48. Дармилова Ж.Д. Особенности риск-менеджмента в инновационной деятельности: региональный аспект / Ж.Д. Дармилова, Ю.С Колесников // JER. - 2015. - № 1. - С. 91-104. URL : https://cyberleninka.ru/article/n/osobennosti-risk-menedzhmenta-vinnovatsionnoy-deyatelnosti-regionalnyy-aspekt (дата обращения: 02.09.2019).

49. ЦНИИС стоматологии. Официальный сайт. URL: http://www.cniis.ru/ (дата обращения: 02.09.2019).

50. Абалкин Л.И. Экономическая история СССР / Л.И. Абалкин. М. : ИНФРА-М, 2007. - 496 с.

51. ЕфремоваТ.Ф. Современный толковый словарь русского языка / Т.Ф. Ефремова. - Санкт-Петербург: Астрель, 2006. - 933 с.

52. Кузнецова С.А. Большой толковый словарь русского языка / С.А. Кузнецова - Санкт-Петербург: Норинт, 1998. - 1534 с.

53. Прохоров А.М. Советский энциклопедический словарь / А.М. Прохоров - М.: Большая Российская энциклопедия, 1989. $1632 \mathrm{c}$.

54. ГОСТ 15467-79. Управление качеством продукции. Основные термины и определения // Электронный фонд правовой и нормативно-технической документации. URL: http://docs.cntd.ru/ document/gost-15467-79 (дата обращения: 02.09.2019).

55. ГОСТ Р ИСО 9000-2001. Системы менеджмента качества. Основные положения и словарь от 31.08.2001 г. // Электронный 
фонд правовой и нормативно-технической документации. URL: http://docs.cntd.ru/document/1200015260 (дата обращения: 02.09.2019)

56. Джуран Дж. Справочник по контролю качества / Дж. Джуран. - McGraw-Hill, 1999. 1730 c. ISBN: 0-07-034003-X.

57. Глудкин О.П. Всеобщее управление качеством: учебник / О.П. Глудкин, Н.М Горбунов, А.И. Гуров. - М.: Горячая линия Телеком, 2001. $-600 \mathrm{c}$.

58. ГОСТ Р ИСО 9000-2015. Системы менеджмента качества. Основные положения и словарь от 01.11.2015 г. // Электронный фонд правовой и нормативно-технической документации. URL: http://docs.cntd.ru/document/1200124393 (дата обращения: 02.09.2019)

59. Лапидус В.А. Всеобщее качество (TQM) в российских компаниях / В.А. Лапидус - М : Типография «Новости», 2008.

60. Зедгинидзе И.Г. Всеобщее управление качеством ТQM / И.Г. Зедгинидзе. - Тбилиси: Технический университет - Центр информатизации, 2005. $-82 \mathrm{c}$.

61. Мишин В.М. Управление качеством: учебник / В.М. Мишин. - М. : ЮНИТИ-ДАНА, 2005.

62. Исикава К. Японские методы управления качеством / К. Исикава. - М.: Экономика, 1988. - с. 215.

63. Вумек Дж. П., Джонс Д. Т. Бережлвиое производство: Как избавиться от потерь и добиться процветания вашей компании / Дж. П. Вумек, Д. Т. Джонс. - М. : Альпина Бизнес Букс, 2005.

64. Васин С.Г. Управление качеством. Всеобщий подход: учебник для бакалавриата и магистратуры / С.Г. Васин. - М.: Юрайт, 2015.

65. Shewhart W. Statistical Method from the Viewpoint of Quality Control. - N.Y.: Dover Publ., Inc., 1939 (reprint 1986). - 163 p.

66. Джеффри Л. Дао Toyota: 14 принципов менеджмента ведущей компании мира / Л. Джеффри - М.: Альпина Бизнес Букс, 2005.

67. Харрингтон Дж. Управление качеством в американских корпорациях / Дж. Харрингтон; пер. с англ. - М.: Экономика, 1990. $272 \mathrm{c}$. 
68. Деминг Э. Новая экономика / Э. Деминг. - М. : Эксмо, 2006. $208 \mathrm{c}$.

69. Джордж С. Всеобщее управление качеством / С. Джордж, А. Ваймерских. - М. : Виктория плюс, 2002. - 256 с.

70. Кондо Ё. Хосин канри - один из подходов японского менеджмента качества / Ё. Кондо // Управление качеством. - 2018. № 12. - C. 26-36. - ISSN: 2074-9945.

71. Уилер Д. Статистическое управление процессами. Оптимизация бизнеса с использованием контрольных карт Шухарта / Д. Уилер, Д. Чамберс - М.: Альпина Паблишер, 2009. - 416 с.

72. Джексон Т. Хосин-Канри: как заставить стратегию работать / Т. Джексон - М.: Институт комплексных стратегических исследований, 2008. - 248 с.

73. Коваленко П.А. Х-матрица как инструмент развертывания стратегии компаний / П.А. Коваленко // Методы менеджмента качества. -2015 . - № 8.

74. Блауберг И. В. Системный подход в современной науке / И. В.Блауберг, В. Н. Садовский, Э. Г. Юдин - М. : Мысль, 1970.

75. ГОСТ Р 50779.42-49. Статистические методы. Контрольные карты Шухарта. // Электронный фонд правовой и нормативнотехнической документации. URL : http://docs.cntd.ru/document/gost-r50779-42-99 (дата обращения 02.09.2019). 


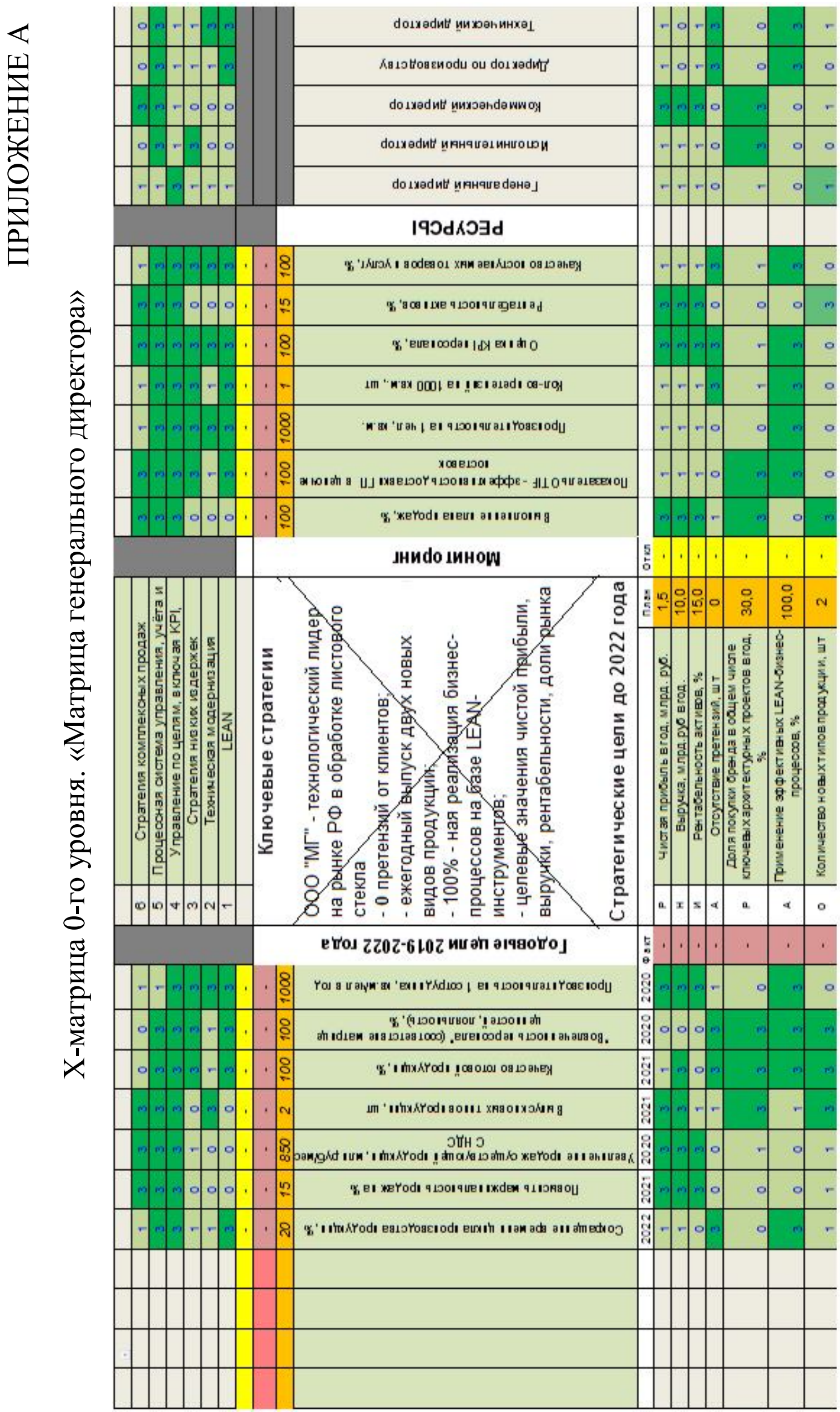




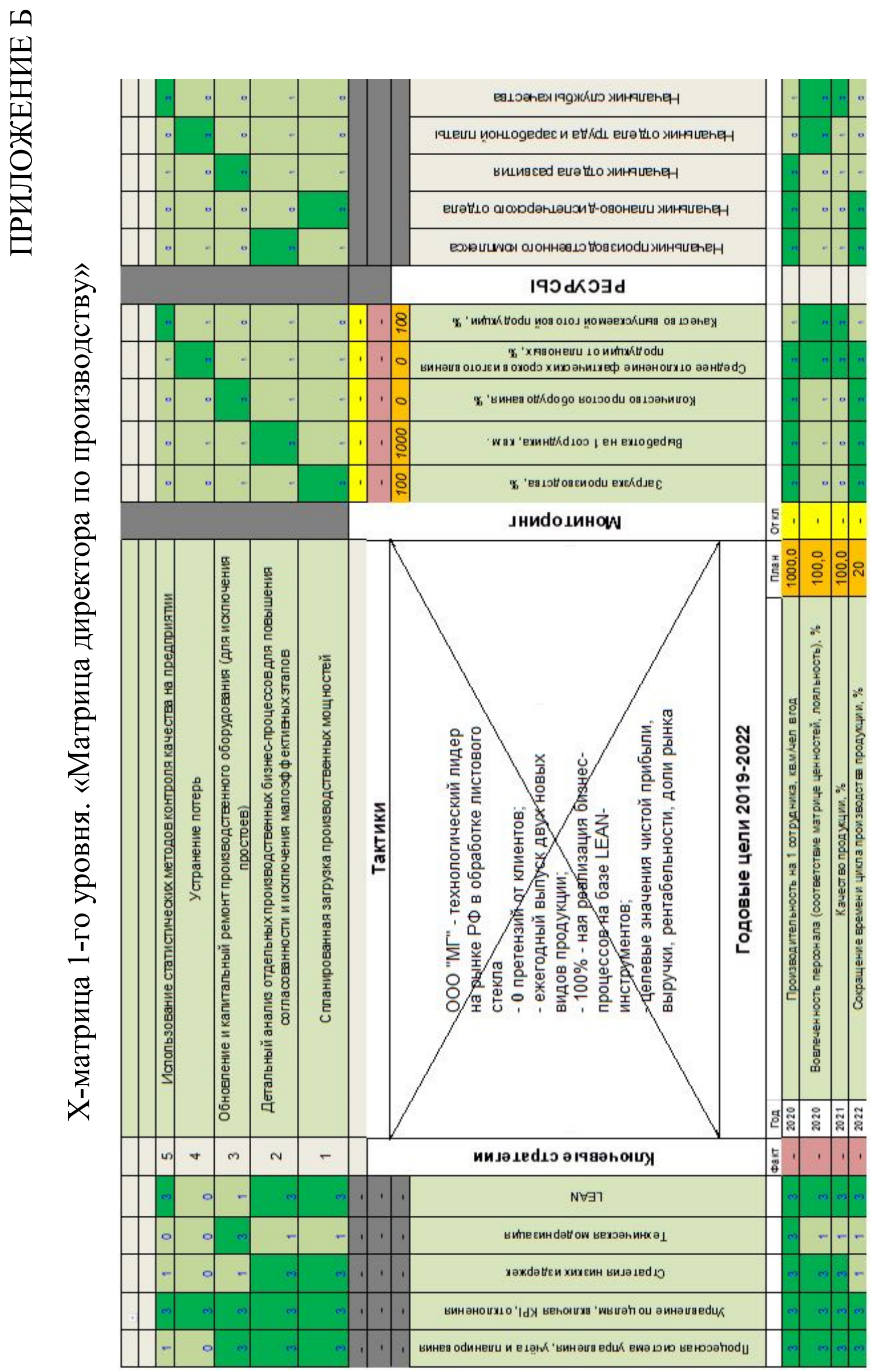




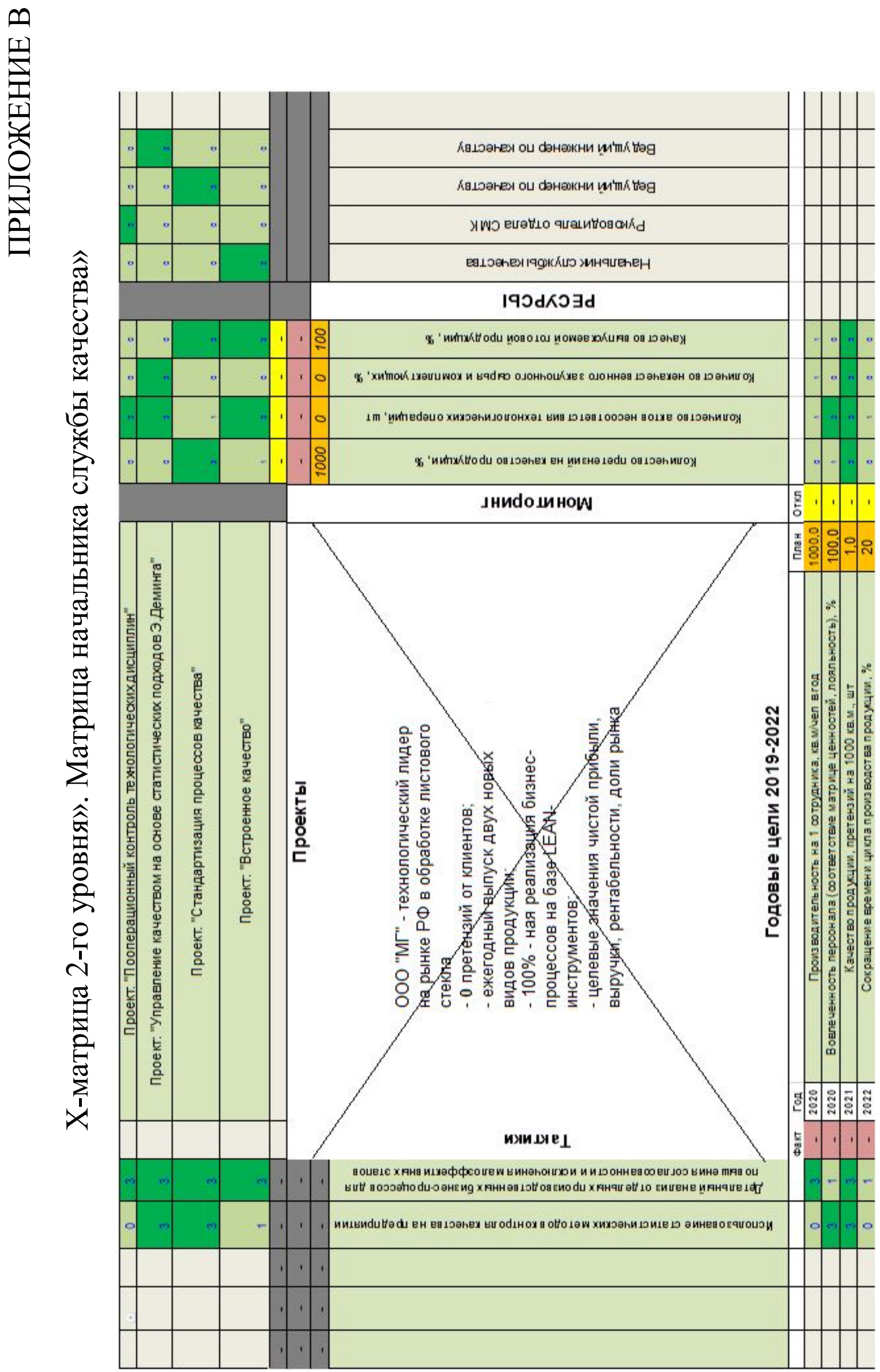





\section{СВЕДЕНИЯ ОБ АВТОРАХ:}

Кельчевская Наталья Рэмовна - заведующий кафедрой экономики и управления на металлургических и машиностроительных предприятиях ИнЭУ УрФУ, доктор экономических наук, профессор, Заслуженный работник Высшей школы РФ.

Слукина Светлана Александровна - доцент кафедры экономики и управления на металлургических и машиностроительных предприятиях ИнЭУ УрФУ, кандидат экономических наук, доцент.

Пелымская Ирина Сергеевна - доцент кафедры экономики и управления на металлургических и машиностроительных предприятиях ИнЭУ УрФУ, кандидат экономических наук, доцент.

Вольф Федор Валерьевич - доцент кафедры экономики и управления на металлургических и машиностроительных предприятиях ИнЭУ УрФУ, кандидат экономических наук, доцент. 
Научное издание

\author{
Кельчевская Наталья Рэмовна \\ Слукина Светлана Александровна \\ Пелымская Ирина Сергеевна \\ Вольф Федор Валерьевич
}

\title{
СОВЕРШЕНСТВОВАНИЕ СИСТЕМЫ УПРАВЛЕНИЯ БИЗНЕС-ПРОЦЕССАМИ СОЗДАНИЯ И ФУНКЦИОНИРОВАНИЯ МАЛОГО ИННОВАЦИОННОГО ПРЕДПРИЯТИЯ
}

\author{
монография
}

\author{
Выпускающий редактор Цветкова А.В. \\ Корректор Богданова Е.А. \\ Верстальщик Журавлева В.А.
}

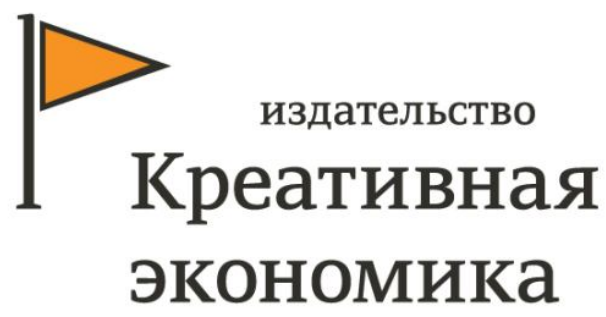

Усл. печ. л. 11,9. Тираж 500 экз.

Подписано в печать 27.11.2019

Формат: 60x84/16

Отпечатано ПАО «Т8 Издательские технологии» 109316 Москва, Волгоградский проспект, дом 42, корпус 5 Тел.: +7 (499) 322-38-30 